\begin{abstract}
Universidade de São Paulo
Faculdade de Economia, Administração e Contabilidade Departamento de Administração
\end{abstract}

\title{
Mecanismos de Regulação da Qualidade e Segurança em Alimentos
}


Reitor da Universidade de São Paulo

Prof. Dr. Adolpho Jose Melfi

Diretor da Faculdade de Economia, Administração e Contabilidade Profa. Dra. Maria Tereza Leme Fleury

Chefe do Departamento de Administração

Prof. Dr. Eduardo Pinheiro Gondin de Vasconcellos 


\title{
Universidade de São Paulo \\ Faculdade de Economia, Administração e Contabilidade Departamento de Administração
}

\section{Mecanismos de Regulação da Qualidade e Segurança em Alimentos}

\author{
Eduardo Eugênio Spers
}

Orientador: Prof. Dr. Decio Zylbersztajn

\begin{abstract}
Tese de doutorado apresentada à Faculdade de Economia, Administração e Contabilidade da Universidade de São Paulo, como requerimento para a obtenção do título de doutor em Administração.
\end{abstract}




\section{FICHA CATALOGRÁFICA}

Spers, Eduardo Eugênio

Mecanismos de regulação da qualidade e segurança em alimentos / Eduardo Eugênio Spers. -- São Paulo: FEA/ USP, 2003.

$136 \mathrm{p}$.

Tese - Doutorado

Bibliografia

1. Administração. 2. Regulação (Administração Pública). 3. Consumidores. 4. Estratégia. 5. Segurança dos alimentos. I. Faculdade de Economia, Administração e Contabilidade da USP.

$\mathrm{CDD}-658$ 
Este trabalho é dedicado à minha esposa Valéria e aos meus pais, Aleksandrs e Brigitte 


\section{AGRADECIMENTOS}

O trabalho de tese é marcado pela dedicação de várias pessoas que, diretamente ou indiretamente, contribuíram para a sua realização.

Ao Prof Dr. Décio Zylbersztajn, de quem pretendo levar os ensinamentos de mais de dez anos de convivência, como exemplo para a continuidade da minha carreira profissional, agradeço a paciência, dedicação e atenção, como orientador e amigo, na elaboração deste estudo. Meus agradecimentos estendem-se, também ao Prof. Dr. Sergio Lazzarini, que, teve uma participação direta tanto na formulação do modelo teórico quanto na metodologia de análise dos dados.

Agradeço à administradora de empresas Regina Azanha pelo apoio nas correções do documento. Ao coordenador do Banco de Dados da UNIMEP, Prof. Dr. Francisco Crocomo que cedeu o espaço para a realização das reuniões durante a pesquisa de campo. Aos alunos da UNIMEP, que, com rigor e empenho, me auxiliaram na condução da pesquisa de campo: Anderson Macario Ferraz, aluno do terceiro semestre do curso de propaganda e publicidade; Leandro Cardoso, aluno do quarto semestre de análise de sistemas, Fabrício Henrique de Oliveira, aluno do primeiro semestre de filosofia; Clayton Masquietto, aluno do nono semestre de economia, Ednalva Felix, Fábio J. Ribeiro de Oliveira, Solimar Guindo Messias e Fabíola C. Ribeiro de Oliveira, alunos do terceiro semestre de economia.

Agradeço ao Luis Felipe dos Anjos pela sistematização do banco de dados, à Profa Graciema Therezo pela revisão gramatical, à Profa. Sueli Leme pela revisão das normas gráficas e ao amigo Carlos Estevão Leite Cardoso, pesquisador da EMBRAPA, pelo auxílio na análise dos dados e compreensão do modelo.

Agradeço, ainda, o suporte financeiro fornecido pelo PENSA para a pesquisa de campo e pelo CNPq ao longo de todo o processo de doutoramento.

Agradeço aos que colaboraram indiretamente, à minha esposa Valéria Rueda Elias Spers, professora da UNIMEP, que, juntamente com a realização de seu trabalho de tese, dedicouse e foi companheira nas decisões e atividades desenvolvidas. Aos meus pais pelo apoio e estímulo ao meu trabalho. À minha irmã Cristina e ao meu tio Jevgenys a acolhida nas estadias em São Paulo. 
Agradeço aos amigos e companheiros do PENSA de São Paulo e de Ribeirão Preto que, embora mais distantes, contribuíram com a amizade e estímulo necessário para a realização deste trabalho. Aos alunos e colegas professores do IBMEC e UNIMEP, instituições em que pude conciliar a realização deste trabalho com as atividades de docência. Por fim, agradeço a FEA e aos colegas de pós-graduação e professores, com quem tive a oportunidade de interagir e aprender. 


\section{APRESENTAÇÃO}

Este trabalho foi elaborado para ser submetido à defesa junto ao programa de doutoramento em Administração da Faculdade de Economia, Administração e Contabilidade da Universidade de São Paulo (FEA/USP). O assunto da segurança e da qualidade do alimento vem sendo estudado pelo autor desde o estágio profissionalizante do curso de graduação em engenharia agronômica, em que um trabalho de pesquisa exploratório foi desenvolvido (SPERS, 1993), junto ao Programa de Estudos dos Negócios do Sistema Agroalimentar da Fundação Instituto de Administração da Universidade de São Paulo (PENSA, 2002) em 1992 sob a orientação do Prof. Dr. Décio Zylbersztajn.

O tema foi objeto de estudo durante curso realizado na França no Institut de Gestion Agroalimentaire (IGIA) em 1995 (SPERS e CHADDAD, 1996) e na dissertação de mestrado desenvolvida junto à Escola Superior de Agricultura Luiz de Queiroz (SPERS, 1998), na área de Economia Aplicada, pela aplicação de uma pesquisa junto a consumidores para avaliar a percepção da importância dos atributos de segurança do alimento. Em 1999 (SPERS e ZYLBERSZTAJN), foi realizado um estudo de caso na Austrália sobre um sistema de certificação público e privado sobre a qualidade e segurança em alimentos. 


\section{SUMÁRIO}

Página

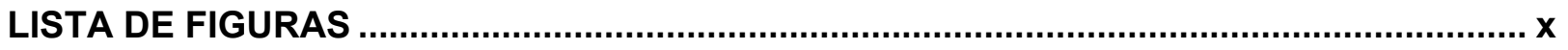

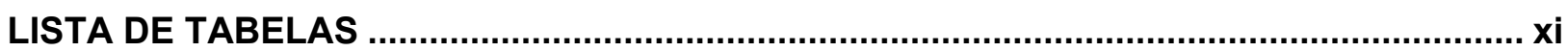

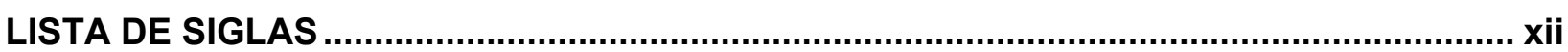

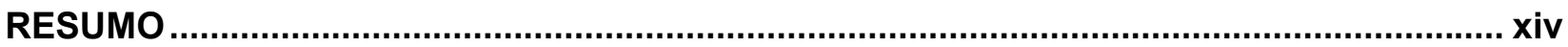

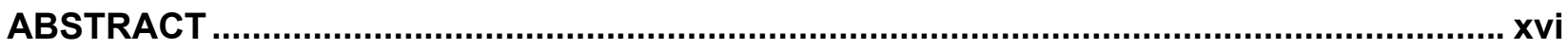

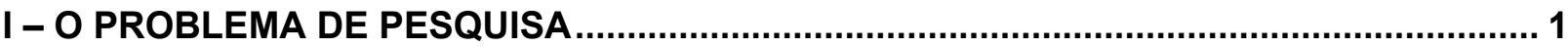

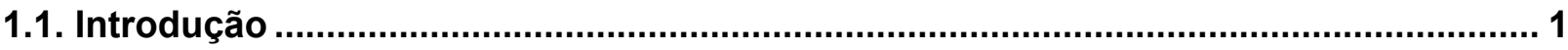

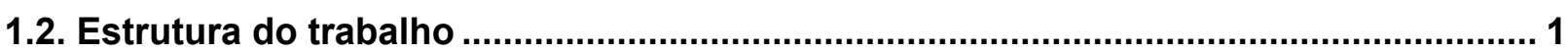

1.3. Formulação da situação problema ......................................................................... 2

1.4. Justificativa e importância do tema de pesquisa ....................................................... 6

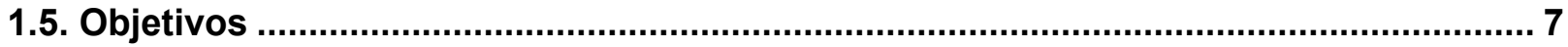

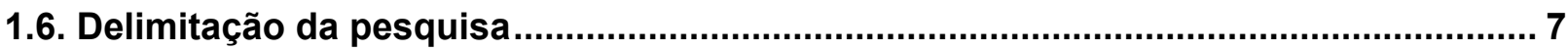

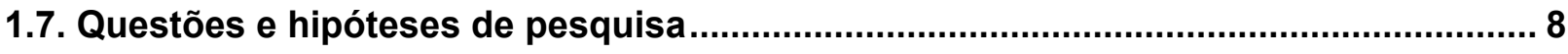

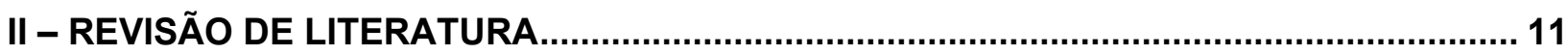

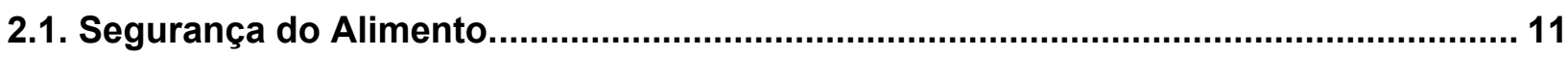

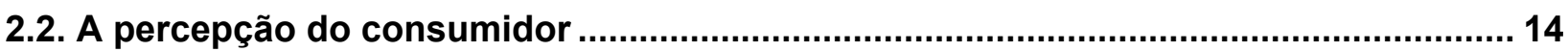

2.3. Consumo e segurança do alimento no setor de carne bovina .................................... 18

2.4. Arranjo institucional da segurança e qualidade do alimento...................................... 20

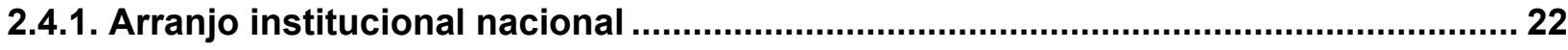

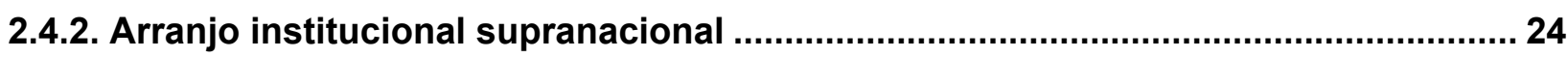

2.4.3. Arranjo institucional em outros países ................................................................. 25

2.5. Coordenação vertical e economia dos custos de transação ....................................... 32

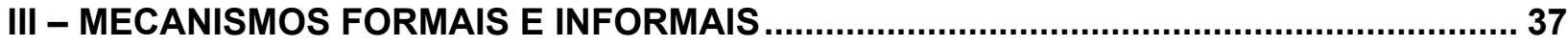

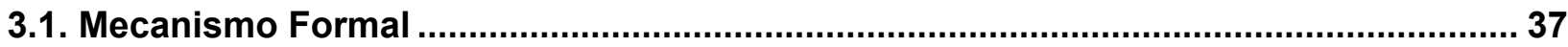

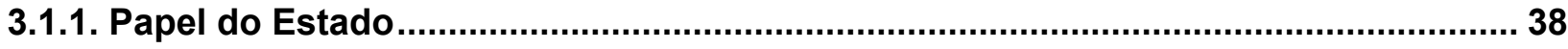

3.1.2. Oferta de direito de propriedade pública ............................................................... 40

3.1.3. Assimetria informacional e racionalidade limitada .................................................. 42

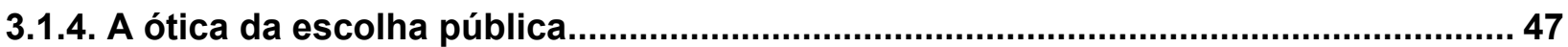

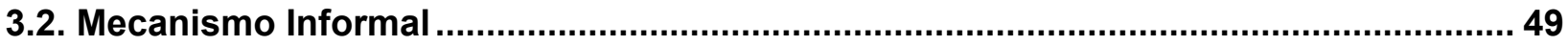

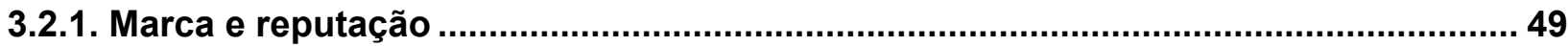

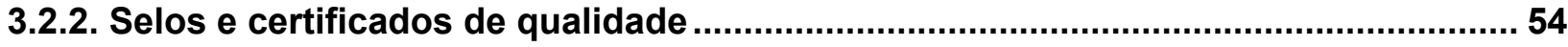




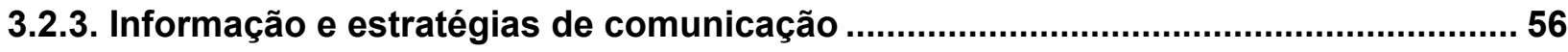

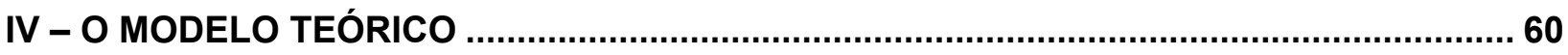

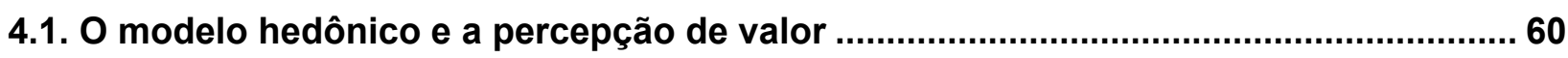

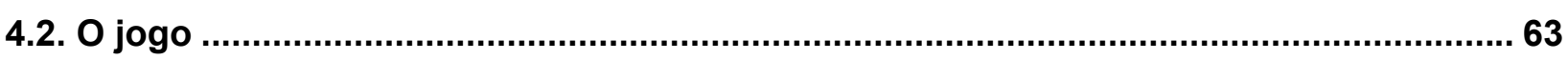

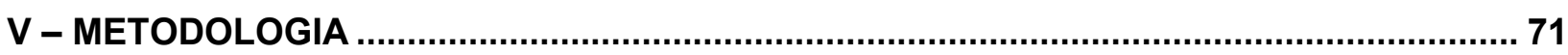

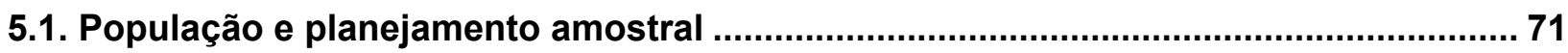

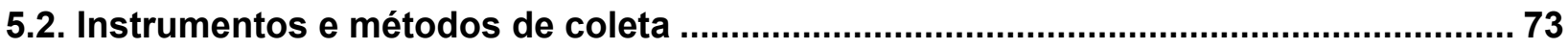

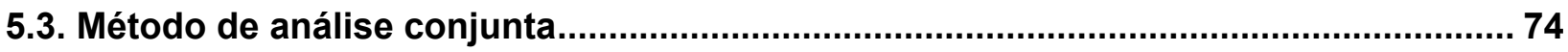

5.4. Método de análise: os modelos de regressão ordered probit e poisson..................... 78

VI - RESULTADOS E DISCUSSÃO ................................................................................. 82

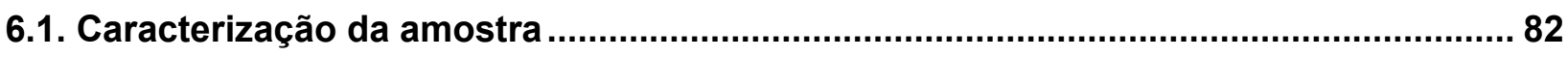

6.2. Comportamento em relação ao consumo de carne ................................................... 83

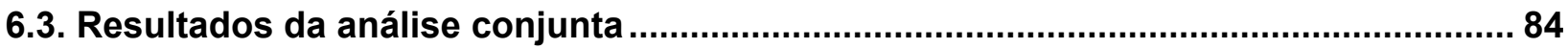

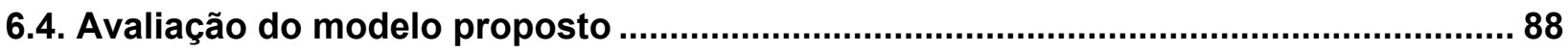

6.5. Resultados da entrevista com os agentes privados ................................................. 91

6.6. Resultados da entrevista com o órgão regulador ..................................................... 95

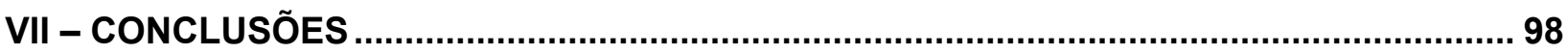

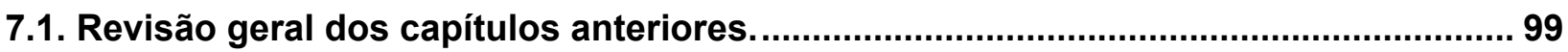

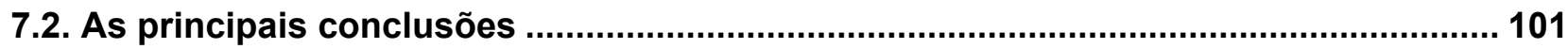

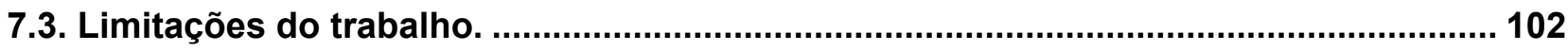

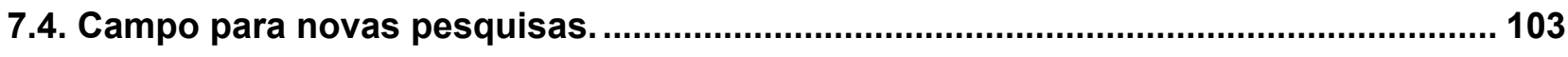

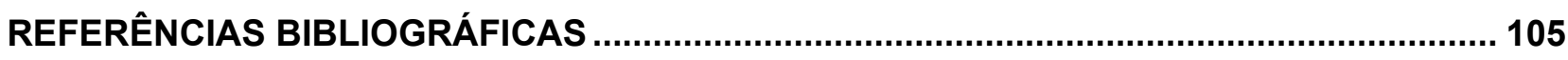

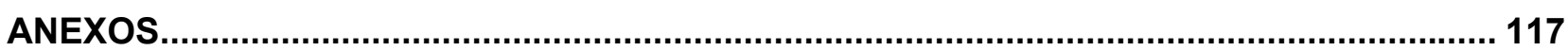

A - Legislações e regulamentos sobre segurança e qualidade dos alimentos..................117

B - Agências Federais Norte Americanas com funções de segurança do alimento.......... 118

C - Modelos de comunicação sobre saúde......................................................................... 119

D - Divisão do município de Piracicaba em regiões.......................................................... 120

E - Informações sobre o procedimento de amostragem................................................ 121

F - Questionário aplicado aos consumidores.................................................................. 122

G - Questionário aplicado aos agentes privados: açougues e supermercados. ............... 123

H - Índices de preços de carnes de média e alta qualidade em supermercados de

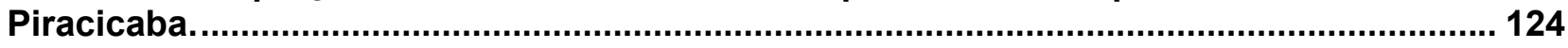

I - Cartões mostrados ao consumidor para ordenação. .................................................... 125

J - Caracterização do entrevistado ................................................................................. 127

K - Comportamento do entrevistado em relação ao consumo de carne............................ 128 
L - Sintaxe utilizada no SAS e STATA para a análise do modelo. .................................... 129

M - Resultados da análise entre marca e fiscalização ....................................................... 130

N - Resultados da análise entre preço e fiscalização....................................................... 131

0 - Respostas dos agentes privados às questões fechadas ............................................ 132

P - Ações privadas e públicas sugeridas pelos estabelecimentos ................................... 133

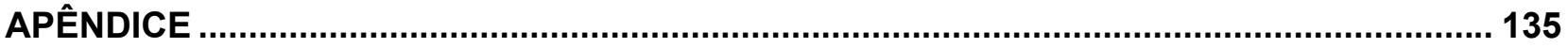

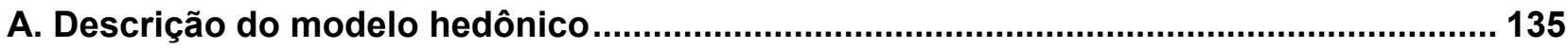




\section{LISTA DE FIGURAS}

Página

Figura 1. O modelo da qualidade total alimentar......................................................... 17

Figura 2. Interação entre arranjo institucional, indivíduo e governança ....................... 21

Figura 3. Organizações responsáveis em nível mundial ............................................... 25

Figura 4. Oferta e demanda por níveis de segurança do alimento ................................ 42

Figura 5. Percepção de valor do produto i em função da combinação de atributos .... 61

Figura 6. Custos do produto i em função da combinação de atributos ..........................62

Figura 7. Payoff entre empresa "E" e consumidor " $C$ " ................................................. 64

Figura 8. Payoff entre empresa "E" e consumidor "C" na presença de um órgão

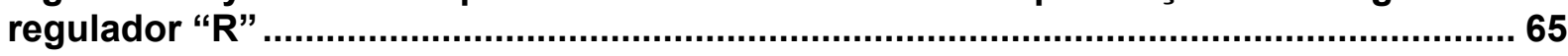

Figura 9. Equilíbrio para $Z_{i}=1 / 2$, de acordo com diferentes níveis de $\mathrm{F}$ e $\delta \ldots \ldots \ldots \ldots \ldots \ldots . . . . . . . .67$

Figura 10. Equilíbrio para $\delta=1 / 2$, de acordo com diferentes níveis de $\mathrm{F}$ e $(1-\mathrm{Z}) \ldots \ldots \ldots . . . . .68$

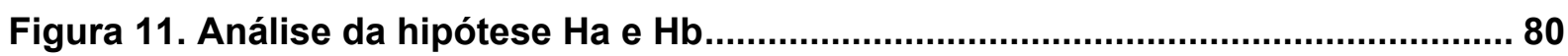

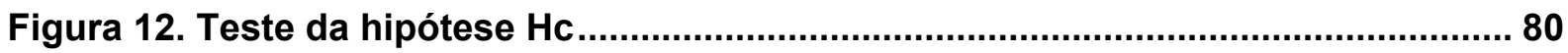

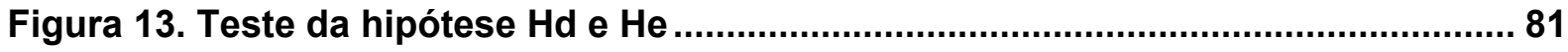

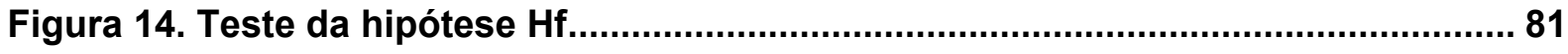

Figura 15. Importância geral em relação aos atributos, preço, marca e fiscalização ... 85

Figura 16. Preferência pelos níveis do atributo intensidade da fiscalização ................. 86

Figura 17. Preferência pelos níveis do atributo conhecimento sobre a marca .............. 86

Figura 18. Preferência pelos níveis do atributo preço .................................................... 87

Figura 19. Coeficientes da regressão entre marca e fiscalização ................................. 89

Figura 20. Coeficientes da regressão entre preço e fiscalização .................................... 90

Figura 21. Maximização da utilidade por atributos ...................................................... 136 


\section{LISTA DE TABELAS}

Página

Tabela 1. Agências reguladoras Norte Americanas. 26

Tabela 2. 0 papel da informação nas áreas de psicologia e marketing .......................... 58

Tabela 3. Fatores referentes como indicadores de qualidade ...................................... 75

Tabela 4. Atributos e seus respectivos níveis definidos para a análise conjunta ........ 77

Tabela 5. Importância geral dos atributos em relação às características do respondente

Tabela 6. Modelo de tabulação para a análise de ordered probit e Poisson para o consumidor "001" 88 


\section{LISTA DE SIGLAS}

ABIA - Associação Brasileira das Indústrias de Alimentos

ABIC - Associação Brasileira das Indústrias de Café

ABIEC - Associação Brasileira das Indústrias Exportadoras de Carnes

ANVISA - Agência Nacional de Vigilância Sanitária

APPCC (HACCP) - Análise dos Pontos Críticos e Controle (Hazard Analisys Control Critical Point)

BPF - Boas Práticas de Fabricação

BSE - "mal da vaca louca" ou encefalopatia espongiforme bovina

CEAGESP - Companhia de Entrepostos e Armazéns de São Paulo

CFSAN - Center for Food Safety and Applied Nutrition

COFRAC - Comité Francés de Acreditación

SDA - Secretaria de Defesa Agropecuária

DEFRA - Department for Environment Food and Rural Affairs

DFA - Delegacia Federal de Agricultura

DIPOA - Departamento de Inspeção de Produtos de Origem Animal

EMA - Entidad Mexicana de Acreditación

EUA - Estados Unidos da América

FAO - Food Aid Organization

FDA - Food and Drug Administration

FSIS - Food Safety Inspection Service

IAF - Institut de Apelation Francais

IB - Instituto Biológico de São Paulo

IBGE - Instituto Brasileiro de Geografia e Estatística

IBOC - Instituto de Orientação ao Consumidor

IDEC - Instituto de Defesa do Consumidor

INMETRO - Instituto Nacional de Metrologia

ISO - International Organization of Standartization

MARA - Ministério da Agricultura, Pecuária e Abastecimento

MHS - Meat Hygiene Service

MLC - Meat Livestock Commission

NASA - North American Space Agency

$\mathrm{NEI}$ - Nova Economia Institucional

NIID - National Institute of Infectious Diseases 
NZIFST - The New Zealand Institute of Food Science and Technology

OAA - Organismo Argentino de Acreditación

OGM - Organismo Geneticamente Modificado

OMC (WTO) - Organização Mundial do Comércio (World Trade Organization)

OMS (WHO) - Organização Mundial do Comércio (World Health Organization)

ONG - Organizações Não Governamentais

PAC - Política Agrícola Comum

PPHO - Procedimentos Padrão de Higiene Operacional

PROCON - Fundação Procon

QAP - Quality Assurance Plan

SENAI - Serviço Nacional de Aprendizagem Profissional

SDA - Secretaria de Defesa Agropecuária

SIF - Serviço de Inspeção Federal

SISP - Serviço de Inspeção do Estado de São Paulo

SISBOV - Sistema Brasileiro de Identificação e Certificação de Origem Bovina e Bubalina

SPS - Sanitary and Phytossanitary Service

TQM - Total Quality Management

UE - União Européia 


\section{RESUMO}

Garantir a qualidade dos alimentos é um crescente objetivo dos governos, das companhias e dos agentes de padronização e certificação do comércio internacional. Seus esforços são direcionados a influenciar a percepção do consumidor quanto aos muitos atributos de um produto alimentar, com um cuidado particular em relação aos vinculados com a nutrição e segurança. A garantia da qualidade está ganhando em proeminência porque os atributos de qualidade estão sendo melhor monitorados por governantes, consumidores e companhias. Essa melhor avaliação sugere o aparecimento de garantias de qualidade voluntárias proporcionadas por companhias e de regulação pelo governo.

Os mecanismos formais e informais têm sido analisados separadamente na literatura sobre regulação e marketing. A análise da interação dos mecanismos proporciona visões conflitantes e extremas como a reputação sendo substituída pela regulação, nos casos em que exclusivamente a ação do estado é defendida como suficiente, e outra, em que a atuação do estado é desnecessária devido à confiança do consumidor na reputação da marca ou organização. Uma terceira visão ocorre quando a regulação é complementada com o uso de estratégias privadas de reputação sobre o produto ou organização e vice versa. O objetivo geral do trabalho é analisar essa relação de complementaridade ou substituição entre os mecanismos formais e informais relacionados à segurança do alimento com base na percepção do consumidor de carne bovina.

A pesquisa de campo foi conduzida com 591 consumidores do município de Piracicaba, Brasil, abordados em suas residências e nos estabelecimentos de comercialização de carne mais comuns, o açougue e o supermercado. Eles ordenaram os nove produtos hipotéticos em função de sua preferência por aqueles que proporcionam uma maior ou menor percepção de segurança e qualidade.

O modelo de análise proposto foi gerado a partir do modelo hedônico e do ferramental da teoria dos jogos. Nove produtos hipotéticos foram gerados a partir de uma matriz ortogonal de um conjunto de vinte e sete combinações possíveis de três intensidades diferentes, baixa, média e alta, de conhecimento sobre a marca (mecanismo informal), intensidade de fiscalização (mecanismo formal) e preço. 
Pela técnica de análise conjunta, a importância dada pelo consumidor para a intensidade de fiscalização foi de $42,05 \%$ e para a intensidade de conhecimento sobre a marca foi de $28,9 \%$. A ordem crescente de preferência para os níveis do atributo marca foi: "sem marca", "marca desconhecida" e "marca conhecida"; e para a fiscalização: "ausência de fiscalização", "fiscalização esporádica" e "fiscalização intensiva". A importância atribuída ao preço foi de $29,66 \%$. O nível médio foi o mais preferido $(R \$ 12,00)$, seguido pelo baixo ( $R \$$ $8,00)$ e alto $(R \$ 16,00)$. Essa menor preferência pelo nível de maior preço pode significar um trade-off a favor de um preço mais baixo e uma dissociação do atributo como elemento de percepção de alta qualidade. Apenas $7,1 \%$ dos entrevistados afirmam que o preço contribui para uma maior percepção da alta qualidade do produto, enquanto para a fiscalização intensiva a porcentagem foi de $73,6 \%$. Não foi possível identificar segmentos de consumidores com comportamentos e preferências distintas.

O modelo Ordered Probit e o modelo de regressão de Poisson foram utilizados para analisar a relação de complementaridade ou substituição. A análise de interação entre marca e fiscalização foi feita mantendo-se o preço constante. A percepção da qualidade do produto pelo consumidor é significativamente maior quando há um aumento concomitante da intensidade do conhecimento sobre a marca e da intensidade da fiscalização em relação a um aumento individual desses mecanismos. Também foi constatado que a complementaridade é significativamente maior de um nível baixo para um nível médio do que de um nível médio para um nível alto. No tocante à complementaridade entre preço e fiscalização, mantendo-se a intensidade de conhecimento sobre a marca constante, a complementaridade também foi constatada, embora sem significância no nível mais alto.

Foram sugeridas ações públicas e privadas que, utilizadas em conjunto, elevam a percepção de qualidade do consumidor em relação à carne comercializada. Devido ao pequeno escopo geográfico dos dados coletados, estudos mais aprofundados, em outras localidades, podem comprovar a complementaridade desses mecanismos e captar diferenças regionais. Aplicações deste modelo a outros problemas que envolvam estratégias privadas e públicas conjuntas, como a questão ambiental, também podem ser úteis. 


\begin{abstract}
The guarantee of the good quality of food is a growing focus of governments, companies and the international standardization, certification and trade agents. Their efforts are addressed to influence the consumer's perception over the many attributes of a food product, with special attention to the nutrition and safety attributes. The warranty of quality is overcoming in prominence because the attributes of quality are being better appraised by governments, consumers and companies. This better evaluation suggests the emersion of more proportionate voluntary quality warranties by companies and more regulation by the government.
\end{abstract}

The formal and informal mechanisms have been analyzed in general, separately on marketing and regulation literature. The analysis of the interaction among these mechanisms provides conflicting and extreme visions like the reputation being substituted by the regulation needs, in the cases where exclusively the action of the government is defended as enough, and other, where the performance of the state is unnecessary due to the consumer's trust in the reputation of the brand or organization. A third vision happens when the regulation is complemented with the use of private strategies of reputation on the product or organization and vice versa. The main goal of this study was to analyze the complementarity and substitution relationship between the formal and informal mechanisms related to food safety based on the bovine meat consumer's perception.

The model proposed was generated from the framework of game theory and of the hedonic demand analysis of attributes. Nine hypothetical products were generated starting from an orthogonal matrix of a group of twenty-seven possible combinations of three different intensities of knowledge on the brand (informal mechanism), monitoring (formal mechanism) and price.

The research was conducted with 591 consumers in the city of Piracicaba, Brazil. The consumers were interviewed in their residences and in the butchery and retail stores. They organized these hypothetical products in their order of preference on those that provide a higher or smaller perception of safety and quality.

Using the technique of conjoint analysis, the importance given by the consumer for the intensity of monitoring was of $42.05 \%$ and for the brand knowledge intensity was $28.9 \%$. The preference for the levels of these attributes was growing with their increase, the growing 
order preference was the levels "without brand", "less known brand" and "well known brand" and for the monitoring the "absence of monitoring", "eventual monitoring" and "intensive monitoring." The importance attributed to the price was $29.66 \%$. The medium level was the most favorite ( $R \$ 12.00)$, followed by the lower $(R \$ 8,00)$ and the higher $(R \$ 16,00)$. That could mean a trade-off in favor of a lower price and a dissociation of these attribute as an element of a high quality perception. Only $7.1 \%$ of the interviewees affirm that the price contributed to a higher perception of the high product quality while for the intensive monitoring was $73.6 \%$. It was not possible to identify consumers' segments with different behaviors and preferences.

The Ordered Probit model and the Poisson regression model were used to analyze the complementarity and substitution relationship. Between brand and monitoring, maintaining the price constant, the perception of the product quality by the consumer is significantly higher when there is a concomitant increase of the intensity of knowledge on the brand and on the intensity of the monitoring in relation to an exclusive increase of each those mechanisms. It was also verified that complementarity is significantly higher from a low level to a medium level than from a medium level to a high level. Concerning complementarity between price and monitoring, maintaining the intensity of knowledge about the constant brand, the complementarity was also verified but in a smaller level of significance.

Public policies and private strategies that improve the quality perception of the consumer's quality regarding meat consumption were suggested. Due to the small geographical scope of the data analyzed, other studies conducted in other places can prove the complementarity or not of those mechanisms, and capture regional differences. Applications of this model to other problems that involve private and public strategies combined, as the environmental issues, can be also useful. 


\section{I - O PROBLEMA DE PESQUISA}

\subsection{Introdução}

A qualidade, em geral, e os atributos de segurança do alimento, são importantes elementos para a tomada de decisão dos consumidores, para as estratégias privadas e para as políticas públicas. Dois mecanismos, usualmente vistos em separado na literatura, podem contribuir para a percepção da qualidade do produto por parte dos consumidores. De um lado, a regulação é defendida como necessária para controlar e corrigir as falhas de mercado e gerar maior confiança por parte do consumidor. Do outro, a imagem positiva da marca e a reputação da firma são reconhecidas como estratégias de adição de valor ao produto. Com recursos escassos, onde deve o Estado investir para gerar maiores incentivos à oferta de produtos de qualidade via legislação e fiscalização? De que maneira uma organização privada pode investir para divulgar a qualidade do seu produto e criar uma imagem positiva perante o seu consumidor? O uso concomitante dessas duas estratégias gera um benefício maior por meio de uma melhor percepção da qualidade do produto? Essas são algumas perguntas que este trabalho tenta responder por meio de uma aplicação empírica sobre o consumidor de carne bovina do município de Piracicaba.

\subsection{Estrutura do trabalho}

O trabalho está estruturado em sete capítulos. No primeiro, são apresentados o problema, os objetivos, as justificativas e as hipóteses da pesquisa. No capítulo dois, é realizada uma revisão da literatura sobre o problema da segurança do alimento. Nele, são abordados os 
principais conceitos, discutidas as perspectivas econômicas e de gestão, mapeado o arranjo institucional em âmbito nacional e internacional e, por fim, seus reflexos na coordenação vertical dos sistemas agroalimentares. No capítulo três, são discutidas as abordagens relacionadas aos incentivos à adoção dos mecanismos formais de regulação e os aspectos relacionados à adoção dos mecanismos informais pelas organizações por meio de suas estratégias privadas e coletivas de sinalização da qualidade do produto ao consumidor como as marcas, os selos ou certificados e a comunicação. No capítulo quatro, é proposto o modelo teórico baseado na percepção do consumidor quanto aos atributos de garantia da segurança e qualidade do alimento e no ferramental da teoria dos jogos. A metodologia do trabalho é apresentada no capítulo cinco. Os resultados gerais são apresentados e discutidos no capítulo seis e, por fim, no capítulo sete, as principais conclusões e sugestões.

\subsection{Formulação da situação problema}

Para North (1990, p. 4) as instituições são qualquer forma de restrição que os indivíduos definem para suas interações. Elas podem ser formais, como as leis, e informais como as convenções e os códigos de conduta. As trocas amparadas pela confiança são, comumente, vistas como substitutas para contratos complexos em transações interorganizacionais, enquanto uma perspectiva alternativa é que esses contratos formais e a função relacional de governança sejam vistos como complementares (POPPO e ZENGER, 2002, p. 707). Existem níveis diferentes de incentivos, tácita ou compulsoriamente, à adoção, por parte dos agentes econômicos, das normas e regulamentações. Implicações estratégicas surgem para as organizações privadas e para o Estado a partir do entendimento da lógica dos incentivos que levam à adoção destas normas e regulamentações.

Entender de que modo essas relações formais e informais interagem em termos de sua complementaridade ou de sua substituição é de fundamental importância (LAZZARINI et al, 2002 , p. 2). Os mecanismos formais, baseados na lei, e os informais, baseados na confiança, usualmente são analisados separadamente na literatura. Surgem visões conflitantes, como a reputação sendo substituída pela necessidade de regulamentação e a regulamentação sendo complementada pela reputação. Segundo Cohen (1998, p. 47), duas áreas de pesquisa destacam-se como importantes em relação ao cumprimento e à adequação das firmas a uma lei. Na primeira, a incorporação de normas sociais, a pressão 
da comunidade e a reputação ${ }^{1}$ da firma. Na segunda, a exploração dos incentivos internos que a organização possui para se adequar a essas leis. Este trabalho visa enfocar a primeira área e testar empiricamente, partindo da percepção do consumidor, a relação entre a adoção de mecanismos formais e informais ${ }^{2}$. Com isso, é possível propor ações para gerar bem estar à sociedade pela oferta de produtos com níveis adequados e desejados pelos consumidores de segurança e qualidade alimentar.

Garantir a qualidade dos alimentos é um crescente foco dos governos, companhias e dos agentes de padronização e comércio internacional. Seus esforços são direcionados a influenciar os muitos atributos de um produto alimentar, com um cuidado particular com os atributos de nutrição e segurança. A garantia da qualidade está ganhando em proeminência por que os atributos de qualidade estão sendo mais bem avaliados por governantes, consumidores e companhias. Essa maior avaliação sugere mais garantias de qualidade voluntárias proporcionadas por companhias e mais regulação pelo governo. (CASWELL, 1998, p. 409, tradução nossa).

O consumidor percebe a existência de determinado padrão de qualidade pela combinação de diferentes atributos. Alguns são sinalizados pelo monitoramento público e outros pela reputação proporcionada pela confiança e lealdade à marca, por exemplo. Em qual combinação, intensidade ou situação de percepção do consumidor os mecanismos formal e informal devem ser utilizados para que haja incentivos à oferta de produtos com qualidade? A resposta a essa questão pode permitir que os recursos privados e públicos sejam mais bem alocados.

Fatores como a pressão por mais regulamentação por parte dos consumidores surgem em função de sua baixa confiança nas instituições e de sua racionalidade limitada ao superestimar, subestimar ou não compreender determinados riscos e benefícios. Essa é uma das justificativas para este trabalho pautar-se no consumidor a fim de avaliar os mecanismos formais e informais, embora uma entrevista qualitativa junto aos agentes públicos e privados também seja realizada.

\footnotetext{
1 "O capital reputacional é aquela porção do valor de mercado da empresa que pode ser atribuída à percepção da firma como uma corporação de boa conduta no mercado" (PINHEIRO MACHADO, 2002, p. 60).

${ }^{2} \mathrm{O}$ conceito de informal, aqui utilizado, é diferente do conceito de clandestino ou "subsistema informal, que seria o produto resultante do abate não fiscalizado e/ou que não contribui com impostos, e que, portanto, de uma forma ou de outra, desrespeita aspectos do ambiente institucional (BÁNKUTI, 2002, p. 11)". Estamos, aqui, considerando o formal como os mecanismos estabelecidos pelo Estado como, por exemplo, as normas, a estrutura de fiscalização e a aplicação de multas e as informais como os mecanismos ou práticas estabelecidas pelas organizações privadas e coletivas como, por exemplo, a adoção de marca.
} 


\section{Mecanismo formal}

As instituições e regulamentos são atuantes e necessários para a decisão do consumidor e para um melhor desempenho econômico (SMITH e WHITE, 1999). O Estado está presente na economia, para garantir os direitos de propriedade e o cumprimento dos contratos (KLEIN e LEFFER, 1981, p. 615). Ele tem a função de garantir, por meio dos mecanismos formais da regulação, da inspeção e da punição, o cumprimento das atividades necessárias que permitem alcançar um nível de segurança imposto pela sociedade ${ }^{3}$. Ao estabelecer regulamentos e normas, dois tipos de custos incidem: o de "fazer cumprir" (enforcement) e o de monitorar. Portanto, para minimizar seus custos, deve decidir qual será a estrutura de governança ${ }^{4}$ (WILLIAMSON, 1996) que mais eficientemente ${ }^{5}$, ou a um menor custo de transação ${ }^{6}$ (WILLIAMSON, 1985, p. 1), faz com que essas normas sejam obedecidas pela sociedade, consumidores e empresas privadas.

É crescente o surgimento de mecanismos formais relacionados à segurança do alimento (Anexo A). Entre as tendências futuras, estão as que definem regras para a rotulagem dos produtos, limites mínimos e máximos de vitaminas e minerais, uso de aditivos, presença de resíduos e contaminantes, estrutura de fiscalização, criação de agências reguladoras e instauração de processos judiciais (TURNER, 2000, p. 43).

As novas tecnologias e demandas também incentivam a elaboração desses mecanismos formais. Aspectos comerciais, como a existência de barreiras não tarifárias, exigem a definição e a adoção de normas que regulamentem, por exemplo, as práticas de controle do processo de produção e conservação de alimentos ou que identifiquem a origem do produto como a rastreabilidade em bovinos que, no caso nacional, é definido pelo Sistema Brasileiro de Identificação e Certificação de Origem Bovina e Bubalina (SISBOV).

\footnotetext{
${ }^{3}$ A sociedade também pode desempenhar a função de monitoramento na medida em que se organiza por meio de organizações não governamentais como as de defesa dos consumidores.

${ }^{4}$ Segundo Williamson (1996, p. 11), "governança também é um exercício em acessar a eficácia dos modos (meios) alternativos da organização. Uma estrutura de governança é, portanto, um pensamento útil de uma estrutura institucional na qual a integridade de uma transação ou um relacionado grupo de transações são decididas".

${ }^{5}$ Para uma discussão mais aprofundada sobre eficiência vide Mercuro e Medema, Chapter 4: Institutional Law and Economics: The Problematic Nature of Efficiency, 1997, p. 118-121.

6 "O custo de transação ocorre quando uma mercadoria ou serviço é transferido por meio de uma interface tecnologicamente sepadara (WILLIAMSON, 1985, p. 1)".
} 
Torna-se necessário definir normas, regulamentos e instrumentos de inspeção no mercado, devido à presença de assimetria informacional ${ }^{7}$ entre o comprador e o vendedor, como é o caso do Serviço de Inspeção Federal (SIF) para a carne ${ }^{8}$. No caso do consumo de alimentos, existe a dificuldade de se constatar muitos dos seus atributos intrínsecos de segurança como, por exemplo, a produção orgânica ${ }^{9}$ e a presença de resíduos não ou acima do tolerado. Além disso, pode não haver o consenso entre os consumidores, o Estado e as empresas privadas sobre quais deveriam ser os níveis de segurança do alimento.

\section{Mecanismo informal}

O problema da segurança e da qualidade assume importância sob o ponto de vista das organizações. A gestão da qualidade torna-se importante na medida em que existem custos, embora não facilmente mensuráveis, mas que afetam diretamente a rentabilidade das empresas de alimentos. Entre os prejuízos ocasionados por contaminações, estão a perda do produto, os custos de ações legais e indenizações aos consumidores, o desgaste da imagem da empresa e/ou marca do produto, o impacto negativo nas demais empresas que produzem ou comercializam produtos semelhantes, a perda de confiança do consumidor, os custos de uma administração de crise e, por fim, os investimentos necessários à recuperação da imagem da empresa.

As empresas alimentares vêm-se preocupando e investindo na gestão da qualidade de seus produtos. Além dos aspectos prejudiciais acima mencionados, destacamos alguns benefícios que incentivam esse investimento. Entre outros, o aumento da credibilidade do consumidor e dos fornecedores perante a empresa e seus produtos, a proteção à marca e a necessidade de sobreviver e crescer continuamente no mercado de alimentos, que é

\footnotetext{
${ }^{7}$ Segundo Akerlof (1970, p. 499), as instituições são formadas para garantir um mínimo de qualidade no produto devido a quantidade desigual de informação que o vendedor e o comprador possuem.

${ }^{8}$ O Serviço de Inspeção federal (SIF) para produtos de origem animal foi criado pela lei no. 1.283 de 18/12/1950 que atribui às esferas federal e estadual a tarefa de fiscalizar o abate e a industrialização da carne e outros produtos. Ela foi alterada em dois momentos. A primeira mudança ocorreu em 1971 pela lei no. 5.760, que delegou ao escopo federal a fiscalização. A última modificação ocorreu em 1989 pela lei no. 7.889 que estabeleceu as esferas federal, estadual e municipal como órgãos competentes para a fiscalização e inspeção. Nesta última alteração, somente as empresas registradas e inspecionadas em nível federal podem exportar e comercializar seus produtos entre os estados. As registradas em nível estadual podem comercializar dentro do estado e as registradas no município, somente dentro do município. Nem todos os municípios possuem o Serviço de Inspeção e os que possuíam, na sua maioria, o delegaram para o estado.
} 
altamente competitivo. Algumas evidências empíricas testam os efeitos positivos da comunicação com forma de sinalizar ao consumidor a maior qualidade do produto.

\subsection{Justificativa e importância do tema de pesquisa}

Em termos de originalidade ou inovação, o tema da segurança do alimento (food safety), apesar da sua importância, tem sido pouco explorado dentro da realidade nacional. O foco quantitativo ou segurança alimentar (food security) tem sido mais amplamente pesquisado devido à característica atual de desenvolvimento do país (SPERS, 1993, p. 19).

A originalidade na contribuição teórica justifica-se pela aplicação simultânea da teoria dos jogos e do modelo hedônico, pelo avanço teórico da administração no campo da gestão pública e da gestão do marketing e, por fim, pela visão de complementaridade ou de substituição dos mecanismos formais e informais, pois, em geral, suas funções dentro da administração e economia foram estudadas separadamente. O modelo aqui proposto pode ser aplicado a outras questões que envolvem assimetria informacional, percepção de atributos de qualidade e necessidade de ações públicas e privadas.

Em relação às pesquisas já realizadas, a importância pode ser evidenciada para a sociedade como um todo ao: a) propor elementos de incentivo à elevação do nível de segurança do alimento por intermédio de uma melhor estrutura de governança pública e privada e; b) aumentar a preocupação sobre o tema evidenciando a real percepção dos consumidores. Para a iniciativa privada: a) contribuir para as definições de mecanismos informais que visam aumentar a competitividade da indústria brasileira nacional frente às novas demandas e padrões internacionais; b) definir meios para proteger-se das barreiras não tarifárias e de entrada e; c) aproveitar melhor as vantagens comparativas com menores custos de produção e monitoramento. Para os tomadores de decisão públicos: a) auxiliar o Estado a definir estruturas de governança e políticas públicas de incentivo que permitam a aplicação mais eficiente dos mecanismos formais e; $\mathbf{b}$ ) avaliar ex-ante os possíveis impactos e conseqüências dessas políticas. Para as organizações públicas e privadas: contribuir para que adotem conjuntamente os mecanismos de regulação.

\footnotetext{
${ }^{9}$ Mesmo na produção de animais, o termo orgânico tem sido utilizado para descrever a produção sem o uso de qualquer tipo de produto químico (Primeira Conferência Virtual Global sobre Produção Orgânica de Bovinos de Corte).
} 
A viabilidade operacionaliza-se em termos de acesso e disponibilidade dos dados necessários à coleta e análise das informações de campo. Os dados para a aplicação e teste do modelo de pesquisa podem ser coletados por intermédio da pesquisa de campo junto aos consumidores de carne bovina. A caracterização do ambiente institucional formal é factível devido à divulgação pública das normas e da disponibilidade prévia dos agentes públicos e privados em fornecer as informações necessárias.

\subsection{Objetivos}

O objetivo geral do trabalho é testar, empiricamente, a relação de complementaridade ou substituição, em diferentes níveis, dos mecanismos formais e informais relacionados à segurança do alimento no segmento de carne bovina.

Os objetivos específicos são: testar empiricamente a relação de complementaridade ou substituição entre fiscalização e preço, caracterizar a estrutura do ambiente institucional formal internacional e nacional relacionado à segurança e à qualidade do alimento; caracterizar o comportamento do consumidor de carne bovina do município de Piracicaba, analisar e propor as estratégias privadas de sinalização de qualidade e de adequação aos mecanismos formais; descrever as estratégias e propor melhorias na escolha pública para a definição e estruturação dos mecanismos formais de regulação e inspeção.

\subsection{Delimitação da pesquisa}

O escopo da pesquisa está atrelado ao conceito de ambiente institucional e de seus mecanismos formais e informais de regulação sobre a segurança e a qualidade dos alimentos. Incentivos internos às organizações como a redução de custos advindos, por exemplo, do cumprimento das normas não serão abordados (COHEN, 1998, op cit). O foco da pesquisa empírica está calcado na percepção do consumidor em relação, especificamente, aos atributos de garantia da segurança e qualidade alimentar. A justificativa de se escolher alimentos como foco da pesquisa é atribuída ao fato de existir a necessidade de atuação dos dois mecanismos. Do Estado, pela existência de assimetria informacional em relação aos atributos de qualidade e da iniciativa privada pelas estratégias 
de adição de valor e diferenciação. A carne bovina foi escolhida devido a três fatores: (1) existência de problemas de baixa qualidade e perda de reputação perante o consumidor provocado pela doença da vaca louca e pelo uso de hormônios de crescimento; (2) forte presença do Estado na fiscalização e; (3) necessidade de adaptação das empresas a normas como a rastreabilidade e a investimentos em selos de qualidade e marcas próprias.

\subsection{Questões e hipóteses de pesquisa}

Entre as questões de pesquisa a que este estudo pretende responder, estão: a percepção, por parte do consumidor, da eficiência dos mecanismos de regulação formal e informal para garantir a qualidade do produto e os trade-offs ${ }^{10}$.em relação à marca, preço e fiscalização.

As hipóteses a serem testadas, neste trabalho, estão vinculadas ao modelo proposto no capítulo quatro. É razoável supor que o uso dos dois mecanismos, simultaneamente, eleve a percepção de qualidade do consumidor. Nesse caso, eles seriam complementares, ou seja, em conjunto, aumentariam a percepção da qualidade do produto. No caso de serem substitutos, aumentos dos níveis de mecanismo formal, por exemplo, reduziria o efeito de um aumento do mecanismo informal para gerar maior percepção da qualidade do produto pelo consumidor e vice-versa. Em outras palavras, quanto maior for a percepção quanto ao poder do fazer cumprir do mecanismo formal, ou seja, uma percepção positiva quanto à maior fiscalização (maior número de fiscais e maior valor da punição ou multa, por exemplo) menor a necessidade de se investir em um mecanismo informal como a marca.

Também foram formuladas hipóteses que testem os efeitos marginais decrescentes na percepção do consumidor à medida que os níveis dos mecanismos aumentam. A capacidade de o mecanismo evidenciar maior qualidade decresce em níveis mais altos. $O$ efeito da complementaridade tende a diminuir de intensidade quando os níveis de marca e fiscalização são altos.

As hipóteses a serem testadas neste trabalho são:

\footnotetext{
${ }^{10}$ Permuta. O consumidor deverá escolher sua preferência entre todas as variáveis ou atributos simultaneamente, ponderando qual é o mais importante no conjunto.
} 
$H_{A}$ : Os mecanismos formal e informal são complementares no aumento da percepção de qualidade do produto pelo consumidor de um nível baixo para médio de intensidade dessas variáveis.

$H_{B}$ : Os mecanismos formal e informal são complementares no aumento da percepção de qualidade do produto pelo consumidor de um nível médio para alto de intensidade dessas variáveis.

$H_{C}$ : Os incrementos marginais na percepção da qualidade do produto são menores à medida que as intensidades dos mecanismos formal e informal aumentam.

O efeito do preço e sua relação com a fiscalização também serão testados empiricamente:

$H_{D}$ : O mecanismo formal e o preço são complementares no aumento da percepção de qualidade do produto pelo consumidor de um nível baixo para médio de intensidade dessas variáveis.

$H_{E}$ : O mecanismo formal e o preço são complementares no aumento da percepção de qualidade do produto pelo consumidor de um nível médio para alto de intensidade dessas variáveis.

$H_{F}$ : Os incrementos marginais na percepção da qualidade do produto são menores à medida que as intensidades do mecanismo formal e do preço aumentam.

A percepção do consumidor pode variar em função de variáveis como o local (entre municípios e estados, por exemplo), idade, sexo, renda, tipo de entreposto de comercialização de carne bovina, entre outras. Caso ocorram variações, é possível identificar grupos de consumidores que tenham comportamentos semelhantes e, com isso, identificar e propor estruturas de mecanismos formais e informais diferentes que atendam às suas expectativas. Podemos, ainda, supor que produtos destinados a mercados e a clientes mais exigentes (como o mercado internacional dos países desenvolvidos, por exemplo) incentivam mais a adoção e a adaptação das organizações às normas, ou ainda, quanto maior a exigência ou percepção da qualidade do produto, por parte da sociedade, mais o valor adicional (preço prêmio) recebido pela adoção de mecanismos informais de reputação premia a organização com a expectativa de ganhos futuros em suas transações. 
A complexidade, (quantidade de regras, por exemplo), a mudança tecnológica necessária, o custo de adequação, a necessidade de contratar competências fora da organização, a origem, os interesses dos próprios agentes econômicos e a imposição do Estado podem ser consideradas como características do mecanismo formal ${ }^{11}$ (LEWINSOHN-ZAMIR, 1998). Estas considerações não serão testadas formalmente, mas serão levantadas por meio das entrevistas qualitativas com os agentes privados e públicos relacionados à formulação e à utilização dos mecanismos formais e informais.

\footnotetext{
${ }^{11}$ Lewinsohn-Zamir (1998, op. cit.), relaciona a diferença entre as estruturas de preferências de consumidores e cidadãos. Neste estudo, podemos argumentar, da mesma forma, que existem diferenças entre as preferências pelas normas que beneficiam o regulado e as normas que beneficiam terceiros ou a sociedade como um todo.
} 


\section{II - REVISÃO DE LITERATURA}

Este capítulo discorre sobre os principais conceitos, origem e importância do tema segurança do alimento bem como caracteriza o assunto no sistema agroindustrial da carne. Como o estudo se baseia na percepção do consumidor, uma revisão sobre seu comportamento quanto à qualidade do produto, mais especificamente alimentos, é apresentada. Também é discutida a importância e caracterizada a estrutura dos arranjos institucionais em diferentes níveis nos quais os mecanismos formais e informais estão presentes. Reflexos do problema da segurança na relação de coordenação dos agentes do sistema agroindustrial são apontados.

\subsection{Segurança do Alimento.}

Segundo Caswell et al. (1991, p. 4), para se avaliar economicamente a segurança do alimento sobre o sistema agroalimentar e as alternativas de estratégias públicas e privadas com relação ao problema, é preciso responder, a várias questões: quanta regulamentação os consumidores desejam; qual vai ser o impacto de se banirem um ou mais pesticidas, drogas animais ou aditivos alimentares; qual é o potencial de mercado para produtos irradiados, orgânicos ou transgênicos; quanto o consumidor está disposto a pagar por esses produtos; de que modo os consumidores respondem às propagandas de produtos alimentares que não causam danos à saúde e ao conteúdo informativo dos rótulos de embalagens; se um alimento contém um certo resíduo com risco à saúde, quem vai 
consumi-lo e em que nível de segurança; como o consumidor responde a informações sobre segurança e quais são as mais importantes.

A segurança do alimento vem sendo objeto de interesse por parte de diversos agentes econômicos, dos consumidores e de algumas organizações não governamentais (ONG), que surgem como agentes de pressão sobre o ambiente institucional, com a percepção de que existe a probabilidade de risco de prejuízo à sua saúde devido ao consumo de alimentos adulterados ou contaminados. Também do Estado, em função da necessidade de garantir o direito de propriedade do bem público, segurança no consumo de produtos alimentícios, por intermédio da eficiente utilização dos mecanismos formais. Por fim, das empresas privadas, que necessitam desenvolver ações individuais e coletivas de utilização de mecanismos informais, como a criação de marcas e selos que servem para se adequarem às pressões da sociedade e às normas estabelecidas pelo Estado, além de garantir ganhos adicionais com um prêmio recebido pelo produto ou pela garantia de recompra futura do produto condicionada, entre outras variáveis, à sua reputação.

É importante diferenciar os conceitos dos termos segurança alimentar e segurança do alimento. $O$ primeiro, sob o enfoque quantitativo (segurança alimentar) refere-se ao abastecimento adequado de uma determinada população ${ }^{12}$. Teixeira (1981), define segurança alimentar como "a segurança alimentar mínima alcançada quando os países em desenvolvimento chegam a uma produção de alimentos equivalente às suas próprias necessidades". Essa segurança pode ser obtida por meio do aumento da renda familiar, conjuntamente com uma oferta adequada de alimentos, via aumento da produção interna ou aumento das importações. Este termo é mais conhecido e amplamente discutido no Brasil ${ }^{13}$, pelo fato de ainda ser uma preocupação básica dos países em desenvolvimento, onde os problemas nutricionais básicos atingem grande parcela da população.

A segurança do alimento (enfoque qualitativo), ou seja, a garantia de o consumidor adquirir um alimento com atributos de qualidade que sejam do seu interesse, entre os quais se destacam os atributos ligados à sua saúde (SPERS, op. cit, 1993) tem crescido em

\footnotetext{
${ }^{12}$ Em 1974 a, Conferência Mundial da Alimentação celebrada em Roma pronunciou-se pelo estabelecimento da Vigilância Alimentaria e Nutricional (VAN) como a única forma de desenvolver os sistemas de informação relacionados com a nutrição com vistas a selecionar e aplicar políticas e programas efetivos para a população http://www.rlc.fao.org/redes/sisvan e http://www.usach.cl/sisvan/.

${ }^{13} \mathrm{Em} 2003$ o governo Brasileiro lançou o programa Fome Zero cujo objetivo é garantir a segurança alimentar (food security). Para mais detalhes vide: <http://www.fomezero.gov.br/ >. Acesso em 10 mar. 2003.
} 
importância, juntamente com os novos processos de industrialização e com as novas tendências de comportamento do consumidor.

Tanto o termo qualidade, como o termo segurança do alimento, apresentam diversas definições na literatura, devido, principalmente, à sua complexidade, à multidisciplinaridade, a diferenças culturais entre as regiões e sociedades, ao caráter dinâmico, aos diferentes pontos de vista entre comprador e vendedor e ao nível concorrencial e tecnológico (JURAN, 1992). A seguir, são listadas algumas das definições mais importantes:

\footnotetext{
"é a garantia em se consumir um alimento isento de resíduos que prejudiquem ou causem danos à saúde" (FAO). "É o inverso do risco alimentar - a probabilidade de não sofrer nenhum dano pelo consumo de um alimento" (HENSON e TRAILL, 1993, tradução nossa).

"aquisição, pelo consumidor, de alimentos de boa qualidade, livres de contaminantes de natureza química (pesticidas), biológica (organismos patogênicos), física (vidros e pedras), ou de qualquer outra substância que possa acarretar problemas à sua saúde" (HOBBS e KERR, 1992, tradução nossa).
"segurança não é uma mercadoria que os consumidores de alimentos podem ir ao supermercado para comprar... antes, segurança é uma característica das mercadorias e serviços que eles compram, e ela é uma característica extremamente cara e em alguns casos impossível de ser acessada" (SMITH, M. E. et al., 1998, tradução nossa).

Essa última definição reflete a dificuldade que se tem em garantir a segurança de um produto. Em alguns casos, produzir um alimento com determinado padrão de segurança esbarra no alto custo, ou, ainda, na presença de características associadas indesejáveis como dureza, superfície de dano e coloração inadequada.

Na língua portuguesa, segurança significa a condição daquele ou daquilo em que se pode confiar. Portanto, a segurança alimentar está relacionada à confiança do consumidor em receber uma quantidade suficiente de alimentos para a sua sobrevivência, ou do país em poder fornecer essa quantidade, enquanto segurança do alimento significa a confiança do consumidor em receber um alimento que não cause riscos à sua saúde.

"Segurança do alimento", também, refere-se a uma alimentação saudável, rica em vegetais e frutas. Segundo Frazão (1995), "entre duas pessoas que não fumem e que não bebam excessivamente, o fator de maior influência no aumento da expectativa de vida é o que comem". Nos países industrializados, embora os meios de comunicação prefiram dar maior ênfase às doenças como o câncer e às desordens coronárias, as doenças relacionadas com 
a alimentação assumem papel de destaque, sendo que, entre as dez maiores causas de morte nos Estados Unidos, quatro estão relacionadas aos alimentos, perfazendo, juntas, mais que $50 \%$ dos casos (FRAZÃO, op. cit.). Nos países em desenvolvimento, além de causar elevado número de mortes, eles contribuem significativamente para o agravamento dos problemas nutricionais.

Para atender aos anseios nutricionais do consumidor, surgem os alimentos denominados nutracêuticos ou alimentos funcionais que, segundo Jonas e Beckmann (1998), "são uma categoria de alimentos na qual os produtos são, ao mesmo tempo, (a) modificados ou (b) fortificados com substâncias que têm um efeito preventivo ou terapêutico inserido no seu valor nutricional original". A legislação brasileira, atualmente em vigor, exige a comprovação científica desses alimentos funcionais com o intuito de proteger o consumidor (BRASIL, 2001).

As substâncias usadas no tratamento e na alimentação dos animais causam preocupação, já que algumas delas, por eles ingeridas podem ser, posteriormente, transmitidas ao homem através da carne contaminada (HALBRENDT et al., 1991). Para que um nível tolerável de resíduos fármacos permaneça no corpo dos animais, estudos científicos definem normas que estabelecem a quantidade máxima de produto a ser utilizada.

Entre os principais fatores que influenciam e culminaram no aumento da exigência por atributos de segurança nos alimentos, por parte dos consumidores, do governo e das instituições privadas, pela segurança e pela gestão da qualidade de alimentos, estão a industrialização e a urbanização, o aumento da competitividade, o desenvolvimento da pesquisa científica, a diminuição da renda gasta com alimentação, a globalização e as mudanças e novas demandas dos consumidores.

\subsection{A percepção do consumidor}

Perante o consumidor, o segmento de produção e industrialização de alimentos tem passado por crescentes e sucessivas crises de credibilidade, medo e insegurança devido a acusações de contaminações e adulterações em seus produtos. Outros fatores que contribuem para a desconfiança e pouca compreensão por parte do consumidor são os crescentes desenvolvimentos obtidos no processamento e engenharia genética, a constante 
introdução de características intangíveis que são pouco percebidas, ingredientes e características funcionais. Embora tragam benefícios tanto para o produtor quanto para o consumidor, alguns consumidores e organizações não governamentais (ONGs) acreditam que essas tecnologias possam ser muito perigosas se mais intensamente exploradas.

A comunicação entre o sistema produtor/distribuidor e o consumidor final torna-se mais dinâmica e complexa. No caso de alimentos, o envolvimento e a demanda de informações por parte do consumidor é alta, já que se trata de produto consumido diariamente e sujeito a constantes mudanças, tanto no seu processo de produção quanto no de sua conservação. A utilização de técnicas de bioengenharia genética para a produção de organismos geneticamente modificados, por exemplo, provocam a falta de compreensão e a desconfiança por parte dos consumidores, os quais, em muitos casos, superestimam seus efeitos. A percepção de risco pode ser "socialmente construída". O risco percebido como involuntário e não natural é maior comparado com aquele em que as pessoas percebem que possuem uma escolha, mesmo se a probabilidade de tal risco é pequena.

Soma-se a esse fato a desconfiança com relação ao papel do estado na garantia do direito à saúde e ao consumo de alimentos saudáveis, que foi agravada na Europa com a crise da "vaca louca". Algumas indústrias e distribuidores de alimentos tentam elevar a sua confiança do consumidor por meio da não produção ou não comercialização de produtos geneticamente modificados, por exemplo. Algumas empresas são acusadas de não informar adequadamente o consumidor sobre seus avanços científicos e os respectivos riscos associados, criando uma percepção negativa e uma antipatia por suas ações e produtos.

Todos esses fatores culminam na necessidade de as organizações agroalimentares entenderem o comportamento do consumidor com relação às informações e, com isso, adotarem estratégias adequadas de comunicação com o seu público alvo.

Os modelos usuais de análise de demanda assumem que os consumidores conhecem e entendem os riscos associados ao consumo de alimentos e que expressam as suas preferências e avaliações dos diferentes níveis de segurança alimentar fazendo uma efetiva escolha entre produtos que oferecem uma variedade de riscos e probabilidades de ocorrência. A presença de assimetria de informação torna esses modelos inadequados para explicar o fenômeno. 
Podemos assumir a relação Consumidor-Empresa como um contrato (FOXALL, 1999). Nesse caso, a assimetria de informação permite a ocorrência de ação oportunística por parte do mercado. Como exemplo, um agricultor ou uma indústria alimentar, na intenção de diferenciar seu produto, atingir novos nichos de mercado e aumentar o valor do seu produto, pode alegar que ele é produzido sem aditivos, pesticidas ou agrotóxicos. Por não ser visualizada externamente e, muitas vezes, por falta de metodologias apropriadas, de laboratórios especializados, ou devido ao elevado custo, a veracidade da informação não pode ser constatada.

Na compra de alimentos, uma grande parte das dimensões de qualidade não podem ser verificadas antes da compra. Essas dimensões são denominadas características ou atributos intrínsecos do produto, como a ausência de aditivos e conservantes, ausência de resíduos químicos e valor nutritivo. Já a aparência, a cor, o tamanho e o formato são considerados atributos extrínsecos, porém nem sempre suficientes para avaliar as características de segurança e qualidade do produto. No entanto, para que os consumidores decidam comprá-lo, eles precisam formar expectativas claras em relação à sua qualidade. Nesse sentido, os mecanismos formal e informal podem colaborar para uma melhor percepção e, portanto, uma melhor avaliação das alternativas de produtos pelo consumidor. A percepção da qualidade do alimento também ocorre após a sua compra, preparo e consumo (GRUNERT, 2002, p. 2, Figura 1).

Vários trabalhos exploram o comportamento do consumidor com relação ao consumo de alimentos. Exemplos mais comuns são os que exploram a aceitação, a preferência, o desejo de pagar (willingness-to-pay) e as percepções sobre determinados atributos.

Grunert et. al. (2000), exploram a percepção do consumidor com relação ao consumo de três tipos de alimentos geneticamente e não-geneticamente modificados em quatro diferentes países nórdicos europeus. Utilizando-se da abordagem "significado-fim" (meansend) (GUTMAN, 1982), na qual a crença é organizada na estrutura cognitiva do consumidor. Grunert (op. cit, p. 2), explica que a abordagem significado-fim:

assume que a estrutura cognitiva consumo-relevância é organizada em cadeias que ligam a percepção concreta do atributo do produto com a conseqüência relevante pessoal e, ultimamente, com o atendimento aos valores da vida. Portanto, essa abordagem mostra como a percepção dos objetos no ambiente (produtos) está relacionada com as motivações básicas (valores de vida). 
O método utilizado para mensurar esta cadeia foi o de laddering (escada) por meio de entrevistas qualitativas. Nesse método, são gerados, primeiramente, atributos do produto; em seguida, realiza-se uma inferência de como esses atributos estão ligados às conseqüências relevantes pessoais e aos valores de vida presentes na mente do consumidor.

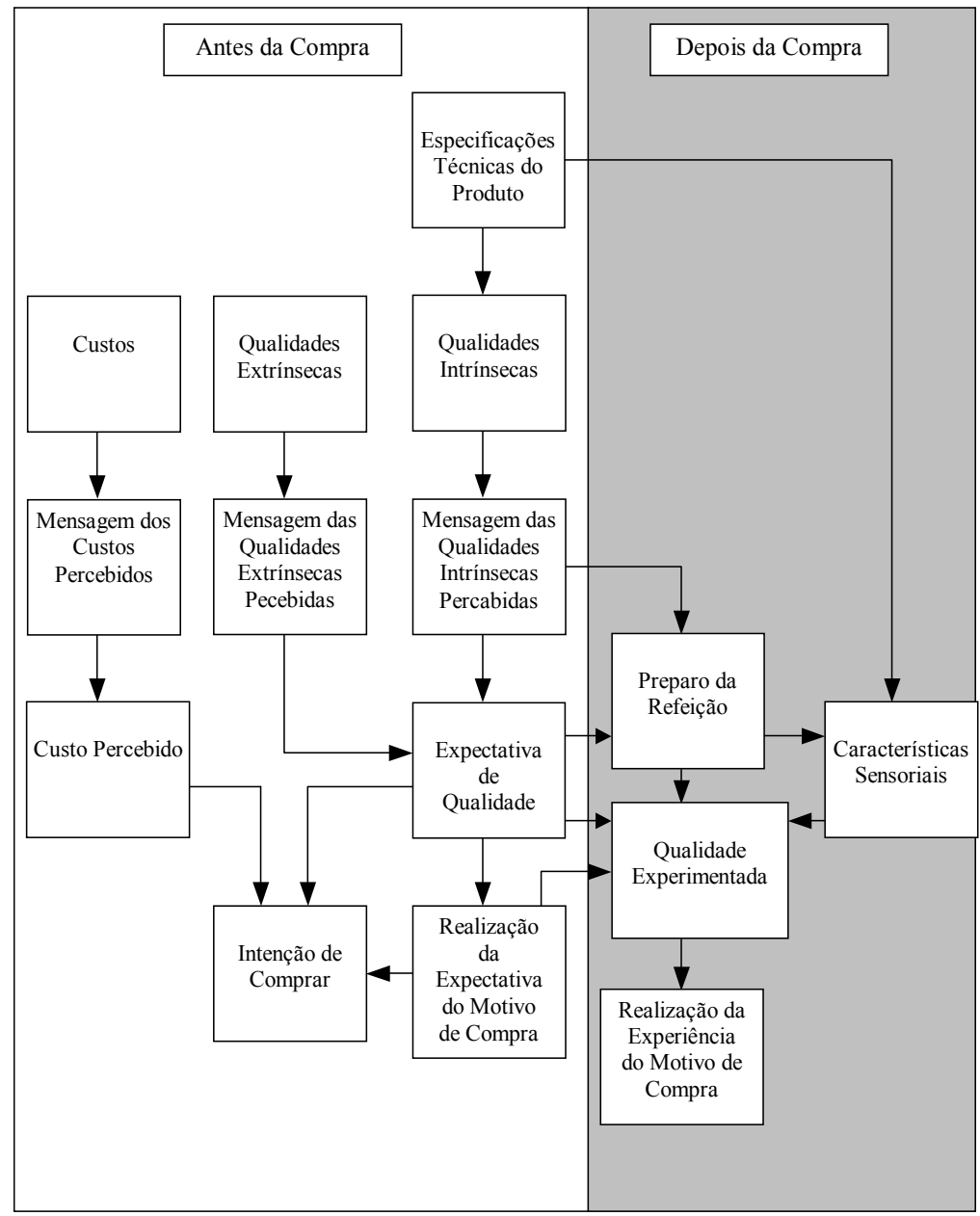

Fonte: GRUNERT, et al, 1996.

Figura 1. O modelo da qualidade total alimentar.

Mesmo nas nações economicamente desenvolvidas, com mais acesso à higiene e tecnologias sofisticadas, a preocupação é acentuada. Um dos episódios que abalou mercados na Europa, o "mal da vaca louca", minou a confiança dos consumidores. Em estudo conduzido pelo World Monitor Research (FMI, 2002), para indianos (71\%), russos (71\%), árabes $(70 \%)$ e filipinos $(70 \%)$, cuja desconfiança sobre o que comem ainda é grande, ocorreu diminuição da dúvida sobre a qualidade dos alimentos. As populações de 
Cingapura (47\%), Hong Kong (45\%), Austrália (40\%) e Estados Unidos (36\%) são as que consideram a comida de hoje mais segura do que há uma década. Entre os que alimentam a pesquisa de perda de fé no que vai para a mesa, a mulher dos países pesquisados percebe melhor do que os homens os efeitos, a longo prazo, de hábitos alimentares não saudáveis, em proporção de 52\% (das mulheres) para 41\% (dos homens). A pesquisa ainda revela que os idosos são os mais preocupados com doenças causadas por má alimentação: na Europa Ocidental, metade das pessoas acima dos 55 anos acredita que a comida se tornou menos segura e essa porcentagem sobe para $62 \%$ entre idosos no Oriente Médio e África. A amostragem dá conta, ainda, de que, entre indivíduos mais pobres, também há uma consideração maior sobre o aumento desses riscos na última década. Essa discrepância é mais acentuada na América do Norte (12\%), Europa Ocidental (18\%) e, especialmente, no Leste Europeu (21\%).

Vários são os fatores que influenciam o comportamento de compra do consumidor. Entre elas as variáveis pessoais, sociais, culturais e psicológicas. A confiança na ciência, nos sistemas regulatórios e no provedor da informação também influencia o comportamento do consumidor. Organizações não governamentais como as do Instituto Brasileiro de Orientação ao Consumidor (IBOC, 2003), que fornece informações específicas sobre o consumo de carne bovina, surgem como iniciativas de investimento na educação e informação do consumidor.

Assim como ocorre com outros produtos, também existe a percepção do risco no consumo, de alimentos. Essa percepção está relacionada tanto a suas características positivas como negativas. Os alimentos podem tanto combater e prevenir certas doenças (alimentos funcionais), como provocar doenças (no caso das salmonelas), até mesmo o câncer, e intoxicações (pesticidas e aditivos alimentares). Além disso, podem causar impactos no meio ambiente (alimentos geneticamente modificados).

\subsection{Consumo e segurança do alimento no setor de carne bovina}

O Brasil tem-se transformado no maior detentor de rebanho comercial do Planeta, com aproximadamente 170 milhões de cabeças, sendo $80 \%$ destinadas ao corte ou produção de carne e 20 \% à produção de leite. Esses números só são inferiores aos da China, onde o 
rebanho bovino atinge 200 milhões (ABIEC, 2002). O setor de alimentos, incentivado pela conquista de novos mercados internacionais com produtos alimentares como a carne, segundo o Instituto brasileiro de Geografia e Estatística (IBGE, 2002), apresentou um crescimento acumulado de 2,9\% no primeiro semestre de 2002.

O problema fiscal na produção da carne no Brasil é relevante na medida em que a arrecadação de impostos sobre a carne é mais importante para alguns estados do que para outros. Isso faz com que empresas de capital aberto deixem de atuar no mercado devido à dificuldade de cumprir as normas fiscais. As margens estreitas resultantes desse mercado fazem com que operem em um limite pouco recomendável em relação aos impostos.

O Brasil encontra problemas na carne também em barreiras protecionistas. Os Estados Unidos e a União Européia, que são os principais compradores de carne brasileira (juntos representam $49 \%$ das importações), impõem restrições sob forma de barreiras não tarifárias, tarifárias e subsídios altíssimos a seus produtores, além de cotas limitando a exportação de outros países.

A carne é uma fonte de proteína e de importantes vitaminas como a tiamina, riboflavina, vitamina B6 e B12, além de minerais como o zinco e o ferro. Porém, se produzida e comercializada de maneira incorreta, pode provocar intoxicação alimentar e, conseqüentemente, perda de valor e reputação para o consumidor final.

O Brasil, por sua vez, ressalta o perfil saudável do gado nacional, "boi verde", solto no pasto e comendo capim, em contraposição às características associadas aos surtos de doenças que vêm ocorrendo em diversos países devido, muitas vezes, ao confinamento e ao uso de ração produzida com componentes de animais. Esses processos produtivos deram início ao aparecimento de doenças como o "mal da vaca louca" ou encefalopatia espongiforme bovina (BSE). Essa doença abre uma discussão sobre a efetividade do estado em garantir a segurança do consumidor" (ENRIQUEZ-CABOT e GOLDBERG, 1996).

No mercado brasileiro e mundial, existem diferentes segmentos de consumidores de carne bovina. Pode-se falar em desejo de conveniência, praticidade, funcionalidade, segurança do alimento, qualidade, certificação e adequação às normas. O consumo de carne bovina pelos brasileiros acompanha a disparidade de renda que existe, hoje, no País. As altas taxas de consumo, semelhantes às dos maiores consumidores mundiais, estão associadas ao grupo 
de pessoas de renda elevada (que corresponde a mais de $50 \mathrm{Kg}$ de carne, por habitante, ao ano). Já as camadas de baixa renda seguem os padrões de consumo do terceiro mundo, com menos de $10 \mathrm{Kg}$ de carne, por habitante, ao ano.

Os consumidores de carne bovina nos EUA percebem diferenças de sabor nas carnes e estariam dispostos a pagar um preço "premium" por essa diferença (SPRIGGS e ISAAC, 2001). Quando perguntado aos americanos o que eles valorizavam mais, o aspecto origem da carne foi um dos destaques da pesquisa. A questão da confiança nos varejistas e em suas marcas foi a mais destacada. Pesquisas feitas com consumidores europeus mostram o crescimento da necessidade de informação sobre o produto (origem, rastreabilidade ligado à sanidade da carne), dado que a preocupação desses consumidores com doenças em virtude de produto contaminado é alta (SPRIGGS e ISAAC, op. cit.).

Saab (1999) utilizou a análise conjunta e identificou a seguinte estrutura de preferência pelos atributos da carne: preço $(60,0 \%)$, embalagem $(20,0 \%)$, selo $(13,3 \%)$ e cor $(6,7 \%)$. Essa pesquisa mostra que a postura do consumidor brasileiro vem mudando, com o passar do tempo, surgindo, cada vez mais, segmentos de consumidores mais exigentes por atributos de qualidade.

\subsection{Arranjo institucional da segurança e qualidade do alimento}

Entender a dinâmica e o comportamento, em nível macro, dos agentes que caracterizam o ambiente institucional e, em nível micro, das estruturas de governança, é importante para as empresas de alimentos e organismos públicos, os quais necessitam tomar decisões e gerenciar a questão da qualidade e da segurança de seus produtos e políticas. Este capítulo pretende descrever o ambiente institucional em seus diversos níveis: nacional e supranacional. Essa caracterização é importante para entender os possíveis impactos do uso dos mecanismos formais e informais. A forma como esses mecanismos irão interagir é influenciada pelo arranjo institucional.

\footnotetext{
"As instituições na sociedade provêem as regras do jogo que determinam os incentivos aos indivíduos em se engajar no aumento, crescimento ou redistribuição das atividades. Instituições são formais e informais. Instituições formais são as leis e regulamentos de uma sociedade. Instituições informais são as normas e costumes de uma sociedade" (ALSTON, EGGERTSSON e NORTH, 1998, p. 92).
} 
Segundo North (1990), "o maior papel das instituições na sociedade é reduzir a incerteza, estabelecendo uma estável (porém não necessariamente eficiente) estrutura para interação humana". O ambiente institucional é definido como as regras que ditam as estratégias das organizações. No caso da segurança dos alimentos, entender a forma como este ambiente se estrutura é fundamental para traçar as estratégias públicas, privadas e coletivas que proporcionem um nível adequado, desejadas pela sociedade, principalmente pelos consumidores.

Dependendo da forma como está estruturado o ambiente institucional, existe uma competição desleal e, portanto, um desestímulo para quem proporciona um padrão superior em termos de qualidade e segurança em seus produtos, gerando altos custos para o governo e para as empresas. A implementação de processos certificados de garantia da qualidade e investimentos em marketing social e ético pode ocasionar mudanças de postura comportamentais do consumidor (ou, pelo menos, parte dele), o que geraria um ambiente de maior competitividade. Entra aí a importância da variável ética e da responsabilidade moral com seus clientes em um determinado ambiente institucional. Autores como Jensen et. al. (1998); Antle (2000); Bánkuti (2002) e Vinholis (2001), descrevem a influências do ambiente institucional sobre o sistema agroindustrial da carne bovina.

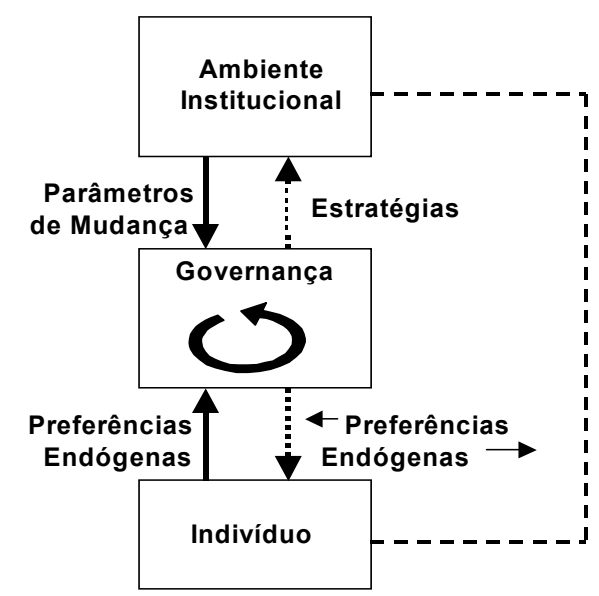

Fonte: WILLIAMSON, 1996, p. 223.

Figura 2. Interação entre arranjo institucional, indivíduo e governança

Por intermédio da Nova Economia Institucional (NEI), cuja primeira contribuição se dá pelo trabalho de Coase (1960) e do aprofundamento por vários autores, principalmente Williamson (1985 e 1996), é possível abordar tanto os aspectos micro, relacionados à teoria das organizações para a caracterização das estruturas de governança, como os aspectos 
denominados macro, relacionados ao ambiente institucional (Figura 2). Segundo Williamson (1996, p. 223), "a seta sólida define as interações primárias", ou seja, o ambiente institucional e o indivíduo definem a estrutura de governança. "Se mudanças ocorrem no direito de propriedade, leis de contrato, normas, costumes e gostos, induzem mudanças no custo comparativo de governança, então uma reconfiguração da organização econômica é geralmente incluída".

\subsubsection{Arranjo institucional nacional}

Do ponto de vista da saúde pública, no Brasil, o Ministério da Saúde, através da Vigilância Sanitária, atua no registro e na fiscalização de produtos alimentares. No Estado de São Paulo, o Instituto Adolpho Lutz, através de seu laboratório central, localizado em São Paulo, e os demais, em cidades do interior, é cadastrado como órgão oficial para realizar exames e emitir laudos, além de realizar, quando solicitado e quando possível, exames particulares. A falta de recursos humanos e laboratoriais dificulta a fiscalização, ficando sua realização restrita, apenas, aos casos de denúncias. Uma forma de melhorar o serviço seria o credenciamento de laboratórios para que também pudessem emitir laudos oficiais e, eventualmente, a auto-fiscalização em sistemas que se organizam para tanto. Nesse caso, se configura a substituição do formal pelo informal. A falta de recursos também não permite, após a aprovação de um produto alimentar, verificar se este está ou não obedecendo às suas características iniciais.

O sucesso da municipalização da fiscalização, ocorrida no Estado de São Paulo, depende do interesse e das condições de cada município (REZENDE, 1993). A fiscalização, na maioria dos municípios do Estado de São Paulo, é realizada somente no varejo. Pouco é executado no varejo e no atacado e, quase nada, nas indústrias.

É importante salientar a atuação das empresas privadas, principalmente as de grande porte, através da produção de alimentos de alta qualidade e da sua atuação como fiscalizadora ao longo do sistema agroindustrial, para ter certeza de que seu produto chegará com a qualidade desejada ao consumidor, sem contaminações que prejudiquem a imagem de sua marca. 
Na comercialização, pode ser citada a atuação da Companhia de Entrepostos e Armazéns de São Paulo (CEAGESP, 2003), que, em convênio firmado com o Instituto Biológico (INSTITUTO BIOLÓGICO, 2003), realiza exames para verificar os níveis de resíduos pesticidas presentes nos produtos por ela comercializados. Apesar desse esforço, não se consegue evitar que produtos contaminados sejam comercializados, pois o resultado do exame demora, em média, três dias e o produto não pode ser retido devido à sua perecibilidade.

Nas indústrias e nos supermercados, encontram-se os maiores problemas nos alimentos perecíveis, com contaminações microbiológicas, devido à refrigeração inadequada, ao alto tempo de exposição e às condições inadequadas de armazenagem e manipulação.

O governo não tem estrutura para atuar em todas as fases por que passa um produto até o consumidor. Melhorar a atuação da Vigilância Sanitária, nos pontos e fases críticas, desde a produção até a comercialização do alimento; orientar a atuação do produtor e, principalmente, das pequenas e médias empresas que não possuem um controle eficiente de qualidade, além de atuar de modo mais consistente durante a distribuição e a comercialização, são medidas que podem reduzir, sensivelmente, o problema da insegurança alimentar.

A falta de consciência e de informação por parte do produtor, por vezes, resulta no uso indiscriminado de pesticidas e de herbicidas, principalmente quando ele se vê ameaçado por uma praga, ou, mesmo, quando aplica tratos culturais corriqueiros.

No Ministério da Agricultura, Pecuária e Abastecimento - MARA (BRASIL, 2002a), junto à Secretaria de Defesa Agropecuária está vinculado o Departamento de Defesa Animal SDA/DDA (BRASIL, 2002b) ao qual competem várias atividades, entre elas zelar pela defesa sanitária animal. Na mesma secretaria, ao Departamento de Inspeção de Produtos de Origem Animal - DIPOA (BRASIL, 2002c) cabe a inspeção dos produtos de origem animal.Segundo a SDA:

\footnotetext{
"a fiscalização é a ação fiscal de verificação de estabelecimentos, produtos, matérias-primas, insumos e serviços, para garantir o cumprimento da legislação; a vigilância é a ação fiscal preventiva com foco nos seres vivos, promovendo e preservando a saúde dos vegetais e animais e a inspeção é a ação fiscal para a verificação de um estabelecimento, produto e sistemas de controle de produtos, matérias-primas, processamento e distribuição - com enfoque na preservação da saúde do consumidor e na garantia preventiva da conformidade dos produtos e processos, nos diversos elos das cadeias agroprodutivas e dos agronegócios".
} 
Criada em janeiro de 1999, a Agência Nacional de Vigilância Sanitária ANVISA (BRASIL, 2002d) é uma autarquia sob regime especial, ou seja, uma agência reguladora caracterizada pela independência administrativa, estabilidade de seus dirigentes durante o período de mandato e autonomia financeira. É vinculada ao Ministério da Saúde. Tem, como missão, "proteger e promover a saúde, garantindo a segurança sanitária de produtos e serviços". A finalidade institucional é a proteção da saúde da população através do controle sanitário da produção e da comercialização de produtos e serviços submetidos à vigilância sanitária, inclusive dos ambientes, dos processos, dos insumos e das tecnologias a eles relacionados. A Agência exerce controle de portos, aeroportos e fronteiras e a interlocução junto ao Ministério das Relações exteriores e instituições estrangeiras para tratar de assuntos internacionais na área de vigilância sanitária. Cuéllar (2001), explora o papel das agências reguladoras e Costa (1999) e Eduardo (1998), realizam um estudo histórico sobre o papel da Vigilância Sanitária no Brasil.

Existem diferenças entre o ambiente institucional brasileiro e o internacional. Além disso, organizações direcionadas a mercados internacionais sofrem diretamente um maior impacto do ambiente institucional global. Outras, porém, desenvolvem estratégias distintas para atingir clientes nacionais e internacionais.

Barreiras impostas a produtos nacionais, como ocorrido com o Canadá, reforçam a necessidade de adequações a estruturas e padrões internacionais. Dois argumentos surgem. O primeiro é por que uma organização voltada ao mercado interno tem tão poucos incentivos a investir em qualidade em comparação a outras direcionadas ao mercado internacional. Outro é a coerência ética de uma empresa que trabalha com dois padrões distintos de qualidade.

\subsubsection{Arranjo institucional supranacional}

Entre os organismos mais importantes estão a Organização Mundial do Comércio (OMC, 2002), a Organização Mundial da Saúde (OMS, 2002a) e, vinculada a ela, o Food Aid Organization FAO (OMS, 2002b), que é responsável pelo Codex Alimentarius (OMS, 2002c). 


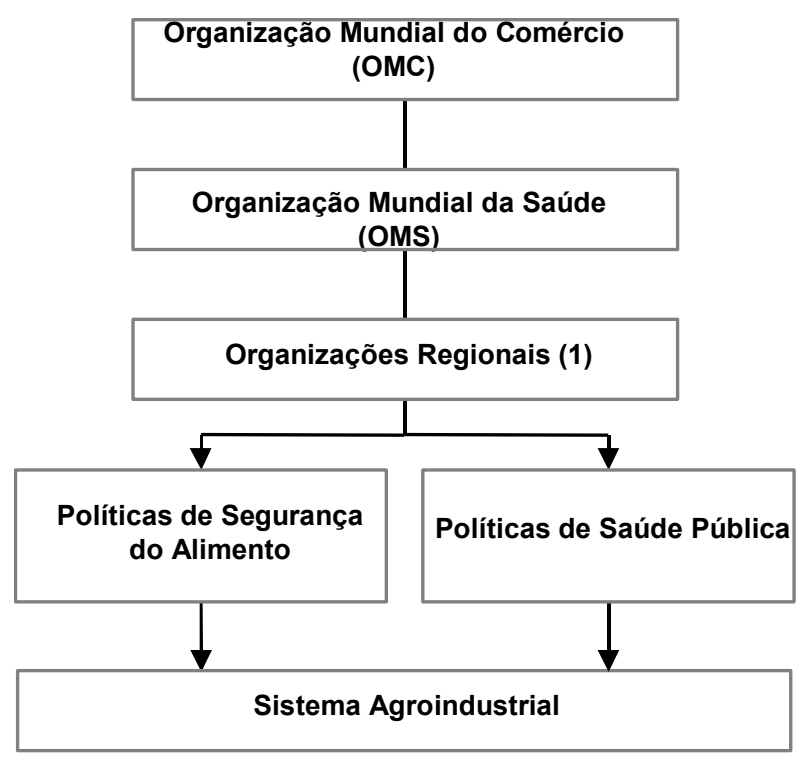

Figura 3. Organizações responsáveis em nível mundial

A Figura 3 mostra a interação entre as diferentes estruturas em seus respectivos níveis. As organizações supranacionais (1), como por exemplo o Parlamento Europeu, regula sobre as organizações nacionais como as agências nacionais de vigilância sanitária que, por sua vez, definem as suas políticas em nível estadual e municipal. Pela importância maior das questões comerciais, a OMC acaba sendo o órgão que possui a maior influência nas regulações supranacionais. Bergkamp (2001) e Unneverhr (2000) abordam as principais leis relacionadas aos alimentos e o seu impacto no ambiente institucional mundial.

\subsubsection{Arranjo institucional em outros países}

O intuito deste item é caracterizar, por meio de uma pesquisa exploratória e com dados secundários, as organizações e a estrutura relacionada à segurança do alimento em diferentes países.

\section{América do Norte e Canadá}

Schumann et. al. (1997) e Roberts (2001) realizam uma revisão das principais legislações pertinentes à segurança do alimento nos Estados Unidos. O Food and Drug Administration FDA (EUA, 2002a), do Ministério da Agricultura norte americano, aplica seu programa de 
segurança do alimento junto às organizações baseado nos procedimentos relacionados ao Hazard Analisys Control Critical Point (HACCP) ou Análise dos Pontos Críticos de Controle (APPCC). A Tabela 1 e o Anexo B mostram as principais agências Norte Americanas responsáveis, indiretamente ou diretamente, pela segurança do alimento. $O$ excessivo número de organizações é criticado e visto, por alguns autores, como uma ineficiência (HUNTER, 2001).

Tabela 1. Agências reguladoras Norte Americanas.

\begin{tabular}{|l|l|}
\hline \multicolumn{1}{|c|}{ Agência } & \multicolumn{1}{c|}{ Características } \\
\hline Federal Drug Administration & $\begin{array}{l}\text { A FDA foi instituída pelo Food and Drug Act de 1905. Seu objetivo é } \\
\text { proteger os consumidores contra alimentos e drogas que ofereçam } \\
\text { riscos. }\end{array}$ \\
\hline Federal Trade Commission & $\begin{array}{l}\text { A FTC foi criada em 1914. Seu propósito é evitar práticas comerciais } \\
\text { injustas e anticompetitivas. Este órgão também regula a propaganda } \\
\text { enganosa. }\end{array}$ \\
\hline $\begin{array}{l}\text { Consumer Product Safety } \\
\text { Commission }\end{array}$ & $\begin{array}{l}\text { A CPSC foi estabelecida em 1972 pelo Consumer Product Safety Act. A } \\
\text { agência é responsável por investigar as causas de acidentes } \\
\text { relacionados a produtos e estabelecer medidas corretivas. Essas } \\
\text { medidas podem incluir a devolução de produtos, a proibição de } \\
\text { comercialização de produtos perigosos, a exigência de devolução do } \\
\text { dinheiro e a determinação da obrigatoriedade de rótulos corretos e } \\
\text { instruções de segurança (como as encontradas nos aparelhos elétricos) }\end{array}$ \\
\hline $\begin{array}{l}\text { Environmental Protection } \\
\text { Agency }\end{array}$ & $\begin{array}{l}\text { A EPA foi estabelecida em 1970 para criar uma política nacional de } \\
\text { proteção do ambiente. }\end{array}$ \\
\hline
\end{tabular}

Fonte: Adaptado de SHETH, Jagdish. N. MITTAL, Banwari. NEWMAN, Bruce I. Contexto do Mercado: economia, Governo e Tecnologia. IN: Comportamento do cliente: indo além do comportamento do consumidor. São Paulo: Atlas, 2001. p.137.

Segundo Gattegno (1994, p. 126), o sistema HACCP, baseado no controle e no monitoramento dos pontos críticos, em que possa haver a contaminação do alimento, representa o futuro e a garantia da segurança no setor de alimentos. O Programa HACCP é uma tentativa de implementar, padronizar e avaliar programas de segurança alimentar. Tem a finalidade de prevenir potenciais riscos relacionados à segurança do alimento. Foi desenvolvido, na década de sessenta, por uma empresa privada e pela North American Space Agency (NASA), com a finalidade de prover alimentos seguros, que não acarretassem nenhuma doença aos astronautas, durante os vôos espaciais.

O programa HACCP (EUA, 2002b) contribui para os seguintes objetivos: aumentar a segurança do alimento, detectando a causa da doença ou morte biológica (bactérias e vírus), química (pesticidas e químicos sanitários), ou por contaminações físicas (vidros, pedras, madeira, entre outros); melhorar a qualidade de vida, favorecendo a produção de um produto saudável; por fim, evitar a fraude econômica, ocorrida através de ações ilegais ou dúbias, que podem enganar e confundir o consumidor, como a substituição de produto (de menor valor) ou incoerências de escalas (peso incorreto). 
Tradicionalmente, as indústrias e os órgãos fiscalizadores têm adotado a inspeção periódica das condições de processamento e a amostra aleatória para os produtos finais. Isso, porém, não tem funcionado como um tratamento preventivo. Por esse motivo, o FDA tem adotado o programa HACCP em muitos de seus códigos chamados de "Food Code", que servem de modelo para a legislação dos órgãos que licenciam e inspecionam os estabelecimentos nos Estados Unidos. Seus objetivos: identificar riscos e avaliar sua severidade; determinar o(s) ponto(s) crítico(s) de controle; estabelecer medidas de controle e critérios para garantir o controle, monitorar pontos críticos de controle e registrar dados, tomar atitude onde os resultados dos critérios de monitoramento indicarem e verificar se o sistema está funcionando como planejado.

Segundo o Center for Food Safety and Applied Nutrition - CFSAN (EUA, 2002c), as necessidades de implementação do programa estão relacionadas ao crescente aumento do número de novos patógenos, à crescente importância pública dada ao problema e ao aumento do tamanho das indústrias de alimentos.

\section{União Européia}

A Política da qualidade na Europa ${ }^{14}$ é uma tentativa de se neutralizar a estagnação da demanda de alimentos e aumentar o seu consumo, diferenciando-se estes pelas de características adicionais que são garantidas através de selos e certificados (SPERS e CHADDAD, 1996).

Ao contrário da Política Agrícola Comum (PAC), a competência da política sobre a qualidade de produtos não é transferida para a União Européia UE, que tem competência somente na mensuração de requisitos que possuem objetivos específicos.

Isso acarreta divergências que se tornam um obstáculo para a livre circulação de mercadorias. Nestes casos, a Comunidade se baseia nos artigos 100 e $100 \mathrm{~A}^{15}$. Em outros casos, ela aplica sua própria política de qualidade como a predominante, ou ainda, um instrumento complementar de sua política agrícola.

\footnotetext{
${ }^{14}$ Baseado na coleta de informações durante curso realizado no IGIA em 1995. O conteúdo das informações será atualizado durante a pesquisa de campo.

${ }^{15}$ Os artigos 100 e 100A referem-se à possibilidade da Comunidade de intervir sobre os Estados Membros para garantir o estabelecimento ou funcionamento do mercado comum.
} 
Em vista do princípio de subsidariedade ${ }^{16}$, a UE restringe sua atividade para a prescrição de regras uniformes que sejam válidas para todos. Com respeito à composição (receita) do alimento ou produto, os Estados Membros são livres para aplicar regras que considerem tradições e gostos locais.

Com o princípio do "mútuo reconhecimento", os Estados Membros são obrigados a admitir, em seu território, gêneros alimentícios que foram legalmente produzidos e comercializados em outros Estados Membros. A cerveja que contém aditivos, por exemplo, pode ser comercializada, na Alemanha, devidamente diferenciada, com informações na embalagem, apesar de o governo alemão considerar cerveja somente a bebida fermentada manufaturada exclusivamente através de cevada maltada, lúpulo, levedura e água sem nenhum aditivo ${ }^{17}$.

$\mathrm{Na}$ França, existem os queijos não pasteurizados. Estes podem ser comercializados sem problemas no país, mas não podem ser comercializados em outros países como a Holanda, que exige que o leite seja pasteurizado na fabricação do queijo. Os franceses vangloriam-se da quantidade dos microorganismos presentes nos seus melhores queijos, fato que causa repulsa nos consumidores mais ortodoxos dos países nórdicos.

O Guia do Consumidor Europeu funciona como o Código de Defesa do Consumidor (BRASIL, 1988) no Brasil. Diferentemente do Brasil, o consumidor europeu usa essas normas e diretrizes que o orientam com respeito a aspectos de qualidade e embalagem. Nele, são ressaltados os seguintes pontos. Nos produtos alimentares pré-embalados, a embalagem deve conter várias informações, sendo as mais importantes: o nome do produto; a lista de ingredientes; a quantidade liquida; a data limite de consumo ("consumir até..." para produtos perecíveis e "o consumidor deve de preferência a consumir até..." para os demais produtos); o modo como usar ou preparar o alimento. Outras informações também são obrigatórias, tais como as condições particulares de manipulação ou de preparação do alimento; as coordenadas do fabricante e/ou do vendedor; o local de proveniência ou de origem; as referências que permitam identificar o lote. A embalagem também deve advertir, quando for o caso, quando o produto é irradiado. Quando não há embalagem, a responsabilidade pelas informações cabe à autoridade de cada país.

\footnotetext{
${ }^{16}$ As instituições da Comunidade intervêm para resolver problemas de interesse da União como um todo, enquanto os Estados Membros regulam sobre problemas de interesse nacional.

17 "Lei da pureza" para cerveja.
} 
Em suma, a UE tem uma política cujo objetivo é promover um alto nível de garantia da saúde pública e, ao mesmo tempo, um correto e adequado esclarecimento do consumidor sobre a natureza, características e, se possível, origem dos produtos. Essa política de qualidade encoraja a diversificação da produção agroalimentar, garantindo o acesso do consumidor europeu a uma grande variedade de produtos e aumentando a renda do setor.

O controle da segurança e da qualidade dos alimentos tem uma longa história na França. Iniciou-se na escola de veterinária, por volta do ano de 1800, com, basicamente, duas finalidades. Primeiramente, a de suprir as tropas de Napoleão com alimentos de boa qualidade. Segundo, permitir aos veterinários apreender o alimento que não se apresentasse em bom estado de conservação ou fosse impróprio para o consumo.

Após a II Guerra Mundial, com o desenvolvimento da microbiologia por Pasteur, a noção de segurança veio a se relacionar com controle. O significado inicial era o controle em nível do mercado. Posteriormente, estendeu-se a todos os processos, desde o cultivo de produtos agrícolas até sua chegada ao consumidor final.

O aumento da qualidade também se deveu ao aparecimento de normas preocupadas em garantir um alto padrão de qualidade como o Total Quality Management (TQM), relacionado com todo o processo, desde o suprimento até o consumidor final. Esse sistema permite, entre outros: atingir metas que minimizem os custos (custos da não qualidade) e aumentar a eficiência do processo de produção; maximizar a renda a médio e longo prazo; consolidar o conhecimento tecnológico e o melhor ajuste da produção para as necessidades do mercado e das novas tecnologias.

O sistema agroalimentar francês está dividido, para fins de controle, basicamente entre os fornecedores e os consumidores de alimentos. O primeiro deve fornecer um alimento de boa qualidade, enquanto o segundo, cada vez mais, exige produtos com melhores atributos, entre eles, a segurança e a qualidade.

Os principais problemas no controle e monitoramento da segurança e da qualidade ocorrem na fazenda e no supermercado. Na indústria, o controle é feito por ela mesma, que tem interesse em produzir alimentos com alto padrão de qualidade que atendam o exigente consumidor europeu. Além disso, ela não quer correr o risco de ocorrência de um caso de contaminação que leve a credibilidade de sua marca a ser afetada. 
Em nível de produção rural, o controle é considerado forte. A preocupação iniciou-se com a evolução dos tratamentos e do uso excessivo de drogas no controle da saúde animal e do aumento do uso de pesticidas no controle de pragas e doenças vegetais.

As mudanças estão ocorrendo no sentido de se verificar, com mais rigor, como e qual pesticida está sendo usado, isto é, o controle é maior no processo de produção do que no produto final. Além disso, esses produtos perigosos entram em uma lista chamada de negra ou vermelha e não recebem subsídios da PAC (BIMA, 1994).

Há preocupação, também, com a alimentação animal. A ingestão pelos animais de alimentos com substâncias tóxicas para o homem pode deixar resíduos que, posteriormente, são transmitidos ao homem através do consumo de sua carne.

No supermercado, a temperatura e o tempo de exposição são alguns dos principais cuidados que se deve ter, além da criação de marcas e selos, que serão abordados neste trabalho juntamente com os mecanismos informais.

As intervenções nos estabelecimentos onde se verifica a contaminação são realizadas por um inspetor e são baseadas em um nível máximo tolerado. Esse nível pode ser o número de patógenos ou a quantidade de substância tóxica, ou, ainda, o número de vezes que um patógeno ou substância tóxica foi encontrada no alimento.

A questão que emerge é a de quem paga os dias em que a firma ou fazenda está parada e sem produção. Existem certos subsídios para casos como este e, também, seguros que remuneram o produtor no período em que ocorre a intervenção. No caso de cooperativas, a solução é o remanejamento do trabalho para outro local.

Devido a esse rigor, o trabalho do inspetor, às vezes, torna-se difícil. Os casos de suicídios de produtores que ficam desesperados por ter que parar a produção ou sentem remorso por terem causado uma doença ou até a morte de uma pessoa que consumiu seu alimento contaminado, são em torno de dois por ano e os casos em que há confronto armado ou ameaças a inspetores são em torno de cinco a dez por ano. Geralmente, as empresas de alimentos têm um seguro de qualidade.

Toda indústria de alimentos precisa elaborar um plano de garantia de qualidade Quality Assurance Plan (QAP) que é revisado periodicamente por um organismo governamental 
chamado "acreditation" que, também, tem a função de fiscalizar e credenciar laboratórios para a análise de alimentos. O "acreditation" também pode ser de outro país. O investimento inicial para a elaboração de um QAP é muito alto. Em alguns casos, e, principalmente, para as pequenas corporações, o custo chega a ser inviável, pois todo o processo de controle precisa ser escrito e fundamentado técnica e legalmente. Além disso, o processo precisa ser aprovado pelo órgão competente e implementado. Nos outros países da Comunidade Européia, o sistema é quase o mesmo com exceção do tipo de análise feita. Devido a esse rigoroso sistema, a criação de uma empresa no ramo de alimentação torna-se muito difícil. Isso acarreta problemas sociais como o agravamento da situação de desemprego no país.

Os laboratórios credenciados, que podem ser públicos ou privados, examinam o produto a cada processamento (MOREL, 1993). Um problema no controle pode ocorrer no resultado do exame da amostra que demora de cinco a oito dias. Depois desse período, o alimento já pode ter sido consumido, não se podendo fazer mais nada. Uma maneira de se evitar o problema é a melhoria das técnicas de laboratório e o monitoramento preventivo durante a produção rural e industrial.

Mesmo que haja o armazenamento inadequado dos produtos no varejo, isso é compensado pelo fato de o consumidor saber como preparar o alimento, ou seja, em pequenas porções e somente para o mesmo dia. Porém, esse procedimento pode não ser comum entre as pessoas mais jovens. Quanto à legislação de propaganda e marketing, não se podem fazer anúncios com relação à segurança alimentar, pois o produto já deve ser seguro.

Para os franceses e para os europeus de uma maneira geral, o ato de se alimentar é uma forma de celebração e de convivência social. Não é só o alimento, mas o processo de se alimentar, que leva em média duas horas. O europeu prefere fazer sua própria comida. Logo, a qualidade e a segurança alimentar é levada muito a sério.

No Reino Unido, o Department for Environment Food and Rural Affairs - DEFRA (REINO UNIDO, 2002a) regula sobre a higiene da carne e estabelece diretrizes para a produção, o fazer cumprir e as penalidades para a carne fresca, produção de produtos cárneos e para os picados de carne e seus preparados. Estas regulações são determinadas pela Food Standards Agency, tem como base o Food Safety Act de 1990 e Food Safety (General Food Hygiene) de 1995 e são inspecionadas por autoridades locais por meio de um Veterinário oficial do Meat Hygiene Service (MHS). Outras organizações importantes da Inglaterra são: 
o The Royal Institute of Public Health (REINO UNIDO, 2002b) e o Ukonline (REINO UNIDO, 2003) como fonte de informações oficiais.

\section{Austrália, Nova Zelândia e Japão}

A Austrália tem uma experiência de complementaridade entre mecanismo formal e o informal. Para aumentar a qualidade de seus produtos agroalimentares, o governo da oeste australiano, por intermédio da autoridade agrícola do estado, o AGWEST, desenvolveu um sistema público de certificação de qualidade que foi gradativamente sendo delegado à iniciativa privada. Quanto ao papel do governo:

o próprio AGWEST acredita que não deva conduzir a atividade no longo prazo. Algumas atividades já estão sendo realizadas por outros órgãos, como o registro dos facilitadores, que agora é função do Quality Society Australasia (QSA). A certificação propicia a mudança nas políticas nacionais de segurança do alimento, que passam das dispendiosas inspeções regulares para a certificação de qualidade de caráter mais preventivo (SPERS e ZYLBERSZTAJN, 1999, p. 7)

Os mercados internacionais mais importantes de carne bovina para a Austrália são o Japão, os Estados Unidos e a Coréia. O mercado japonês tende a ser mais preocupado com a qualidade. Para o Norte Americano a carne é destinada à posterior manufatura. Após a crise Asiática, a Austrália vem tentando atuar nos Estados Unidos, também, com produtos de qualidade. As principais mudanças que ocorreram no mercado australiano foram a adoção de padrões de segurança para o mercado externo (Sanitary and Phytossanitary - SPS) e o acordo da OMC (SPRIGGS e ISAAC, 2001, p. 108). Alguns órgãos relacionados à segurança do alimento são: Australia Food Science Centre (AUSTRÁLIA, 2002), AgriQuality (NOVA ZELÂNDIA, 2002a), The New Zealand Institute of Food Science and Technology NZIFST (NOVA ZELÂNDIA, 2002b) e National Institute of Infectious Diseases (JAPÃO, 2002).

\subsection{Coordenação vertical e economia dos custos de transação}

O conceito de agribusiness é "a soma total das operações de produção e distribuição de suprimentos agrícolas, das operações de produção nas unidades agrícolas, do 
armazenamento, processamento e distribuição dos produtos agrícolas e itens produzidos a partir deles" (DAVIS e GOLDBERG, 1957).

Dadas as características de qualidade, hoje empregadas, é necessária uma visão sistêmica, ou de agribusiness. Ao contrário da abordagem do problema da qualidade dentro de um segmento, ou na indústria, ou na agricultura, por exemplo, uma visão sistêmica é a somatória de ações desempenhadas pelos agentes, monitorados pelo governo e sob a pressão exercida pelos consumidores, que vai garantir a segurança. O sistema precisa estar devidamente coordenado e monitorado verticalmente (SPERS, op. cit, 1993).

Segundo Giandon (1994), para conseguirem o máximo de qualidade na produção de um alimento, as companhias mudaram progressivamente seu foco de atenção, antes baseada apenas na qualidade do produto, o que significava somente o controle do produto final. Posteriormente, a preocupação voltou-se para a qualidade do processo, que enfatiza o controle a cada ponto crítico da produção. Finalmente, a preocupação estendeu-se para a esfera sistêmica, a qual necessita da cooperação de todos os envolvidos no sistema agroindustrial, adquirindo fundamental importância para os seus agentes.

As mudanças que vêm ocorrendo no sistema agroalimentar e que são ditadas pelos consumidores, com sua exigência por alimentos com características de qualidade e de segurança, causam uma grande dúvida no setor quanto à estratégia adotada. Quanto irá custar e quem, (o governo, o setor privado, ou o consumidor) irá pagar por essas exigências? E quanto ao monitoramento e à adaptação dos vários pontos críticos do sistema? Será que o consumidor está preparado para arcar com os custos de um alimento seguro? Quais são as soluções e as ações no nível de todo o sistema agroalimentar?

A nova procura por produtos seguros farão com que se formem mercados cada vez mais exigentes, e a competitividade fará com que os sistemas reajam com rapidez e eficiência. Quanto maior a exigência ou a necessidade de se melhorar a qualidade dos produtos, maior será o incentivo à firma ou ao sistema agroalimentar para coordenar-se verticalmente, possibilitando um maior controle sobre as etapas pelas quais passa o alimento até o consumidor final. Este, através de sua exigência de atributos de qualidade e de segurança, transmite um fluxo de informação, sinalizado através dessa preferência, que segue em sentido contrário ao fluxo físico de produtos e serviços através do sistema agroalimentar. 
Programas de reengenharia, reestruturação e redimensionamento podem, nem sempre, resultar em um aumento da qualidade de um produto. Programas relacionados à qualidade total estão cada vez mais comuns nas empresas ligadas ao agribusiness. Contudo verificase que somente as que possuem incentivos à qualidade e que pertencem a sistemas altamente coordenados verticalmente usam essa metodologia.

O mesmo nível de segurança alimentar pode ser obtido com diferentes custos de transação". Esses custos de transação podem advir de ganhos na identificação do fornecedor, na negociação do contrato e na necessidade de verificação do contrato ou seu monitoramento.

Os custos de transação englobam todos os aspectos da relação contratual entre consumidores e fornecedores. Custos de se realizar trocas entre consumidores e fornecedores". (HOBBS e KERR, 1992). Alguns exemplos são os custos de monitoramento da qualidade do insumo do fornecedor e os custos de obtenção da informação a fim de encontrar um fornecedor ou insumo que atenda às especificações exigidas pelo comprador.

A governança refere-se à "matriz institucional na qual toda a transação é definida". Existem três formas de governança conhecidas: mercado clássico, contratos híbridos e hierarquia" (ZYLBERSZTAJN, 1995, p. 128). No caso da qualidade e da segurança, a empresa pode ter incentivos a internalizar ou integrar o seu controle (AUST, 1997).

Segundo Streeter et al. (1991), o principal elemento de coordenação do agribusiness é o tecnológico. Mesmo assim, numa visão que chamam de alternativa, são incorporados os atributos dos produtos como a qualidade, a nutrição, a segurança do alimento e os interesses por aspectos ambientais como elementos que também induzem uma maior coordenação. A atuação de empresas privadas, principalmente as de grande porte, por intermédio da produção de alimentos de alta qualidade e da sua atuação como fiscalizadora ao longo do sistema agroindustrial, justifica-se na medida em que ela tem a certeza de que seu produto chegará com a qualidade desejada ao consumidor, sem contaminações que prejudiquem a imagem de sua marca.

Mudanças no ambiente institucional North (1990, op. cit.), devido às exigências do consumidor ou à imposição de leis que obriguem um maior nível de segurança do alimento, 
acarretam uma mudança nas organizações, no sentido de minimizarem seus custos através de uma maior coordenação vertical.

Podem ocorrer problemas na identificação do responsável pela contaminação de determinado produto, numa das etapas do sistema, como o supermercado, por exemplo. Este pode alegar que o produto já saiu da indústria contaminado, e a indústria alegar que foi contaminado, durante o transporte, ou no armazenamento.

Numa tentativa de evitar esse problema, Hobbs e Kerr (1992, op cit.) mostram o significativo impacto do "British Food Safety Act 1990" na estrutura do agribusiness britânico. Através da "due diligence", qualquer comprador de produto ou de insumo alimentar tem que se certificar de que o vendedor está fornecendo qualidade e segurança. Apesar de aumentar significativamente o nível de food safety e de determinar precisamente quem é o responsável pela segurança do produto, argumenta-se que a lei pode significar um aumento nos custos de monitoramento para o sistema alimentar. Certamente, haverá a criação de formas alternativas de coordenação vertical que minimizem os custos decorrentes dessa regulamentação. Além disso, tal como a direção de agregação (para frente ou para trás), vai depender da forma como está estruturado o mercado e do tipo de contrato existente. A coordenação também avança através dos processos tecnológicos, como é o caso da técnica de "rastreabilidade", que permite identificar a origem e o percurso que um alimento realiza desde a sua origem.

A idéia da coordenação imposta pela exigência de qualidade não se deve limitar às fronteiras do país. Produtos que têm um sistema agroalimentar que termina ou começa em países diferentes também se submetem a essa tendência. A imposição de barreiras nãotarifárias dificulta, principalmente, as exportações de produtos para países desenvolvidos, com um mercado altamente exigente.

Em um país como o Brasil, que enfrenta graves dificuldades econômicas e onde a maioria da população possui baixa renda, não podendo, em muitos casos arcar com os custos de garantia da segurança do alimento e as adaptações dos sistemas alimentares nacionais às novas exigências tornam-se lentas e difíceis, prejudicando ainda mais a sua competitividade. 
A encefalopatia espongiforme bovina (BSE) ou "doença da vaca louca", que ocorre em bovinos alimentados através de ração, em sistema de confinamento, e que afeta tanto o cérebro do animal quanto o humano, é transmitido, ao homem, por meio da ingestão da carne bovina contaminada (ENRIQUEZ-CABOT e GOLDBERG, 1996). Sua ocorrência abre uma discussão sobre o papel do Estado em garantir a segurança do consumidor. Esse fato tem possibilitado a criação e participação de associações de consumidores e entidades de interesse no monitoramento e na pressão por regulamentações mais severas.

Empresas privadas, principalmente as de grande porte, têm atuado por intermédio da produção de alimentos de alta qualidade e da fiscalização, ao longo do sistema agroindustrial, para ter certeza de que seu produto chegará com a qualidade desejada ao consumidor, sem contaminações que prejudiquem a imagem de sua marca. 


\section{III - MECANISMOS FORMAIS E INFORMAIS}

Este capítulo faz uma revisão de literatura sobre os conceitos e justificativas para o uso dos mecanismos de regulação, principalmente no que tange à oferta de produtos de alta qualidade. O papel do estado, as falhas de mercado, a assimetria informacional, a racionalidade limitada, o direito de propriedade indefinido e a ótica da escolha pública foram abordados como elementos que justificam e caracterizam a necessidade de uso dos mecanismos formais. As estratégias privadas que sinalizam ao consumidor uma maior qualidade do produto e possibilitam uma maior índice de recompra como as marcas e os fatores que podem gerar a sua lealdade como a confiança e a imagem positiva sobre a empresa ou produto, a utilização de ferramentas de marketing como os selos de qualidade e a comunicação, foram abordados como mecanismos informais. No capítulo seguinte, é apresentado um modelo que pretende avaliar a relação de uso dos dois mecanismos e do atributo preço simultaneamente. Mesmo sendo abordados em separado na literatura, é razoável supor que ambos os mecanismos têm um efeito sinérgico na percepção do consumidor sobre a qualidade do produto.

\subsection{Mecanismo Formal}

Neste item, serão discutidos conceitos e trabalhos que exploram a função ou o papel do Estado no monitoramento e no cumprimento da lei. Segundo Cohen (op. cit., 1998), o poder de "fazer cumprir" do estado e o seu monitoramento são definidos da seguinte maneira: 
"monitorar e fazer cumprir incluem o monitoramento e a inspeção pelo fazer cumprir das autoridade bem como as sanções, ações corretivas e outros mecanismos designados para punir e/ou trazer a firma em conformidade com. Ela, também, inclui as ações não governamentais tais como litígios de cidadãos autorizados pelo governo e mecanismos informais com a pressão pública". Regular ${ }^{18}$ significa definir normas que visam a um melhor nível de segurança do alimento e monitorar ${ }^{19}$ significa o avaliar o cumprimento destas normas. Ambos são produtos ofertados e exigidos pelo mercado.

\subsubsection{Papel do Estado}

Existem quatro componentes principais da regulamentação que distinguem a utilidade pública dos outros setores da economia: (1) controle de entrada; (2) fixação de preços; (3) imposição de uma obrigação para servir todas aplicações sobre razoáveis condições, (4) prescrição da qualidade e condições do serviço (KAHN, 1998, p. 3).

Diversos autores justificam a necessidade da intervenção do Estado (MERCURO e MEDEMA, 1997; VISCUSI, 1985; BUZBY, 1998; e POSNER, 1998). Para avaliar a intervenção governamental, é preciso relacionar a necessidade e o tipo de demanda a um ou mais tipos de falhas de mercado que podem advir da competição imperfeita, bens públicos, externalidades, mercados incompletos e informação imperfeita. Identificar se há ou não uma falha de mercado é uma etapa essencial para identificar o escopo apropriado para a ação governamental (STIGLITZ, 2000, p. 249). É fato que a segurança do alimento, dependendo do seu caso, pode estar relacionada a uma ou mais dessas falhas de mercado.

Conhecer o papel do governo é imprescindível para se analisarem a viabilidade e as conseqüências da introdução de programas e leis que impliquem ganhos no nível de segurança. O papel do governo é necessário, devido à inexistência de uma operação perfeita de mercado, para a comercialização de produtos que envolvam risco. Assim, podem ocorrer divergências entre os níveis ótimos de satisfação privados e sociais, quanto à qualidade e à segurança do alimento, por exemplo. Nem sempre os níveis desejados ou aplicados pelas empresas correspondem ao demandado pela população.

\footnotetext{
${ }_{19}^{18}$ Relativo a regra. Que é ou que age conforme as regras, as normas, as leis, as praxes.

${ }^{19}$ Acompanhar e avaliar.
} 
Henson e Traill (1993) argumentam que, na prática, o funcionamento perfeito do mercado para produtos que envolvem risco não existe e que há uma divergência entre os níveis ótimos privados e sociais de segurança alimentar. As principais causas são: (1) percepção de risco do consumidor, que difere da dos especialistas; (2) imperfeições na oferta de informações sobre segurança do alimento; (3) falha do sistema de preços em refletir os custos e benefícios totais associados com as mudanças no nível de segurança do alimento e (4) inaceitável distribuição, dentro da sociedade, dos custos e benefícios associados a mudanças no nível de segurança do alimento.

Knutson (1993), em estudo realizado nos Estados Unidos, atenta para o fato de que as exigências do novo registro para produtos desse país, que têm como base a redução gradual nas aplicações de pesticidas, reduzem significativamente a produtividade de frutas e verduras. Portanto, na imposição de leis por parte do governo, devem ser analisados, com base em estudos, não só os níveis considerados ótimos de segurança, mas, também, a viabilidade econômica dessa exigência. Além desse problema, o risco associado precisa ser bem avaliado e ponderado, de acordo com o nível de segurança desejado.

Independente de leis ou de imposições quanto à questão da segurança dos produtos alimentares, a conscientização e a informação do consumidor, do governo e das empresas, quanto aos perigos da "insegurança alimentar", é, sem dúvida, imprescindível para a obtenção de produtos de qualidade, com um adequado nível de segurança.

Law (2001) argumenta que a intervenção governamental americana no setor de alimentos surgiu como resposta aos altos custos de transação decorrentes do aumento das necessidades de informações e que a regulamentação passou da esfera estadual para a federal devido, também, a incentivos advindos da diminuição de custos de transação pela substituição das várias regulamentações estaduais vigentes e pelo crescimento do comércio interestadual.

O autor também ressalta que a incerteza do consumidor cresceu, ao longo do tempo, devido à passagem da produção caseira de alimentos para a de mercado, pelo crescimento da troca impessoal e pelo desenvolvimento de novos produtos alimentares. A razão principal para a entrada do Estado no final do século XIX foi a questão relacionada às adulterações nos alimentos ocorridas neste período. No caso dos Estados Unidos, iniciou-se com a dificuldade de garantir a conformidade do produto e evitar adulterações. A adição de água 
em leite e de glucose em mel são alguns exemplos que incentivaram a inserção do Estado na regulamentação sobre alimentos.

Enfatizando o papel do Estado na geração de reputação (LAW, op. cit, p. 7), Law faz ressalvas com relação ao papel privado neste processo:

"É claro que a regulamentação governamental não é somente o único mecanismo disponível para induzir os produtores a prover informação confiável sobre a qualidade do produto aos consumidores, e, com isso, reduzir custos de transação. Existem muitas soluções privadas potenciais para o problema da assimetria informacional. As firmas podem oferecer garantias...".

O autor ressalta, também, o papel das auditorias e certificações (terceira parte) e do importante incentivo que as repetições de compra dos consumidores têm em relação à geração de qualidade pelas organizações. O aparecimento de firmas com várias unidades (multiunit), no início do século $X X$, decorre, também, da necessidade de algumas firmas gerarem reputação em relação à qualidade dos alimentos. Apesar disso, e sem muito aprofundamento, afirma que o governo deve ser mais eficiente na detecção e punição dos que não possuem qualidade. Talvez essa afirmação merecesse uma melhor discussão.

\subsubsection{Oferta de direito de propriedade pública}

Segundo Barzel (1997, p. 3), o direito de propriedade assume dois significados distintos na literatura econômica. Um desenvolvido por Alchian (1965 e 1987) que significa, essencialmente, a habilidade de desfrutar de uma propriedade. Outro se refere ao que o Estado cede para uma pessoa. O próprio autor define como:

"o direito de propriedade que um indivíduo possui sobre uma commodity ou ativo sendo a habilidade do indivíduo, em termos de expectativas, de consumir a mercadoria ou o serviço de um ativo diretamente ou consumi-lo indiretamente por meio de uma troca".

Já o direito legal é definido como "o que o governo delineia e faz cumprir como uma propriedade das pessoas" (BARZEL, op. cit, p. 90). Entendendo a segurança do alimento não somente como um atributo, mas como uma mercadoria que pode ser ofertada no mercado em determinado nível, o Estado pode garantir um nível mínimo desejado pela sociedade e, com isso, oferecer um nível adequado de bem estar. 
A determinação do direito de propriedade é questão fundamental para se determinar o papel do Estado. A indefinição do direito de propriedade, com relação à segurança sobre o consumo de um alimento, mostra a necessidade da atuação do Estado ${ }^{20}$ (DEMSETZ, 1967). A preocupação com a adequada e saudável alimentação da população é um componente essencial para as metas de saúde dos países para o futuro. Cada meta vai depender do estágio de desenvolvimento e do interesse de cada país em desenvolver programas que garantirão a segurança do alimento.

Segundo Stiglitz (2000, p. 128), um bem público tem um consumo não rival (non-rival consumption), ou seja, pode ser consumido simultaneamente por vários indivíduos da sociedade e não tem o poder de exclusão. Nesse caso, a segurança do alimento é um bem público e sujeito às imperfeições do mercado que ocorrem pelo pouco consumo (underconsumption) ou pelo pouco fornecimento (undersupply), (STIGLITZ, op. cit, p. 129). O autor também salienta o problema do "carona" (free rider), na medida em que existem alguns indivíduos que relutam em não contribuir voluntariamente para dar suporte ao bem público. Ao não pagar impostos e na ilegalidade, a empresa de alimentos não contribui para a manutenção dos órgãos reguladores e fiscalizadores, por exemplo. Assim como Krauss (2002), definimos produto de responsabilidade civil (product liability) os recursos legais, quando um alega defeito em um produto tangível que causa dano à propriedade ou injúria pessoal.

Dado que o nível de segurança pode ser exigido e oferecido em vários níveis, Figura 4., as "falhas de mercado" e os interesses nem sempre convergentes entre o bem público e o bem privado fazem com que ocorram divergências entre o desejado pelo setor privado e o desejado pelo setor público em termos do nível considerado adequado de qualidade e segurança. Isso permite brechas para ações "oportunísticas" por parte de organizações que possam utilizar ou restringir conhecimentos e informações sobre aspectos do produto.

\footnotetext{
${ }^{20}$ Definição de quem deve pagar a quem a utilização ou a garantia de determinado recurso ou serviço. No caso, quem deve garantir e arcar com os custos de um nível adequado de segurança do alimento? Para um aprofundamento do tema, leia Zylbersztajn (1995, cap. 2).
} 


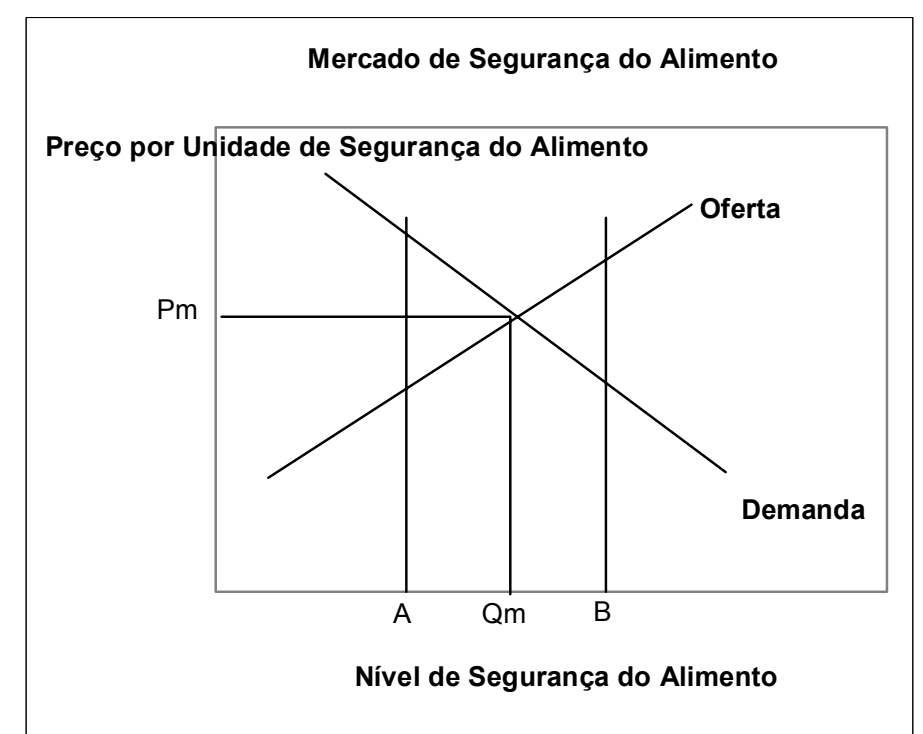

Figura 4. Oferta e demanda por níveis de segurança do alimento

Se entendermos que, em alguns casos, a segurança do alimento é definida como um serviço oferecido por uma empresa, pela sua variabilidade, a responsabilidade pela oferta de boa qualidade recai praticamente sobre a empresa e, não, sobre o órgão regulador. Os padrões de qualidade em serviços são muito difíceis de serem especificados por meio de regras e, quando o são, podem gerar controvérsias. Particularmente isso se agrava com a introdução de novos serviços, como é o caso das inovações constantes relacionados à produção e à conservação dos alimentos. No sistema onde a empresa realiza a gestão e o governo a supervisão, o papel do órgão regulador é o de definir o mínimo de padrão de qualidade e realizar periódicas inspeções (KAHN, 1998, op. cit. p. 22).

\subsubsection{Assimetria informacional e racionalidade limitada}

A falha de mercado advinda da informação assimétrica é evidenciada por vários autores (LAW, 2001; AKERLOF, 1970; KATZ, 1998 e STIGLER, 1961). A presença de contratos incompletos e de assimetria de informação permite ações "oportunísticas" por parte dos agentes. Sendo os agentes oportunistas e existindo, no mercado, a assimetria de informação, há necessidade de intervenção do governo no monitoramento pois, nem sempre, o nível ótimo privado coincide com o nível ótimo social. 
Fatores relacionados indiretamente com o produto, como as informações contidas na embalagem, também são considerados importantes pelos consumidores. O papel do governo também é importante, na medida em que se devem estabelecer legislações que aumentem as informações disponíveis sobre o produto, evitando assimetrias e ações oportunísticas.

O consumidor tende a simplificar as informações que recebe, ou seja, tende a gerar figuras simplistas do mundo real, de onde toma suas decisões. Segundo Miller (1956), a mente humana tem um limite de, no máximo, sete, mais ou menos duas variáveis ou atributos, que podem ser avaliados conjuntamente na escolha de um alimento. Isso faz com que ocorra um viés, por parte do consumidor, quanto à percepção de risco (dissonância cognitiva), tendendo ele a subestimar certas doenças causadas por alimentos, como o câncer e as de origem coronárias, e a superestimar outras, como é o caso do botulismo e das moléstias causadas por aditivos (FRAZÃO, op. cit.). A mídia, também, tem um papel importante, pois, em certos casos, faz com que haja uma subestima dos efeitos maléficos por meio da propaganda, que explora, apenas, os atributos benéficos. Portanto, somente numa situação onde a percepção do consumidor e a realidade são iguais (informação simétrica), é que se pode ter a maximização da satisfação.

Demandas por mais e melhores serviços, além da conscientização sobre a ecologia, a saúde física e o bem-estar, aumentam o interesse pelos atributos relacionados com a qualidade e a segurança dos alimentos. Novas demandas são ditadas pelos consumidores. Decisões de compra, que, antes, eram baseadas nos aspectos de variedade, conveniência, estabilidade de preço e valor, agora envolvem, também, a avaliação de características adicionais intrínsecas, como a qualidade dos produtos (quanto leite está presente em uma fatia de queijo, por exemplo), a nutrição (conteúdo de gorduras e colesterol), a segurança do alimento (aditivos presentes) e aspectos ambientais (relacionados à tecnologia de produção ambientalmente equilibrada), Streeter et al. (1991).

Alguns dos principais riscos e ameaças percebidos pelos consumidores, pesquisados por Tybor (1991), são: presença de resíduos, tais como pesticidas, inseticidas, herbicidas, antibióticos e hormônios em animais ou de aditivos como conservantes, nitratos e corantes (químicos em geral); utilização de processos como a irradiação de alimentos; utilização de sementes de alimentos geneticamente modificadas; deterioração causada por germes, fungos e bactérias; embalagem impróprias; fraude, como peso inferior ao especificado na 
embalagem; manuseio inadequado pelos empregados e ou compradores de supermercados e outros estabelecimentos de venda de alimentos; poluição ambiental causada pelas sobras, processos de produção ou embalagens dos alimentos; dúvidas quanto ao processamento e/ou preparo de alimentos; presença de insetos e ratos.

Akerlof (1970) descreve a existência de assimetria de informação, argumentando que o vendedor sabe muito mais a respeito da qualidade e da segurança do produto do que o comprador. O mesmo pode ser estendido para o caso da compra de um alimento. Substâncias que podem acarretar perigo para a saúde humana nem sempre podem ser visualizadas externamente em um alimento (atributos intrínsecos). A presença de doses altas de pesticidas e de aditivos, entre outros, só pode ser detectada em testes de laboratório.

A assimetria de informação permite a ocorrência de ação oportunística, por parte do mercado. Como exemplo, um agricultor ou uma indústria alimentar, na intenção de diferenciar seu produto, atingir novos nichos de mercado e aumentar o valor do seu produto, pode alegar que ele é isento de aditivos, pesticidas ou agrotóxicos. Por não ser visualizada externamente e, muitas vezes, por falta de metodologias apropriadas, de laboratórios especializados, ou devido ao elevado custo, a veracidade da informação não pode ser constatada.

Uma possibilidade de evitar ou atenuar a ocorrência desse tipo de ação oportunística está na criação de certificados que assegurem padrão de qualidade, juntamente com uma legislação mais rigorosa, que puna e controle esse tipo de atitude. O Estado pode fiscalizar, por intermédio de organizações independentes, os chamados certificadores e auditores de qualidade.

O Homem, certamente, difere dos animais em seu consumo, mesmo quando o produto atende a uma necessidade básica como a alimentação.

Em que e a partir de quando o homem se distingue do animal em sua alimentação? Pelo tipo de alimentos que consome ou por sua variedade? Pelo modo como os prepara antes de comê-lo? Pelo cerimonial que envolve seu consumo, a comensalidade e a função social que caracterizam as refeições? (FLANDRIN e MONTANARI, 1996, p. 26, tradução nossa)

A sua racionalidade permite que se façam escolhas antes da compra com base em vários fatores extrínsecos e intrínsecos a ele associados como o preço, especificações técnicas, 
motivações, expectativas, percepção de risco e, após o seu consumo, pelo preparo da refeição, experiência de qualidade e características sensoriais (GRUNERT, 2001). Outros fatores como conveniência, serviços e confiança também podem influenciar a decisão de consumo.

As decisões de consumo são tomadas por meio da avaliação de alternativas que têm, como base, um modelo de decisão e informação. Tudo se inicia com a percepção das necessidades e, posteriormente, busca de informações que permitam avaliar as alternativas que melhor o satisfaçam, maximizando, assim, a sua função utilidade. Essa afirmação é válida quando a racionalidade é ilimitada e quando não existe assimetria informacional.

Com relação à racionalidade limitada, aspectos de qualidade ligados a atributos intangíveis como é o caso de serviços (como serviços adicionais incorporados ao processo de produção relacionados ao aumento de qualidade em alimentos como a metodologia de APPCC, por exemplo), diferentemente dos produtos, são difíceis de serem caracterizados e avaliados. Com relação à assimetria informacional, pode haver a omissão de informações que seriam consideradas importantes pelo consumidor no seu processo de decisão de compra.

Por ser a segurança do consumidor um bem público, a estrutura do ambiente institucional poderia contribuir para reduções dos custos de transação e, conseqüentemente, uma melhor eficiência e eficácia no seu atendimento. A percepção com relação a aspectos de segurança em alimentos é amplamente abordada na literatura. A percepção do consumidor em relação aos alimentos geneticamente e não geneticamente modificados, por exemplo, é associada a este último, "a percepção de aspectos negativos como não salutar e incerto" (GRUNERT, 2000). Essa percepção nem sempre é associada a características racionais, mas, também, emocionais. No caso de energia renovável, Bang et. al. (2000), atestam que a preocupação com o meio ambiente e crenças sobre energia renovável é mais emocional do que baseada em fatos e colocam as implicações disso para as estratégias de marketing e educação do consumidor.

Do ponto de vista do consumidor, o aparato institucional não tem proporcionado o nível de segurança esperado. Ações dos segmentos de produção e industrialização de alimentos têm gerado crescentes e sucessivas crises de credibilidade, medo e insegurança, devido a acusações de contaminações e adulterações em seus produtos. Outros fatores que contribuem para essa desconfiança são a pouca compreensão dos crescentes 
aprimoramentos tecnológicos obtidos no processamento através da engenharia genética, da constante introdução de características intangíveis, que são pouco percebidas pelo consumidor, da introdução de novos ingredientes e substâncias, além das características funcionais. Embora traga benefícios tanto para o produtor quanto para o consumidor, alguns consumidores e organizações não governamentais (ONGs), acreditam que essas tecnologias possam ser muito perigosas se mais intensamente exploradas e sem o controle adequado por parte do estado.

Law (op. cit, p. 8, tradução nossa), afirma que o consumidor demanda mais informações e que eles:

\begin{abstract}
"obviamente ganham com uma regulação que force as firmas a prover informações confiáveis sobre a qualidade dos produtos que vendem, desde que estas informações permitam a eles realizar melhores escolhas relacionadas a mercadorias e serviços que eles compram".
\end{abstract}

Já Frewer, et. al. (2000, tradução nossa) argumentam que:

"a característica da fonte da informação influencia a escolha do consumidor em relação a alimentos geneticamente modificados. Em particular, os consumidores têm mais probabilidade de escolher os alimentos geneticamente modificados se a fonte que provê a informação é percebida como sendo honesta...".

Milne e Boza (1999) evidenciam, empiricamente, por meio de uma pesquisa nacional, que melhorar a confiança e diminuir a preocupação são conceitos distintos na gestão da informação ao consumidor. Melhorar a confiança mostrou-se mais eficiente do que esforçarse em reduzir a preocupação.

Os consumidores podem obter as informações sobre segurança de alimentos de diversas fontes. Buzby e Ready (1996), relatam uma pesquisa realizada nos EUA com, aproximadamente, mil consumidores. Com relação à fonte de informação de onde recebem informações sobre segurança de alimentos, $70,1 \%$ mencionaram jornais e $71,3 \%$, a televisão. Aproximadamente $50 \%$ recebem as informações em embalagens e somente $16,5 \%$ obtêm do Governo. Já com relação à confiança da informação, 52,3\% confiam completamente nas informações divulgadas pelo governo e 45,7\%, completamente, nas informações das embalagens ${ }^{21}$. Somente $8 \%$ confiam nas informações divulgadas pela televisão $(6,2 \%$ jornais, $5,2 \%$ revistas e $3 \%$ folhetos de lojas). Apenas uma minoria $(1,4 \%)$ 
confia completamente nas informações divulgadas em propagandas. Esses resultados mostram a eficiência das firmas em prover informações e do Estado em gerar confiança.

A teoria da psicologia cognitiva para a regulamentação de atividades que envolvam risco tem sido explorada por diversos autores, entre eles, Katz (1998 op. cit.), Sunstein (2000) e Choi e Jensen (1991).

\subsubsection{A ótica da escolha pública}

Embora não seja objeto central deste trabalho, entender a origem da regulação de alimentos é importante. A teoria da escolha pública (public choice) é a aplicação do método e do aparato analítico da economia moderna ao estudo do processo político (BUCHANAN, 2000, p. 153).

Nem sempre as leis podem ser formuladas de acordo com o desejo dos consumidores. Apesar disso:

"os interesses dos consumidores não são necessariamente equivalentes
aos de toda a comunidade. As agências reguladoras, as quais respondem,
exclusivamente, aos interesses dos grupos de consumidores, podem
produzir resultados que são, relativamente, mais eficientes que as agências
que respondem exclusivamente às demandas das firmas reguladas"
(BUCHANAN, op. cit. p. 331 , tradução nossa). O crescente poder de influência proporcionado pela mídia e pelas associações de defesa dos consumidores faz com que a maioria dos seus interesses sejam atendidos o que, em alguns casos, pode inviabilizar economicamente uma atividade. A crescente tendência de aumento no rigor na legislação européia quanto à produção e comercialização de alimentos é um exemplo.

Mercuro e Medema (1997, p. 96) evidenciam o problema da prática da política pela busca de renda econômica (rent seeking) que é usada para descrever o recurso gasto por um indivíduo em disponibilizar seu tempo para transferir valor sob a égide do Estado. A transferência de recursos do Estado para a iniciativa privada para investimentos em

\footnotetext{
${ }^{21}$ Existe uma possível correlação entre a confiança em relação às informações providas pelo Estado e as informações contidas na embalagem, já que esta ultima é regulamenta pelo próprio governo.
} 
programas de melhoria da segurança do alimento podem ser mal utilizados ou desviados para outras finalidades.

Segundo Mises (1949), apud Smith e White (1999, op cit., p. 195, tradução nossa):

"Dificilmente não há nenhuma intervenção governamental no processo de mercado que, olhado sob o ponto de vista das preocupações dos cidadãos, não terá que ser qualificada como um confisco ou como um presente... Não há tal coisa como o método justo e leal de exercer o tremendo poder que o intervencionismo põe nas mãos dos legisladores e executivos. Nós também vemos mesmo na prenuncia da renda econômica e da escolha pública quando ele resume sua discussão de corrupção como um inevitável efeito do intervencionismo. Então, a teoria da escolha é muito mais do que o lado econômico do empenho humano, ela é central sobre todas as ações humanas".

É, portanto, importante salientar que, mesmo em se formulando mecanismos formais de regulação, a existência de corrupção pode afetar o seu fazer cumprir e, conseqüentemente, a sua eficiência em gerar bem-estar. Uma organização pode ser detectada por um órgão fiscalizador, mas não ser punida devido à existência de corrupção.

Law (op. cit., p. 9), comenta que existem, por parte de determinadas organizações privadas, atitudes de "lobby" para a adoção de regulamentações padrões de qualidade superior pois possuem maior vantagem competitiva na produção destes produtos.

A escolha de normas não diretamente envolvidas com a regulação da qualidade e segurança do alimento também é relevante. Incentivos à não adoção de mecanismos formais como os relacionados a ganhos fiscais, por exemplo, incentiva a ilegalidade da organização sendo ela, portanto, não sujeita à autuação. Akerlof (1970, op. cit.) enfatiza, na introdução do seu trabalho, que "os negócios nos países em desenvolvimento são difíceis, em particular, a estrutura é dada pelo determinismo do custo econômico e desonestidade".

Outros órgãos vêm complementando o papel de fiscalização e, portanto, devem ser levados em consideração na escolha pública. O Instituto de Defesa do Consumidor (IDEC, 2002) e a Fundação Procon (PROCON, 2003) são exemplos nacionais de organizações que podem influenciar a reputação da empresa e a compra do consumidor. Essas associações ou organizações sem fins lucrativos (ONGs) de consumidores e de entidades de interesse exercem o monitoramento e a pressão por regulamentações mais severas. As empresas, por sua vez, para defender seus interesses, organizam-se por meio de associações como a Associação Brasileira das Indústrias de Alimentos (ABIA, 2002). 


\subsection{Mecanismo Informal}

As motivações consideradas internas à organização que levam uma empresa a adotar um mecanismo informal de controle da qualidade são de difícil mensuração e podem variar de empresa para empresa. A melhoria na sua eficiência produtiva, a melhor gerência dos controles de qualidade, as melhorias no serviço ao consumidor, a facilidade de introdução de novos agentes, a facilidade de solução de problemas, o possível aumento de marketshare e a manutenção de consumidores são alguns exemplos. Conforme discutido no capítulo um, essas motivações internas não são objeto deste estudo. O objetivo, aqui, é focar nas motivações consideradas externas como a demanda por mais qualidade pelo consumidor e mais rigor na fiscalização do governo.

O que se pretende é revisar as principais estratégias de posicionamento ${ }^{22}$ que as organizações privadas podem utilizar para sinalizar ao seu público alvo as características de qualidade do produto. Esses mecanismos informais são vistos, aqui, como ferramentas que têm como objetivo aumentar a confiança e o índice de recompra ou lealdade ao produto. Nesse sentido, são abordadas estratégias como o uso de marca, selos de qualidade e comunicação.

\subsubsection{Marca e reputação}

Algumas empresas privadas definem direitos de propriedade sobre bens regulamentados que identificam padrões de qualidade aceitos e percebidos pelo mercado como as marcas registradas (ELIAS, 2000).

O aumento da complexidade dos mercados e a intensificação da competição são fatores que, usualmente, figuram na lista de justificativas para o declínio dos consumidores leais. Clientes de certos segmentos, pouco fiéis às marcas, exigirão mais gastos das organizações em comunicação em busca de maximizar seu valor. No caso da carne, isso se torna mais complexo ainda pelo fato de ser considerada uma commodity e, sendo assim, os

\footnotetext{
${ }^{22}$ Segundo Ries e Trout (2000), posicionamento "começa em um produto. Uma peça de merchandising, um serviço, uma companhia, uma instituição, ou mesmo uma pessoa .... Mas posicionamento não é o que você realiza sobre um produto. Posicionamento é o que você realiza na mente do consumidor, ou seja, você posiciona o produto na mente do público alvo.
} 
consumidores encontram dificuldades cognitivas de percepção entre os diferentes níveis de atributos de qualidade. Assim, não haveria motivos para ser leal à determinada marca.

\begin{abstract}
"As marcas são ferramentas para se conquistar a confiança dos consumidores de carne. Algo como tranqüilizar o consumidor de que pode apreciar o alimento, certo de que todos os problemas foram resolvidos pelos responsáveis pela marca" (Gwin Howells, Diretor Geral do Meat Livestock Commission - MLC (FOz, 2001, p. 24).
\end{abstract}

Entre as motivações que os agentes privados possuem para criação de uma marca, é a de gerar, nos consumidores, confiança o suficiente para que sejam leais ao seu produto aumentando a expectativa de ganhos futuros. O objetivo é se destacar em mercados altamente competitivos, onde existem consumidores que valorizam atributos de qualidade.

Um dos papéis do mecanismo informal da marca é gerar a recompra. Segundo Arnold (1992, p. 7, tradução nossa):

"o objetivo das organizações é o de criar valor na mente dos consumidores, um ponto comum entre o consumidor e o produto ou serviço. Isso significa ter produtos e mensagens renovadas na mente dos clientes e induzir a recompra".

"Marca é um nome, termo, sinal, símbolo ou combinação dos mesmos, que tem o propósito de identificar bens ou serviços de um vendedor ou grupo de vendedores e diferenciá-los dos concorrentes" (ARNOLD, op. cit, p. 2). Toda marca estrutura-se em torno de dois fatores básicos: os atributos associativos, associação feita pelo consumidor em relação a determinada marca ou produto, e os valores agregados, imagem, personalidade e representações visuais do produto. Os atributos associativos, por sua vez, são compostos por variáveis funcionais que operam no plano racional, como o desempenho e a performance do produto ou por variáveis emocionais que operam no plano subjetivo, como relações de prestigio, poder, status, entre outros. Já os valores agregados necessitam de um longo e delicado processo resultante, geralmente, de um longo intervalo de tempo para criar, manter e desenvolver a imagem, personalidade e representação visual na mente do consumidor (KOTLER, 2003, p. 418.

As marcas, quando bem construídas, têm a capacidade de criar, estabelecer e manter relacionamentos de grau afetivo entre o consumidor ${ }^{23}$ e o produto (ARNOLD, op. cit. p. 12). Traduzem-se forma marcante e decisiva, o valor do uso de determinado produto. São a

\footnotetext{
23 "estar na mente dos consumidores" é um dos elementos mais críticos para a formação de valor da marca.
} 
forma de identificação dos produtos comprados e proteção do consumidor quanto à sua origem e qualidade. É um mecanismo utilizado para criar, manter e enriquecer os apelos que estabeleçam a melhor relação possível entre o consumidor e o produto. Diferentemente de atributos que possuem datas de vencimento, a marca, quando registrada, é protegida por lei ou mecanismo formal e garante à organização o direito exclusivo de propriedade e uso.

Por estar representada por um nome, uma designação, muitas vezes um sinal, um símbolo para identificar bens ou serviços de um vendedor e diferenciá-los dos concorrentes, a marca acaba passando informações, atributos, imagem, benefícios e, principalmente, valores e reputação. É por esse valor que a marca possui que pode ser medida a sua aceitação, consciência e lealdade das pessoas com relação a ela (BATRA E OLLI, 1991).

A seguir, serão discutidos conceitos importantes relacionados à marca que são: valor, confiança e lealdade. $\mathrm{O}$ conceito de valor entregue ao consumidor é a diferença entre o valor total e o custo total. Valor total para o consumidor é o conjunto de benefícios esperados de determinado produto ou serviço. O custo total para o consumidor é o conjunto de custos esperados na avaliação e uso do produto ou serviço. Os consumidores são maximizadores de valor limitados por seus custos, conhecimentos, mobilidade e renda. Formam expectativa de valor e agem sobre ela, sendo sua satisfação e probabilidade de recompra dependente dessa expectativa de valor ser ou não superada. A mensuração do valor de uma marca está relacionada ao que os consumidores estimam para tomar suas decisões com base na oferta que agrega maior valor a eles. O uso da marca pode diminuir o custo da decisão de compra.

O conceito de confiança (ROTTER'S, 1967, p.651) está relacionado a como a expectativa de determinado indivíduo pode ser respondida por outro indivíduo com a máxima certeza e, acrescenta que, entre ambas as partes, deve existir, ainda, a certeza de que são capazes de executar suas tarefas de acordo com o estipulado. A confiança na marca (brand trust) segundo Morgan and Hunt (1994 p. 23) é a disposição do consumidor em responder à habilidade da marca em sua função especifica. Segundo Morgan (op. cit), a noção de confiança é apenas relevante em situações de incerteza. Especificamente, confiança reduz a incerteza no meio, na qual consumidores se sentem vulneráveis a certas variáveis como qualidade, procedência do produto ou serviço. Sendo assim, percepções de dignidade, segurança e honestidade são variáveis importantes de confiança que pessoas levam em consideração na hora de tomarem suas decisões. 
Segundo Creed e Miles (1999, p. 19) a confiança pode ser resumida em uma simples função: confiança $=\mathrm{f}$ (predisposição a confiar embutida, características de similaridade ${ }^{24}$, experiência de reciprocidade). Portanto, a confiança pode ser percebida pelo incremento das similaridades e do número de trocas positivas.

A confiança pode ser a base para a lealdade. Variáveis como integridade, consistência, competência, honestidade, justiça, responsabilidade e benevolência são essenciais para gerar confiança. O aumento de confiança proporciona melhor comunicação entre parceiros (e, no caso inverso, "desconfiança gera desconfiança"). Pode-se, ainda, dizer que muitos serviços ou produtos dependem do gerenciamento de confiança eficaz, na medida em que muitos dos consumidores precisam comprar o serviço ou a idéia antes de experimentar o produto ou serviço. Se não há confiança na marca por parte do consumidor, ele pode se recusar a experimentar determinado produto por receio de má qualidade, serviço, atendimento, entre outros.

A lealdade é a expectativa ou nível de intensidade da busca do prazer, do bem-estar ou da felicidade que o consumidor desenvolve com relação ao consumo de um produto. Coloca-se a expectativa em evidência, em vez da necessidade, pelo fato de a primeira envolver os aspectos sentimentais, criando laços muito mais fortes entre o consumidor e a marca, ao passo que a segunda pode estar no plano mais racional, em que o envolvimento tende a ser menor.

Um dos fatores determinantes da lealdade é a percepção do risco. Quanto maior for o risco envolvido no processo de compra, qualidade e performance do produto, tanto maior será a busca de garantias por parte do consumidor, sendo a marca um importante mecanismo reforçador positivo nesta escolha.

O nível de intensidade da lealdade deriva diretamente de dois fatores: atratividade e intervalo de compras, em que a atratividade vai determinar o quão envolvida a pessoa está no processo de compra (quanto maior o envolvimento mais leal será a pessoa) e o intervalo de compras, em que, à medida em que compro com mais freqüência, tendo a ser mais leal ou desenvolver confiança maior.

\footnotetext{
${ }^{24}$ Expectativas baseadas no conhecimento das atitudes do indivíduo, empresa ou instituição.
} 
Segundo Wansink e Ray (p. 34, 1996), lealdade à marca (brand loyalty) é um alto compromisso de recompra do produto ou serviço no futuro, de forma consistente, causando, assim, repetidas compras da mesma marca. Dentro desta definição, podemos considerar dois diferentes aspectos: o comportamental (behavioral) ou o de compra leal (purchase) que enfatiza que a lealdade consiste em compras repetitivas da mesma marca, ao passo que o aspecto atitudinal inclui o grau de compromisso em termos do valor único associado à marca.

A lealdade à marca é a tentativa do consumidor de garantir a manutenção do bem estar conquistado com o consumo do produto, buscando continuar experimentando essa sensação com a marca preferida. Portanto a lealdade estabelece uma relação de continuidade entre consumidor e marca, na busca de recompensas e satisfação pessoal. (WANSINK e RAY, op. cit, tradução nossa).

"Quando um cliente é leal, ele apresenta um comportamento de compra
definido como não aleatório expresso ao longo do tempo por alguma
unidade de tomada de decisões. O termo aleatório é fundamental. O cliente
leal tem uma tendência específica em relação àquilo que compra. Suas
compras não ocorrem aleatoriamente. Além disso, o termo lealdade denota
uma condição relativamente duradoura e exige que a ação de comprar
ocorra no mínimo duas vezes".

A lealdade, portanto, ampara-se nos fatores reforçadores das expectativas do consumo ou nos sentimentos de segurança, confiança e tradicionalidade. $O$ afeto à marca (brand affect) é definido como o potencial da marca para gerar uma resposta emocional positiva no consumidor, resultando em identificação e comprometimento.

Existem níveis de atitude do consumidor em relação à escolha de uma marca. Por exemplo, (1) não há lealdade à marca, portanto ele trocará de marca, por diversas razões (preço, por exemplo); (2) o consumidor satisfeito não tem motivos para mudança de marca; (3) o consumidor está satisfeito e tem algum custo para mudar de marca; (4) o consumidor valoriza a marca e (5) é leal à marca (KOTLER, op. cit).

Entre as vantagens que uma lealdade à marca pode trazer para a empresa estão: desfrutar de custos de comunicação menores, cobrar um preço maior do que seus concorrentes, lançar extensões da marca com maior facilidade em função da alta qualidade que ela representa e, por fim, defender-se contra a concorrência de preço agressiva. 


\subsubsection{Selos e certificados de qualidade}

Dentre os benefícios da utilização dos selos de qualidade, estão a diferenciação do produto, a maior confiança do consumidor e a conformidade com os órgãos (ISO, 2002) padrões internacionais exigidos de qualidade (OYARZÚN, 2001). Embora esteja sendo discutida como um mecanismo informal, pois está relacionado intimamente com a geração de reputação, o selo pode ser utilizado como mecanismo formal, à medida que pode ser utilizado como comprovação da inspeção do órgão regulador como é o caso do SIF.

Devido à presença de características de qualidade em um alimento não serem de fácil observação, como a ausência de resíduos ou aditivos, ou a garantia de um processo higiênico de produção, outro fato que vem marcando o desenvolvimento da qualidade no setor de alimentos na Europa, são os certificados que garantem atributos qualidade (OYARZÚN, 2001).

O intuito deste item é descrever a importância das estratégias de adoção dos selos de qualidade em alimentos. Dado o avanço em termos de tempo e de abrangência em sua utilização, o caso da União Européia (UE, 2002a e 2002b) e, em especial, da França (FRANÇA, 2003) serão evidenciados. Conhecer a situação dos selos de qualidade em alimentos é válido no sentido de avaliar possibilidade de introduzir estas estratégias no mercado local nacional.

A utilização do padrão, do selo ou da marca como ferramenta promocional pode variar em relação ao tamanho da firma e dos incentivos externos como o poder de mercado de fornecedores e consumidores, do ambiente legal e do grau de envolvimento no mercado internacional. Questões técnicas relacionadas à prática de padrões nos negócios também pode incentivar o seu uso.

Ações coletivas também são importantes para aumentar a credibilidade do consumidor e impor o papel de exclusão, separando produtos ou processos que geram alta dos que geram baixa qualidade. Exemplos são o selo de pureza e a certificação de origem utilizados no café pela Associação Brasileira das Indústrias de Café (ABIC).

Os certificados de qualidade atestam diferentes características do produto e ajudam o consumidor a entender essas características ou atributos particulares presentes. São 
adotados voluntariamente ou compulsoriamente, funcionando, também como um mecanismo formal.

Eles são fornecidos por um organismo certificador, que verifica e controla o produto, atesta os seus atributos de valor e os deixa visíveis para o consumidor pela presença de um logotipo ou símbolo, divulgando suas diferenças em relação a outros. Cada certificado ou rótulo de qualidade possui sua especificidade e transmite uma mensagem ao consumidor. Eles estão regulados oficialmente com a participação de entidades tanto privadas como públicas na execução do sistema e no seu controle.

Os selos podem ser uma ferramenta efetiva de comercialização para promover produtos alimentícios em mercados de consumidores informados e conscientes que, valorizam e estão dispostos a pagar mais pelos seus atributos. O consumidor consciente é seletivo e toma suas decisões baseadas nas informações sobre a natureza, produção e características específicas do produto. (CANTARELLI, 2000).

Os selos da União Européia classificam-se em: Denominação de Origem e Indicação Geográfica Protegida, Especialidade Tradicional Garantida e a Produção Orgânica. A França possui, também, o selo de qualidade superior (label rouge) e o de conformidade (MULDER, 1998; COMISIÓN EUROPEA, 2001).

A qualidade do alimento resulta de um processo que ocorre ao longo de toda a cadeia, da produção à mesa (ABLAN, 2000). Existem as categorias de qualidade de inocuidade, qualidade nutricional e atributos de valor:

Para garantir os atributos de valor é necessário criar estruturas de governança. Existem sistemas voluntários de controle que consistem em estabelecer uma entidade independente da empresa denominado "certificador" (SPERS e ZYLBERSZTAJN, op. cit. 1999). Esses organismos podem ser públicos ou privados. Quando o selo tem o seu logotipo como a sua marca registrada denominamos de "marca de qualidade".

Para que uma estratégia de adoção de um selo de qualidade seja factível, é preciso que o selo seja reconhecido pelo mercado, garanta que o organismo independente seja uma autoridade reconhecida, controlando e verificando as características de qualidade, e que o consumidor seja educado, diferencie e tenha condições de arcar com o valor adicionado. 
A Institut de Apelation Francais IAF reúne organismos de acreditação em nível internacional. No caso da França, o organismo reconhecido pelo IAF é o Comité Francés de Acreditación (COFRAC), na Argentina, é o Organismo Argentino de Acreditación (OAA), no Brasil, é o Instituto Nacional de Metrología - INMETRO (BRASIL, 2002e) e, no México, é a Entidad Mexicana de Acreditación (EMA).

\subsubsection{Informação e estratégias de comunicação}

Uma dos mecanismos informais que podem ser utilizados pelas organizações é a comunicação. A empresa pode utilizar-se das mídias disponíveis para promover a qualidade do produto e, com isso, aumentar a percepção de valor pelo consumidor. Klein e Leffer (op. cit, p. 632) argumentam que "uma análise da propaganda implica que os consumidores, necessariamente, recebem algo quando pagam um preço maior por uma propaganda da marca" e ainda que "a propaganda da marca do produto indica a presença de um preço prêmio atual e futuro" Evidências sobre a eficiência da propaganda na sinalização da maior qualidade do produto têm sido realizados (HORSTMANN e MACDONALD, 2003).

Embora algumas das estratégias de comunicação também possam estar relacionadas aos mecanismos formais, como, por exemplo, a definição de normas que estabeleçam níveis adequados de informação nutricional nos rótulos dos alimentos (MOJDUSZKA e CASWELL, 2000), está-se considerando, neste estudo, que a grande maioria das ações de comunicação são mecanismos formais do tipo propaganda, que visam melhorar a sinalização da qualidade percebida.

A comunicação entre o sistema produtor e o distribuidor para com o consumidor final tornase mais dinâmica e complexa. No caso de alimentos, a demanda de informações por parte do consumidor é alta, já que se trata de produto consumido diariamente e sujeito a constantes mudanças, tanto no seu processo de produção quanto no de conservação. A utilização de técnicas de bioengenharia genética para a produção de organismos geneticamente modificados, por exemplo, pode causar ruídos na comunicação entre empresa e consumidor e, como conseqüência, a incompreensão e desconfiança por parte dos consumidores, os quais, em muitos casos, superestimam seus efeitos. 
Soma-se a este fato a desconfiança em relação ao papel do Estado na garantia do direito à saúde e ao consumo de alimentos saudáveis, que foi agravada na Europa pela crise da "vaca louca". Algumas indústrias e distribuidores de alimentos tentam elevar a confiança do consumidor por meio da não produção ou não comercialização de produtos geneticamente modificados, por exemplo. Algumas empresas são acusadas de não informar adequadamente o consumidor sobre seus avanços científicos e respectivos riscos, criando uma percepção negativa e uma antipatia em relação aos seus produtos.

Empresas que têm sua estratégia baseada na diferenciação, com o oferecimento de produtos de qualidade, têm prejuízos com as imperfeições informacionais do mercado devido à dificuldade de discernimento do consumidor. Essas imperfeições, que nascem da falta de confiança, trazem sérias conseqüências como a desvantagem competitiva. Para as organizações privadas, a segurança do alimento precisa ser refletida no preço, para que as companhias que investem em qualidade persistam no mercado, embora em um ambiente onde todos sejam responsáveis não exista a vantagem competitiva e as variáveis de diferenciação sejam mais difíceis de ser implantadas.

Um das conclusões do trabalho de Frewer (op. cit.) é a de que a confiança nas fontes privadas de informação pode variar de país para país ou de ambiente institucional para ambiente institucional: "a indústria é percebida como sendo mais desonesta em prover informação sobre alimentos geneticamente modificados, na Dinamarca, Itália e Reino Unido, mas não na Alemanha, onde a indústria foi a mais confiável em relação às demais fontes".

Apesar do sensível crescimento dos aspectos de saúde na decisão de compra, existem poucos modelos que explicam o comportamento do consumidor. Os pesquisadores, comumente, focam em variáveis dependentes únicas como processamento de informações nutricionais ou variáveis independentes únicas como idade, classe social ou crença na saúde. Outra explicação é o caráter complexo e interdisciplinar desta preocupação (MOORMAN e MATULICH, 1993).

Segundo Lurie (1999, p. 11), os psicólogos têm estudado de que modo a quantidade de informação afeta o processo psicológico, tal como o reconhecimento do objeto e memória, enquanto as pesquisas de marketing explicam o processo de decisão (Tabela 2). Dada a crescente complexidade das informações sobre os atributos de qualidade e segurança do alimento, tanto o número de atributos quanto a estrutura dessas informações e a maneira 
como são transmitidas afetam o consumidor. Neste caso, tanto o mecanismo formal como o informal podem ajudar a diminuir essa complexidade, transmitindo, eficientemente, informações que auxiliem a compreensão do consumidor.

Tabela 2. O papel da informação nas áreas de psicologia e marketing

\begin{tabular}{|c|c|c|}
\hline & $\begin{array}{c}\text { Psicologia: Reconhecimento e } \\
\text { Memória }\end{array}$ & Marketing: Tomada de Decisão \\
\hline $\begin{array}{r}\text { Número de } \\
\text { alternativas de } \\
\text { atributos }\end{array}$ & Merkel & $\begin{array}{l}\text { Jacoby } \\
\text { Malhotra }\end{array}$ \\
\hline $\begin{array}{r}\text { Estrutura da } \\
\text { Informação }\end{array}$ & $\begin{array}{l}\text { Hyman } \\
\text { Garner } \\
\text { Miller }\end{array}$ & Lurie \\
\hline
\end{tabular}

Fonte: Adaptado de Lurie (1999, p. 11).

O comportamento da aquisição de informação em relação à saúde refere-se ao grau de informações que o consumidor recebe de várias fontes, incluindo a mídia, rótulos, amigos, familiares e profissionais de saúde. Segundo Moorman e Matulich (1993), são diversos os modelos utilizados para se verificar a aquisição da informação pelo consumidor descritos na literatura, agrupados em: comunicação, social, cognitiva, comportamental, marketing e combinado (Anexo C).

Smink e Hamstra's (1995) propõem um modelo de comunicação em que os principais e relevantes atores - governo, pesquisadores, produtores rurais, indústria de alimentos, distribuição, consumidores, associações de consumidores, associações de proteção ambiental - transferem a informação bruta em uma série de mensagens, sujeitando-as a vários graus de correção, completude, compreensão e credibilidade. Nele, a interação entre os mecanismos formais e informais pode ocorrer.

Alba e Hutchinson (2000), examinam o que os consumidores conhecem e o que eles pensam que conhecem. Em geral, os consumidores pensam que conhecem mais do que realmente conhecem e o que e como decidem varia em função deste conhecimento. Para isto, utilizam da metodologia de pesquisa de calibração (calibration research). Neste caso, é evidenciada a racionalidade limitada do consumidor quanto aos conhecimentos sobre algo complexo e que envolve aspectos emocionais como o entendimento sobre os impactos dos atributos relacionados à segurança do alimento.

Frewer et. al. (2000) investigaram o impacto de diferentes estratégias de informação sobre dois produtos alimentares em quatro países europeus. Entre as conclusões, está a de que, 
dependendo da honestidade da fonte de informação, o consumidor está mais ou menos disposto a consumir um produto geneticamente modificado. Essa atitude só é válida nas culturas em que a informação sobre alimentos geneticamente modificados está bem consolidada. Outra conclusão é a de que a geração de informação não resulta na maior aceitação de alimentos geneticamente embora o inverso seja verdadeiro. A transparência mostrou-se como um importante atributo para melhorar a confiança (trust) da organização perante o consumidor.

A confiança na ciência, no sistema regulatório e nos fornecedores da informação, pode ser tão importante quanto a geração da informação no sentido de influenciar as respostas do público com relação aos alimentos geneticamente modificados (FREWER, 1998).

Ariely (2000) testa um modelo geral para entender as vantagens e desvantagens do controle da informação sobre a qualidade da decisão, memória, conhecimento e confidência do consumidor. Seus resultados demonstram que o controle do fluxo de informação faz com que o consumidor atinja melhor sua preferência, tenha uma melhor memória e conhecimento sobre o domínio que está examinando e se torne mais confidente em seus julgamentos.

A comunicação é vista, no modelo proposto no capítulo seguinte, como um mecanismo utilizado pela empresa para aumentar o conhecimento sobre a marca (variável utilizada para mensurar o nível de presença do mecanismo informa) e com isso sinalizar a qualidade do seu produto. 


\section{IV - O MODELO TEÓRICO}

A proposta está baseada no modelo hedônico para mensurar a preferência dos consumidores por diferentes atributos relacionados aos mecanismos formais e informais. Elementos da teoria dos jogos são utilizados para avaliar as decisões públicas e privadas que permitam alcançar uma situação desejada de Pareto superior entre o consumidor e a empresa.

\subsection{O modelo hedônico e a percepção de valor}

No modelo desenvolvido por Lancaster ${ }^{25}$ (1971), os bens não são objetos imediatos de sua preferência ou utilidade, mas têm associados a eles um conjunto de atributos diretamente relevantes para o consumidor. Nessa formulação, a função utilidade é função do conjunto de atributos $\left(A_{j}=\Sigma a_{i}\right)$ ou características, obtidas através de uma série de produtos.

No modelo hedônico o produto i é definido como uma combinação de atributos $A_{j}=\left(a_{i}+a_{i+1}\right.$ $\left.+\ldots+a_{i+n}\right)$, que ele possui dada uma estrutura tecnológica de produção T. Quando os atributos de qualidade não são observados de forma perfeita pelo consumidor, no ato da compra, como é o caso da maioria dos atributos relacionados à segurança dos alimentos, uma empresa E, em determinado mercado j, pode oferecer o mesmo produto i com uma combinação diferente de atributos que varia de $A_{j}$ atributos com baixa qualidade a $A_{j}$ 
atributos de alta qualidade. À medida que segue ao longo da cadeia de valor ${ }^{26}$, o produto $\mathrm{i}$ sofre transformações a um custo $Z_{i}$ até ser oferecido ao consumidor final, que percebe um determinado benefício ou valor ${ }^{27} V_{i}$ no produto i (BESANKO, et al, 2000, p. 395).

Portanto, a existência de um produto i será função de $V_{i}$, que é o valor ou benefício médio percebido pelo consumidor em relação ao produto $\mathrm{i} ; \mathrm{p}_{\mathrm{i}}$, que é o preço de mercado pago e recebido pelo produto i e $Z_{i}$, que é o custo médio de produção do produto i. Na transação entre um consumidor $\mathbf{C}$ e uma empresa $\mathbf{E}$ que realiza a oferta do produto $\mathrm{i}$, o valor total gerado é dividido entre o consumidor e a empresa. Neste caso, $\left(V_{i}-p_{i}\right)$ é o excedente médio recebido pelo consumidor $\mathbf{C}$ e $\left(\mathrm{p}_{\mathrm{i}}-\mathrm{Z}_{\mathrm{i}}\right)$ é o lucro médio recebido pela empresa $\mathbf{E}$.

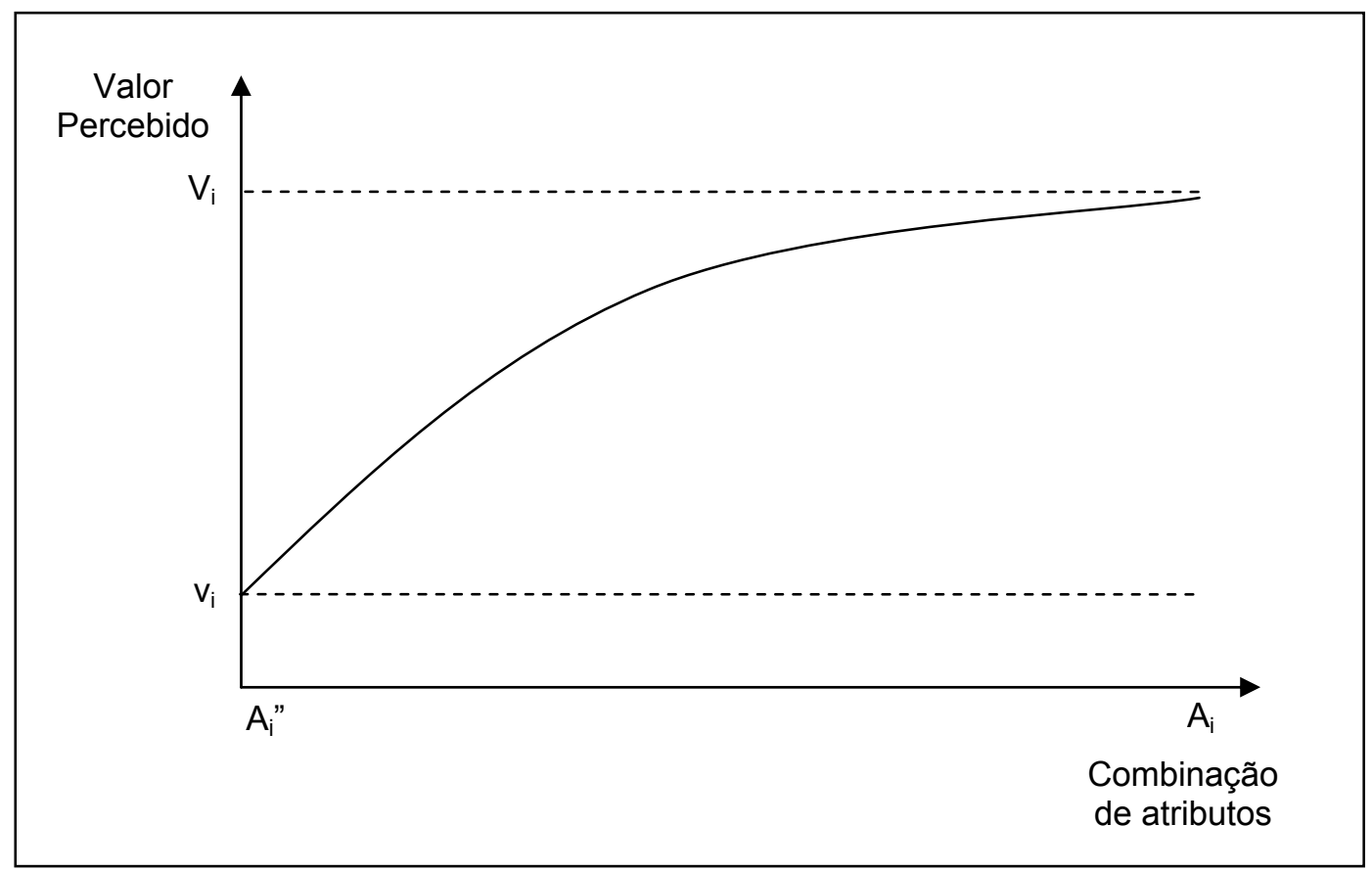

Figura 5. Percepção de valor do produto i em função da combinação de atributos

Existindo a possibilidade tecnológica de combinações distintas de produção $\mathbf{T}$, que são as combinações distintas dos atributos $A_{j}$, o produto i proporcionará benefícios distintos ao consumidor $\mathbf{C}$, que podem variar de um valor $\mathrm{V}_{\mathrm{i}}$, considerado maior, a um valor $\mathrm{v}_{\mathrm{i}}$ considerado menor $\left(V_{i}>V_{i}\right)$. Por exemplo, o consumidor percebe, na aquisição de uma

\footnotetext{
${ }^{25}$ Para um melhor detalhamento do modelo vide o Apêndice A.

${ }^{26}$ Segundo Porter (1989, p. 34) a cadeia de valor exibe o valor total das atvidades física e tecnologicamente distintas através das quais uma empresa cria um produto valioso para seus compradores e sua margem. ${ }^{27}$ Segundo Porter (1980, p. 125), "o aumento do valor adicionado amplia os atributos nos quais a escolha potencialmente se baseia". Esse valor pode ser mensurado em termos monetários pelo desejo de pagar (willingness-to-pay) do consumidor.
} 
determinada carne, que contém atributos que garantem um nível maior de segurança e qualidade, um valor maior do que outra carne que não possua os atributos ou que tenha um nível menor dos mesmos atributos (Figura 5).

Para a empresa $\mathbf{E}$ oferecer uma mercadoria de valor $V_{i}$ é sensato supor que a sua estrutura tecnológica de produção $\mathbf{T}$ possua custos maiores do que os de empresa que ofereça um valor $v_{i}$, pois incorpora procedimentos adicionais ${ }^{28}$ (Figura 6). Portanto, existindo a oferta de mercadorias com diferentes padrões de qualidade, a estrutura de custos do produto i pode variar de um valor de custo considerado maior $Z_{i}$ a $u m$ valor de custo $z_{i}$ considerado menor $\left(Z_{i}>z_{i}\right)$.

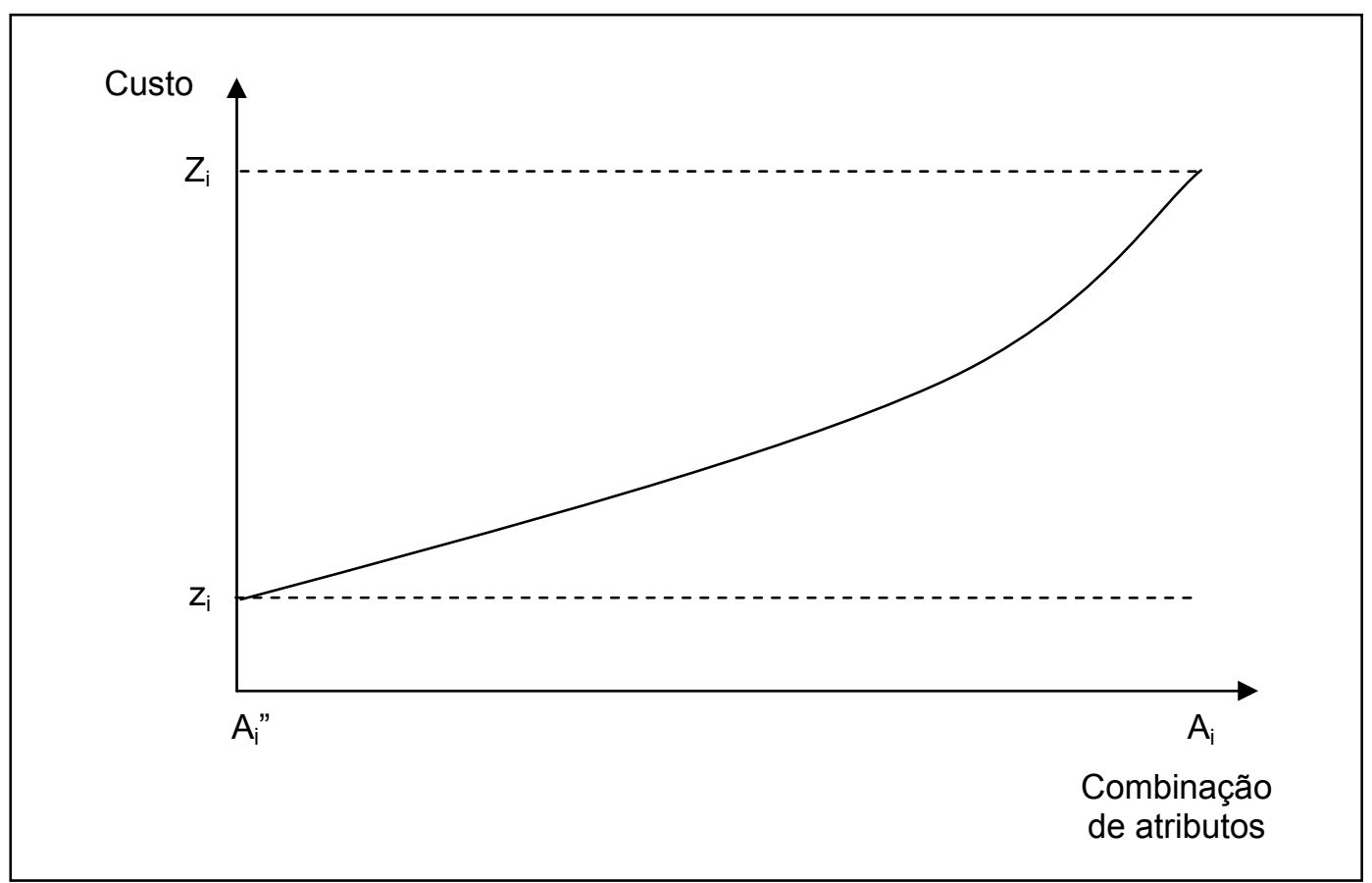

Figura 6. Custos do produto i em função da combinação de atributos

Mesmo que haja variações na percepção do benéfico dos atributos entre diferentes segmentos de consumidores, estamos supondo que exista uma parcela da população que os percebe e está disposta a pagar ${ }^{29}$ por um melhor padrão de qualidade. Supomos, ainda, que o consumidor $\mathbf{C}$ não compra o produto caso perceba uma baixa qualidade pois estaria pagando um valor $p_{i}$ maior do que o benefíco percebido $v_{i}$, ou seja, $\left(v_{i}-p_{i}\right)<0$.

\footnotetext{
${ }^{28}$ Como a Análise de Perigos e Pontos Críticos de Controle (APPCC) e as Boas Práticas de Fabricação (BPF), por exemplo.

${ }_{29}$ Assumimos que o efeito da reputação só existe em condições de quase-renda do consumidor.
} 


\subsection{O jogo}

Segundo Baird et al. (2000, p.6), "um problema estratégico se inicia quando duas pessoas interagem tendo que decidir o que fazer sem conhecer o que a outra está realizando." Por parte do produtor, a adoção ou o cumprimento de uma norma relacionada à segurança do alimento pode ser determinada por quão rigoroso é o Estado no monitoramento e na punição da empresa e no quanto de rigor esta empresa adota no cumprimento dessa norma. Ambos têm que decidir quanto rigor exercerão sem conhecer o rigor do outro. Esse comportamento também dependerá do regime legal. Podemos supor que a empresa adotará mais rigor na adoção da norma caso a punição imposta pelo ambiente legal seja maior.

Do lado do consumidor, a sua escolha também é afetada. Segundo Laffont e Tirole (1993, p. 211, tradução nossa):

"um monopolista que não sofre nenhum tipo de regulação terá dois
incentivos à adoção de padrões altos de qualidade e segurança. Quando a
qualidade for observável pelos consumidores antes do consumo
(denominado de bens de procura ou search good), a redução da qualidade
reduz as vendas e, portanto, a receita, quando o preço do monopolista
excede o custo marginal. De outra forma, quando a qualidade é observável
pelos consumidores somente após o seu consumo (denominados de bens
de experiência ou experience good), o monopolista não tem o incentivo para
prover um alto padrão de qualidade, a não ser que o consumidor repita sua
compra no futuro". Nesse sentido, surge o papel do mecanismo informal como a reputação e da marca e do mecanismo informal, como as normas, para que um alto padrão de qualidade e segurança dos produtos seja ofertado. Os mecanismos formal e informal são alternativos e podem interagir em termos da sua complementaridade ou substituição.

Assim como todos os modelos econômicos, a teoria dos jogos simplifica uma determinada situação social e tem sido utilizada no campo das organizações, do direito (KATZ, 1990) e do consumidor (GUNNTHORDSDOTTIR, 2002). Neste estudo, a aplicação desta teoria se dará no sentido de entender como os agentes econômicos se comportam diante de uma combinação variada de mecanismos formais e informais ${ }^{30}$.

\footnotetext{
${ }^{30}$ Para um maior aprofundamento na teoria dos jogos vide: KUHN (1997); OSBORNE, (1994); KREPS (2001); GIBBONS (1992). E para uma descrição prática e geral: DIXIT e NALEBUFF (1991).
} 
Para que um jogo ocorra, são necessários três elementos: (1) a existência dos jogadores, no caso a empresa privada e o consumidor ${ }^{31}$; (2) a estratégia disponível para os jogadores, no caso, comprar ou não por parte do consumidor e oferecer alta ou baixa qualidade e segurança por parte da empresa, cumprindo ou não o mecanismo formal ou adotando ou não o mecanismo informal; e (3) a compensação que cada jogador ${ }^{32}$ (FUDENBERG e TIROLE, 2002) recebe pela possível estratégia representada pelas diferenças entre valor e preço para o consumidor e entre preço e custo para a empresa. As premissas formuladas para estruturar o jogo são descritas a seguir.

Caso uma empresa $\mathbf{E}$ ofereça um produto de alta qualidade, receberá $p_{i}-Z_{i}$ e o consumidor $\mathbf{C}$ perceberá um valor $\mathrm{V}_{\mathrm{i}}-\mathrm{p}_{\mathrm{i}}$ caso opte pela compra do produto. Em outra situação, na qual a empresa ofereça um produto de baixa qualidade, o consumidor, ao adquirir o produto i, recebe um valor $v_{i}-p_{i}$ e a empresa $p_{i}-z_{i}$. Mesmo que a empresa ofereça alta qualidade e baixa qualidade, caso o consumidor $\mathbf{C}$ não compre o produto, ambos receberão zero ${ }^{33}$.

\section{Empresa $\mathbf{E}$}

\begin{tabular}{|c|c|c|}
\hline & Oferta Alta Qualidade & Oferta Baixa Qualidade \\
\hline Compra & $V_{i}-p_{i}, p_{i}-Z_{i}$ & $v_{i}-p_{i}, p_{i}-z_{i}$ \\
\hline Compra & 0,0 & $0,0_{i}$ \\
\hline
\end{tabular}

Figura 7. Payoff entre empresa "E" e consumidor "C"

Portanto, avaliando os payoffs ${ }^{34}$ entre o consumidor e a empresa $(\mathbf{C}, \mathbf{E})$, o único equilíbrio de Nash ocorre em uma situação que é Pareto inferior se o jogo for jogado uma única vez. $O$ equilíbrio se dá quando a empresa oferece baixa qualidade e, nesse caso, o consumidor não compra o produto (Figura 7). Como a qualidade não é percebida pelo consumidor, o jogo pode ser visto de forma simultânea, ou seja, o consumidor não vê a movimentação da empresa.

\footnotetext{
31 O Estado não é propriamente um "jogador" no modelo porque sua atuação se resume a uma movimentação aleatória ou "da natureza".

32 "O ponto de vista teórico do jogo é mais útil em um grupo pequeno de jogadores. Para eles, cada escolha dos jogadores é mais provavelmente importante para seu oponente" (Fudenberg e Tirole, 2002, p. xviii).

${ }_{33}$ Para facilitar o jogo, poderíamos supor que, embora haja um custo para a empresa produzir o produto com baixa (-z) e alta (-Z) qualidade, este pode ser oferecido em outro mercado ou destinado a outra finalidade, ou seja, não existe sunk costs que "são pagamentos realizados previamente na compra de ativos não recuperáveis" (Douglas, 1992, p. 293). Isso só ocorrerá no movimento intermediário do jogo (stage game) e, portanto, não influencia o equilíbrio final do jogo.

${ }^{34} \mathrm{Na}$ teoria do jogo (game theory), medida do valor de um resultado do jogo para quem participa.
} 


\section{Introduzindo a regulação}

Para aumentar o bem-estar, seria desejável, então, que o equilíbrio do jogo ocorresse na estratégia de "compra" por parte do consumidor $\mathbf{C}$ e na estratégia de oferta de produto de "alta qualidade" pela empresa E. Para isso, supomos a presença de um órgão regulador, o Estado. Seja $\mathbf{R}$ esse órgão regulador, $\mathbf{s}$ a probabilidade do agente regulador detectar a fraude. Seja a fraude definida como a oferta do atributo abaixo do nível de qualidade regulamentada pela norma vigente. Assumimos que o regulador $\mathbf{R}$, por meio de um mecanismo formal de fiscalização e monitoramento $\mathbf{f}_{\mathrm{i}}$, possa detectar com uma probabilidade $\mathbf{s}$ e não detectar com uma probabilidade (1-s) a oferta de um produto i de baixa qualidade por uma empresa $\mathbf{E}$.

Embora possa haver problemas com a qualidade do produto da empresa $\mathbf{E}$, que oferece alta qualidade, devido à impossibilidade de garantir cem por cento de segurança, a adoção, por parte da empresa, de práticas que permitam um maior nível de segurança do alimento ${ }^{35}$, impedem que ela seja autuada, não sendo, portanto, este payoff considerado no modelo, já que a probabilidade de s seria nula e de (1-s) igual a um. Caso a empresa E seja descoberta pelo órgão regulador $\mathbf{R}$ que ela oferta produto com baixa qualidade, ela receberá um multa $\mathbf{m}$. Nesse caso, teremos a estrutura de payoff ilustrada na Figura 8.

\section{Empresa $\mathbf{E}$}

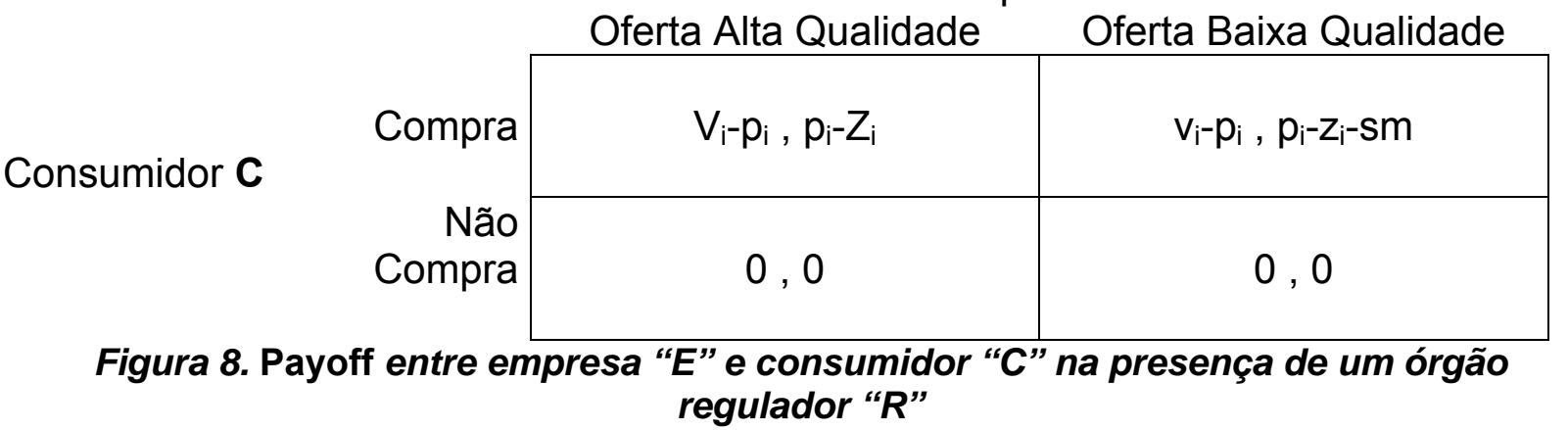

Se $z_{i}+s m \geq Z_{i}$ (ou $s m \geq Z_{i}-Z_{i}$ ), ou seja, a eficiência do mecanismo formal (probabilidade de detectar a má qualidade do produto multiplicado pelo valor da multa) tem que ser maior que a diferença entre o custo de se produzir com alta qualidade menos o custo de se produzir

\footnotetext{
${ }^{35}$ Como, por exemplo, a Análise de Perigos e Pontos Críticos de Controle (APPCC). A adoção do APPCC pela indústria de produção de alimentos já pode ser utilizada em alguns países como, por exemplo, os Estados
} 
com baixa qualidade, o equilíbrio de Nash se dará pela compra do produto pelo consumidor C, e a empresa E entregará alta qualidade, ocorrendo, então, uma situação de bem-estar desejada. Mas se $s m<Z_{i}-Z_{i}$ o consumidor e a empresa vão ter que se valer de outro mecanismo para atingir o resultado de Pareto superior, pois os incentivos via regulação serão ineficientes.

\section{Introduzindo reputação}

Um desses mecanismos é o mecanismo informal que gera reputação. Suponha-se, agora, que a empresa $\mathbf{E}$ e o Consumidor $\mathbf{C}$ transacionem repetidamente e os payoffs futuros sejam ajustados de acordo com um fator de desconto $\delta$. Esse fator pode ter diversas interpretações. Pode ser considerado como, por exemplo, um indicador do grau com que o consumidor $\mathbf{C}$ e a empresa $\mathbf{E}$ interagem no futuro ou grau de freqüência de compra. Segundo Overgaard (1990, p. 4), o problema de risco moral (moral razard) ${ }^{36}$, pode surgir da ignorância do consumidor sobre a escolha de qualidade do produtor em cada estágio ou data, ainda que por argumentos tradicionais. A repetição infinita da interação estratégica é necessária para garantir que a eficiência do mercado (uma alta qualidade do produto) possa ser suportada pela perfeita (portanto seqüencial) estratégia de equilíbrio.

O suprimento de qualidade alta será parte do equilíbrio perfeito do subjogo repetido (ABREU ${ }^{37}, 1988$ e BURGUET, 1996) se, i.e.:

$$
\frac{p_{i}-Z_{i}}{(1-\delta)} \geq p_{i}-z_{i}-s m+\delta 0+\delta^{2} 0+\ldots \delta^{n} 0
$$

onde $\mathrm{p}_{\mathrm{i}}, \mathrm{z}_{\mathrm{i}}$ e $\mathrm{m}$ já foram definidos e $\delta$ representa o fator de desconto (ou efeito reputação). Essa inequação (1) equivale a:

$$
\delta \geq \frac{\left(Z_{i}-z_{i}-s m\right)}{\left(p_{i}-z_{i}-s m\right)}
$$

\footnotetext{
Unidos, como uma salvaguarda a possíveis ações judiciais caso ocorra a contaminação do seu produto, já que não é possível garantir cem por cento de segurança do alimento.

${ }^{36}$ Segundo Kreps (1990, p. 577) o "problema do risco moral ocorre quando uma parte de uma transação pode empreender certas ações que (a) afetam a avaliação da transação pela outra parte, mas que (b) a outra parte não pode não pode monitorar perfeitamente".

37 "Apresenta uma estrutura para estudar os jogos de teoria dos jogos com descontos".
} 
Para simplificar a análise, normalize-se $p_{i}=1$; $\log Z_{i}<1$ pois $\left(1-Z_{i}\right)$ seria a margem de venda do produto i. Denote $F=s m_{i}$ ou o nível esperado de penalidade. Assuma $z_{i}=0$, ou seja, a empresa gasta nada com qualidade ou gasta $Z_{\mathrm{i}}$. Logo, (2) ficaria:

$$
\delta \geq \frac{\left(Z_{i}-F\right)}{(1-F)}
$$

Partindo para uma análise de como o equilíbrio varia, de acordo com os parâmetros do jogo, teremos a situação descrita na Figura 9 se assumirmos $Z_{i}=1 / 2$. Com base nas inequações (3), ilustrada pela reta $A B ; F>Z_{i}^{38}$, ilustrada pela reta $C B$ e $\delta>F$, ilustrada pela reta $A D$, podemos resolver o jogo e verificar as combinações das variáveis que culminam em um equilíbrio: o consumidor compra e a empresa oferece alta qualidade.

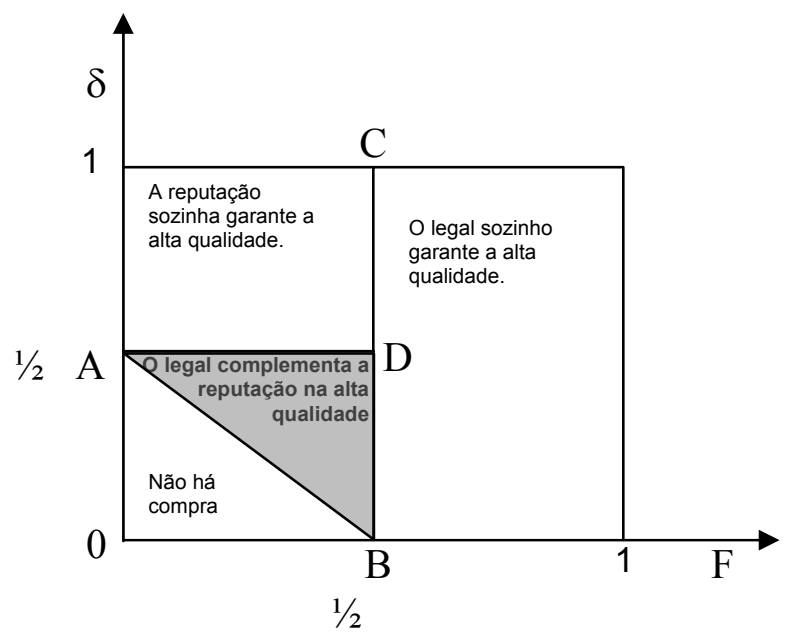

Figura 9. Equilíbrio para $Z_{i}=1 / 2$, de acordo com diferentes níveis de $F$ e $\delta$

À medida que o valor de $\delta$ aumenta, ou seja, o valor do ganho futuro é maior do que $1 / 2$, a reputação ou mecanismo informal, sozinho, garante a alta qualidade, desde que o mecanismo formal seja menor do que $1 / 2$. Um nível de alto de $\delta$ significa que as transações entre consumidor e empresa ocorrem várias vezes. Nesse caso, a empresa terá o incentivo para aumentar o valor percebido pelo consumidor ao investir em comunicação e marca para sinalizar a qualidade do produto. Essa expectativa de ganhos futuros ocorre independente da presença de um órgão regulador cuja eficiência é menor do que 1/2.

Já a norma ou mecanismo formal substitui o mecanismo informal, garantindo o equilíbrio desejado, sempre que $F$ for maior do que $1 / 2$. A partir desse valor, a eficiência da fiscalização já proporciona um valor percebido suficientemente alto para que o consumidor 
se decida pela compra. Do ponto de vista da empresa, existe o incentivo para que ela ofereça a alta qualidade do produto, caso contrário, seu retorno é reduzido devido à aplicação da penalidade imposta pelo órgão regulador. Caso $\mathrm{F}$ seja menor do que $1 / 2$, desde que $\delta$ seja igual a $1 / 2$, a complementaridade entre os mecanismos formal e informal ocorrerá. Nesse nível, tanto a empresa como o órgão regulador, precisam atuar de maneira conjunta para que a compra ocorra. Se $F$ ou $\delta$ forem, simultaneamente, menores do que $1 / 2$, a compra não se efetivará já que a inequação (3) não será respeitada, ou seja, a empresa não tem retorno desejável e o consumidor não tem condições de gerar um valor percebido de qualidade suficiente para se decidir pela compra.

É importante notar que, em todos os casos, a não compra também pode ser um resultado de equilíbrio do subjogo, fazendo parte do equilíbrio de Nash do jogo não repetitivo. Logo, repetição não é suficiente para se alcançar a alta qualidade. A presença de muitos produtos substitutos e da renda baixa do consumidor seriam alguns exemplos.

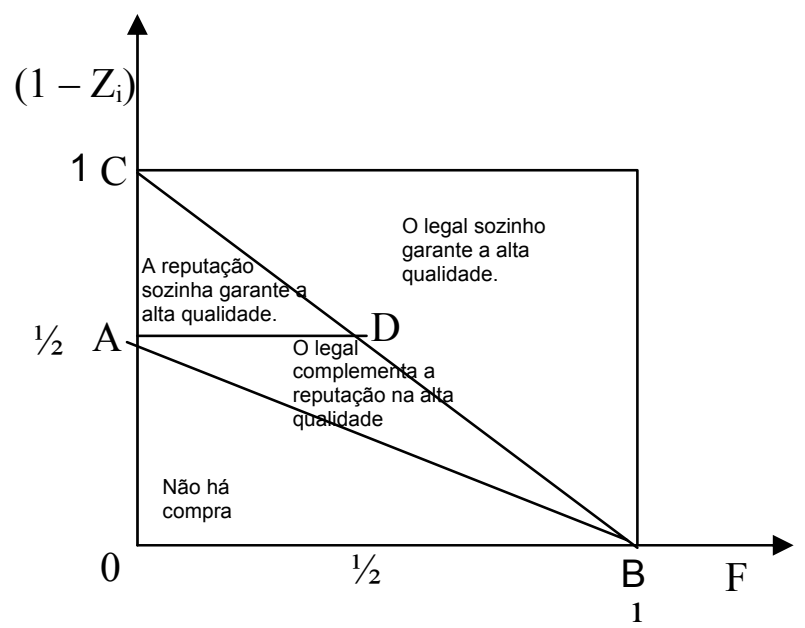

Figura 10. Equilíbrio para $\delta=1 / 2$, de acordo com diferentes níveis de F e (1-Z)

Pode-se buscar a variabilidade, também em $Z_{i}$, para verificar como a margem, ou prêmio recebido pela empresa, afeta a relação. Se fixarmos $\delta=1 / 2$, para uma simulação com $\left(1-Z_{i}\right)$, considerado como a margem de venda, teremos as combinações ilustradas na Figura 10. Neste caso, quanto maior for a margem de venda $\left(1-Z_{i}\right)$ da empresa, mais o mecanismo informal garantirá a alta qualidade.

\footnotetext{
${ }^{38}$ Sabemos que, se $\mathrm{sm}=\mathrm{F} \geq \mathrm{Z}_{\mathrm{i}}$, a regulamentação sozinha garante o suprimento de alta qualidade.
} 


\section{O papel da marca}

$\mathrm{Na}$ abordagem de Klein e Leffer (op.cit, 1981), a marca serve para evitar a entrada de competidores, uma vez que impõe custos irrecuperáveis à entrada em certo mercado. Caso contrário, não haveria prêmio $\left(\mathrm{p}_{\mathrm{i}}-\mathrm{Z}_{\mathrm{i}}\right)$, ele seria "arbitrado".

A marca pode "sinalizar" qualidade em uma situação em que o consumidor poderia formar expectativas sobre o produto por meio de uma estratégia de comunicação e propaganda da empresa (TIROLE, 2002. p. 107-108). Se a firma vende o produto com mais propaganda, um preço maior é necessário para que a qualidade seja garantida ${ }^{39}$ (KLEIN e LEFFLER, op. cit, p. 632). Já segundo Horstmann e MacDonald (1994, p. 578), nem o preço introdutório, nem a propaganda, servem como sinais da qualidade do produto.

No momento da decisão do consumidor, em muitos casos, a qualidade do produto não é conhecida até que ele seja consumido ou, por problemas de percepção, seja difícil estabelecer-se a reputação. Produtores de bens de alta qualidade podem sinalizar os benefícios por meio da propaganda antes do momento da compra (WEIGELT e CAMERER, 1988, p. 448), Um $\delta$ baixo significa que a empresa ou produto tem uma "miopia" em obter lucro rapidamente. As empresas que têm $\delta$ alto realizaram investimentos irrecuperáveis por meio da propaganda, ajudando o consumidor a formar expectativas.

Assumimos que a marca ou o selo de qualidade seja um mecanismo informal que pode facilitar a percepção da baixa ou alta qualidade do produto caso gerem reputação e recompra. O conceito de lealdade à marca é assumido, aqui, como sendo uma proxi para mensurar o fator de desconto $\delta$. Como visto no capítulo três, segundo Chaudhuri e Holbrook (2001, op. cit.), a lealdade à marca pode ser mensurada em relação à sua confiança (brand trust) e afeto (brand affect).

Como $\delta$ não é diretamente observável ${ }^{40}$, utilizaremos o "conhecimento sobre a marca" para medi-lo. Embora não diretamente relacionada à possibilidade de repetição da transação, a marca informa a procedência do produto e, com isso, o consumidor terá a possibilidade de relacionar e realizar novamente a compra ou transação pela intensidade de conhecimento e

\footnotetext{
${ }^{39}$ Kao e Smith (1993) também avaliam o papel de diferentes tipos de garantia como forma de incentivo à compra repetitiva.

${ }^{40}$ Futuras pesquisas podem ser direcionadas no sentido de mensurar seu valor.
} 
expectativas que tem sobre ela (WANSINK e RAY, op. cit). O capítulo a seguir apresenta o método proposto para a mensuração e a análise dos parâmetros deste modelo. 


\section{V - METODOLOGIA}

O procedimento metodológico deu-se pela aplicação de um experimento econômico em que as variáveis de interesse foram controladas de modo a permitir testar as hipóteses do modelo desenvolvido no capítulo anterior. Inicialmente, são descritos os procedimentos e cuidados adotados para a escolha da amostra; em seguida, o método de coleta e, por fim, os métodos de análise utilizados.

\subsection{População e planejamento amostral}

A população da pesquisa foi composta por três agentes econômicos: (1) empresas de varejo que comercializam a carne bovina; (2) seus respectivos consumidores abordados em um mesmo momento da pesquisa de campo e em seu domicílio; (3) os principais órgãos públicos reguladores responsáveis pela definição e monitoramento dos mecanismos formais de garantia da segurança e da qualidade em alimentos: a vigilância sanitária e o ministério da agricultura. Devido à limitação de tempo e recurso, os três tipos de organizações classificadas de acordo com os procedimentos adotados, manipulação empregada e 
natureza do produto processado, o matadouro ${ }^{41}$, matadouros-frigoríficos ${ }^{42}$ e frigoríficos processadores $^{43}$ não serão pesquisados (SILVA e BATALHA, op. cit, p. 226).

A pesquisa foi conduzida no município de Piracicaba, localizado no interior do Estado de São Paulo distante $145 \mathrm{~km}$ da capital. Com cerca de 328 mil habitantes, sua economia é multidiversificada e está fortemente baseada na produção agrícola e industrial, com destaque para os setores sucroalcooleiro e metal-mecânico (PIRACICABA, 2003).

Dois tipos distintos de estabelecimentos que comercializam carne foram pesquisados: o açougue $^{44}$ e o supermercado ${ }^{45}$. Embora existam outros pontos de venda, estes não foram abordados: as casas de carnes, por se tratar de uma situação intermediária entre a boutique de carne ${ }^{46}$ e o açougue, e as feiras-livres, por predominarem em regiões específicas como no norte e no nordeste (SILVA e BATALHA, 1999, p. 185).

Dada a limitação de tempo e recursos, foram pesquisados quinhentos e noventa e um consumidores, abordados aleatoriamente, nos locais definidos. Por meio de uma listagem fornecida pela Secretaria da Receita do município, foram apontados 157 estabelecimentos cadastrados como "açougue" e 94 estabelecimentos cadastrados como "hipermercado e supermercado". A amostragem foi baseada na divisão do município em regiões (Anexos $D$ ) e no número de estabelecimentos presentes em cada região (Anexo E).

\footnotetext{
41 "praticam o abate de bovino, e, não dispondo de instalações para congelamento, comercializam a carne in natura ou refrigerada para comerciantes da região imediatamente mais próxima. São providos de equipamentos e estrutura de baixa produtividade, mão-de-obra de baixa qualificação, e baixo controle sanitário. Os subprodutos são vendidos, principalmente para serem transformados em ração, com exceção do couro". (SILVA e BATALHA, op. cit., p. 226).

42 "são empresas que praticam o abate e possuem estrutura mais moderna e produtiva, possuindo instalações para congelamento, câmaras-frias, empregados melhor qualificados, comercializando produtos com osso in natura, e produtos in natura desossados, refrigerados e congelados. Manipulam os subprodutos a serem vendidos para consumo humano ou como fonte de matéria-prima de outras empresas". (SILVA e BATALHA, op. cit., p. 226).

43 "são empresas com tecnologias mais modernas e que demandam maiores investimentos, realizando o processamento da carne bovina; possuem mão-de-obra muito bem qualificada e melhor aproveitamento para os subprodutos". (SILVA e BATALHA, op. cit., p. 226).

44 "Os açougues são pontos de venda independentes ou fazem parte de redes com algumas filiais. São caracterizados como varejo tradicional, onde existe a presença de um vendedor (açougueiro ou ajudante) que corta, embala e orienta o cliente no momento da compra". (SILVA e BATALHA, 1999).

45 "Os super e hipermercados são o tipo de canal organizado sob o conceito de auto-serviço, onde o cliente encontra os produtos dispostos em gôndolas para sua escolha". (SILVA e BATALHA, op. cit., p. 183).

46 "São pontos de venda conhecidos pela venda de cortes especiais, normalmente embalados, dispostos em freezers e balcões frigoríficos. Podem ser de auto-serviço ou tradicionais, mas, mesmo no primeiro caso, dispõem de pessoas para orientarem o consumidor sobre características específicas dos produtos". (Silva e Batalha, op. cit., p. 184).
} 
Dado que a população é semelhante em cada região e o número de açougues é maior, localizados na sua maioria na região centro, foram selecionados, por conveniência, 29 açougues e 15 supermercados. Foram entrevistados 86 consumidores em açougues e 219 em supermercados.

Já o critério utilizado para selecionar as residências foi o de tomar, por conveniência, uma distância de cinco quarteirões de cada estabelecimento e entrevistar, aleatoriamente, dez consumidores, respectivamente, em dez diferentes residências. Foram entrevistados 286 consumidores em residências.

Por fim, para se caracterizar os mecanismos formais, foram pesquisados os órgãos responsáveis pelas políticas de segurança e qualidade do alimento, mais especificamente a secretaria municipal da vigilância sanitária e o Departamento de Inspeção de Produtos de Origem Animal (DIPOA) do Ministério da Agricultura e Abastecimento de São Paulo.

\subsection{Instrumentos e métodos de coleta}

A pesquisa com os consumidores de carne bovina foi realizada no entreposto de comercialização, açougue e supermercado, e em residências durante a segunda quinzena do mês de janeiro de 2003. Foram aplicados questionários (Anexo F) pelo pesquisador e por mais dez pesquisadores que receberam um treinamento prévio. Antes do início do procedimento de campo, um pré-teste foi conduzido por todos os pesquisadores e duas reuniões foram realizadas para a definição da estrutura do questionário final. Cada consumidor e cada estabelecimento foi entrevistado por uma dupla de pesquisadores para facilitar a coleta e evitar erros no preenchimento das informações.

A coleta de informações nos entrepostos de comercialização de carne bovina realizada por meio de questionário (Anexo $G$ ) o qual foi submetido a um pré-teste. Os órgãos públicos responsáveis pelas políticas de segurança do alimento foram pesquisados qualitativamente por intermédio de entrevista. 


\subsection{Método de análise conjunta}

Para se verificar, diretamente, a preferência dos consumidores em relação aos mecanismos foi utilizada a técnica de análise conjunta (conjoint analysis). Nesta técnica, são construídos produtos hipotéticos por meio da definição de atributos com diferentes níveis (GREEN e SRINIVASAN, 1978), que são importantes no processo de decisão de compra do consumidor. Esses produtos são apresentados ao consumidor para que este os ordene em termos de sua preferência. A Conjoint Analysis define funções individuais de preferência, que podem ser agregadas em grupos homogêneos de segmentos de consumidores por uma análise de conglomerados. Além disso, pode-se medir as indecisões do consumidor e as ponderações que realiza quanto aos riscos e aos benefícios de determinados atributos. $O$ método, também, permite, por meio dos resultados da amostra estudada, avaliar cenários mais complexos (SIQUEIRA, 1995), com diferentes níveis de mecanismos formais, informais e preços, por exemplo.

A Conjoint Analysis decompõe a utilidade individual por um produto ou serviço em uma determinada combinação de utilidades parciais definidas para características relevantes ou atributos de um produto. Isso significa que, para uma alternativa de escolha, descrita em termos de um conjunto de características ou atributos $a_{k}=\left(a_{1}, \ldots, a_{k}\right)$, a função utilidade para um indivíduo é especificada em termos de uma combinação de regras $W$ e um conjunto de formas funcionais $a_{k}$ (um para cada característica) como $W\left(w_{1}\left(a_{1}\right), \ldots, w_{k}\left(a_{k}\right)\right)$ onde: $W=$ utilidade em relação ao produto; $w_{k}=$ utilidade parcial sobre um atributo específico $k$ e; $a_{k}=$ valor do atributo específico $\mathrm{k}$.

O método baseia-se na premissa de que o consumidor avalia ou quantifica um produto, combinando quantidades separadas de utilidade proporcionadas por atributo. O pesquisador constrói um conjunto de produtos hipotéticos combinando atributos em vários níveis (BAKER e CROSBIE, 1993). Um produto hipotético é definido pela combinação de níveis dos atributos. Sob o ponto de vista experimental, os atributos do produto são os fatores; os produtos hipotéticos são os tratamentos e o conjunto de produtos hipotéticos, o delineamento experimental.

Os produtos hipotéticos são apresentados aos consumidores, que são questionados para informar sua avaliação geral a respeito dos produtos, em forma de ordenação de suas preferências, baseando-se na teoria econômica do consumidor. O método de Mínimos 
Quadrados Ordinários (HAIR et al, 1998, p. 420) ${ }^{47}$ é usado para estimar a função utilidade $W\left(w_{1}\left(a_{1}\right), \ldots, w_{k}\left(a_{k}\right)\right.$ para cada indivíduo, baseando-se em sua escala de preferência.

A seleção dos atributos do produto e de seus níveis afeta tanto a precisão como a relevância dos resultados. Sob uma perspectiva prática, é necessário limitar os atributos considerados para o estudo. Os níveis dos atributos selecionados precisam ser confiáveis e significativos para os respondentes. Em outras palavras, o nível descrito precisa ser o mais preciso possível e sua faixa não deve exceder grandemente os níveis existentes.

\section{Atributos definidos para a análise conjunta}

Analisando o papel das informações no processo decisório de compra de carne bovina na cidade de Porto Alegre, Barcellos e Callegaro (2002), entrevistaram 400 consumidores na cidade de Porto Alegre e, por meio de análise fatorial, reduziram as variáveis sobre informações da carne bovina a cinco fatores como indicadores de qualidade do produto (Tabela 3).

Tabela 3. Fatores referentes como indicadores de qualidade

\begin{tabular}{|c|c|c|c|}
\hline Fator & Nome & Variáveis & $\begin{array}{c}\text { Carga } \\
\text { Fatorial }\end{array}$ \\
\hline 1 & Informações sobre o animal & $\begin{array}{l}\text { Raça do animal } \\
\text { Idade do animal } \\
\text { Alimentação do animal } \\
\text { Sexo do animal } \\
\text { Origem/procedência }\end{array}$ & $\begin{array}{l}0,788 \\
0,765 \\
0,732 \\
0,717 \\
0,412 \\
\end{array}$ \\
\hline 2 & Fiscalização & $\begin{array}{l}\text { Registro de Inspeção Federal } \\
\text { Certificação de qualidade } \\
\text { Data do abate } \\
\text { Data de validade }\end{array}$ & $\begin{array}{l}0,762 \\
0,756 \\
0,659 \\
0,491\end{array}$ \\
\hline 3 & Informações sobre o produto & $\begin{array}{l}\text { Composição nutricional (kcal, proteínas) } \\
\text { Quantidade de gordura } \\
\text { Instruções de conservação e manuseio }\end{array}$ & $\begin{array}{l}0,829 \\
0,798 \\
0,553\end{array}$ \\
\hline 4 & Corte de carne & $\begin{array}{l}\text { Nome do corte } \\
\text { Preço do corte } \\
\text { Peso do corte }\end{array}$ & $\begin{array}{l}0,786 \\
0,771 \\
0,760 \\
\end{array}$ \\
\hline 5 & Marca & Marca & 0,900 \\
\hline
\end{tabular}

Fonte: BARCELLOS, Marcia Dutra de; CALLEGARO, Carlos Alberto Martins. A Importância da informação como indicador de qualidade: o caso da compra de carne bovina em Porto Alegre, 2002, p. 13.

Mantendo-se constantes as informações sobre o animal e o produto (Fatores 1 e 3 ) e em se escolhendo um tipo específico de carne (Fator 4), a estrutura de preferência do consumidor

\footnotetext{
${ }^{47}$ A técnica tem sido aprimorada com a utilização de outras técnicas de estimação (vide HAIR, 1998).
} 
poderia ser definida pelos atributos de fiscalização ou mecanismo formal (Fator 2) e a marca ou mecanismo informal (Fator 5).

Para se ter uma variabilidade considerável e identificar claramente o nível que está sendo analisado, três diferentes intensidades foram associadas aos atributos. Devido ao fato de a marca não estar diretamente associada ao modelo e, sim, à repetição da transação, foi utilizado o nível alto, médio e baixo de conhecimento sobre a marca, assumindo que o consumidor tem a oportunidade de repetir a transação, se tiver condições de identificar o produto. O nível baixo foi associado à "inexistência da marca", o nível médio à "marca desconhecida" e o nível alto à "marca conhecida".

Os níveis alto, médio e baixo de fiscalização foram definidos respectivamente como "fiscalização intensiva", "fiscalização esporádica" e "ausência de fiscalização". O atributo preço foi incluído para analisar a interação entre preço e fiscalização. Os níveis de preço alto, médio e baixo foram definidos respectivamente por $R \$ 16,00, R \$ 12,00$ e $R \$ 8,00$. Esses valores foram baseados em um levantamento realizado em três supermercados de Piracicaba em janeiro de 2003. O Anexo H mostra a relação de preços entre dois tipos de carnes não embaladas e sem marca em três diferentes estabelecimentos do município.

Caso mais níveis ou atributos sejam incorporados ao modelo, é preciso a construção da função agregada de preferência individual. Para um completo delineamento fatorial, com três atributos (mecanismo formal, mecanismo informal e preço) com três níveis cada (alto, médio e baixo), seria necessária a construção de 27 produtos hipotéticos, o que tornaria o experimento impraticável devido à dificuldade de ordenação pelo consumidor. Portanto, uma matriz ortogonal ${ }^{48}$ foi gerada com base na projeção fracional fatorial, para que o número de produtos hipotéticos seja reduzido. Neste estudo, nove produtos foram gerados a partir da matriz ortogonal ${ }^{49}$ (Anexo I). É importante salientar que os produtos foram mostrados ao consumidor aleatoriamente e que, no estímulo, palavras consideradas "fortes" como "reputação" não foram utilizadas, atribuindo-se aos três diferentes níveis as expressões alta, média e baixa. Caso o consumidor perguntasse sobre o significado dos níveis, informações adicionais eram disponibilizadas (Tabela 4).

\footnotetext{
48 "Cada nível do fator aparece combinado com cada nível de todos os outros fatores num número igual de vezes ou numa proporção constante" (PERCEPTUAL, 1993, p.1-2)

${ }^{49}$ Para a geração da matriz foi utilizado o aplicativo Statistical Package for Social Science (SPSS) versão 11.0.
} 
Tabela 4. Atributos e seus respectivos níveis definidos para a análise conjunta

\begin{tabular}{|c|c|c|c|}
\hline Níveis & Preço & Intensidade da Fiscalização & $\begin{array}{c}\text { Conhecimento sobre a } \\
\text { marca }\end{array}$ \\
\hline Baixo & $\mathrm{R} \$ 8,00$ & $\begin{array}{l}\text { Ausência do selo do SIF. Leis que não garantam que o } \\
\text { estabelecimento de comercialização e produção de carne } \\
\text { bovina seja punido em caso de se detectar a } \\
\text { contaminação da carne ou práticas de higiene } \\
\text { inadequadas que comprometam a segurança do produto. } \\
\text { Sem visitas dos agentes da vigilância sanitária. }\end{array}$ & $\begin{array}{l}\text { A carne não é embalada e não existe } \\
\text { a identificação de nenhuma marca. }\end{array}$ \\
\hline Médio & $\mathrm{R} \$ 12,00$ & $\begin{array}{l}\text { Presença do selo do SIF. Leis que punam } \\
\text { moderadamente o estabelecimento de comercialização e } \\
\text { produção de carne bovina em caso de se detectar a } \\
\text { contaminação da carne ou utilização de práticas de } \\
\text { higiene inadequadas que comprometam a segurança do } \\
\text { produto. Visitas esporádicas dos agentes da vigilância } \\
\text { sanitária. }\end{array}$ & $\begin{array}{l}\text { A carne é embalada e existe o nome } \\
\text { da marca na embalagem. Você } \\
\text { desconhece a marca e não consumiu } \\
\text { nenhum outro produto com essa } \\
\text { marca. }\end{array}$ \\
\hline Alto & $\mathrm{R} \$ 16,00$ & $\begin{array}{l}\text { Presença do selo do SIF. Leis que punam exemplarmente } \\
\text { o estabelecimento de comercialização e produção de } \\
\text { carne bovina em caso de se detectar a contaminação da } \\
\text { carne ou utilização de práticas de higiene inadequadas } \\
\text { que comprometam a segurança do produto. Visitas } \\
\text { periódicas de agentes da vigilância sanitária. }\end{array}$ & $\begin{array}{l}\text { A carne é embalada e existe o nome } \\
\text { da marca na embalagem. Você } \\
\text { conhece a marca pelo consumo da } \\
\text { carne em outras oportunidades ou já } \\
\text { consumiu outros produtos com essa } \\
\text { marca. }\end{array}$ \\
\hline
\end{tabular}

\section{Análise das preferências}

Foram apresentados aos consumidores os nove produtos hipotéticos, no caso, carnes consideradas de primeira, construídos a partir de diferentes combinações de níveis de preço e mecanismos formais e informais. Foi solicitado que expressassem a sua utilidade indiretamente, por meio da ordenação dos produtos, com base na sua preferência por aqueles que proporcionam uma maior percepção de qualidade.

A regra de combinação, $W$, para a função de utilidade é genericamente uma escolha entre o modelo aditivo e o quadrático. Um modelo aditivo capta somente os principais efeitos dos atributos, enquanto a forma quadrática capta os efeitos das interações entre os atributos. Incluir os efeitos das interações, geralmente, não aumenta o poder preditivo do modelo por duas razões principais. Primeiramente, há uma perda na eficiência estatística à medida que mais parâmetros são estimados. A segunda razão é a necessidade de aumentar o número de produtos hipotéticos apresentados ao consumidor, à medida que o número de parâmetros a estimar aumenta, dificultando a prática experimental de campo. Por isso, o modelo mais comum é o aditivo.

As formas funcionais para as utilidades individuais das características do produto, $w_{1}\left(a_{1}\right)$ são geralmente selecionadas de um conjunto de três tipos: linear, quadrático ou "part-worth". O linear ou modelo vetorial, $w_{1}\left(a_{1}\right)=b a_{k}$, onde $b$ é a utilidade por unidade do atributo $a_{k}$, é $a$ 
escolha mais restritiva. O modelo de "part-worth" $w_{1}\left(a_{1}\right)=w_{a k}$ estima um nível de utilidade particular para cada nível de atributo e é a escolha mais flexível; por isso foi o escolhido neste estudo. $O$ modelo quadrático ou ponto ideal $w_{1}\left(a_{1}\right)=c\left(a^{*}-a_{k}\right)^{2}$, onde $a^{*}$ é o nível ideal do atributo para o consumidor e $\mathrm{c}$, a constante de proporcionalidade, permite uma relação curvilínea entre níveis de atributos. A escolha da forma funcional depende do relacionamento entre os diferentes níveis do atributo em particular. A mistura de modelos entre os atributos dos produtos pode ser realizada.

Com o intuito de complementar as análises pela técnica conjunta, informações complementares foram direcionadas à mesma amostra para possibilitar, por meio de uma análise de conglomerados, segmentos homogêneos de consumidores com base em suas características sociais e comportamentais. Como é impossível colocar todos os fatores da decisão de compra, o foco se deu em aspectos públicos e privados que podem diminuir ou aumentar a percepção de qualidade sobre a garantia da segurança dos produtos.

\subsection{Método de análise: os modelos de regressão ordered probit e poisson}

Os modelos de regressão discreta são aqueles nos quais a variável dependente assume valores discretos (MADDALA, 1990, p. 13). O modelo denominado ordered probit é construído sobre uma regressão latente da mesma maneira que o modelo binominal probit (GREENE, 2003, p. 736). Existem, na literatura, alguns exemplos que mesclam a técnica conjunta com o modelo de ordered probit. "O modelo random effects ordered probit resulta em uma situação em que todos coeficientes e valores marginais são significativamente diferentes de zero. Se isto gerar um ganho em termos de eficiência estatística, sugere que o efeito de painel deva ser incorporado a futuras pesquisas de análise conjunta e pode permitir aos pesquisadores economizar no tamanho da amostra e evitar as inferências enganosas sobre o valor marginal dos atributos" (HAEFELE e LOOMIS, 2001, p. 1326).

Rivera (2001) aplica o modelo de ordered probit para analisar a relação entre gasto público com saúde, com base na própria ordenação da avaliação da condição de saúde do entrevistado: excelente, boa, regular, ruim e muito ruim. Dennis (2000), avalia as preferências públicas por meio de uma pesquisa de ordenação conjunta que avalia vários níveis de colheita de madeira, vida selvagem, trilhas, pistas de neve, acesso por veículo a 
um determinado parque. Neste caso, o modelo ordered probit e a técnica discreta de escolha logit foram utilizados para estimar o efeito linear e quadrático destes atributos.

No caso da variável dependente assumir valores discretos, não categóricos, e no caso de termos dados sobre outra variável explanatória para cada observação (e nosso interesse central é o efeito de cada uma destas variáveis exploratórias sobre a variável explicativa) é utilizada a regressão Poisson (MADDALA, op. cit., p. 51). Como estamos interessados, apenas, nas magnitudes das interações captadas por meio dos coeficientes, ambos os modelos podem ser utilizados.

Para analisar a relação de complementaridade entre marca e fiscalização em que o preço é mantido constante, tanto o modelo de regressão random-effects poisson quanto o de ordered probit, foram utilizados com base na seguinte relação:

$$
y_{i j}=\beta^{\prime} x_{i j}+p_{i j}+p_{i j}{ }^{2}+u_{i j}
$$

Onde $\mathbf{y}_{\mathrm{j}}$ é a ordenação do consumidor em termos do produto que oferece uma menor para uma maior percepção de qualidade. Varia de um a nove respectivamente para uma menor percepção de alta qualidade ( $\mathbf{y}_{\mathbf{j}}$ igual a um) para uma maior percepção de alta qualidade $\left(\mathbf{y}_{\mathbf{j}}\right.$ igual a nove). O vetor $\boldsymbol{\beta}$ ' é composto pelos regressores para as nove combinações entre marca e fiscalização, sendo a probabilidade do produto $i(i=1 . . .9)$ igual a um se foi escolhido em determinada ordem $\mathbf{y}_{\mathbf{j}}$ ou zero caso contrário. A variável de controle $\mathbf{p}$ mede a os níveis da marca do produto. Oito se for preço baixo ( $p b$ ou $\mathrm{R} \$ 8,00$ ), doze se for preço médio (pm ou $R \$ 12,00$ ) e três se for preço alto (pa ou $R \$ 16,00$ ). A variável de controle $p^{2}$ foi incluída para verificar o efeito quadrático.

No caso do modelo ordered probit, sendo $\mu_{\mathrm{ik}}$ os valores que definem os limites dos intervalos das utilidades que correspondem a resposta ordinal observada e assumindo que o erro $\varepsilon_{\mathrm{ij}}$ tem distribuição normal, a variável observada ( $Y_{i j}$, a ordenação para as $\mathrm{J}$ alternativas) é relacionada com a utilidade não observada $\left(U_{i j}\right)$ da seguinte maneira:

$$
Y_{i j}=0 \text { se } U_{i j}<\mu_{i 1}, Y_{i j}=1 \text { se } \mu_{i 1}<U_{i j}<\mu_{i 2}, \ldots Y_{i j}=J-1 \text { se } U_{i j}<\mu_{i J}-1
$$

A hipótese $\mathrm{H}_{\mathrm{A}}$ e hipótese $\mathrm{H}_{\mathrm{B}}$, formuladas para avaliar a complementaridade entre marca $\mathrm{e}$ fiscalização, mantendo-se o preço constante, é testada pela diferença entre o aumento da intensidade de mudança na percepção do consumidor, em função de um aumento exclusivo 
do conhecimento sobre a marca e a intensidade de fiscalização em relação a um aumento conjunto destas variáveis (Figura 11).

\begin{tabular}{|c|c|c|c|}
\hline $\begin{array}{r}\delta \text { alto ou marca de carne } \\
\text { conhecida }\end{array}$ & + & $\begin{array}{c}+ \\
\text { Substitutos }\end{array}$ & Complementares \\
\hline $\begin{array}{r}\delta \text { médio ou marca de carne } \\
\text { desconhecida }\end{array}$ & $\begin{array}{c}+ \\
\text { Substitutos }\end{array}$ & ${ }_{\text {Complementares }}^{++}$ & $\begin{array}{c}+ \\
\longrightarrow \text { Substitutos }\end{array}$ \\
\hline $\begin{array}{r}\delta \text { baixo ou carne sem } \\
\text { marca }\end{array}$ & 0 & $\stackrel{+}{+}$ Substitutos & + \\
\hline & $\begin{array}{l}\mathrm{F} \text { baixo ou sem } \\
\text { fiscalização }\end{array}$ & $\begin{array}{c}\text { F médio ou } \\
\text { fiscalização esporádica }\end{array}$ & $\begin{array}{c}\text { F alto ou fiscalização } \\
\text { intensa }\end{array}$ \\
\hline
\end{tabular}

Figura 11. Análise da hipótese Ha e $\mathrm{Hb}$

A hipótese $\mathrm{H}_{\mathrm{C}}$, formulada para avaliar a complementaridade entre marca e fiscalização entre dois níveis diferentes, mantendo-se o preço constante, é testada pela diferença entre a intensidade de mudança na percepção do consumidor nos níveis baixo a médio e médio a alto (Figura 12).

\begin{tabular}{|c|c|c|c|}
\hline $\begin{array}{r}\delta \text { alto ou marca de carne } \\
\text { conhecida }\end{array}$ & + & + & $\begin{array}{l}\text { ++ (intensidade) } \\
\text { Complementares }\end{array}$ \\
\hline $\begin{array}{r}\delta \text { médio ou marca de carne } \\
\text { desconhecida }\end{array}$ & + & $\begin{array}{l}\text { ++ (intensidade) } \\
\text { Complementares }\end{array}$ & + \\
\hline$\delta$ baixo ou carne sem marca & 0 & + & + \\
\hline & $\begin{array}{l}\mathrm{F} \text { baixo ou sem } \\
\text { fiscalização }\end{array}$ & $\begin{array}{l}\text { F médio ou } \\
\text { fiscalização } \\
\text { esporádica }\end{array}$ & $\begin{array}{c}\text { F alto ou fiscalização } \\
\text { intensa }\end{array}$ \\
\hline
\end{tabular}

Figura 12. Teste da hipótese Hc

Para analisar a relação de complementaridade entre preço e fiscalização, em que a intensidade do conhecimento sobre a marca é mantida constante, o modelo random-effects poisson e o modelo de ordered probit foram utilizados:

$$
y_{i j}=\beta^{\prime} x_{i j}+m_{i j}+m_{i j}^{2}+u_{i j}
$$

Onde $y_{j}$ é a ordenação do consumidor em termos do produto que oferece uma maior percepção de qualidade. Varia de um a nove respectivamente para uma menor percepção de alta qualidade (igual a um) para uma maior percepção de alta qualidade (igual a nove). $O$ vetor $\beta$ ' são os regressores para as nove combinações entre preço e fiscalização, sendo a probabilidade do produto $\mathrm{i}\left(\mathrm{i}=1 \ldots 9\right.$ ) igual a um, se foi escolhido em determinada ordem $\mathbf{y}_{\mathrm{j}}$ ou zero caso contrário. A variável de controle $\mathrm{m}$ mede a intensidade da marca do produto. Um, se for marca de intensidade baixa (Mb ou sem marca); dois, se for marca de intensidade 
média (Mm ou marca desconhecida) e três, se for marca de intensidade alta (Ma ou marca conhecida). A variável de controle $\mathrm{m}^{2}$ foi incluída para verificar o efeito quadrático.

\begin{tabular}{|c|c|c|c|}
\hline $\begin{array}{r}\text { (1-Z) alto ou preço da carne } \\
\text { a } R \$ 16,00\end{array}$ & + & $\underset{\text { Substitutos }}{+} \uparrow$ & ${ }^{++}$Complementares \\
\hline $\begin{array}{r}\text { (1-Z) médio ou preço da } \\
\text { carne a } \mathrm{R} \$ 12,00\end{array}$ & $\begin{array}{c}+ \\
\text { Substitutos }\end{array}$ & $\bigwedge_{\text {Complementares }}^{++}$ & $\rightarrow \stackrel{+}{ }+$ Substitutos \\
\hline $\begin{array}{r}\text { (1-Z) baixo ou preço da } \\
\text { carne a } R \$ 8,00\end{array}$ & 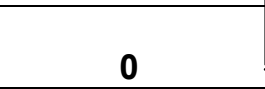 & $\begin{array}{c}+ \\
\rightarrow \\
\text { Substitutos }\end{array}$ & 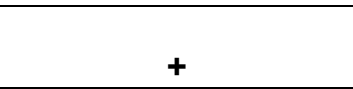 \\
\hline & $\begin{array}{l}\text { F baixo ou sem } \\
\text { fiscalização }\end{array}$ & $\begin{array}{l}\mathrm{F} \text { médio ou } \\
\text { fiscalização } \\
\text { esporádica }\end{array}$ & $\begin{array}{c}\text { F alto ou fiscalização } \\
\text { intensa }\end{array}$ \\
\hline
\end{tabular}

Figura 13. Teste da hipótese $\mathrm{Hd}$ e He

As hipóteses $H_{D}$ e $H_{E}$, formulada para avaliar a complementaridade entre preço e fiscalização, mantendo-se o conhecimento sobre a marca constante, é testada pela diferença entre a intensidade de mudança na percepção do consumidor com um aumento exclusivo do preço e a intensidade de fiscalização em relação a um aumento conjunto destas variáveis (Figura 13).

\begin{tabular}{|c|c|c|c|}
\hline $\begin{array}{r}\text { (1-Z) alto ou preço da carne } \\
\text { a } R \$ 16,00\end{array}$ & + & + & $\begin{array}{l}\text { ++ (intensidade) } \\
\text { Complementares }\end{array}$ \\
\hline $\begin{array}{r}\text { (1-Z) médio ou preço da } \\
\text { carne a } \mathrm{R} \$ 12,00\end{array}$ & + & $\begin{array}{l}\text { ++ (intensidade) } \\
\text { Complementares }\end{array}$ & 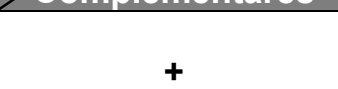 \\
\hline $\begin{array}{r}\text { (1-Z) baixo ou preço da } \\
\text { carne a } R \$ 8,00 \\
\end{array}$ & 0 & + & + \\
\hline & $\begin{array}{l}\mathrm{F} \text { baixo ou sem } \\
\text { fiscalização }\end{array}$ & $\begin{array}{l}\text { F médio ou } \\
\text { fiscalização } \\
\text { esporádica }\end{array}$ & $\begin{array}{c}\text { F alto ou fiscalização } \\
\text { intensa }\end{array}$ \\
\hline
\end{tabular}

Figura 14. Teste da hipótese $\mathrm{Hf}$

A hipótese $H_{F}$, formulada para avaliar a complementaridade entre preço e fiscalização em diferentes níveis, mantendo-se o conhecimento sobre a marca constante, é testada pela diferença entre a intensidade de mudança na percepção do consumidor nos níveis baixo a médio e médio a alto (Figura 14).

O capítulo seguinte relata os resultados obtidos com a aplicação desta metodologia de coleta e análise proposta. 


\section{VI - RESULTADOS E DISCUSSÃO}

Uma amostra de $15 \%$ dos estabelecimentos, três supermercados e três açougues; e $5 \%$ de consumidores, trinta entrevistados, foram escolhidos aleatoriamente e contatados por telefone para a verificação da realização da entrevista e das informações coletadas.

Em relação aos consumidores finais, neste capítulo, inicialmente serão caracterizados os elementos da amostra e seu comportamento em relação ao consumo de carne bovina por meio de uma análise descritiva. Os resultados da análise conjunta e da segmentação são discutidos em seguida e, por fim, as hipóteses do modelo proposto são testadas. Ao final do capítulo, são apresentados e discutidos os resultados das entrevistas com os agentes públicos e privados.

\subsection{Caracterização da amostra}

Consumidores das cinco regiões do município (centro, norte, sul, leste e oeste) fazem parte da amostra. As regiões mais representadas são a do centro, que compõe $26,2 \%$ da amostra devido à existência de grande número de açougues e a leste com 25,4\% devido ao grande número de supermercados.

Os 591 consumidores são, na sua maioria, constituídos de pessoas casadas $(68,4 \%)$, idosas $(40,4 \%)$, do sexo feminino $(69,7 \%)$ e que não trabalham $(53,5 \%)$. Essas proporções 
podem ser atribuídas ao fato de grande parte da amostra $(47,2 \%)$ ter sido abordada em seu domicílio. Ao todo, $50,1 \%$, declararam residir com quatro ou mais pessoas.

Na sua maioria, são pessoas de baixo poder aquisitivo, com renda de até mil reais $(47,5 \%)$, e com nível de instrução de médio a baixo (48,2\% possuem primário completo ou ginásio incompleto). Apesar disso, 76,5\% declararam residir em imóvel próprio e 61,3 \% possuem, pelo menos, um automóvel. Ao todo, 68,5\% declararam não possuir computador em sua residência. Os dados completos sobre as características da amostra são descritos no Anexo $\mathrm{J}$.

\subsection{Comportamento em relação ao consumo de carne}

Para maior confiabilidade ${ }^{50}$ das respostas, foram selecionados somente consumidores que regularmente compram e consomem carne bovina. Durante a realização do pré-teste foi constatada a dificuldade dos não-consumidores do produto opinarem sobre sua percepção em relação à qualidade do produto. A maioria da amostra $(65,8 \%)$ consome carne três ou mais vezes por semana.

Perguntados sobre qual item contribui para uma melhor percepção da alta qualidade da carne, em ordem decrescente: $73,6 \%$ responderam ser a presença de uma fiscalização intensiva; $56,0 \%$, o local de compra; $46,9 \%$, a existência de um certificado ou selo; $37,6 \%$, a educação e o conhecimento do consumidor; $29,4 \%$, a legislação rigorosa; $21,7 \%$, a marca do açougue ou supermercado; $15,7 \%$, a marca do produtor da carne e 15,2\%, a carne com embalagem. Somente $7 \%$ disseram ser o preço alto da carne o item que the proporciona a percepção da alta qualidade da carne.

Esses resultados demonstram a diferença de percepção existente em relação aos tipos de mecanismo formal: a fiscalização e a legislação. Sendo o primeiro mais importante, podemos supor que a definição de uma legislação rigorosa sem uma fiscalização eficiente pode ter um efeito reduzido na melhoria da percepção do consumidor. Em relação ao mecanismo informal, os itens que mais contribuem são o local de compra e o selo ou certificado. A confiança no estabelecimento parece ser suficiente para o consumidor, não

\footnotetext{
${ }^{50}$ Grau em que uma escala produz resultados consistentes quando se fazem medições repetidas das características (MALHOTRA, 2001, p. 263).
} 
havendo a necessitando de investimentos em marca. O selo ou certificado pode estar atrelado a uma maior credibilidade devido à auditoria de uma terceira parte. Em relação ao preço, os resultados sugerem que ações privadas de posicionamento devem vir associadas a outras variáveis que evidenciem a alta qualidade do produto. Um aumento de preços, isoladamente, pode ser associado a uma estratégia de aumento da margem de lucro e, não, de melhoria da qualidade do produto. Apesar de também contribuir pouco, a presença de embalagem no produto pode proporcionar maior percepção de qualidade se for associada a selos e certificados.

Em termos de conhecimento de aspectos relacionados à qualidade da carne, em ordem decrescente: $73,9 \%$ declararam conhecer o órgão Vigilância Sanitária; $67,2 \%$, as possíveis doenças causadas pela ingestão de carne contaminada; 58\%, o Serviço de Inspeção Federal (SIF) e $54,1 \%$, as substâncias utilizadas na produção da carne bovina. Campanhas educativas privadas ou públicas podem melhorar o conhecimento do consumidor e proporcionar uma maior confiança e preparo na avaliação da qualidade da carne. Isso é particularmente interessante para empresas que pretendem sinalizar ao consumidor seu diferencial de qualidade.

Questionados sobre os motivos que o levam a optar por um estabelecimento para a compra da carne, em ordem decrescente: $34,7 \%$, responderam que é a proximidade do local; $33,7 \%$, a qualidade da carne; $32,1 \%$, a confiança no estabelecimento; a mesma porcentagem declarou ser o preço, e somente $3,9 \%$, a intensidade da fiscalização. Isso evidencia que o mecanismo formal tem pouca associação com a escolha do local. A maior associação do preço com a escolha do local reforça a questão anterior.

A fidelidade ao estabelecimento pode ser considerada alta. A maioria diz comprar a carne em um único estabelecimento (52,6\%), sendo que $49,1 \%$ disseram que compram somente em supermercados. Os dados completos sobre o comportamento de compra são descritos no Anexo K.

\subsection{Resultados da análise conjunta}

Com base na ordenação realizada pelo consumidor dos produtos hipotéticos em termos da sua preferência por aqueles que lhe proporcionam uma maior percepção de segurança e 
qualidade, foram mensuradas as importâncias, para cada consumidor, dos atributos marca (mecanismo informal ou $\delta$ ), fiscalização (mecanismo formal ou F) e preço (margem ou 1-Z). Também foi possível mensurar a preferência pela intensidade (alta, média ou baixa) de cada um dos níveis dos atributos.

A importância ${ }^{51}$ dada ao atributo intensidade de fiscalização foi de $42,05 \%$; ao preço foi de $29,66 \%$ e à intensidade de conhecimento sobre a marca foi de 28,9\% (Figura 15). Isso significa que, em uma avaliação geral sobre toda a amostra, existe uma maior contribuição do mecanismo formal para a percepção de qualidade do produto. É importante ressaltar que produtos com maior intensidade deste atributo não têm uma maior probabilidade de serem preferidos no momento da compra porque a escolha pelo consumidor foi baseada na percepção de qualidade.
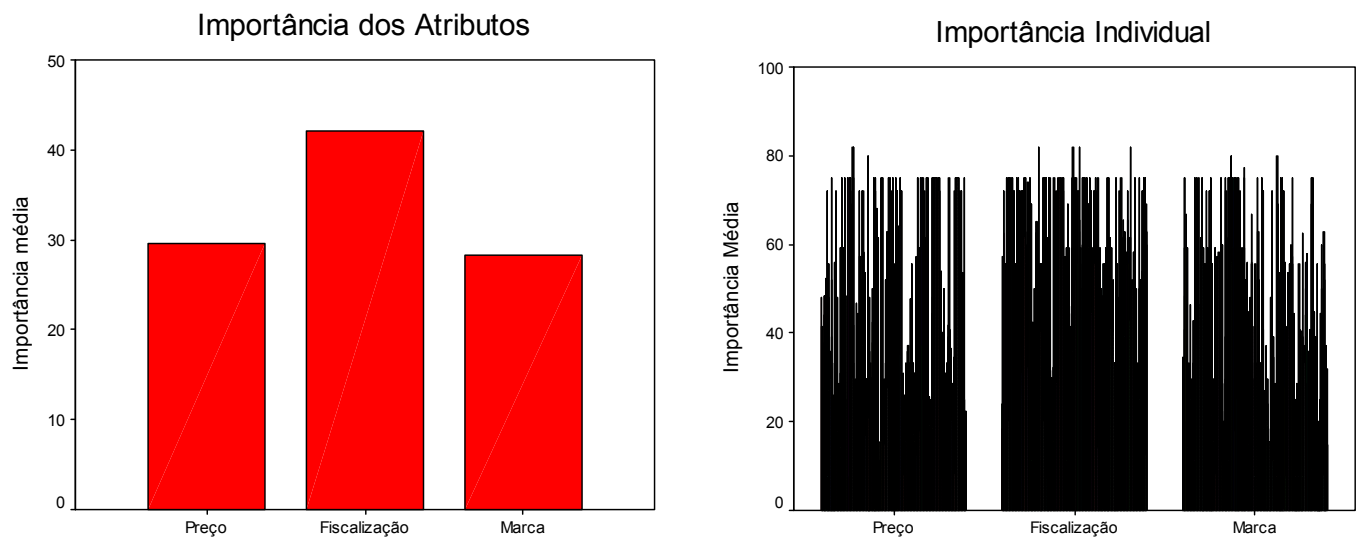

Figura 15. Importância geral em relação aos atributos, preço, marca e fiscalização

A preferência pelos níveis desses atributos foi crescente com o seu aumento conforme o esperado (Figuras 16 e 17), ou seja, em ordem crescente de preferência ficaram os níveis "sem marca", "marca desconhecida" e "marca conhecida" e para a fiscalização, a "ausência de fiscalização", "fiscalização eventual" e "fiscalização intensiva". Observando-se a preferência individual, nota-se que ela é mais homogênea sobre a fiscalização.

\footnotetext{
${ }^{51}$ O cálculo dos valores da importância dos atributos da amostra total, ou individual, para cada um dos consumidores pesquisados, é baseada na dispersão entre os níveis de cada atributo $\left(A_{i}\right)$ e pela participação $\left(P_{i}\right)$ desta dispersão perante os demais atributos: $A_{i}=A b s\left[M a x V_{i}-M_{i n} V_{i}\right]$. Onde: $A_{i}$ é igual a amplitude geral do atributo estudado $i ; \operatorname{MaxV}_{i}$ é o valor máximo entre os coeficientes dos níveis obtido para o atributo estudado $\mathrm{i}$ e $\mathrm{MinV}_{\mathrm{i}}$ é igual ao valor mínimo entre os coeficientes dos níveis do atributo estudado i. $P_{i}=100 \times A_{i} / \sum\left(A_{i} \ldots n\right)$; onde $P_{i}$ é igual a importância do atributo i para um consumidor específico ou para a amostra total; $\sum\left(\mathrm{A}_{\mathrm{i} . . . n}\right)$ é igual ao somatório das amplitudes de todos os atributos e $\mathrm{n}$ é igual ao número total de atributos.
} 

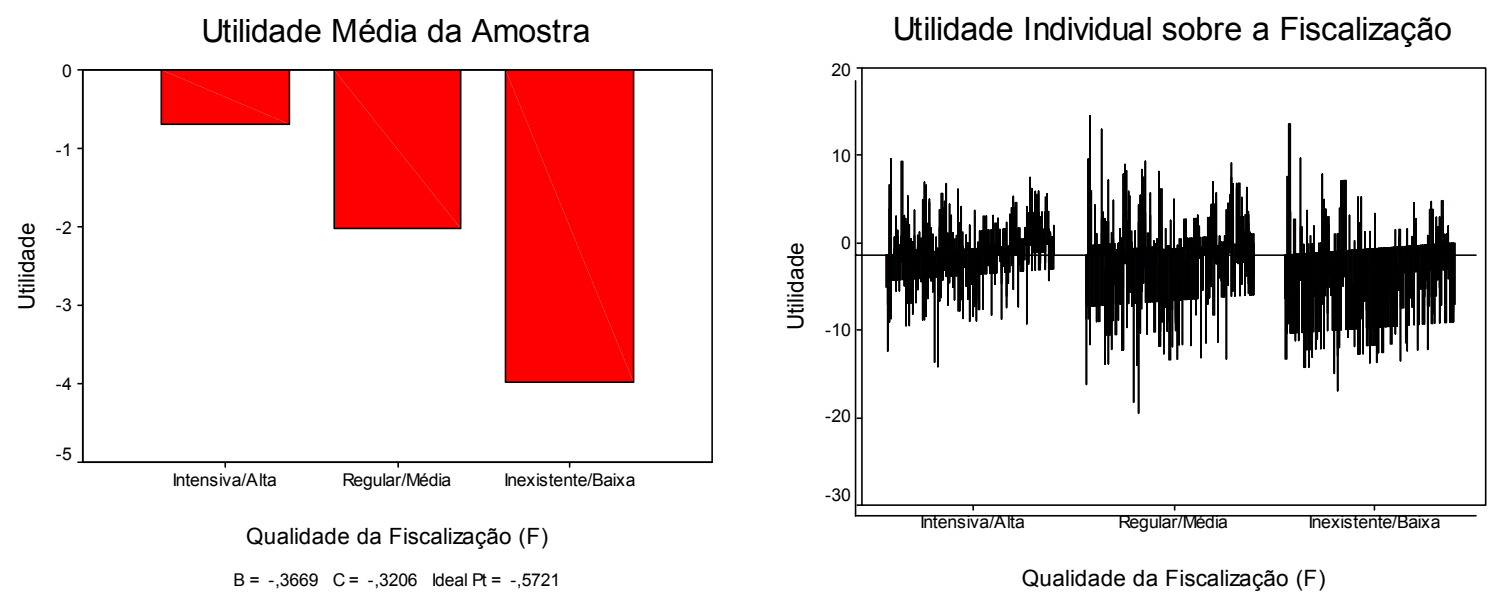

Figura 16. Preferência pelos níveis do atributo intensidade da fiscalização
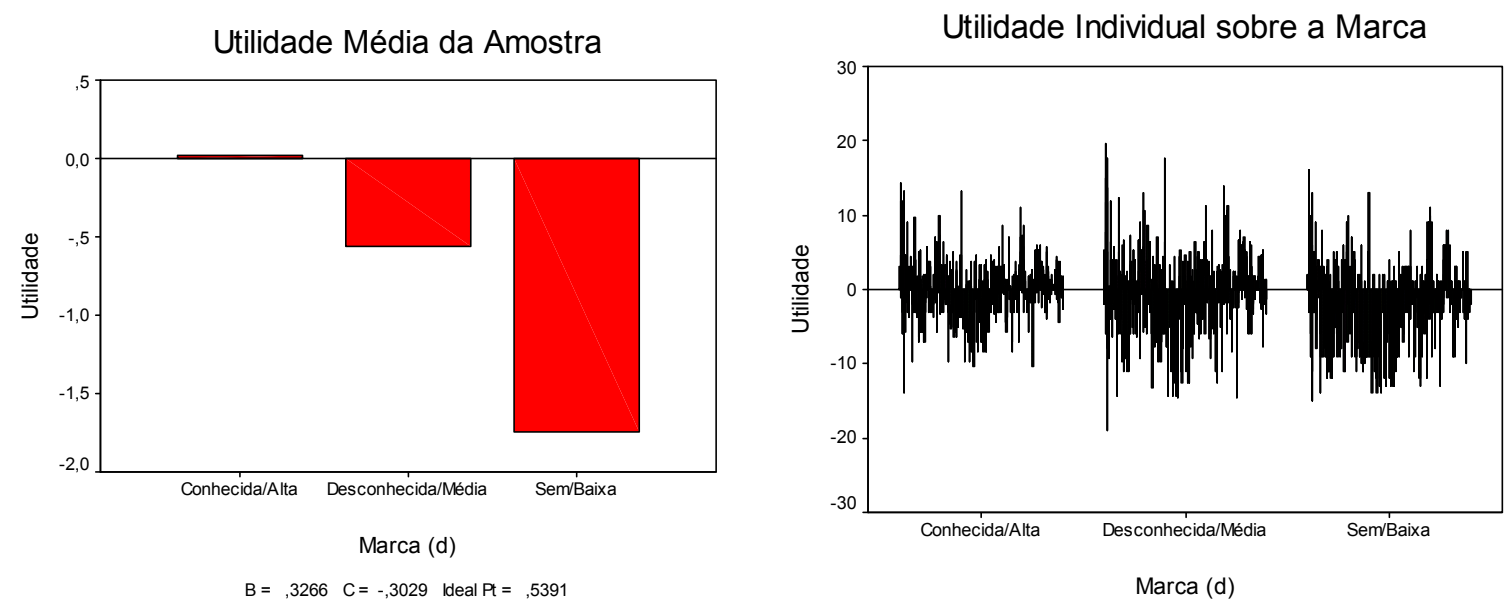

Figura 17. Preferência pelos níveis do atributo conhecimento sobre a marca

Em relação ao atributo preço (Figura 18), o nível médio foi o mais preferido ( $R \$ 12,00$ ), seguido pelo baixo $(R \$ 8,00)$ e alto $(R \$ 16,00)$. Isso pode significar um trade-off a favor de um preço mais baixo e médio, ou seja, o consumidor não associa o preço alto à alta qualidade do produto. É oportuno reforçar que apenas 7,1\% dos entrevistados afirmam que o preço contribui para uma maior percepção da alta qualidade do produto, enquanto $73,6 \%$ apontam a fiscalização intensiva. 

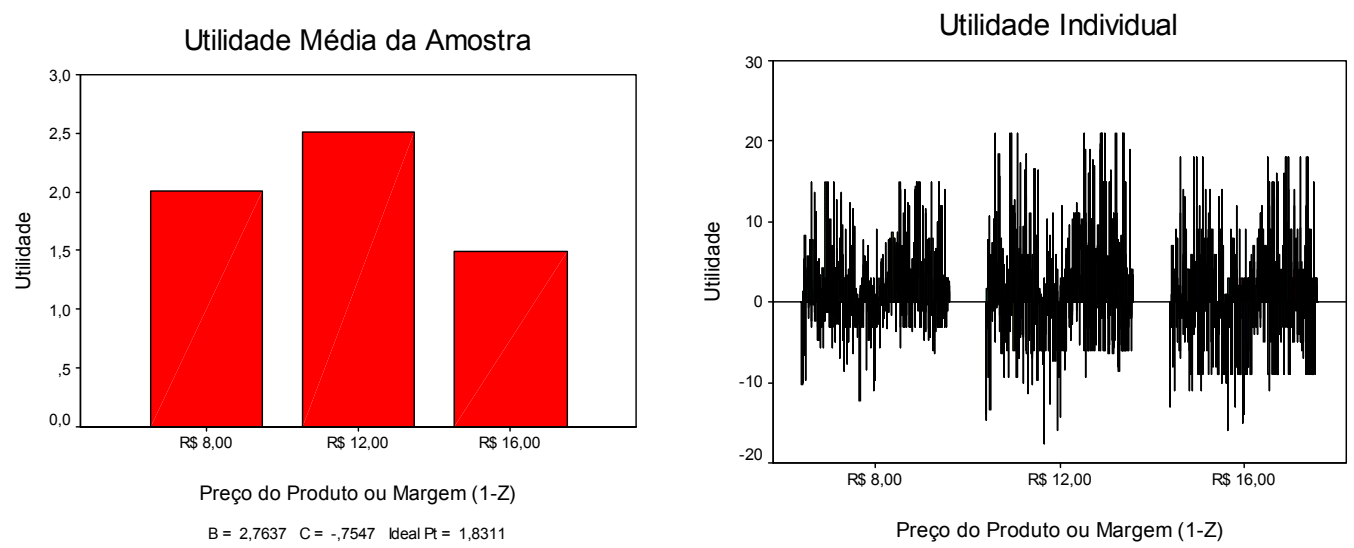

Figura 18. Preferência pelos níveis do atributo preço

Embora essa análise seja relevante, no sentido de mensurar a importância pelos atributos e a preferência por seus níveis, as hipóteses de substituição e complementaridade não podem ser testadas diretamente. Esta análise será abordada no item 6.5.

Uma das vantagens da análise conjunta é a de gerar uma estrutura de preferência para cada indivíduo. Com a estrutura de preferência de cada consumidor é possível associá-la a seus dados sócio-econômicos, caracterizando-o em função da sua renda, sexo, idade e grau de instrução, por exemplo, ou em relação ao seu comportamento quanto à sua percepção de risco e confiança na qualidade do mecanismo formal ou informal. Nesse caso, podemos identificar até que ponto a percepção dos consumidores são heterogêneas ou homogêneas em sua estrutura de preferência em relação à complementaridade ou substituição dos mecanismos formais e informais.

Tabela 5. Importância geral dos atributos em relação às características do respondente

\begin{tabular}{|c|c|c|c|c|c|}
\hline \multicolumn{2}{|c|}{ Característica } & \multirow{2}{*}{$\begin{array}{l}\text { Preço } \\
\frac{31,06}{}\end{array}$} & \multirow{2}{*}{$\begin{array}{l}\text { Marca } \\
26,32\end{array}$} & \multirow{2}{*}{$\begin{array}{c}\text { Fiscalização } \\
42,62\end{array}$} & \multirow{2}{*}{$\begin{array}{c}\begin{array}{c}\text { Quantidade } \\
\text { (em \%) }\end{array} \\
47,5\end{array}$} \\
\hline Renda & $\begin{array}{l}\text { Até } \mathrm{R} \$ \\
1.000,00\end{array}$ & & & & \\
\hline & $\begin{array}{l}\text { Acima de } R \$ \\
1.000,00\end{array}$ & 28,44 & 30,28 & 41,28 & 52,5 \\
\hline \multirow[t]{2}{*}{ Idade } & Até 50 anos & 28,64 & 30,64 & 40,73 & 59,4 \\
\hline & $\begin{array}{l}\text { Mais de } 50 \\
\text { anos }\end{array}$ & 31,23 & 25,12 & 43,65 & 40,6 \\
\hline \multirow[t]{2}{*}{ Sexo } & Feminino & 30,29 & 28,22 & 41,49 & 69,9 \\
\hline & Masculino & 28,30 & 28,81 & 42,90 & 30,1 \\
\hline \multirow[t]{2}{*}{ Grau de Instrução } & $\begin{array}{l}\text { Até ginásio } \\
\text { incompleto }\end{array}$ & 31,50 & 25,86 & 42,64 & 48,2 \\
\hline & $\begin{array}{l}\text { Ginásio } \\
\text { completo ou } \\
\text { superior }\end{array}$ & 28,00 & 30,76 & 41,24 & 51,8 \\
\hline
\end{tabular}


A Tabela 5 mostra que, para a amostra estudada, a importância dada aos atributos é bastante homogênea, principalmente em relação à fiscalização. Mesmo não sendo uma diferença expressiva, pessoas com maior renda, mais novas e com maior grau de instrução, atribuírem uma importância maior ao atributo conhecimento sobre a marca.

\subsection{Avaliação do modelo proposto}

Como, na técnica de análise conjunta, as interações não são avaliadas e com o uso do procedimento ortogonal reduziu-se o número de produtos, não existindo a combinação de produtos que permitam uma análise completa entre marca e fiscalização com preço constante e entre preço e fiscalização com marca constante, conforme proposto no modelo teórico, os dados foram reorganizados em uma matriz binomial de forma a permitir esta análise (Tabela 6).

Tabela 6. Modelo de tabulação para a análise de ordered probit e Poisson para o consumidor "001"

\begin{tabular}{|c|c|c|c|c|c|c|c|c|c|c|c|c|c|c|c|c|c|c|c|c|c|c|c|c|c|c|c|c|}
\hline Quest & Rank & $\mathrm{MmFm}$ & $\mathrm{MmFa}$ & $\mathrm{MmFb}$ & $\mathrm{MaFa}$ & $\mathrm{MbFb}$ & $\mathrm{MbFa}$ & $\mathrm{MaFm}$ & $\mathrm{MaFb}$ & $\mathrm{MbFm}$ & PmFm & $\mathrm{PaFa}$ & $\mathrm{PbFb}$ & $\mathrm{PbFa}$ & $\mathrm{PaFb}$ & PmFa & $\mathrm{PaFm}$ & $\mathrm{PmFb}$ & $\mathrm{PbFm}$ & $\mathrm{Pb}$ & $\mathrm{Pm}$ & $\mathrm{Pa}$ & $\mathrm{Fb}$ & $\mathrm{Fm}$ & $\mathrm{Fa}$ & $\mathrm{Mb}$ & $\mathrm{Mm}$ & $\mathrm{Ma}$ \\
\hline $\begin{array}{l}001 \\
001\end{array}$ & $\begin{array}{l}1 \\
2\end{array}$ & $\begin{array}{l}0 \\
0\end{array}$ & $\begin{array}{l}0 \\
0\end{array}$ & $\begin{array}{l}1 \\
0\end{array}$ & $\begin{array}{l}0 \\
1\end{array}$ & $\begin{array}{l}0 \\
0\end{array}$ & $\begin{array}{l}0 \\
0\end{array}$ & $\begin{array}{l}0 \\
0\end{array}$ & $\begin{array}{l}0 \\
0\end{array}$ & $\begin{array}{l}0 \\
0\end{array}$ & $\begin{array}{l}0 \\
0\end{array}$ & $\begin{array}{l}0 \\
0\end{array}$ & $\begin{array}{l}1 \\
0\end{array}$ & $\begin{array}{l}0 \\
1\end{array}$ & $\begin{array}{l}0 \\
0\end{array}$ & $\begin{array}{l}0 \\
0\end{array}$ & $\begin{array}{l}0 \\
0\end{array}$ & $\begin{array}{l}0 \\
0\end{array}$ & $\begin{array}{l}0 \\
0\end{array}$ & $\begin{array}{l}1 \\
1\end{array}$ & $\begin{array}{l}0 \\
0\end{array}$ & $\begin{array}{l}0 \\
0\end{array}$ & $\begin{array}{l}1 \\
0\end{array}$ & $\begin{array}{l}0 \\
0\end{array}$ & $\begin{array}{l}0 \\
1\end{array}$ & $\begin{array}{l}0 \\
0\end{array}$ & $\begin{array}{l}1 \\
0\end{array}$ & $\begin{array}{l}0 \\
1\end{array}$ \\
\hline 001 & 3 & 0 & 1 & 0 & 0 & 0 & 0 & 0 & 0 & 0 & 0 & 1 & 0 & 0 & 0 & 0 & 0 & 0 & 0 & 0 & 0 & 1 & 0 & 0 & 1 & 0 & 1 & 0 \\
\hline 001 & 4 & 0 & 0 & 0 & 0 & 0 & 0 & 1 & 0 & 0 & 0 & 0 & 0 & 0 & 0 & 0 & 1 & 0 & 0 & 0 & 0 & 1 & 0 & 1 & 0 & 0 & 0 & 1 \\
\hline 001 & 5 & 0 & 0 & 0 & 0 & 0 & 0 & 0 & 0 & 1 & 0 & 0 & 0 & 0 & 0 & 0 & 0 & 0 & 1 & 1 & 0 & 0 & 0 & 1 & 0 & 1 & 0 & 0 \\
\hline 001 & 6 & 0 & 0 & 0 & 0 & 0 & 0 & 0 & 1 & 0 & 0 & 0 & 0 & 0 & 0 & 0 & 0 & 1 & 0 & 0 & 1 & 0 & 1 & 0 & 0 & 0 & 0 & 1 \\
\hline 001 & 7 & 0 & 0 & 0 & 0 & 0 & 1 & 0 & 0 & 0 & 0 & 0 & 0 & 0 & 0 & 1 & 0 & 0 & 0 & 0 & 1 & 0 & 0 & 0 & 1 & 1 & 0 & 0 \\
\hline 001 & 8 & 1 & 0 & 0 & 0 & 0 & 0 & 0 & 0 & 0 & 1 & 0 & 0 & 0 & 0 & 0 & 0 & 0 & 0 & 0 & 1 & 0 & 0 & 1 & 0 & 0 & 1 & 0 \\
\hline 001 & 9 & 0 & 0 & 0 & 0 & 1 & 0 & 0 & 0 & 0 & 0 & 0 & 0 & 0 & 1 & 0 & 0 & 0 & 0 & 0 & 0 & 1 & 1 & 0 & 0 & 1 & 0 & 0 \\
\hline
\end{tabular}

Nessa matriz, as variáveis assumem valores em termos de probabilidade igual a um ou zero. Um determinado produto i receberá uma probabilidade um, caso seja escolhido em uma determinada ordem de preferência que varia de 1 a 9 e uma probabilidade zero nas demais. Como temos as nove combinações possíveis de produtos para todos os níveis, é possível verificar a interação entre todas elas. O pacote estatístico STATA (2003) foi utilizado para a análise de regressão de Poisson e o pacote estatístico SAS (2003) para a análise de regressão ordered probit (Anexo L).

\subsubsection{Complementaridade ou substituição entre marca e fiscalização.}

A Figura 19 mostra os resultados dos coeficientes das regressões de Poisson $\left(\beta_{i}\right)$ e Ordered Probit $\left(\beta_{i}{ }^{\circ}\right)$ em função dos três diferentes níveis dos atributos marca e fiscalização. Os resultados gerais da regressão são descritos no Anexo M.a. As variáveis de controle, preço 
e preço ao quadrado, e as variáveis que caracterizam o entrevistado como a idade, a renda familiar, o grau de instrução e o sexo não foram significativas.

Os resultados da análise do aumento da percepção da qualidade do produto pelo consumidor entre um nível baixo para médio de intensidade de marca ("sem marca" para "marca desconhecida") e fiscalização ("sem fiscalização" para "fiscalização esporádica"), demonstraram que esse incremento é significativamente maior quando há um aumento concomitante da intensidade da marca e da fiscalização em relação a um aumento isolado da marca $\left(\beta_{5}-\beta_{1}>\beta_{4}-\beta_{1}\right)$ e da fiscalização $\left(\beta_{5}-\beta_{1}>\beta_{2}-\beta_{1}\right)$. Nesse caso, a hipótese $H_{A}$ é confirmada, ou seja, marca e fiscalização são complementares para níveis baixos a médios dessas variáveis.

\begin{tabular}{|c|c|c|c|}
\hline$\delta$ alto & $\begin{array}{c}\text { MaFb }(\mathrm{Pa}) \\
\text { Produto } 8 \\
\beta_{7}=1,53 \\
\beta_{7}^{\prime}=-4,23\end{array}$ & $\begin{array}{c}\text { MaFm }(\mathrm{Pa}) \\
\text { Produto } 7 \\
\beta_{8}=1,73 \\
\beta_{8}^{\prime}=-3,43\end{array}$ & $\begin{array}{c}\text { MaFa }(\mathrm{Pb}) \\
\text { Produto } 4 \\
\beta_{9}=2,09 \\
\beta_{9^{\prime}}=-1,26\end{array}$ \\
\hline$\delta$ médio & $\begin{array}{c}\text { MmFb }(\mathrm{Pb}) \\
\text { Produto } 3 \\
\beta_{4}=1,15 \\
\beta_{4}{ }^{\prime}=-4,98\end{array}$ & $\begin{array}{c}\text { MmFm }(\mathrm{Pm}) \\
\text { Produto } 1 \\
\beta_{5}=1,86 \\
\beta_{5}^{\prime}=-3,15\end{array}$ & $\begin{array}{c}\text { MmFa (Pa) } \\
\text { Produto } 2 \\
\beta_{6}=1,88 \\
\beta_{6}{ }^{\prime}=-2,88\end{array}$ \\
\hline$\delta$ baixo & $\begin{array}{c}\text { MbFb (Pa) } \\
\text { Produto } 5 \\
\beta_{1}=-0,65 \\
\beta_{1}^{\prime}=-7,72\end{array}$ & $\begin{array}{c}\text { MbFm }(\mathrm{Pb}) \\
\text { Produto } 9 \\
\beta_{2}=1,42 \\
\beta_{2}^{\prime}=-4,27\end{array}$ & $\begin{array}{c}\text { MbFa }(\mathrm{Pm}) \\
\text { Produto } 6 \\
\beta_{3}=1,89 \\
\beta_{3}^{\prime}=-2,93\end{array}$ \\
\hline
\end{tabular}

$\beta_{i}$ são os coeficientes da regressão Poisson e $\beta_{i}$ ' são os coeficientes da regressão ordered probit Figura 19. Coeficientes da regressão entre marca e fiscalização

Os resultados da análise para o incremento dos níveis médios a altos das variáveis marca ("marca desconhecida" para "marca conhecida") e fiscalização ("fiscalização esporádica" para "fiscalização intensiva") também foram estatisticamente maiores quando o incremento é conjunto $\left(\beta_{9}-\beta_{5}>\beta_{8}-\beta_{5}\right.$ e $\left.\beta_{9}-\beta_{5}>\beta_{6}-\beta_{5}\right)$, ou seja, a hipótese $H_{B}$ é confirmada, marca e fiscalização são complementares para níveis médios a altos dessas variáveis.

A hipótese $\mathrm{H}_{\mathrm{C}}$ é confirmada já que o incremento na percepção de qualidade é menor no nível médio para alto do que no nível baixo para médio $\left(\beta_{5}-\beta_{1}>\beta_{9}-\beta_{5}\right)$, ou seja, o incremento da percepção de qualidade é menor a níveis mais altos de marca e fiscalização. Os resultados gerais dos testes são descritos no Anexo M.b. 


\subsubsection{Complementaridade ou substituição entre preço e fiscalização.}

A mesma análise foi realizada para a relação entre preço e fiscalização. A Figura 20 mostra os resultados dos coeficientes das regressões de Poisson $\left(\beta_{i}\right)$ e Ordered Probit $\left(\beta_{i}{ }^{i}\right)$ em função dos três diferentes níveis dos atributos preço e fiscalização. Os resultados gerais da regressão são descritos no Anexo N.a. As variáveis de controle marca e marca ao quadrado e as variáveis que caracterizam o entrevistado como a idade, a renda familiar, o grau de instrução e o sexo não foram significativas.

Os resultados da análise do aumento da percepção da qualidade do produto pelo consumidor entre um nível baixo para médio de intensidade de preço ("R $\$$ 8,00" para " $R \$$ 12,00") e fiscalização ("sem fiscalização" para "fiscalização esporádica"), demonstraram que esse incremento é significativamente maior quando há um aumento concomitante do preço e da fiscalização em relação a um aumento isolado do preço $\left(\beta_{5}-\beta_{1}>\beta_{4}-\beta_{1}\right)$ e da fiscalização $\left(\beta_{5}-\beta_{1}>\beta_{2}-\beta_{1}\right)$. Nesse caso, a hipótese $H_{D}$ é confirmada, ou seja, preço e fiscalização são complementares para níveis baixos a médios dessas variáveis.

\begin{tabular}{|c|c|c|c|}
\hline (1-Z) alto & $\begin{array}{c}\text { PaFb (Mb) } \\
\text { Produto } 5 \\
\beta_{7}=-0,69 \\
\beta_{7^{\prime}}=-7,26\end{array}$ & $\begin{array}{c}\text { PaFm (Ma) } \\
\text { Produto } 7 \\
\beta_{8}=0,89 \\
\beta_{8}^{\prime}=-3,61 \\
\end{array}$ & $\begin{array}{c}\text { PaFa }(\mathrm{Mm}) \\
\text { Produto } 2 \\
\beta_{9}=1,04 \\
\beta_{2}^{\prime}=-2,87 \\
\end{array}$ \\
\hline (1-Z) médio & $\begin{array}{c}\text { PmFb }(\mathrm{Ma}) \\
\text { Produto } 8 \\
\beta_{4}=0,64 \\
\beta_{4}{ }^{\prime}=-4,42\end{array}$ & $\begin{array}{c}\text { PmFm }(\mathrm{Mm}) \\
\text { Produto } 1 \\
\beta_{5}=0,98 \\
\beta_{5}^{\prime}=-3,17\end{array}$ & $\begin{array}{c}\text { PmFa }(\mathrm{Mb}) \\
\text { Produto } 6 \\
\beta_{6}=1,22 \\
\beta_{6}^{\prime}=-2,48\end{array}$ \\
\hline (1-Z) baixo & $\begin{array}{c}\text { PbFb }(\mathrm{Mm}) \\
\text { Produto } 3 \\
\beta_{1}=0,30 \\
\beta_{3}^{\prime}=-5,19\end{array}$ & $\begin{array}{c}\mathrm{PbFm}(\mathrm{Mb}) \\
\text { Produto } 9 \\
\beta_{2}=0,76 \\
\beta_{2}^{\prime}=-4,02\end{array}$ & $\begin{array}{c}\mathrm{PbFa}(\mathrm{Ma}) \\
\text { Produto } 4 \\
\beta_{3}=1,23 \\
\beta_{3}^{\prime}=-1,66\end{array}$ \\
\hline
\end{tabular}

$\beta_{i}$ são os coeficientes da regressão Poisson e $\beta_{i}$ ' são os coeficientes da regressão ordered probit

Figura 20. Coeficientes da regressão entre preço e fiscalização

O resultado da análise para o incremento do nível médio a alto da variável preço (" $R \$ 12,00$ " para "R\$ 16,00") e fiscalização ("fiscalização esporádica" para "fiscalização intensiva") não foi estatisticamente maior quando o incremento é conjunto $\left(\beta_{9}-\beta_{5}>\beta_{8}-\beta_{5}\right.$ e $\beta_{9}-\beta_{5}>\beta_{6}-$ $\beta_{5}$ ), ou seja, a hipótese $H_{E}$ é rejeitada, preço e fiscalização não são complementares para níveis médios a altos dessas variáveis. Na Figura 20 é possível observar que para todas as situações em que o nível de preço é alto ( $\mathrm{PaFb}, \mathrm{PaFm}$ e $\mathrm{PaFa})$, houve uma diminuição da percepção da alta qualidade do produto se comparado a valores médios. Esse mesmo resultado foi constatado na análise conjunta. 
A hipótese $H_{F}$ foi confirmada já que o incremento na percepção de qualidade é menor no nível médio para alto do que no nível baixo para médio $\left(\beta_{5}-\beta_{1}>\beta_{9}-\beta_{5}\right)$, ou seja, o incremento da percepção de qualidade é menor a níveis mais altos de preço e fiscalização. Os resultados gerais dos testes são descritos no Anexo N.b.

\subsection{Resultados da entrevista com os agentes privados}

Os estabelecimentos comerciais foram entrevistados no mesmo momento da realização da entrevista com os consumidores finais. Foram pesquisados quarenta e quatro estabelecimentos comerciais, entre os quais quinze supermercados e vinte e nove açougues. Trata-se de um estudo exploratório e descritivo e, portanto, hipóteses não foram testadas formalmente.

Perguntado ao estabelecimento de comercialização de carne bovina se o consumidor se preocupa com a qualidade da carne, 90,9\% responderam que sim. Essa porcentagem se reduz a $75 \%$ quando questionado se o consumidor pagaria mais por uma carne de melhor qualidade.

Em termos de estratégias privadas, quase metade dos estabelecimentos, 47,7\%, estaria disposta a investir em uma marca própria. É importante lembrar que relativamente poucos consumidores identificaram a marca do varejista como fator de melhoria na percepção da alta qualidade do produto. Já uma grande parcela dos estabelecimentos $(72,7 \%)$ estaria disposta a investir em propaganda que evidencie a qualidade da sua carne.

A percepção do agente privado em relação ao rigor da legislação nacional relacionada à garantia da qualidade da carne é na maioria alta (52,3\%). Já em relação ao grau de eficiência da fiscalização da vigilância sanitária, 45,5\% acreditam ser médio. Assim como demonstraram os resultados da análise com o consumidor, existe uma percepção de qualidade maior do mecanismo formal atribuída ao aspecto legal do que à fiscalização. As respostas às questões fechadas encontram-se no Anexo O. As questões abertas são discutidas a seguir e estão resumidas no Anexo $P$.

\section{Ações sugeridas para os estabelecimentos}


Como os atributos de qualidade da carne são de difícil percepção, foram sugeridas ações como a degustação do produto no próprio estabelecimento. Um estabelecimento afirma que é necessário "passar para o consumidor a idéia de que a carne tem qualidade, falando para eles sobre seus diversos aspectos e cuidados para que percebam que o açougue investe em qualidade". A utilização de uniformes, luvas e aventais também proporciona uma melhor percepção.

É possível, também, melhorar a percepção pela oferta conjunta de atributos tangíveis e pela educação. Mostrar, explicar como a carne é exposta. Praticar a higiene, retirar os excessos, carne limpa e bem exposta. Demonstrar e cortar a carne na frente do consumidor, melhorar a apresentação dos produtos e do estabelecimento. Toda carne deve vir com carimbo e marca do frigorífico. Investir em lojas de grande porte para atrair clientes. Explicar que a carne é de boa qualidade, que a empresa se preocupa em comprar carne fiscalizada. Conversas com os clientes para explicar a importância de se comprar carne com o selo do SIF.

Carne fresca. Adquirir carne a cada dois dias para que a aparência esteja boa. "O animal tem que ser macho, com partes traseiras grandes por ser mais macia". Quando a carne se torna escura, ela é retirada. Permanência da carne estocada também. A carne considerada de segunda fica exposta no balcão, enquanto que a de primeira fica no freezer. Todo o dia é cortada carne nova e, no dia seguinte, a que sobrou é moída. No supermercado, revisões diárias de todas as bandejas de carne, sendo avaliada a sua cor, aparência, odor e temperatura, sempre disponibilizando produtos dentro de sua vida útil.

Alguns ressaltam a importância do relacionamento com o cliente. Oferecer comodidade, variedade, respeito, agilidade, bom atendimento, refrigeração adequada, formação de funcionários, qualidade da carne e dos equipamentos, limpeza da loja, e a preocupação com os clientes e funcionários.

Com relação a estratégias de comunicação, é sugerida a conscientização do cliente quanto à necessidade de ele agir de forma pró-ativa na escolha e compra da carne. Um deles afirma que "o povo deveria ser mais educado e exigente quanto à qualidade da carne". A comunicação via indicação de clientes ("boca a boca") é vista como eficaz e de baixo custo. 
Foi salientada a importância dos procedimentos que devem ser adotados pelo próprio estabelecimento, como a utilização correta da câmara de congelamento, da câmara de resfriamento, funcionários uniformizados, uso de touca, luvas, capas, botas, calcas térmicas e avental. Carne com o selo do SIF, investimento em programas de treinamento em higiene e conscientização dos supermercados, açougues e consumidor.

Para o estabelecimento existe uma preocupação com a origem da carne. Uma melhor escolha no momento de comprar a carne do frigorífico pode significar melhores produtos. Isso pode sugerir ações por parte dos frigoríficos no sentido de melhorar sua padronização e garantir o fornecimento do produto com as garantias de qualidade exigidas no varejo. Custos de transação podem advir da necessidade de procura por parte do varejista da carne de qualidade. Comprar de frigoríficos idôneos.

Em relação ao mecanismo formal foi sugerida uma campanha de conscientização e uma fiscalização mais rigorosa. Mesmo com a dificuldade dos estabelecimentos que comercializam carne se diferenciarem em relação ao concorrente, poucos foram as ações sugeridas no sentido de adicionar valor via marca, atendimento e comunicação. A embalagem foi sugerida como melhoria da qualidade do produto. $\mathrm{O}$ cliente pode ter mais segurança comprando carnes preparadas nas bandejas e embaladas a vácuo.

\section{Ações sugeridas ao governo}

A grande maioria dos agentes de comercialização de carne bovina sugere, como melhoria da qualidade e segurança dos produtos, campanhas de conscientização e maior fiscalização por parte do governo, inclusive, segundo alguns, dos próprios fiscais. Essa fiscalização deveria ser mais eficiente e ocorrer em todos os estabelecimentos, principalmente nos frigoríficos. Alguns agentes ressaltam a necessidade de fiscalização sobre a refrigeração do estabelecimento, o armazenamento e o transporte adequado, a presença de embalagem com identificação de origem e a desossa prévia da carne. Também é sugerida a fiscalização de atitudes não-éticas do próprio varejista, como a de mudar o corte da carne para enganar o cliente, o que pode ser evitado com a identificação ou indicação da numeração correta de origem na carne. 
"Uma melhor fiscalização dos abatedouros e frigoríficos clandestinos e uma melhor vigilância sanitária, garantindo que os consumidores paguem um preço justo por uma carne saudável e de ótima qualidade", argumentou um funcionário de um supermercado responsável pela venda da carne no estabelecimento.

Campanhas em lugares como escolas e programas que visem à educação e à divulgação, tanto para os próprios estabelecimentos, como para os consumidores devido à sua falta conhecimento. Práticas que visem estimular atitudes como, por exemplo, a exigência do consumidor em solicitar notas fiscais e verificar a procedência ou origem do produto. "É preciso mostrar ao consumidor o que é qualidade. O cliente desconhece e, geralmente, procura apenas preço e isso não é sinônimo de qualidade" argumentou um proprietário de açougue. Campanhas publicitárias para conscientizar a população a comprar somente em estabelecimentos regularizados e com SIF. O papel da mídia e sua regulação também foram evidenciados. Uma notícia não verídica ou afirmações não comprovadas sobre o produto podem prejudicar a sua venda. Programas para educar e fazer com que a população conheça o procedimento correto para se vender a carne, desde o abatedouro até o supermercado. Poderia haver uma campanha educativa para que o consumidor aprenda a boicotar produtos de procedência ignorada.

Outros ainda colocam melhorias em aspectos não diretamente relacionados, como a melhoria das condições econômicas via diminuição dos juros. Também, incentivos financeiros governamentais, via financiamento, redução de impostos e diminuição do preço do produto para a implementação e melhoria das práticas de gestão da qualidade do produto.. Ênfase em uma maior credibilidade para a agroindústria nacional e investimento para o pequeno e médio produtor. A carne já deveria ser embalada, mas com um custo não muito alto.O governo poderia exigir que tais medidas fossem adotadas pelos fornecedores do produto.

Alguns não identificam nenhuma necessidade e outros ressaltam algumas melhorias já conquistadas, como a de obrigar os frigoríficos a desossar as carnes antes da venda, o que para alguns ainda não é realizado em todos os estabelecimentos.

Ações que proporcionam um benefício coletivo também são sugeridas ao estado, como divulgar internamente e no exterior a qualidade da carne brasileira. "Fazer campanhas de divulgação nos frigoríficos demonstrando a qualidade da carne brasileira, pois o produto 
brasileiro é o melhor do mundo". Fazer cumprir a lei, serem honestos, serem patriotas, vestirem a camisa do Brasil." Não tenho visto nenhum trabalho direcionada à venda de carne com selo de qualidade ou coisa parecida".

\subsection{Resultados da entrevista com o órgão regulador}

A pesquisa com o órgão público foi qualitativa, tendo como objetivo o entendimento do seu funcionamento e as dificuldades que enfrenta ao desenvolver suas atividades de garantia da qualidade e segurança do produto oferecido à população. Duas entidades foram escolhidas: a Vigilância Sanitária Municipal, que fiscaliza o comércio, com o intuito de caracterizar a estrutura e a situação local, e a Delegacia Federal do Estado de São Paulo, que tem atuação mais abrangente e inspeciona a indústria. Não se pretendeu, aqui, testar hipóteses. A fiscalização do frigorífico fica sob a responsabilidade da Secretaria de Defesa Agropecuária e a do varejo a cargo da Vigilância Sanitária.

\section{Vigilância Sanitária Municial}

A entrevista foi realizada com a supervisora da Vigilância Sanitária Municipal em fevereiro de 2003. A vigilância entrou em funcionamento no município de Piracicaba no final do ano de 1996, quando foram municipalizados os serviços de inspeção. A municipalização foi um grande avanço e, entre os benefícios, está a possibilidade de adequar a estrutura de fiscalização às especificidades de cada município como, por exemplo, o tipo de produção agroalimentar predominante na região.

Como os itens verificados na inspeção são diversos, abrangendo desde os processos, a estrutura física e os registros legais de funcionamento e, em alguns momentos, as normas são demasiadamente rigorosas para o tipo e estrutura do negócio, o bom senso acaba prevalecendo e alguns itens exigidos são flexibilizados e admitidos como válidos para o registro de funcionamento do estabelecimento, desde que não comprometam a segurança dos produtos. Os autos de infração variam de leve, grave a gravíssima. Existem casos de penalidades severas devido a reincidências e, até, interdições.

Sem o treinamento e o investimento necessários, muitos investem no segmento de refeições em decorrência do desemprego e dos baixos custos de entrada do negócio. Problemas 
específicos ocorrem quando restaurantes e lanchonetes são ampliados e criam seções sem a infra-estrutura necessária. Mesmo nos super e hipermercados ocorrem problemas: "não vemos o dia a dia do manipulador, se lavou as mãos, por exemplo".

A carne deve ter origem comprovada. Uma das soluções para o problema da clandestinidade seria a criação de um abatedouro municipal que incentivasse o abate dos animais em condições higiênicas adequadas. Mesmo com a devida identificação, a carne pode ser embalada em um invólucro já utilizado com uma outra etiqueta de origem.

A definição de normas claras e factíveis é apontada como um fator que dificulta a atuação do órgão. Diretrizes são criadas sem se verificar previamente a sua viabilidade prática de implementação e a infra-estrutura necessária. Um exemplo citado foi o de uma norma que estabeleceu a obrigatoriedade de treinamento para determinada fiscalização. Devido à falta de estrutura, foi necessário envolver outras entidades como o Serviço Nacional de Aprendizagem Profissional (SENAI). Essa norma acabou sendo abandonada.

Entre as dificuldades comentadas para o agente privado está a de se adequar aos requisitos legais. É comum o caso de empresas que pretendem regularizar sua atividade, mas, como o trâmite burocrático é complicado e demorado, acabam desistindo.

Melhorias são esperadas com a implantação do Sistema de Vigilância Sanitária, que permitirá a troca de informações entre as várias entidades, principalmente, com a esfera estadual. Um dos objetivos é transformar a unidade de Piracicaba em Serviço de Inspeção Municipal, que tem uma área específica para produtos de origem animal, com médico veterinário para aprovar a abertura e fiscalizar os estabelecimentos. No momento, caso seja necessário verificar uma ocorrência de abate clandestino, é preciso recorrer ao laudo de um veterinário de um município vizinho. A renovação da licença de funcionamento varia e, no caso do município, é anual.

\section{Delegacia Federal em São Paulo}

O objetivo da Delegacia Federal de Agricultura no Estado de São Paulo (DFA/SP), órgão vinculado ao Ministério da Agricultura e Abastecimento, é fiscalizar o abate e o processamento da carne nos frigoríficos e abatedouros. A entrevista ocorreu em dezembro de 2002 com o médico veterinário e Fiscal Federal Agropecuário. 
A estrutura da inspeção sanitária teve benefícios com o processo de descentralização. Por meio da Lei Federal no. 7.889 (BRASIL, 2002f), o serviço de inspeção passou a ser definido como de âmbito federal para os estabelecimentos que comercializam em nível interestadual e internacional, de âmbito estadual para os que comercializam em nível intermunicipal e de âmbito municipal para os que comercializam no próprio município. Esse processo atende às necessidades específicas do país, principalmente a dos estabelecimentos de nível médio, que não possuem recursos tecnológicos sofisticados, mas que atuam de forma condizente com os padrões de higiene exigidos.

A atuação da fiscalização tem se acentuado, principalmente, em função da maior demanda por qualidade e informação imposta pelos importadores ${ }^{52}$. O bom resultado do setor de carnes no mercado externo atesta a capacidade do sistema de fiscalização em fornecer produtos com qualidade.

No mercado interno, a ação governamental de normatizar e manter critérios atuais de orientação para a produção e comercialização de carne bovina tem como objetivo a promoção da saúde pública. Mesmo assim, é de consenso que a elevada clandestinidade existente exige ações que conduzam efetivamente à resolução desse problema.

Dada a impossibilidade de fiscalizar todos os estabelecimentos como forma de estabelecer um controle preventivo pleno, é delegado ao setor privado o desenvolvimento, a implantação e a execução das ferramentas de Análise de Perigo e Pontos Críticos de Controle (APPCC), Boas Práticas de Fabricação (BPF) e Procedimentos Padrão de Higiene Operacional (PPHO). Ao estabelecer normas que exigem a embalagem e a identificação do produtor (BRASIL, 2002g), o governo incentiva as ações privadas no sentido da criação de mecanismos informais como a marca.

\footnotetext{
${ }^{52}$ No caso da União Européia por suas Diretivas (UE, 2003 e anos anteriores)
} 


\section{VII - CONCLUSÕES}

A segurança do alimento é considerada um bem público e, portanto, sujeita à gestão pública que é, em geral, associada a uma menor eficiência gerencial e de maior custo. Além disso, pode sofrer interferências políticas em suas decisões. Por outro lado, a gestão privada sobre bens públicos é, em geral, complicada. A iniciativa privada pode não ter, em alguns casos, os incentivos adequados para desenvolver atividades econômicas ligadas a direitos de propriedade indefinidos e de baixo retorno, como fiscalizar a segurança do alimento, por exemplo. Entretanto, a participação privada é importante para se obter os avanços, os recursos necessários e reduzir os gastos e riscos governamentais. Em uma visão extrema, simplesmente entregar à iniciativa privada suas funções de normatizar e monitorar não parece ser o mais adequado. O acompanhamento e a parceria entre o privado e o público parecem ser essenciais. Este trabalho enfrentou o desafio de testar empiricamente essa complementaridade.

A segurança dos alimentos envolve diretamente vários agentes: o Estado, as organizações e o consumidor. A relação entre esses agentes é dinâmica. O aumento da exigência de qualidade por parte do consumidor força reações do Estado, no sentido de aumentar o seu rigor na formulação de normas e na atuação da fiscalização; e das organizações, na definição de instrumentos mais eficientes de diferenciação e adição de valor a seus produtos. Por outro lado, o Estado pode aumentar a sensibilidade do consumidor quanto à sua preocupação com aspectos de segurança em alimentos por meio de programas educativos. 


\subsection{Revisão geral dos capítulos anteriores.}

No capítulo um, a relação de complementaridade ou substituição entre as estratégias privadas e as políticas públicas é justificada como um importante tema de investigação, bem como um campo de contribuição teórica à administração e economia. O entendimento da dinâmica dessa interação perante a percepção de qualidade sobre um produto ou serviço pode contribuir para a utilização mais eficiente desses mecanismos. O escopo deste trabalho foi estudar o problema da segurança do alimento no segmento de carne bovina e a interação entre a intensidade de fiscalização, conhecimento sobre a marca e preço.

O capítulo dois define e retrata o vasto e crescente escopo do problema da segurança dos alimentos, mais especificamente da carne bovina, por se tratar de objeto deste estudo. Uma revisão do comportamento do consumidor em relação aos alimentos é realizada porque o modelo analisado se baseia na percepção da qualidade do produto. $\mathrm{O}$ ambiente institucional importa e possui uma relação de causa e efeito com os mecanismos. Os diferentes arranjos institucionais descritos neste estudo, presentes nos diversos países, sugerem a possibilidade de estudos de análise discreta comparada, podendo, inclusive, ser utilizado o modelo aqui proposto confrontando-se as diversas realidades em termos de rigor na fiscalização e nível de percepção do consumidor. Embora não avaliado neste estudo, impactos na coordenação vertical de uma cadeia agroalimentar podem ocorrer com mudanças nos mecanismos formais e informais conforme constatadas por algumas pesquisas.

As justificativas teóricas da necessidade de se utilizar os mecanismos são discutidas no capítulo três. O formal baseia-se, principalmente, nas falhas de mercado. O consumidor percebe uma maior qualidade do produto por que existe fiscalização por parte do Estado. Isso ocorre porque ele não consegue avaliar corretamente os atributos de qualidade pela insuficiente quantidade e qualidade de informações (assimetria de informação) que recebe e pela sua racionalidade limitada. Embora não avaliado neste estudo, pela ótica da escolha pública, o Estado pode incorrer em corrupção ao não punir, por exemplo, uma empresa na qual se detecta a baixa qualidade do produto. Por outro lado, a desconfiança por parte do consumidor em relação à eficiência da ação do Estado pode diminuir a eficiência do mecanismo formal. 
O informal está baseado, principalmente, na geração de confiança e na sinalização de qualidade proporcionada pela marca. O consumidor pode não confiar na empresa ao julgar que ela não tem incentivos para oferecer o nível desejado de segurança do produto. A marca pode melhorar a percepção de qualidade, e, por meio da lealdade, um maior número de transações ou recompra. Com isso, a empresa terá incentivo para investir em reputação porque espera receber retornos futuros. Ações coletivas, como a introdução de selos ou certificados, melhoram a percepção de valor e a confiança ao introduzir um terceiro agente fiscalizador que é o órgão de certificação. Uma revisão de literatura dos diferentes modelos e estratégias de comunicação permitiram caracterizar a sua contribuição para sinalizar a qualidade do produto.

O modelo teórico proposto foi desenvolvido no capítulo quatro e teve, como base, o modelo hedônico e o ferramental da teoria dos jogos. Mudanças podem ser realizadas em termos dos atributos definidos no modelo hedônico e na atuação dos agentes envolvidos no jogo. Essas mudanças podem gerar outras hipóteses a serem testadas.

Os métodos de amostragem, coleta e análise foram descritos no capítulo cinco. A técnica de análise conjunta permitiu definir produtos com diferentes intensidades dos atributos de mecanismo formal, informal e preço. O modelo de regressão de Poisson e Ordered Probit permitiu avaliar as mudanças entre os diferentes níveis desses atributos em função da percepção de qualidade do produto. A revisão de literatura sobre o modelo ordered probit mostrou que ele vem sendo utilizado em diversos estudos que se baseiam na análise conjunta.

Os resultados da pesquisa de campo foram apresentados e discutidos no capítulo seis. Em relação aos mecanismos informais, a análise descritiva mostrou que o uso de marcas nem sempre melhora a percepção do consumidor. Verificou-se que a eficiência da marca é maior em níveis de baixa fiscalização e preço. É importante ressaltar que a própria confiança no estabelecimento e o uso de selos ou certificados podem substituir a marca. A adoção de uma marca significa que os padrões de qualidade devem ser respeitados pela empresa, visto que o consumidor conseguirá, em transações futuras, identificar o produto e formar expectativas. Alguns produtos, devido à dificuldade para se manter a qualidade como, por exemplo, em situações climáticas adversas, terão pouco incentivo ao investimento em marca. 
Em relação aos mecanismos formais, a análise descritiva demonstrou que existe uma maior contribuição da fiscalização do que da normatização na percepção da alta qualidade do produto. A definição de uma legislação rigorosa deve ser acompanhada de uma sinalização de eficiência no seu cumprimento. A fiscalização contribui muito pouco para a escolha do estabelecimento se comparada à confiança nele depositada pelo consumidor. Nesse caso, podemos supor que o mecanismo informal substitui o formal.

A importância geral atribuída pelo consumidor à intensidade de fiscalização foi de 42,05\% seguida pelo preço $(29,66 \%)$ e pelo conhecimento da marca $(28,9 \%)$. A ordem crescente de preferências pelos níveis de fiscalização e marca foi: "baixo", "médio" e "alto". Já em relação à preferência pelos níveis do atributo preço, a ordem crescente foi: "alto", "baixo" e "médio". Isso pode significar um trade-off a favor de um preço menor e uma dissociação do atributo como elemento de percepção de alta qualidade. Não foi possível identificar segmentos de consumidores com comportamentos e preferências distintas na amostra estudada.

As principais conclusões sobre as hipóteses do estudo são discutidas no item a seguir.

\subsection{As principais conclusões}

Foram três as principais conclusões deste trabalho. A primeira é que, embora haja justificativas teóricas diferentes para a necessidade de sua adoção, é difícil separar as ações privadas das públicas e vice-versa. As respostas dos agentes públicos, privados e consumidores indicam uma clara convergência e sinergia positiva entre suas iniciativas conjuntas. Foi constatado empiricamente que os incrementos nos níveis de intensidade dos dois mecanismos simultaneamente elevam mais a percepção de qualidade do consumidor em relação ao produto do que um aumento exclusivo de qualquer um dos dois.

Nesse caso, o Estado pode elevar com mais eficiência a percepção de qualidade do consumidor definindo não só estruturas de fiscalização, mas normas que determinem ou incentivem a utilização da marca, por exemplo. A complementaridade pode significar para o Estado a economia de recursos com a participação privada em suas ações e vice-versa.

O incremento marginal decrescente na intensidade de complementaridade foi a segunda principal conclusão Os resultados deste estudo demonstram que a utilização dos 
mecanismos formais e informais, concomitantemente, eleva a percepção do consumidor nos dois níveis estudados (baixo para médio e médio para alto), mas essa complementaridade é menor em intensidades mais altas destes mecanismos. A dificuldade do consumidor em avaliar incrementos de qualidade no produto em níveis mais altos pode ser uma das explicações.

A ação conjunta entre Estado e empresa deve ser priorizada em situações em que é baixa a percepção da qualidade do produto. Estado e empresa podem elevar mais rapidamente a percepção de valor do consumidor se adotarem estratégias conjuntas como, por exemplo, em casos de escândalos com perda de credibilidade provocada por adulterações, fraudes e contaminações.

A terceira conclusão é a de que o atributo preço demonstrou ser pouco eficiente na percepção da alta qualidade do produto, principalmente em níveis altos. No nível alto de preço, a complementaridade não foi comprovada empiricamente e a percepção de qualidade diminuiu. A eficiência da estratégia de aumento de preço, juntamente com um aumento da fiscalização na percepção, só foi comprovada no nível baixo para médio. Apenas $7,1 \%$ dos entrevistados afirmam que o preço contribui para uma maior percepção da alta qualidade do produto, enquanto para a fiscalização intensiva a porcentagem foi de $73,6 \%$. Um alto preço pode ser associado pelo consumidor unicamente a incrementos na margem de lucro da empresa, não revertendo esse recurso adicional em gastos para melhorar a qualidade do produto.

Como houve a manutenção das mesmas características do produto em níveis diferentes de preço, não sendo incorporadas variações em outros atributos que permitem avaliar a adição de valor como diferentes tipos de corte, serviços adicionais como o de entrega e limpeza da carne, comprovação de origem, produção ecológica, investimentos em propaganda, entre outros, a complementaridade, mesmo em níveis altos, poderia ocorrer.

\subsection{Limitações do trabalho.}

É importante ressaltar as limitações quanto à extrapolação das conclusões em função do escopo regional e do número de consumidores entrevistados na pesquisa de campo. Devido à impossibilidade de testar a sua validade, podem ter ocorrido erros na definição das 
variáveis e dos respectivos níveis de intensidade: alto, médio e baixo, que mensuram os parâmetros (1-Z), F e $\delta$ do modelo.

O modelo assumiu que o consumidor tem renda suficiente para pagar pelos atributos de qualidade e tem condições de perceber as diferentes intensidades desses atributos. A utilização da escala ordinal não permite avaliar a diferença na intensidade de preferência entre os produtos.

\subsection{Campo para novas pesquisas.}

Novos estudos que aprofundem esta pesquisa são sugeridos, como a realização da coleta de dados em outros locais ou em outros períodos de tempo, bem como aplicações desse modelo a outros problemas que envolvam assimetria informacional e utilização de mecanismos formais e informais, como é o caso da preferência por atributos relacionados às características ambientais e sociais.

O modelo teórico pode incorporar outros agentes que podem participar ativamente no jogo. Um exemplo seria o consumidor. Ao perceber uma qualidade inferior, um consumidor $\mathrm{C}$ pode retaliar uma empresa $E$ a uma probabilidade $r$ e não retaliar a uma probabilidade (1-r). Essa retaliação poderia ocorrer na forma da não compra do produto i da empresa $\mathrm{E}$ devido à capacidade de identificação da origem da baixa qualidade nas transações futuras ${ }^{53}$.

Como o foco do estudo deu-se no segmento de comercialização de carne bovina, para verificar a utilização dos mecanismos no segmento de abate e processamento, também podem ser pesquisados os frigoríficos e abatedouros. Nesse caso, podem ser coletados dados que mostrem a percepção dos atributos de qualidade pelo varejista.

A escolha de outros produtos alimentares, ou, mesmo, de outros segmentos permitirá testar a validade do modelo. As evidências de complementaridade, neste estudo, sugerem a realização de outras pesquisas que aprofundem temas relacionados ao papel do estado, brand equity e comportamento do consumidor. 
Das hipóteses formuladas para este estudo, outras podem ser definidas e testadas empiricamente em outras situações de intensidade e de combinação entre o formal e informal.

O modelo pode responder a questões particulares como relações entre investimentos privados e públicos em tecnologia, ensino e segurança alimentar (food security), por exemplo. A complementaridade também pode ser avaliada entre os próprios agentes privados. Estratégias públicas de controle de zoonoses como a febre aftosa ou os investimentos em selos de qualidade exigem ações privadas conjuntas.

${ }^{53}$ Nesse caso, o fluxo futuro ficaria igual a $\prod_{t}^{\text {Baixa }}=p-z-s f+\delta\left[r(0)+(1-r) \prod_{t+1}^{\text {Baixa }}\right]$, sendo $\prod_{t}^{\text {Atta }}=\frac{p-z}{1-\delta}$ 。 fluxo futuro no caso de alta qualidade. Nesse caso haverá alta qualidade se $\prod_{t}^{\text {Baixa }} \leq \prod_{t}^{\text {Alta }}$ e podemos isolar $\mathrm{r}$ para analisar o equilíbrio do jogo. 


\section{REFERÊNCIAS BIBLIOGRÁFICAS}

ABIA. Associação Brasileira de Alimentos. Institucional. Disponível em: <http://www.abia.org.br/>. Acesso em: 8 jul. 2002.

ABIEC. Associação Brasileira das Indústrias Exportadoras de Carnes. Institucional. Disponível em: <http://www.abiec.com.br/index flash.html>. Acesso em 2 set. 2002.

ABLAN, E. Políticas de Calidad en el Sistema Agroalimentario Español. Agroalimentaria, $\mathrm{n}^{\circ}$ 10:63-72. 2000.

ABREU, Dilip. On the Theory of Infinitely Repeated Games with Discounting. v. 56, no. 2, Econometrica, p. 383-396, mar. 1988.

AKERLOF, George. The market for "lemons": quality uncertainty and the market mechanism, Quaterly Journal of Economics, Vol. 84, August 1970, pp 488-500.

ALBA, Joseph W.; HUTCHINSON, J. Wesley. Knowledge Calibration: What Consumers Know and What They Think They Know. Journal of Consumer Research, v. 27, p. 123156, sep. 2000.

ALCHIAN, Armen. The Basis of Some Recent Advances in the Theory of Management of the Firm. Journal of Industrial Ecnomics. № 14, p. 30-41, dez. 1965.

ALCHIAN, Armen. WOODWARD, Susan. Reflections on the Theory of the Firm. Journal of Institutional and Theoretical Economics. No 143, p. 36-110, mar. 1987.

ALSTON, Lee J.; EGGERTSSON, Thráinn, NORTH, Douglass C. Empirical Studies in Institutional Change. United Kingdom: Cambridge University Press. 1998, 361p.

ANTLE, John M. No Such Thing as a Free Safe Lunch: the Cost of Food Safety Regulation in the Meat Industry. American Journal of Agriculture Economics, Vol. 82, no. 2, 2000.

ARIELY, Dan. Controlling the Information Flow: Effects on Consumers' Decision Making and Preferences. Journal of Consumer Research, v. 27, p. 233-248, sep 2000.

ARNOLD, David. The Handbook of Brand Management. The Economist Books, International Management Series. Massachusetts: Perseus Books. 1992, 259p. 
AUST, Patrícia. An Institutional Analysis of Vertical Coordination verses Vertical Integration: The Case of the US Broiler Industry. Staff Paper no. 97-24, Michigan State University, june 1997, 13p.

AUSTRÁLIA. Food Science Austrália. Disponível em: <http://www.dfst.csiro.au/. Acesso em: 10 set. 2002.

BAIRD, Douglas G.; GERTNER, Robert H.; PICKER, Randal C. Game Theory and the Law. Harvard University Press. Cambridge, Massachusetts, London, England, 2000, 330p.

BAKER, A. B.; CROSBIE, P. J. Measuring food safety preferences: indentifying consumer segments. working paper. Santa Clara, Santa Clara University, 1993. 34p.

BANG, Hae-Kyong; ELLINGER, Alexander E.; HADJIMARCOU; John; TRAICHAL, Patrick A. Psycology \& Marketing. New York, Jun. 2000, p. 449-468.

BÁNKUTI, Ferenc Istvan. Entraves e Incentivos ao Abate Clandestino de Bovinos no Brasil. Dissertação (Mestrado em Engenharia de Produção) - Centro de Ciências Exatas e de Tecnologia, Universidade Federal de São Carlos, São Carlos, 2002, 229p.

BARCELLOS De, Marcia Dutra; CALLEGARO, Carlos Alberto Martins. A Importância da informação como indicador de qualidade: o caso da compra de carne bovina em Porto Alegre, Anais: Encontro Nacional de Pós-Graduação em Administração (ENANPAD), Salvador, 2002, 15p.

BARZEI, Yoram. Economic Analysis of Property Rights. Cabridge University Press. Second Edition. 1997, 161p.

BATRA, Raajev; OLLI T. Ahtola. Measuring the hedonic and Utilitarian Sources of Consumer Atitudes, Marketing Letters, 2 April, 1991, p. 159-70

BERGKAMP, Lucas. Biotech Food and the Precautionary Principle under EU and WTO Law. Social Science Electronic Publishing, Inc. (SSEP), 2001, 38p.

BERGSTROM, Theodore C.; MILLER, John H. Experiments With Economic Principles. McGraw Hill. September 1996.;

BESANKO, David; DRANOVE, David; SHANLEY, Mark. Economics of Strategy. $2^{\mathrm{a}}$. ed., John Wiley \& Sons, 2000, 644p.

BIMA. Qualités des produits agro-alimentaires: à chaque stratégie son ou til. Dossier BIMA, 1994, p.18-27.

BRASIL. Constituição. Constituição da República Federativa do Brasil, Brasília: Senado Federal, Centro Gráfico, 1988, 292p.

BRASIL. Ministério da Agricultura e Reforma Agrária. Departamento de Inspeção de Produtos de Origem Animal (DIPOA). Institucional. Disponível em: <http://www.agricultura.gov.br/sda/dipoa/index.htm>. Acesso em: 10 set. 2002c.

BRASIL. Ministério da Agricultura, Pecuária e Abastecimento. Institucional. Disponível em $<$ http://www.agricultura.gov.br>. Acesso em 10 set. 2002a.

BRASIL, Instituto Nacional de Metrologia (INMETRO). Institucional. Disponível em: <http://www.inmetro.gov.br/>. Acesso em: 07 jul. 2002e.

BRASIL. Ministério da Agricultura, Pecuária e Abastecimento. Lei $n^{\circ} .7 .889$, de 23 de novembro de 1989. Dispões sobre a inspeção sanitária e industrial dos produtos de origem, 
e dá outras providências. Diário Oficial da União, Brasília, 24 de novembro de 1989. Disponível em <http://www.agricultura.gov.br>. Acesso em 10 set. $2002 f$.

BRASIL. Ministério da Agricultura, Pecuária e Abastecimento. Portaria $n^{\circ}$. 46 de 10 de fevereiro de 1998. Institui o sistema de Análise de Perigos e Pontos de Críticos de Control APPCC. Diário Oficial da União. Disponível em: <http://www.agricultura.gov.br>. Acesso em 10 set. 2002g.

BRASIL. Ministério da Agricultura, Pecuária e Abastecimento. Secretaria de Defesa Agropecuária. Departamento de Defesa Animal (SDA/DDA). Institucional. Disponível em: <http://www.agricultura.gov.br/sda/dda/index.htm>. Acesso em: 10 set. 2002b.

BRASIL. Ministério da Saúde. Agência Nacional de Vigilância Sanitária (ANVISA). Institucional. Disponível em: < http://www.anvisa.gov.br/> Acesso em: 10 set. 2002d.

BRASIL. Ministério da Saúde. Diretrizes Básicas Para Análise de Alegação de Propriedades em Rotulagem de Alimentos. Agência Nacional de Vigilância Sanitária (ANVISA). Institucional. Disponível em: < http://www.anvisa.gov.br/> Acesso em: $20 \mathrm{dez}$. 2001.

BUCHANAN, James M. Politics as Public Choice: The Collective Works of James M. Buchanan. Liberty Fund, Indianapolis, IN, 2000, 497p.

BURGUET, Roberto. Optimal Repeated Purchases when Sellers are Learning About... Journal of Economic Theory, v.. 68, no. 2, p. 440-415, Feb. 1996.

BUZBY, Jean C.; FOX, John A.; READY, Richard C.; Crutchfield, Stephen. Measuring Consumer Benefits of food Safety Risk Regulation. Journal of Agriculture and Applied Economics, Vol. 30, no. 1, July, 1998.

BUZBY, Jean C.; READY, Richard C. Do Consumers Trust Food Safety Information? Food Review. Jan-Apr, 1996. p. 46-49.

CANTARELLI F. El Observatorio Internacional para la valorización de los alimentos tradicionales de.los países mediterráneos de la Unión Europea, Agroalimentaria, Junio, $\mathrm{N}^{\circ}$ 10: 45-51. 2000.

CASWELL, Julie A. Valuing the benefits and costs of improved food safety and nutrition. The Australian Journal of Agricultural and Resource Economics, vol 42, no. 4, p. 409-424, 1998.

CASWELL; Julie. A. et al. Economics of Food Safety. New York: Elsevier Science Publishing, 1991, 356p.

CEAGESP. Companhia de Entrepostos e Armazéns Gerais de São Paulo. Institucional. Disponível em: <http://www.ceagesp.com.br/>. Acesso em 15 jan. 2003.

CHAUDHURI, Arjun; HOLBROOK, Morris B. The Chain of Effects from Brand Trust and Brand Affect to Brand Performance: The Role of Brand Loyalty. Journal of Marketing, , $v$. 65, no. 2, p. 81-93, Apr. 2001.

$\mathrm{CHOI}, \mathrm{E}$. Kwan; JENSEN, Helen H. Modeling the Effect of Risk on Food Demand and the Implications for Regulation. In: CASWELL, Julie A. Economics of Food Safety, Elsevier, Science Publishing Co., Inc. 1991, p. 29-44.

COASE, R. H. The problem of social cost. The Journal of Law Economics. Vol. III, out., p.01-44, 1960. 
COHEN, Mark A. Monitoring and Enforcement of Environmental Policy. Trabalho de Pesquisa. Vanderbilt University. Nashville, TN. August 1998, 59p.

CONFERÊNCIA VIRTUAL. Primeira Conferência Virtual Global sobre Produção Orgânica de Bovinos de Corte. Disponível em:

<http://www.conferencia.uncnet.br/pantanal/index.php?lin=pt.> Acesso em: 3 out. 2002.

COSTA, Ediná Alves. Vigilância Sanitária: Proteção e Defesa da Saúde. Editora Hucitec, Sociedade Brasileira de Vigilância de Medicamentos, São Paulo, 1999, 460p.

CREED, W. E. Douglas; MILES, Raymond E. Trust in Organizations: a Conceptual Framework Linking Organizational Forms, Managerial Philosophies, and the Opportunity Costs of Controls, cap 3, p. 16-38, In: KRAMER, Roderick M.; TYLER, Tom R. Trust in Organizations: Frontiers of Theory and Research. London: Sage Publications. 1996, 429p. CUÉLLAR, Leila. As Agências Reguladoras e seu Poder Normativo. Dialética, São Paulo, 2001, 159p.

DAVIS, J. H.; GOLDBERG, R. A. A concept of agribusiness. Harvard University, 1957. $136 \mathrm{p}$.

DEMSETZ, H. Toward a theory of property rights. American Economic Association, p.34759, may 1967.

DENNIS, F. Donald. An ordered probit analysis of public values for use in multiple objective decision-makign. Computers and Eletronics in Agriculture, no. 27, p. 127-137, 2000.

DIXIT, Avinash K.; NALEBUFF, Barry J. Thinking Strategically: The Competitive Edge in Business, Politics, and Everyday Live. New York: . W. Norton \& Company. 1991, 393p.

DOUGLAS, E. J.; CALLAN, S. Managerial Economics: Analysis and Strategy, PrenticeHall, 1992. 655p.

EDUARDO, Maria Bernadete de Paula. Vigilância Sanitária. Saúde \& Cidadania. Para gestores municipais de serviços de saúde. Editora Fundação Peirópolis, Ltda. 1998, 460p.

ELIAS, Attoney Stephen. Trademark: Legal Care for Your Business \& Product Name. 5a. ed., Nolo. 2000, 14/8 p.

ENRIQUEZ-CABOT; GOLDBERG, Ray. Technology crises and the future of

agribusiness: BSE in Europe. Case study. Harvard: Harvard Business School, 1996. 41p.

EUA. Food and Drug Administration (FDA). Institucional. Disponível em:

<http://www.fda.gov/.> Acesso em 5 set. 2002a.

EUA. Food and Drug Administration. Center for Food Safety and Applied Nutrition (CFSAN). Hazard Analysis Control Critical Point. Disponível em:

<http://www.cfsan.fda.gov/ comm/haccpov.html>. Acesso em: 7 set. 2002b.

EUA. Food and Drug Administration. Center for Food Safety and Applied Nutrition (CFSAN). Institucional. Disponível em: <http://www.cfsan.fda.gov>. Acesso em: 7 set. 2002c.

EUA. World Monitor Research. Disponível em: < http://www.worldmonitor.org >. Acesso em: 5 jul. 2002.

FAO. Food Aid Organization. Red de Cooperación Técnica sobre Sistemas de Vigilancia Alimentaria y Nutricional (Red SISVAN). Disponível em: http://www.rlc.fao.org/redes/sisvan e http://www.usach.cl/sisvan/. 
FLANDRIN, Jean-Louis; MONTANARI, Massimo. História da Alimentação. Ed. Estação Liberdade. São Paulo. 1996, 885p.

FMI. Food Marketing Institut. World Economic Research. Disponível em: <http://www.fmi.org> . Acesso em: 11 out. 2002.

FOXALL, Gordon R. The marketing firm. Journal of Economics Psycology, no. 20, abr. 1999, p. 207-234.

FOZ, Ira. A Pecuária do Brasil Prepara-se para Conquistar Mercados. Pecuária de Corte. São Paulo, ano 13, no. 115, p. 20-24, nov/dez. 2001.

FRANÇA. Ministère de l'agriculture de l'alimentation de la pêche et des affaires rurales. Disponível em: <http://www.agriculture.gouv.fr/> . Acesso em: 10 out. 2003.

FRAZÃO, E. The American Diet. Health and Economic Consequences: An Economic Research Service Report. United States Department of Agriculture. Agriculture Information Buletin, Washington: n. 711, 1995. 25p.

FREWER, Lynn; SCHOLDERER, Joachim; DOWNS, Clive; BREDAHL, Lone.

Communicating About the Risks and Benefits of Genetically Modified Foods: Effects of Different Information Strategies. MAPP Working paper no. 71. July 2000, 48p.

FRIEDMAN, Daniel; SUNDER, Shyam. Experimental Methods - A primer for Economist. Cambridge University Press, Cambridge, 1994.

FUDENBERG Drew; TIROLE, Jean. Game Theory. Cambridge, Massachusetts. 2002, $579 p$.

GATTEGNO, I. HACCP: Le futur de la sécurité alimentaire. RIA, n. 524, 1994, p.124-27.

GIADON, P. et al. Quality assurance of agricultural products and human health: pesticides residues in grapes, wines and vegetables. In: Fourth Minessota/Padova Conference on Food, Agriculture and the Enviroment, Minessota , 1994. 8p . Proceedings.

GIBBONS, Robert. Game Theory for Applied Economists. New Jersey: Princeton University Press. 1992, 267p.

GINTIS, Herbert. Beyond Homo Economicus: evidence form experimental economics. Ecological Economics, v. 35, p. 311-322, 2000.

GREEN, P. E.; SRINIVASAN, V. Conjoint analysis in consumer research: issues and outlook. Journal of Consumer Research, v. 5, n 2, p.103-123, 1978.

GREENE, William H. Econometric Analysis. Prentice Hall, 5a. ed., 2003, 1026p.

GRUNERT, K. G.; LARSEN, H. H.; MADSEN, T. K.; BAADSGAARD, A. Market orientation in food and agriculture. Massachussetts: Kluwer Academic Publishers, 1996.

GRUNERT, Klaus G. Current Issues in the Understanding of Consumer Food Choice. The MAPP Centre, The Aarhus School of Business, Denmark, 2002, 21p.

GRUNERT, Klaus G. Current issues in the undestanding of consumer food choice. MAPP, 2001, p 3.

GRUNERT, Klaus G; LÄHTEENMÄKI, Liisa; NIELSEN, Niels Asger; POULSEN, Jacob B.; UELAND, Oydis; ASTRÖM, Annika. Consumer Perception of Food Products Involving Genetic Modification: Results from a Qualitative Study in four Nordic Countries. Working paper $n$ 72, The MAPP Centre, jul. 2000. 
GUNNTHORSDOTTIR, Anna; MCCABE, Kevin; SMITH, Vernon. Using the Machiavellianism instrument to predict trustworthiness in a bargaining game. Journal of Economic Psychology, v. 23, p. 49-67, fev. 2002.

GUTMAN, J. A means-end chain model based on consumer categorization processes. Journal of Marketing. 46(2), 1982. Pag. 60-72.

HAEFELE, Michelle A.; LOOMIS, John B. Improving Statistical Efficiency and Testing Robustness of Conjoint Marginal Valuations. American Journal of Agricultural Economics. Vol. 83, no. 5, nov. 2001, p. 1321-1327.

HAIR Jr., Joseph F.; ANDERSON, Rolph E.; TATHAM, Ronald L.; BLACK, William C. Multivariate Data Analysis. New Jersey: Prentice Hall, 5a. ed., 1998, 730p.

HALBRENDT, C. et al. Public Perceptions of Food Safety in Animal Products. Journal of Agribusiness. p. 85-96, 1991.

HENSON S.; TRAILL, B. The Demand for Food Safety. Market Imperfections and the Role of Government. Food Policy, p.152-162, 1993.

HOBBS, J. E.; KERR W. A. Cost of monitoring food safety and vertical coordination in agribusiness: what can be learned from the Britich Food Safety Act 1990? Agribusiness an International Journal, v. 8, n. 6, p.575-584, 1992.

HOGAN Jr., Harold F. The Safe Food Act: A Consumer Group's Perspective. Case Study. Harvard Business School. 1999, 20p

HORSTMANN, Ignatius J.; MacDONALD, Glenn M. When Is Advertising a Signal of Product Quality? Journal of Economics \& Management Strategy. v. 3, n. 3, p. 561-584, Fall, 1994.

HORSTMANN, Ignatius J.; MacDONALD, Glenn M. Is Advertising a Signal of Product Quality? Evidence from the compact disc player market, 1983-1992. International Journal of Industrial Organization. v. 21, n. 3, p. 317-345, march, 2003.

HUNTER, Beatrice T. Should the U.S. Have a Single Food Agency? Consumer Research. p. 21-23., nov. 2001.

IBGE Instituto Brasileiro de Geografia e Estatística. Disponível em: $<$ http://www.ibge.gov.br/home/default.php>. Acesso em 2 set. 2002.

IBOC. Instituto de Orientação ao Consumidor. Institucional. Disponível em: $<$ http://www.iboc.org.br/>. Acesso em: mar. 2003.

IDEC. Instituto de Defesa do Consumidor. Institucional. Disponível em: $<$ http://server.digipronto.com.br/idec.org.br/paginas/inicial 2.asp>. Acesso em: 8 jul. 2002.

INSTITUTO BIOLÓGICO DE SÃO PAULO. Institucional. Disponível em: <http://www.biologico.sp.gov.br/>. Acesso em: 15 out. 2002.

ISO. International Organization of Standartization. Institucional. Disponível em: <http://www.iso.org/>. Acesso em: 10 out. 2002.

JAPÃO. National Institute of Infectious Diseases (NIID). Disponível em: <http://www.nih.go.jp/niid/index-e.html.> Acesso em: 10 set. 2002.

JENSEN, Helen H.; UNNEVERHR, Laurian J.; GOMEZ, Miguel Ignacio. Costs of Improving Food Safety in the Meat Sector. Journal of Agricultural and Applied Economics, Vol. 30, no. 1, July, 1998. 
JONAS, M. S.; BECKMANN, S. C. Functional Foods: Consumer Perceptions in Denmark and England. MAPP. Working Paper, October, 1998, 34p.

JURAN, J. M. A Qualidade desde o Projeto. 2. ed., São Paulo: Pioneira, 1992. 551p.

KAGEL, John H.; ALVIN, E. Roth. The Handbook of Experimental Economics. Princeton University Press. 1995.

KAHN, Alfred E. The Economics of Regulation: Principles and Institutions. Massachusetts Institute of Technology. Volume I, 1998. 199p.

KAHNEMAN, Daniel; AMOS, Tversky (editores). Choices, Values and Frames. Cambridge University Press - Russell Sage Foundation. 2000.

KAO, Edward P. C.; SMITH, Marison Spokoni. Discounted and Per Unit Net Revenues and Costs of Product Warranty: The Phase-type Lifetimes. Management Science, v. 39, no. 10, p. 1246-1254 oct. 1993.

KATZ, Avery Wiener. Foundations of The Economic Approach to Law. Information. Foundation Press, New York. 1998, 330p.

KLEIN, Benjamin; LEFFLER, Keith B. The Role of Market Forces in Assuring Contractual Performance. Journal of Political Economy, v. 89, no. 4, p. 615-641, 1981.

KOTLER, Philip. Marketing Management. Prentice Hall: New Jersey, 11 ed., 2003, 706p.

KRAUSS, Michael. Product Liability and Game Theory: One More Trip to the Choice-of-Law Well. George Mason University School of Law. Law and Economics Working Paper Series. http://ssrn.com/abstract id=307143. Acesso em 8/08/2002.

KREPS, David M. A Course in Microeconomic Theory. New Jersey: Princeton University Press, 1990, 839p.

KREPS, David M. Game Theory and Economic Modelling. Oxford: Clarendon Press. 2001, 195p.

KUHN, Harold W. Classics in Game Theory. New Jersey: Princeton University Press. 1997, $362 p$.

LAFFONT, Jean-Jacques; TIROLE, Jean. A Theory of Incentives in Procurement and Regulation. The MIT Press Cambridge, Massachusetts, London, England, 1993, 705p.

LANCASTER, K. Consumer Demand: A new approach. New York: Columbia University Press, 1971.

LAW, Marc, T. The Transaction Cost Origins of Food and Drug Regulation. ISNIE, 2001.

LAZZARINI, Sergio G.; MILLER, Gary J; ZENGER, Todd R. Order with some Law:

Complementarity vs. Substituion of Formal and Informal Arrangements. São Paulo: IBMEC working paper. 52p., 2002.

LEWINSOHN-ZAMIR, Daphna. Consumer Preferences, Citizen Preferences, and the Provision of Public Goods. The Yale Law Journal, v. 108, p. 377-406, 1998.

LURIE, Nicholas Hubbard. The Role of Information Structure in Decision Making. Tese (PhD., Business Administration) University of California, Berkeley. Spring, 1999, 145p.

MADDALA, G. S. Limited-dependent and qualitative variables in econometrics. Cambridge University Press, New York, 1990, 401p. 
MALHOTRA, Naresh K. Pesquisa de marketing: uma orientação aplicada. $3^{a}$. Ed., Bookman: Porto Alegre, 719p.

MERCURO, Nicholas; MEDEMA, Steven G. Economics and the Law: From Posner to PostModernism. Chapter 3: Public Choice Theory. Princeton University Press, Princeton, New Jersey. 1997, 235p.

MILLER, G. A. The magical number seven, plus or minus two: some limits on own capacity for processing information. Psicological Review, n 63, p.81-97. 1956.

MILNE, George R.; BOZA, Maria-Eugênia. Trust and Concerns in Consumers` Perceptions of Marketing Information Management Practices. Journal of Interactive Marketing. New York, Winter 1999, p. 05-24.

MOJDUSZKA, Eliza M.; CASWELL, Julie A. A test of nutricional quality signaling in food markets prior to implementation of mandatory labeling. American Journal of Agricultural Economics. v. 82, p. 298-309, maio de 2000.

MOORMAN, Christine; MATULICH, Erica. A Model of Consumers' Preventive Health Behaviors: The Role of Health Motivation and Health Ability. Journal of Consumer Research. v. 20, p. 208-228, Sep. 1993.

MOREL, F. Dossier laboratoire et qualité. Le moteur de la certidication. Process. no. 1088, nov. 1993, p.31-33.

MORGAN, Robert M; HUNT, Shelby D. The Commitment-Trust Theory of Relationship Marketing. Journal of Marketing. V. 58, p. 20-38, jul. 1994.

MULDER J. Informe sobre una política de calidad para los productos agrarios y agroalimentarios. 1998.

NORTH, Douglass C. Institutions, Institutional Change and Economic Performance. Cambridge University Press. 1990, 152p.

NORUŠIS, Marija J. SPSS 10.0: Guide to Data Analysis. New Jersey, Prentice Hall, 2000, $577 p$.

NOVA ZELÂNDIA. AgriQuality. Institucional. Disponível em: <http://www.agriquality.co.nz/. Acesso em: 10 set. $2002 a$.

NOVA ZELÂNDIA. The New Zealand Institute of Food Science and Technology - NZIFST Disponível em: <http://www.nzifst.org.nz/>. Acesso em: 10 set. 2002b.

ORGANIZAÇÃO MUNDIAL DA SAÚDE. Codex Alimentarius. Disponível em: $<$ http://www.codexalimentarius.net/>. Acesso em: 2 set. 2002c.

ORGANIZAÇÃO MUNDIAL DA SAÚDE. Institucional. Disponível em: $<$ http://www.who.int/en/>. Acesso em 2 set. 2002a.

ORGANIZAÇÃO MUNDIAL DA SAÚDE.. Food Aid Organization. Disponível em: $<$ http://www.fao.org/>. Acesso em: 2 set. 2002b.

ORGANIZAÇÃO MUNIDAL DO COMÉRCIO. Institucional. Disponível em: <http://www.wto.org/>. Acesso em: 2 set. 2002.

OSBORNE, Martin J.; RUBINSTEIN, Ariel. A Course in Game Theory. Cambridge: The MIT Press. 1994, 352p.;

OSTROM, Elinor, GARDNER, Roy and WALKER, James. Rules, Games and Common Pool Resources. U. Michigan Press. Ann Arbor. 1994. 
OSTROM, Elinor. Collective Action and the Evolution of Social Norms. Journal of Economic Perspectives, v. 14, no. 3, p. 137-158, Summer 2000.

OVERGAARD, Per Baltzer. Moral Hazard in Repeated Quality Selection: An Equilibrium Analysis of Repeated Purchase when Information is both Imperfect and Incomplete. Memo: Working Paper, Aarhus Institute of Economics. Jan. 1990, 38p.

OYARZÚN, María Teresa. Sellos de Calidad en Alimentos, El Caso de la Unión Europea Y de Francia. FAO, Chile. Noviembre 2001.

PENSA. Programa de Estudos dos Negócios do Sistema Agroalimentar. Institucional. Fundação Instituto de Administração, Universidade de São Paulo. Disponível em <http://www.fia.com.br/pensa/> Acesso em: jan: 2003.

PERCEPTUAL. Mapping using SPSS categories. Training Department. Chicago: SPSS Inc. (www.spss.com).

PINHEIRO MACHADO Filho, Cláudio A. Responsabilidade Social Corporativa e a Criação de Valor para as Organizações: Um Estudo Multicasos. Tese (Doutorado em Administração) - Faculdade de Economia, Administração e Contabilidade, Universidade de São Paulo, São Paulo, 2002. 204p.

PIRACICABA. Prefeitura Municipal de Piracicaba. Disponível em: < http://piracicaba2.imagenet.com.br/imprensal. $>$ Acesso em 20 jan. 2003.

PLOTT, Charles. Will Economics Become an Experimental Science? Sixtieth annual meeting of the Southern Economic Association, New Orleans, November 20, 1990, p. 901-919.

POPPO, Laura; ZENGER, Todd. Do Formal Contracts and Relational Governance Function as Substitutes of Complements? Strategic Management Journal., p. 707-725, v. 23, no. 8, 2002.

PORTER, Michael E. Estratégia competitiva: técnicas para análise de indústrias e da concorrência. 5a . ed. Rio de Janeiro: Campus, 1991. 362p.

PORTER, Michael E. Vantagem competitiva: criando e sustentando um desempenho superior. $11^{\mathrm{a}}$. ed. Rio de Janeiro: Campus, 1989. 512p.

POSNER, Richard A. Economic Analysis of Law. Chapter 13: The Choice Between Regulation and Common Law. Fith Edition, Aspen Law \& Business. A Division of Aspen Publisher, Inc. 1998, p. 401-424.

PREFEITURA MUNICIPAL DE PIRACICABA. Disponível em:

http://piracicaba2.imagenet.com.br/imprensal. Acesso em 20 jan. 2003.

PROCON. Fundação Procon de São Paulo. Institucional. Disponível em:

<http://www.procon.sp.gov.br/>. Acesso em: 8 jul. 2002.

REINO UNIDO. Department for Environment Food and Rural Affairs (DEFRA). Institucional. Disponível em: <http://www.defra.gov.uk/default.htm>. Acesso em: 10 set. 2002a.

REINO UNIDO. The Royal Institute of Public Health. Institucional. Disponível em: $<$ http://www.riphh.org.uk/>. Acesso em: 10 set. 2002b.

REINO UNIDO. Ukonline. Institucional. Disponível em: $<$ http://www.ukonline.gov.uk/Home/HOHome/1,1031, 801b22 fs en,00.html>. Acesso em: 10 set. 2002c.

REZENDE, R. V. Brazil: a case study. Food Policy. p.120-130. Apr. 1993. 
RIES, Al;TROUT, Jack; Positioning: The Battle for Your Mind. McGraw Hill: New York, 2000, 246p.

RIVERA, Berta. The effects of public health spending on self-assessed health status: an ordered probit model. Applied Economics. Vol. 33, p. 1313-1319, 2001.

ROBERTS, Cynthia A. The Food Safety Information Handbook. Oryx press, Westport. 2001, 312p.

ROTER'S. The Nature of Trust in Buyer-Seller Relationships. Journal of Marketing, v. 61, p. 35-51, April 1967,.

SAAB, Maria Stella Beregeno Lemos de Melo. Valor Percebido pelo Consumidor: Um Estudo de Atributos da Carne Bovina. Dissertação (Mestrado em Administração) Faculdade de Economia, Administração e Contabilidade, Universidade de São Paulo, 1999, 95p.

SAS, version 8.0. Manual de Ajuda. Disponível em: http://www.sas.com. Acesso em: mar. 2003.

SCHUMANN, Michael S.; SCHNEID, Thomas D.; SCHUMANN, B. R.; FAGEL, Michael J. Food Safety Law. John Wiley \& Sons, Inc. 1997, 325p.

SHETH, Jagdish. N. MITTAL, Banwari. NEWMAN, Bruce I. Contexto do Mercado: economia, Governo e Tecnologia. IN: Comportamento do cliente: indo além do comportamento do consumidor. São Paulo: Atlas, 2001. p.137.

SILVA, Carlos Arthur B. da; BATALHA, Mário Otávio (Coord.). Estudo sobre a Eficiência Econômica e Competitividade da Cadeia Agroindustrial da Pecuária de Corte no Brasil. Consórcio FUNARBE - Universidade Federal de Viçosa e Universidade Federal de São Carlos. Brasília, julho 1999, 552p.

SIQUEIRA, José $O$. Mensuração da estrutura de preferência do consumidor: uma aplicação de conjoint analysis em marketing. São Paulo, 1995. 330p. Dissertação (Mestrado). Faculdade de Economia, Administração e Contabilidade, Universidade de São Paulo.

SMINK, G. C. J.; HAMSTRA, A. M. Impacts of New Biotechnology in Food Production on Consumers (SWONKA, Research Paper 170). The Hague: SWOKA Institute for Consumer Research, 1994.

SMITH, M. E., RAVENSWAAY, E. O. van; THOMPSON, S. R.: Sales loss determination in food contamination incidents: an aplication to milk bans in Hawaii. American Journal of Agriculture Economics, v. 73, n. 3, p.513-520, 1998.

SMITH, Vernon L. Economics in the Laboratory. Journal of Economic Perspectives, 8:113-131, 1994.

SMITH, Vernon L. Microeconomic Systems as an Experimental Science. American Economic Review 72 (December): 923-955 (1982).

SMITH, Vernon L. Theory, experiment and economics. Journal of Economic Perspectives, 3:151-169, 1989.

SMITH, Vernon L.; WHITE, Lawrence H. Reflections on Human Action After 50 Years. CATO Journal, v. 19, n. 2, p. 195-213, Fall 1999.

SPERS, Eduardo E. A Segurança alimentar ao longo da cadeia. Conjuntura Alimentos, v. 5, n. 1, p. 18-26, fev. 1993. 
SPERS, Eduardo E. Preferência do Consumidor por Atributos de Segurança: Aplicação de Conjoint Analysis. Dissertação (Mestrado em Economia Aplicada) - Escola Superior de Agricultura Luiz de Queiroz (ESALQ), Universidade de São Paulo (Orientadora: Ana Lucia Kassouf), 1998, 104p.

SPERS, Eduardo E.; CHADDAD, F. R. Capítulo 3: O Papel da Qualidade na Europa. p. 4774. In. Agribusiness Europeu. Ed. Pioneira, São Paulo, 1996, 132p.

SPERS, Eduardo E.; ZYLBERSZTAJN, Decio. Estudo de Caso Dunguling State. Certificação de Qualidade na Agricultura Australiana. Seminário Internacional PENSA 1999, 33p.

SPRIGGS John; ISAAC Grant. Food Safety and International Competitiveness: The Case of Beef. Cabi Publishing. 2001, 196p.

STATA Statistical Software, Versão 8.0. Manual de Ajuda. Disponível em: http://www.stata.com. Acesso em: mar. 2003.

STIGLER, George. The Economics of Information. Journal of Political Economy. 1961, p. 213-225.

STIGLITZ, Joseph E. Economics of the Public Sector. Third Edition. W. W. Norton \& Company. New York/London, 2000, 823p.

STREETER, D. et al., Information technology, coordination, and competitiviness in the food and agribusiness sector. American Journal of Agriculture Economics, v. 73, n. 5, 14661471, 1991.

SUNSTEIN, Cass R. Behavioral Law \& Economics. Cambridge University Press, Cambridge, United Kingdom, 2000, 421p.

TEIXEIRA, I. Segurança Alimentar Ameaçada. Conjuntura Econômica, v. 35, n. 12, p.109113, dez. 1981.

TIROLE, Jean. The Theory of Industrial Organization. Cambridge: The MIT Press. 13ed., 2002, 479p.

TURNER, Alan. The Future of Food Law. Food Manufacture, v. 75 no. 2, p. 43-45, Feb. 2000.

TYBOR, P. T. Food safety: the issue in the future. Better Crops with Plant Food, p.16-19. Spring 1991.

UE. União Européia. Política de Calidad. Disponível em:

<http://www.europa.eu.int/comm/agriculture/qual>. Acesso em: 10 out. 2002a.

UE. União Européia. Agricultura e Alimentação. Disponível em:

$<$ http://europa.eu.int/comm/agriculture/foodqual/quali pt.htm>. Acesso em: 10 out. 2002b.

UE. União Européia. Council Directive. Oficial Journal of the European Communities. 2003 e anos anteriores.

UNNEVERHR, Laurian J. Food Safety Issues and Fresh Food Product Export from Ldcs. Agricultural Economics, Vol. 23, no. 3, September, 2000.

VINHOLIS, Marcela de Mello Brandão. O Desafio da Rastreabilidade no Mercado Brasileiro de Carne Bovina: Um Estudo Multicaso de Frigoríficos Exportadores. Universidade Federal de São Carlos. Dissertação de Mestrado. 2001, 142p. 
VISCUSI, W. Kip. Consumer Behavior and the Safety Effects of Product Safety Regulation. Journal of Law and Economics, vol. XXVIII, October, 1985, p. 527-553.

WANSINK, Brian; RAY, Michael L. Advertising Strategies to Increase Usage Frequency. Journal of Marketing. Vol. 60, jan. 1996, p. 31-46.

WEIGELT, Keith; CAMERER, Colin. Reputation0, and Corporate Strategy: A Review of Recent Theory and Application. Strategic Management Journal, Sep-out, 1988, vol. 9, no. 5, p. 443-454.

WILLIAMSON, Oliver E. The Economic Institutions of Capitalism. New York: The Free Press, 1985, 450p.

WILLIAMSON, Oliver E. The Mechanisms of Governance. New York: Oxford University Press, 1996, 429p.

ZYLBERSZTAJN, D. Estruturas de Governança e Coordenação do Agribusiness: uma aplicação da nova economia das instituições. São Paulo, 1995. 214p. Tese (Livre docência) - Faculdade de Economia, Administração e Contabilidade, Universidade de São Paulo. 


\section{ANEXOS}

A - Legislações e regulamentos sobre segurança e qualidade dos alimentos.

\begin{tabular}{|c|c|c|c|}
\hline Área & Preocupação & Legislação & Fonte \\
\hline $\begin{array}{l}\text { Engenharia } \\
\text { Genética }\end{array}$ & $\begin{array}{l}\text { Avanços no campo da } \\
\text { engenharia genética como } \\
\text { os alimentos ou } \\
\text { organismos } \\
\text { geneticamente } \\
\text { modificados (OGMs) }\end{array}$ & $\begin{array}{l}\text { Brasil, Legislação sobre } \\
\text { Biossegurança: Lei } 8.974 / 95, \\
\text { alterada pela Medida Provisória } \\
2.137 \text {, de } 20 \text { de dezembro de } \\
2000 \text { e do Decreto } 1.752 / 95 \text {. }\end{array}$ & $\begin{array}{l}\text { - PORTAL BIOTECNOLOGIA. Disponível em: } \\
\text { <http://www.biotecnologia.com.br/biojuridico/jurp } \\
\text { areceres.htm>. Acesso em: } 16 \text { ago. } 2002 \text {. } \\
\text { - FORMANEK Jr, Raymond. Proposed Rules } \\
\text { Issued For Bioengineered Foods. FDA } \\
\text { Consumer. p. 9-11, March-April, } 2001 .\end{array}$ \\
\hline $\begin{array}{l}\text { Processo de } \\
\text { produção }\end{array}$ & $\begin{array}{l}\text { Controle dos Riscos de } \\
\text { Fabricação do Alimento }\end{array}$ & $\begin{array}{l}\text { Portaria MS n० } 1.428 \text { e } \\
\text { Resoluções RDC números 12, } \\
17 \text { e 18. Análise dos Perigos e } \\
\text { Pontos Críticos de Controle } \\
\text { (APPCC) e as Boas Práticas } \\
\text { de Fabricação }\end{array}$ & $\begin{array}{l}\text { - BRASIL, Agência Nacional de Vigilância } \\
\text { Sanitária (ANVISA). } \\
\text { <http://www.anvisa.gov.br/legis/index.htm>. } \\
\text { Acesso em: } 2 \text { set. } 2002 \text {. }\end{array}$ \\
\hline $\begin{array}{l}\text { Conservaçã } \\
\text { o de } \\
\text { alimentos }\end{array}$ & Irradiação de alimentos & & $\begin{array}{l}\text { - DULEN, Jacqueline. Food Safety: Industry } \\
\text { Awaits Irradiation Rules. Restaurants and } \\
\text { Institutions. January 15, 1999. p. } 76 .\end{array}$ \\
\hline Nutrição & Adequada alimentação & Resolução RDC número 21. & $\begin{array}{l}\text { - BRASIL, Agência Nacional de Vigilância } \\
\text { Sanitária (ANVISA). Disponível em: } \\
\text { <http://www.anvisa.gov.br/legis/index.htm>. } \\
\text { Acesso em: } 2 \text { set.2002. }\end{array}$ \\
\hline $\begin{array}{l}\text { Produção e } \\
\text { Tratos com } \\
\text { os Animais }\end{array}$ & Bem-estar animal & FAIR programe. 2002 & $\begin{array}{l}\text { - HARPER, Gemma C.; MEEHAN, Hilary F.; } \\
\text { Henson, Spencer J.; Cowan, Cathal. Consumer } \\
\text { Concerns about Farm Animal Welfare, Food } \\
\text { Safety and Product Quality. Projeto da European } \\
\text { Commission's FAIR programe. 2002, 32p. }\end{array}$ \\
\hline $\begin{array}{l}\text { Informação e } \\
\text { Rotulagem }\end{array}$ & $\begin{array}{l}\text { Correta informação sobre } \\
\text { os alimentos funcionais ou } \\
\text { nutracêutica e as suas } \\
\text { propriedades terapêuticas. }\end{array}$ & $\begin{array}{l}\text { Portaria No. } 841 \text { da Vigilância } \\
\text { Sanitária quanto ao Registro de } \\
\text { Alimentos com Alegações de } \\
\text { Propriedades Funcionais em } \\
\text { sua Rotulagem e Resoluções } \\
\text { números } 18,19 \text { e } 449 \text { e RDC } \\
\text { no. } 2 \text {. }\end{array}$ & $\begin{array}{l}\text { - BRASIL, Agência Nacional de Vigilância } \\
\text { Sanitária (ANVISA). Disponível em: } \\
\text { <http://www.anvisa.gov.br/legis/index.htm>. } \\
\text { Acesso em: } 2 \text { set. } 2002 \text {. }\end{array}$ \\
\hline $\begin{array}{l}\text { Comercializa } \\
\text { ção e } \\
\text { Produção de } \\
\text { Alimentos }\end{array}$ & $\begin{array}{l}\text { Correta produção e } \\
\text { comercialização dos } \\
\text { alimentos }\end{array}$ & $\begin{array}{l}\text { Portaria No. } 839 \text { da Vigilância } \\
\text { Sanitária quanto às Diretrizes } \\
\text { Básicas para Validação de } \\
\text { Risco e Segurança dos } \\
\text { Alimentos. }\end{array}$ & $\begin{array}{l}\text { - BRASIL, Agência Nacional de Vigilância } \\
\text { Sanitária (ANVISA). Disponível em: } \\
\text { <http://www.anvisa.gov.br/legis/index.htm>,. } \\
\text { Acesso em: } 2 \text { set. } 2002 \text {. }\end{array}$ \\
\hline $\begin{array}{l}\text { Rastreabilida } \\
\text { de }\end{array}$ & $\begin{array}{l}\text { Identificação da Origem e } \\
\text { Barrerias Não Tarifárias }\end{array}$ & $\begin{array}{l}\text { Sistema Brasileiro de } \\
\text { Identificação e Certificação de } \\
\text { Origem Bovina e Bubalina } \\
\text { (SISBOV). }\end{array}$ & $\begin{array}{l}\text { - BRASIL, Ministério da Agricultura e do } \\
\text { Abastecimento (MARA). Departamento de } \\
\text { Inspeção de Produtos de Origem Animal } \\
\text { (DIPOA). Disponível em: } \\
\text { <http://www.agricultura.gov.br/sda/dipoa/instnor } \\
\text { m21 2002.htm>. Acesso em: } 2 \text { set. } 2002 \text {. }\end{array}$ \\
\hline Inspeção & $\begin{array}{l}\text { Verificação da Adoção das } \\
\text { Normas e o "fazer } \\
\text { cumprir". }\end{array}$ & $\begin{array}{l}\text { Altera o Serviço de Inspeção } \\
\text { Federal (SIF). Lei no. } 7.889 \text { de } \\
\text { 1989. }\end{array}$ & $\begin{array}{l}\text { - BRASIL, Ministério da Agricultura e do } \\
\text { Abastecimento (MARA). Departamento de } \\
\text { Inspeção de Produtos de Origem Animal } \\
\text { (DIPOA). Disponível em: } \\
\text { <http://www.agricultura.gov.br/sda/dipoa/>. } \\
\text { Acesso em: } 2 \text { set. } 2002 \text {. }\end{array}$ \\
\hline $\begin{array}{l}\text { Varejo e } \\
\text { Restaurante } \\
\text { s }\end{array}$ & $\begin{array}{l}\text { Venda de produto } \\
\text { impróprio, adulterado, } \\
\text { clandestino ou fora do } \\
\text { prazo de validade. }\end{array}$ & Vigilância Sanitária & $\begin{array}{l}\text { - BRASIL, Agência Nacional de Vigilância } \\
\text { Sanitária (ANVISA). Disponível em: } \\
\text { <http://www.anvisa.gov.br/legis/index.htm>,. } \\
\text { Acesso em: } 2 \text { set. } 2002 \text {. } \\
\text { - Supermercado Moderno, } 1995 \text {. }\end{array}$ \\
\hline
\end{tabular}

Fonte: 0 autor. 
B - Agências Federais Norte Americanas com funções de segurança do alimento

\begin{tabular}{|c|c|c|}
\hline Agência & Departamento & Função sobre a segurança do alimento \\
\hline Agricultural Marketing Service (AMS) & USDA & Classifica produtos alimentares \\
\hline Agricultural Research Service (ARS) & USDA & Pesquisa para resolver problemas agrícolas \\
\hline Alcohol, Tobacco and Firearms & Treasury & Licencia e inspeciona bebida e destilarias \\
\hline $\begin{array}{c}\text { Animal and Plant Health Inspection } \\
\text { Services (APHIS) }\end{array}$ & USDA & $\begin{array}{l}\text { Controla e erradica pestes e doenças em plantas e } \\
\text { animais }\end{array}$ \\
\hline Center for Disease Control (CDC) & $\mathrm{HHS}$ & Vigia e investiga doenças relacionadas aos alimentos \\
\hline $\begin{array}{l}\text { Cooperative State Research, Education } \\
\text { and Extension Service (CREES) }\end{array}$ & USDA & $\begin{array}{l}\text { Educa o público sobre aspectos dos alimentos e } \\
\text { patrocina os pesquisadores universitários sobre } \\
\text { programas de pesquisa agrícola }\end{array}$ \\
\hline Economic Research Service (ERS) & USDA & $\begin{array}{l}\text { Pesquisa e analisa problemas relacionados dos } \\
\text { alimentos }\end{array}$ \\
\hline Environmental Protection Agency (EPA) & - & $\begin{array}{l}\text { Avalia os riscos, aprova produtos, define tolerâncias e } \\
\text { pesquisa sobre resíduos pesticidas em ou sobre os } \\
\text { alimentos humanos e animais. }\end{array}$ \\
\hline Food and Drug Administration (FDA) & HHS & $\begin{array}{l}\text { Garante que o produto é seguro, puro e salutar; cobre } \\
\text { todos os alimentos, exceto carnes, aves e ovos os } \\
\text { quais são regulados pelo FSIS. }\end{array}$ \\
\hline $\begin{array}{l}\text { Food Safety and Inspection Services } \\
\text { (FSIS) }\end{array}$ & USDA & $\begin{array}{l}\text { Regula produtos como carnes, aves e ovos por meio } \\
\text { de contínuas inspeções para garantir que os produtos } \\
\text { procedentes do comércio interestadual e exterior são } \\
\text { seguros, salutares, não adulterados e corretamente } \\
\text { rotulados. }\end{array}$ \\
\hline $\begin{array}{l}\text { Grain Inspection, Packers, and } \\
\text { Stockyards Administration (GIPS) }\end{array}$ & USDA & $\begin{array}{l}\text { Estabelece padrões para grãos e outras commodities } \\
\text { administradas e inspecionadas nacionalmente }\end{array}$ \\
\hline National Institutes of Health $(\mathrm{NIH})$ & $\mathrm{HHS}$ & $\begin{array}{l}\text { Conduz pesquisas relacionadas a doenças } \\
\text { alimentares. }\end{array}$ \\
\hline $\begin{array}{l}\text { National Marine Fisheries Service } \\
\text { (NMFS) }\end{array}$ & Commerce & $\begin{array}{l}\text { Conduz inspeções voluntárias e programas de } \\
\text { padronização e realiza pesquisa sobre a segurança de } \\
\text { frutos do mar. }\end{array}$ \\
\hline
\end{tabular}

Fonte: Documentos Governamentais do Governo dos Estados Unidos apud Hogan Jr., Harold F. The Safe Food Act: A Consumer Group's Perspective. Case Study. Harvard Business School. 1999, 20p.

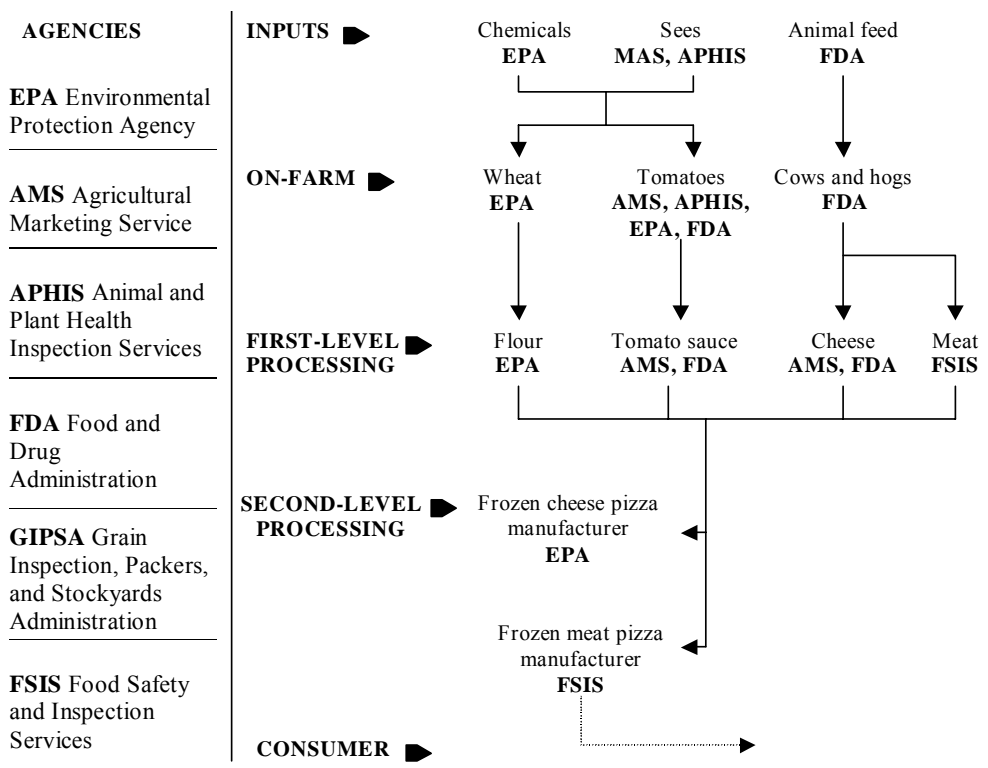

Fonte: Hogan Jr., 1999, p. 18. 


\section{C - Modelos de comunicação sobre saúde.}

Modelo de comunicação sobre a ameaça à saúde: descreve as mudanças na $\quad$ Higbee (1969); Leventhal (1970)

cognição sobre a saúde por meio do uso da comunicação de ameaças.

Modelo de comunicação persuasiva: descreve a interpretação e receptividade $\quad$ McGuire (1981); Petty and Cacioppo (1986)

da comunicação persuasiva como uma função da mensagem e da

característica do receptor.

Modelo da difusão da inovação: teoriza que os padrões de adoção da inovação $\quad$ Rogers (1983); Smith, Olshalavsky, and Smith

na saúde dependem do aceite e da comunicação das lideranças de opinião

(1979)

\section{B. Modelos sociais:}

Modelos sócio-culturais: avalia o impacto cultural, sub-cultural, normas de grupos, estilo de vida e fatores sócio-culturais sobre o comportamento em relação à saúde.

Modelos educativos de autorização: ilustra como a participação de grupos e ações da comunidade aumenta as crenças na habilidade de mudar comportamentos em relação à saúde

\section{Modelos cognitivos:}

Modelo de crença em saúde: foco sobre a percepção do benefício à saúde, percepção do tratamento do perigo e percepção interna e externa sobre as sugestões de ações como determinantes.

Modelo de utilidade percebida: prediz a escolha das ações relacionadas à saúde com utilidade alta utilidade percebida.

Behavioral intention models: explore relationships between attitudes e health

behaviors with behavioral intention as a mediator

Modelo de consciência sobre a saúde: investiga o envolvimento com a saúde

monitoramento próprio e medo como determinantes.

\section{Modelos comportamentais:}

Teoria do aprendizado social: foca o papel dos modelos comportamentais, necessidade de desenvolver habilidades e encorajar a eficácia própria.

Modelo de controle pontual da saúde: teoriza sobre os efeitos da orientação saúde (grau no qual o benefício da saúde resulta do esforço pessoal, chance de provedores de assistência à saúde ou tratamentos gerais).

Modelos comportamentais modificados: usa técnicas operacionais condicionadas para influenciar o comportamento de saúde.

\section{E. Modelos de marketing:}

Estrutura contingencial: sugere que a relação do provedor e receptor da saúde difere dependendo do poder da fonte.

Modelo de marketing social: teoriza que a manipulação das variáveis do marketing mix podem motivar o comportamento sobre a saúde.

Modelo de utilização da informação sobre saúde: teoriza sobre os efeitos das características da informação e do consumidor sobre a cognição e as atividades comportamentais.

F. Modelos combinados:

Modelo de comportamento de regulação própria: teoriza que variáveis pessoais comportamentais e ambientais influenciam o comportamento sobre a saúde.

Modelo PRECEDE: classifica a influência da saúde com os fatores de predisposição (conhecimento por exemplo) fatores de capacitação (ambiente por exemplo) e fatores de reforço.

Modelo de motivação de potencial de capacitação: foca sobre a imagem da mudança do comportamento sobre a saúde e o papel de estruturas de suporte em iniciar e manter o comportamento sobre a saúde.

Modelo de interação dinâmica pessoal: estressa a relação recíproca entre os determinantes situacionais e pessoais do comportamento sobre a saúde. Modelo de proteção-motivação e adaptabilidade e não adaptabilidade sobre cobertura de saúde: modelo de fontes de informação e processo de intermediação cognitiva (como a eficácia da percepção e responsabilidade própria) como determinante da adaptabilidade ou não adaptabilidade das estratégias de cobertura sobre a saúde.

Modelo de avaliação das estratégias de saúde em marketing: inclui variáveis psicológicas, sociais e comportamentais como determinantes do comportamento sobre a saúde em países em desenvolvimento. Modelo de promoção da saúde: consiste de elementos cognitivos de percepção, fatores de modificação do ambiente e outras fontes de ação como determinantes da sugestão de ação como a saúde

Bullough (1972); Coburn and Pope (1974); Langlie (1977)

Friere (1983); Wallerstein and Bernstein (1988)

Becker (1974); Janz and Becker (1984);

Rosenstock (1974)

Cohen (1984); March and Matheson (1983)

Ajzen and Madden (1986); Fishbein and Ajzen (1975); Fishbein and Jaccard (1973)

Gould (1990)

Bandura (1977, 1986)

Lau (1982, 1988); Lau and Ware (1981);

Wallston and Wallston (1982)

Davidson and Davidson (1980); Pomeiau, Bass, and Crown (1975)

Friedman and Churchill (1987)

Gelb and Gilly (1979); Kotler and Zaltman

(1971)

Cole and Gaeth (1990; Moorman (1990; Russo

el al. (1986); Scammon (1977)

Clark and Zimmerman (1990)

Anderson and Newman (1973); Smith and

Scammon (1986)

Fleury (1991)

Levy (1991)

Rippetoe and Rogers (1987)

Fonte: Adaptado de Moorman e Matulich, 1993, op. cit 


\section{D - Divisão do município de Piracicaba em regiões.}

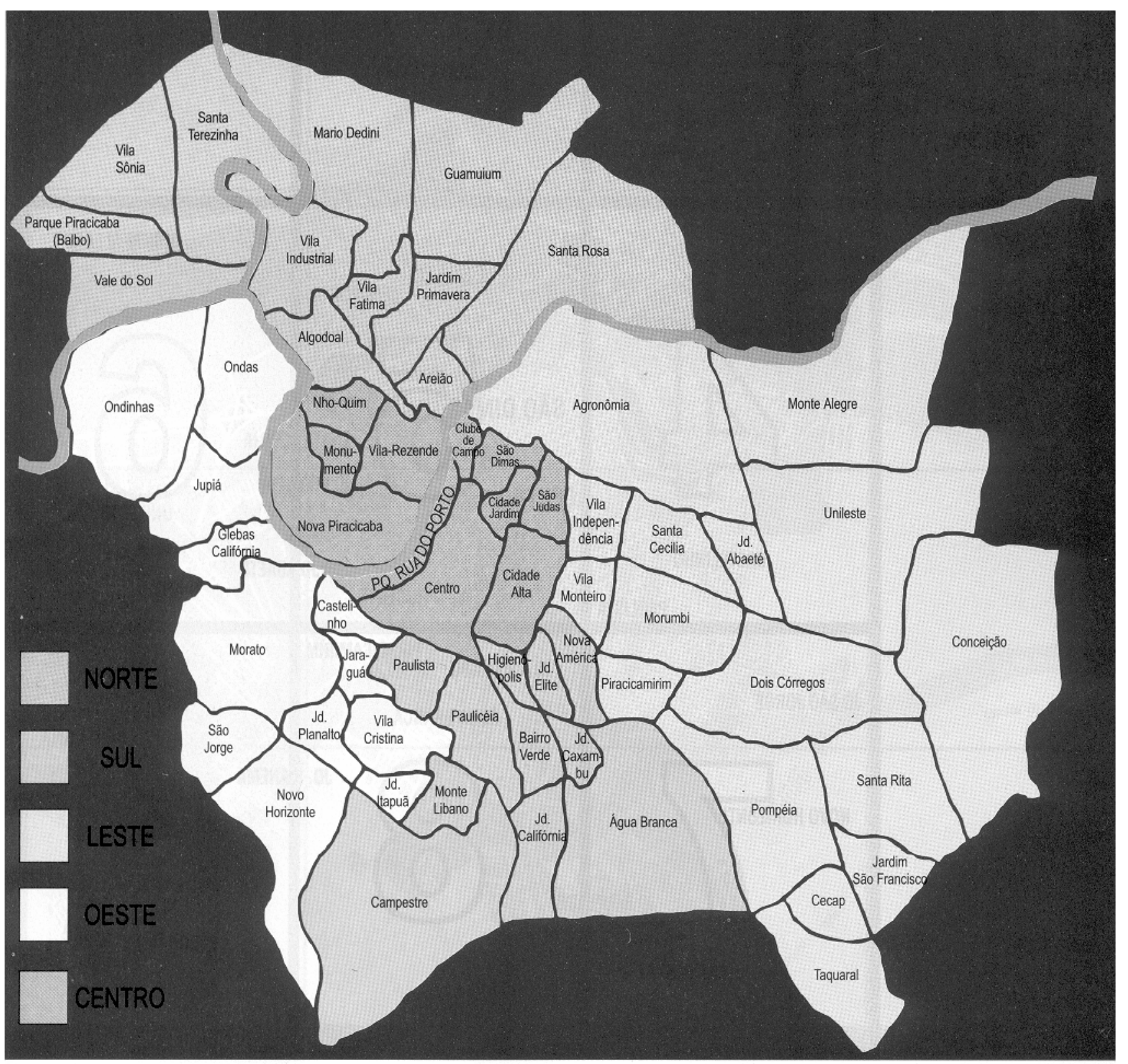

Fonte: Prefeitura Municipal de Piracicaba, 2003 


\section{E - Informações sobre o procedimento de amostragem}

\begin{tabular}{|c|c|c|c|c|c|c|c|c|c|c|c|}
\hline \multirow[t]{2}{*}{ Região } & \multicolumn{3}{|c|}{ População do Município } & \multicolumn{4}{|c|}{ Açougues } & \multicolumn{4}{|c|}{ Supermercados } \\
\hline & $1999^{* *}$ & $2000^{* *}$ & $\begin{array}{c}2000 \\
(\mathrm{em} \%)\end{array}$ & Total* & $\begin{array}{l}\text { Total } \\
(\mathrm{em} \%)\end{array}$ & Pesquisados & $\begin{array}{l}\text { Pesquisados } \\
\text { (em \% do total) }\end{array}$ & Total $^{*}$ & $\begin{array}{l}\text { Total } \\
(\mathrm{em} \%)\end{array}$ & Pesquisados & $\begin{array}{l}\text { Pesquisados } \\
\text { (em \% do total) }\end{array}$ \\
\hline Norte & 47.344 & 68.935 & 22,31 & 20 & 12,74 & 2 & 10,00 & 16 & 17,02 & 2 & 12,50 \\
\hline Leste & 46.369 & 58.376 & 18,89 & 16 & 10,19 & 7 & 43,75 & 19 & 20,21 & 4 & 21,05 \\
\hline Oeste & 39.331 & 51.074 & 16,53 & 15 & 9,55 & 4 & 26,67 & 21 & 22,34 & 2 & 9,52 \\
\hline Sul & 52.560 & 67.356 & 21,79 & 28 & 17,83 & 4 & 14,29 & 18 & 19,15 & 3 & 16,67 \\
\hline
\end{tabular}

Fonte: Dados fornecidos pela Secretaria Municipal de Planejamento de Piracicaba (SEMUPLAN)* e Censo do Instituto Brasileiro de Geografia e Estatística (IBGE) de 1991 e 2000**.

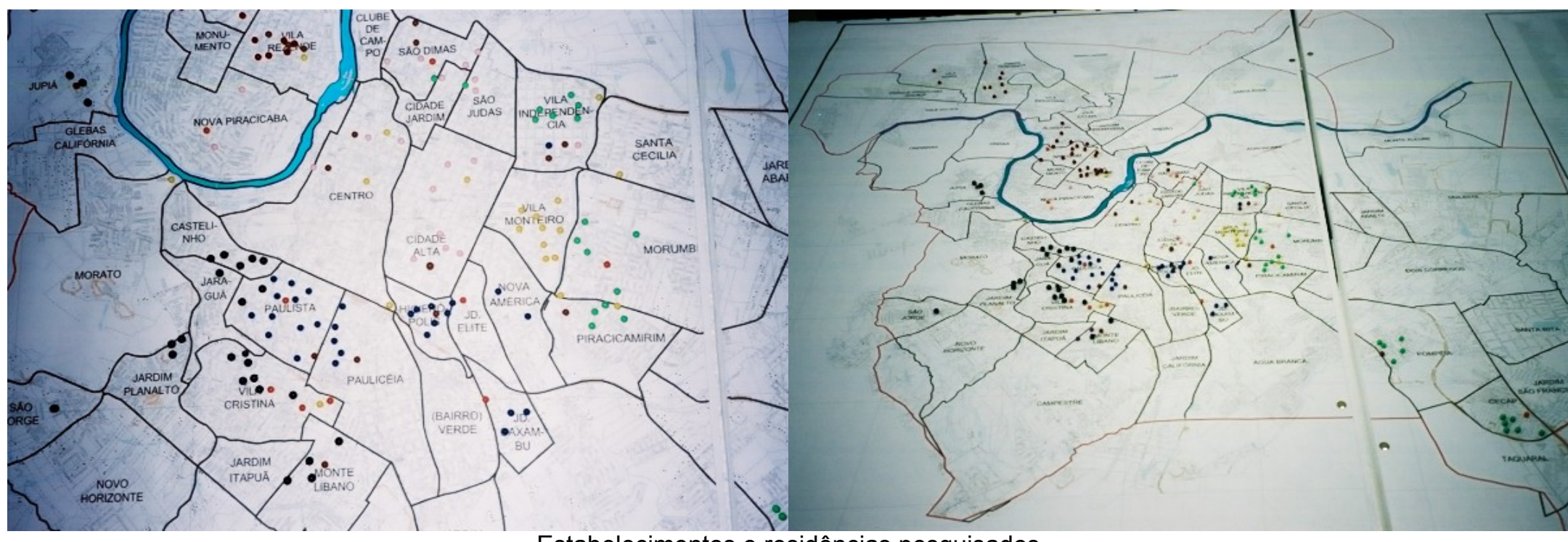

Estabelecimentos e residências pesquisados 


\section{F - Questionário aplicado aos consumidores.}

É consumidor e comprador de carne bovina? Se não for selecionar outro entrevistado 1) Local da Entrevista:

Ou ( ) Supermercado. Nome: No. de referência

Ou ( ) Açougue. Nome:

Ou ( ) Residência. Rua: No. de referência

2) Estabelecimentos onde compra carne. ( ) Açougue ( ) Supermercado No.

3) Costuma comprar carne em um único estabelecimento? ( ) Sim ( ) Não

4) Quais os motivos que o levam a escolher o local de compra?

\begin{tabular}{|l|c|}
\hline Proximidade & $($ ) \\
\hline Confiança no estabelecimento & $($ ) \\
\hline Intensidade da fiscalização & $($ ) \\
\hline Qualidade da carne & $($ ) \\
\hline Preço & $($ ) \\
\hline Outro ( & $($ ) \\
\hline
\end{tabular}

2) Número de dias na semana em que consome carne bovina: ( ) 1( ) 2( ) 3 ( ) 4 ou +

3) Primeiro nome:

5) Bairro onde reside:

4) Telefone para contato:

7) Idade em anos: ( ) Até 20 ( ) 20 a 30 ( ) 30 a 40 ( ) 40 a 50 ( ) + que 50

8) Trabalha: ( ) Não ( ) Sim Ocupação:

9) Imóvel onde mora: ( ) Próprio ( ) Alugado 10) Possui automóvel: ( ) Nenhum ( ) 1 ( ) 2 ou +

11) Possui computador: ( ) Sim ( ) Não 12) Estado Civil: ( ) Solteiro(a) ( ) Casado(a) ( ) Outro

13) Número de pessoas com quem reside: ( ) 1 ( ) 2 ( ) 3 ( ) 4 ( ) 5 ou +

14) Renda familiar em $R \$$ :

( ) Até 500 ( ) 501 a 1000 ( ) 1001 a 1500 ( ) 1501 a 2000 ( ) 2001 a 2500 ( ) 2501 a 3000 ( ) 3001 ou +

15) Grau de Instrução:

\begin{tabular}{|l|l|}
\hline Analfabeto ou Primário incompleto & - \\
\hline Primário completo ou Ginásio incompleto & \\
\hline Ginásio completo ou Colegial incompleto & \\
\hline Colegial completo ou Superior incompleto & \\
\hline Superior completo & \\
\hline
\end{tabular}

Primário $=1^{\mathrm{a}}$ a $4^{\mathrm{a}}$ série do $1^{\circ}$ grau $/$ Ginásio $=5^{\mathrm{a}}$ a $8^{\mathrm{a}}$ série do $1^{\circ} \mathrm{grau} /$ Colegial $=1^{\mathrm{a}}$ a $3^{\mathrm{a}}$ série do $2^{\mathrm{a}}$ grau $/$ Superior $=$ Faculdade 16) Coloque o seu conhecimento sobre:

\begin{tabular}{|l|c|c|}
\hline & Não Conhece & Conhece \\
\hline O Serviço de Inspeção Federal (SIF) & $($ ) & $($ ) \\
\hline $\begin{array}{l}\text { As substâncias utilizadas na produção da } \\
\text { carne bovina como hormônios de crescimento }\end{array}$ & $($ ) & $($ ) \\
\hline $\begin{array}{l}\text { As possíveis doenças causadas pela ingestão } \\
\text { de carne bovina contaminada }\end{array}$ & $($ ) & $($ ) \\
\hline $\begin{array}{l}\text { A entidade de fiscalização "Vigilância } \\
\text { Sanitária" }\end{array}$ & $($ ) & $($ ) \\
\hline
\end{tabular}

17) Assinale três características que, na sua opinião, melhor contribuem para uma melhor percepção da alta qualidade da carne:

\begin{tabular}{|l|c|}
\hline Local de compra & $($ ) \\
\hline Carne com embalagem & $($ ) \\
\hline Fiscalização intensiva & $($ ) \\
\hline Marca do produtor da carne & $($ ) \\
\hline Legislação rigorosa & $($ ) \\
\hline Marca do açougue ou supermercado & $($ ) \\
\hline Preço alto da carne & $($ ) \\
\hline Certificado ou selo & $($ ) \\
\hline Educação e conhecimento do consumidor & $($ ) \\
\hline
\end{tabular}




\section{G - Questionário aplicado aos agentes privados: açougues e supermercados.}

1) ( ) Açougue ( ) Supermercado

2) Nome:

( ) número de referência

3) Na sua opinião, o consumidor se preocupa com a qualidade da carne que compra?

$$
\text { ( ) Sim ( ) Não }
$$

4) Na sua opinião, o consumidor pagaria mais por uma carne de melhor qualidade?

$$
\text { ( ) Sim ( ) Não }
$$

5) Você estaria disposto a investir em uma marca própria de carne?

$$
\text { ( ) Sim ( ) Não }
$$

6) Você estaria disposto a investir em propaganda que evidenciasse a qualidade da carne comercializada em seu estabelecimento?

$$
\text { ( ) } \operatorname{Sim}(\text { ) Não }
$$

7) Qual o grau de rigor da legislação nacional relacionada à garantia da qualidade da carne?

$$
\text { ( ) Alto ( ) Médio ( ) Baixo }
$$

8) Qual o grau de eficiência da fiscalização da vigilância sanitária?

$$
\text { ( ) Alto ( ) Médio ( ) Baixo }
$$

9) Quais as ações que você poderia desenvolver ou desenvolve para melhorar a percepção do consumidor quanto à qualidade e segurança da carne?

10) Quais as ações que o governo poderia desenvolver ou desenvolve para melhorar a percepção do consumidor quanto à qualidade e segurança da carne?

Deseja receber um resumo do trabalho: ( ) Sim ( ) Não

Dados para o envio: Nome:

Endereço: no.

CEP: 
H - Índices de preços de carnes de média e alta qualidade em supermercados de Piracicaba.

\begin{tabular}{|c|c|c|c|c|c|c|c|c|c|c|c|c|c|c|c|c|}
\hline \multicolumn{17}{|c|}{ Supermercado na Região Norte } \\
\hline Carne & $06 /$ nov & $08 /$ nov & $11 /$ nov & $13 /$ nov & $15 /$ nov & $18 /$ nov & $20 /$ nov & $22 /$ nov & $25 /$ nov & 27/nov & $29 /$ nov & $02 / \mathrm{dez}$ & 04/dez & $06 / \mathrm{dez}$ & 09/dez & Média \\
\hline Patinho & 100,00 & 100,00 & 100,00 & 100,00 & 100,00 & 110,17 & 110,17 & 95,38 & 95,38 & 106,16 & 115,41 & 115,41 & 110,79 & 115,41 & 115,41 & 107,47 \\
\hline Alcatra & 122,50 & 122,50 & 122,50 & 127,73 & 96,76 & 127,73 & 129,43 & 138,52 & 138,52 & 138,52 & 138,52 & 138,52 & 138,52 & 138,52 & 138,52 & 132,49 \\
\hline Diferença & 22,50 & 22,50 & 22,50 & 27,73 & $-3,24$ & 17,57 & 19,26 & 43,14 & 43,14 & 32,36 & 23,11 & 23,11 & 27,73 & 23,11 & 23,11 & 25,01 \\
\hline Carne & 11/dez & 13/dez & 16/dez & 18/dez & 20/dez & 23/dez & 27/dez & 30/dez & 03/jan & 06/jan & 08/jan & 10/jan & 13/jan & 15/jan & 17/jan & Média \\
\hline Patinho & 115,41 & 115,41 & 115,41 & 115,41 & 115,41 & 115,41 & 115,41 & 101,54 & 101,54 & 101,54 & 107,70 & 107,70 & 107,70 & 107,70 & 115,41 & 109,37 \\
\hline Alcatra & 138,52 & 138,52 & 138,52 & 138,52 & 130,82 & 130,82 & 130,82 & 149,31 & 149,31 & 149,31 & 148,69 & 148,69 & 148,69 & 130,82 & 132,36 & 140,68 \\
\hline Diferença & 23,11 & 23,11 & 23,11 & 23,11 & 15,41 & 15,41 & 15,41 & 47,77 & 47,77 & 47,77 & 40,99 & 40,99 & 40,99 & 23,11 & 16,95 & 31,30 \\
\hline
\end{tabular}

\begin{tabular}{|c|c|c|c|c|c|c|c|c|c|c|c|c|c|c|c|c|}
\hline \multicolumn{17}{|c|}{ Supermercado na Região Leste } \\
\hline $\begin{array}{l}\text { Data } \\
\text { Carne }\end{array}$ & $06 /$ nov & $08 /$ nov & $11 /$ nov & $13 /$ nov & $15 /$ nov & $18 /$ nov & 20/nov & $22 /$ nov & $25 /$ nov & $27 /$ nov & $29 /$ nov & 02/dez & $04 / d e z$ & 06/dez & 09/dez & Média \\
\hline Patinho & 100,00 & 104,01 & 104,01 & 104,01 & 104,01 & 104,01 & 104,01 & 107,70 & 104,01 & 107,70 & 107,70 & 107,70 & 107,70 & 107,70 & 107,70 & 105,46 \\
\hline Alcatra & 121,57 & 100,00 & 125,58 & 25,58 & 125,58 & 125,58 & 125,58 & 125,58 & 125,58 & 121,57 & 121,57 & 121,57 & 121,57 & 121,57 & 121,57 & 122,00 \\
\hline Diferença & 21,57 & $-4,01$ & 21,57 & 21,57 & 21,57 & 21,57 & 21,57 & 17,87 & 21,57 & 13,87 & 13,87 & 13,87 & 13,87 & 13,87 & 13,87 & 16,54 \\
\hline $\begin{array}{c}\text { Data } \\
\text { Carne }\end{array}$ & 11/dez & 13/dez & 16/dez & 18/dez & 20/dez & 23/dez & $27 / d e z$ & 30/dez & 03/jan & 06/jan & 08/jan & 10/jan & 13/jan & 15/jan & $17 /$ jan & Média \\
\hline Patinho & 107,70 & 107,70 & 107,70 & 107,70 & 107,70 & 107,70 & 107,70 & 107,70 & 107,70 & 107,70 & 107,70 & 107,70 & 107,70 & 107,70 & 107,70 & 107,70 \\
\hline Alcatra & 121,57 & 121,57 & 121,57 & 121,57 & 121,57 & 121,57 & 121,57 & 121,57 & 121,57 & 121,57 & 121,57 & 121,57 & 121,57 & 121,57 & 121,57 & 121,57 \\
\hline Diferença & 13,87 & 13,87 & 13,87 & 13,87 & 13,87 & 13,87 & 13,87 & 13,87 & 13,87 & 13,87 & 13,87 & 13,87 & 13,87 & 13,87 & 13,87 & 13,87 \\
\hline
\end{tabular}

\begin{tabular}{|c|c|c|c|c|c|c|c|c|c|c|c|c|c|c|c|c|}
\hline \multicolumn{17}{|c|}{ Supermercado na Região Oeste } \\
\hline Carne & $06 /$ nov & $08 /$ nov & $11 /$ nov & $13 /$ nov & $15 /$ nov & $18 /$ nov & $20 /$ nov & $22 /$ nov & $25 / \mathrm{nov}$ & $27 /$ nov & $29 /$ nov & $02 / \mathrm{dez}$ & 04/dez & $06 / \mathrm{dez}$ & $09 / \mathrm{dez}$ & Média \\
\hline Patinho & 100,00 & 137,13 & 100,00 & 100,00 & 110,17 & 115,41 & 115,41 & 115,41 & 107,70 & 115,41 & 115,41 & 115,41 & 115,41 & 115,41 & 115,41 & 112,91 \\
\hline Alcatra & 122,50 & 137,13 & 127,73 & 127,73 & 136,36 & 138,52 & 138,52 & 121,57 & 138,52 & 138,52 & 138,52 & 138,52 & 138,52 & 138,52 & 138,52 & 134,65 \\
\hline Diferença & 22,50 & 0,00 & 27,73 & 27,73 & 26,19 & 23,11 & 23,11 & 6,16 & 30,82 & 23,11 & 23,11 & 23,11 & 23,11 & 23,11 & 23,11 & 21,74 \\
\hline Data & 11/dez & 13/dez & 16/dez & 18/dez & 20/dez & 23/dez & $27 / \mathrm{dez}$ & 30/dez & 03/jan & 06/jan & 08/jan & 10/jan & 13/jan & $15 /$ jan & 17/jan & Média \\
\hline Patinho & 115,41 & 115 , & 115, & & & 115, & & 105,55 & & & & & &, 70 & 115,41 & 09,93 \\
\hline Alcatra & 138,52 & & & & & 130,82 & & & & & & & & & & 3,09 \\
\hline Diferença & 23,11 & 15,41 & 15,41 & 15,41 & 15,41 & 15,41 & 15,41 & 62,40 & 25,27 & 2,16 & 44,84 & 23,11 & 23,11 & 23,11 & 27,73 & 23,15 \\
\hline
\end{tabular}

Índice: preço da carne tipo "patinho" em 06 de novembro de 2002 sendo igual a 100 para cada supermercado respectivamente

Fonte: Projeto Cesta Básica: Cálculo do Custo da Cesta Básica de Produtos para o Município de Piracicaba

Faculdade de Gestão e Negócios, UNIMEP, 2003. 


\section{I - Cartões mostrados ao consumidor para ordenação.}

Esta pesquisa lida com a sua preferência sobre determinadas características que estão relacionadas à sua percepção sobre a garantia da qualidade e a segurança da carne bovina: o preço, a marca e o órgão fiscalizador governamental. Serão apresentados a você nove produtos hipotéticos que são carnes consideradas "de primeira" (alcatra ou picanha). Esses produtos foram construídos a partir de três intensidades diferentes dos três seguintes atributos: preço, intensidade da fiscalização e conhecimento sobre a marca.

Por favor, coloque na ordem decrescente de sua preferência os produtos com os atributos que Ihe proporcionam uma maior a uma menor percepção de garantia da qualidade e da segurança do produto.

\begin{tabular}{|c|c|c|}
\hline $\begin{array}{c}\text { Preço em Reais } \\
\text { por quilo }\end{array}$ & $\begin{array}{c}\text { Intensidade da } \\
\text { Fiscalização }\end{array}$ & $\begin{array}{c}\text { Conhecimento } \\
\text { sobre a Marca }\end{array}$ \\
\hline 12,00 & Média & Médio \\
\hline
\end{tabular}

\begin{tabular}{|c|c|c|}
\hline $\begin{array}{c}\text { Preço em Reais } \\
\text { por quilo }\end{array}$ & $\begin{array}{c}\text { Intensidade da } \\
\text { Fiscalização }\end{array}$ & $\begin{array}{c}\text { Conhecimento } \\
\text { sobre a Marca }\end{array}$ \\
\hline 16,00 & Alta & Médio \\
\hline
\end{tabular}

\begin{tabular}{|c|c|c|}
\hline $\begin{array}{c}\text { Preço em Reais } \\
\text { por quilo }\end{array}$ & $\begin{array}{c}\text { Intensidade da } \\
\text { Fiscalização }\end{array}$ & $\begin{array}{c}\text { Conhecimento } \\
\text { sobre a Marca }\end{array}$ \\
\hline $\mathbf{8 , 0 0}$ & Baixa & Médio \\
\hline
\end{tabular}

\begin{tabular}{|c|c|c|}
\hline $\begin{array}{c}\text { Preço em Reais } \\
\text { por quilo }\end{array}$ & $\begin{array}{c}\text { Intensidade da } \\
\text { Fiscalização }\end{array}$ & $\begin{array}{c}\text { Conhecimento } \\
\text { sobre a Marca }\end{array}$ \\
\hline $\mathbf{8 , 0 0}$ & Alta & Alto \\
\hline
\end{tabular}




\begin{tabular}{|c|c|c|}
\hline $\begin{array}{c}\text { Preço em Reais } \\
\text { por quilo }\end{array}$ & $\begin{array}{c}\text { Intensidade da } \\
\text { Fiscalização }\end{array}$ & $\begin{array}{c}\text { Conhecimento } \\
\text { sobre a Marca }\end{array}$ \\
\hline 16,00 & Baixa & Baixo \\
\hline
\end{tabular}

\begin{tabular}{|c|c|c|}
$\begin{array}{c}\text { Preço em Reais } \\
\text { por quilo }\end{array}$ & $\begin{array}{c}\text { Intensidade da } \\
\text { Fiscalização }\end{array}$ & $\begin{array}{c}\text { Conhecimento } \\
\text { sobre a Marca }\end{array}$ \\
\hline 12,00 & Alta & Baixo \\
\hline
\end{tabular}

\begin{tabular}{|c|c|c|}
$\begin{array}{c}\text { Preço em Reais } \\
\text { por quilo }\end{array}$ & $\begin{array}{c}\text { Intensidade da } \\
\text { Fiscalização }\end{array}$ & $\begin{array}{c}\text { Conhecimento } \\
\text { sobre a Marca }\end{array}$ \\
\hline 16,00 & Média & Alto \\
\hline
\end{tabular}

\begin{tabular}{|c|c|c|}
$\begin{array}{c}\text { Preço em Reais } \\
\text { por quilo }\end{array}$ & $\begin{array}{c}\text { Intensidade da } \\
\text { Fiscalização }\end{array}$ & $\begin{array}{c}\text { Conhecimento } \\
\text { sobre a Marca }\end{array}$ \\
\hline 12,00 & Baixa & Alto \\
\hline
\end{tabular}

\begin{tabular}{|c|c|c|}
$\begin{array}{c}\text { Preço em Reais } \\
\text { por quilo }\end{array}$ & $\begin{array}{c}\text { Intensidade da } \\
\text { Fiscalização }\end{array}$ & $\begin{array}{c}\text { Conhecimento } \\
\text { sobre a Marca }\end{array}$ \\
\hline $\mathbf{8 , 0 0}$ & Média & Baixo \\
\hline
\end{tabular}




\section{J - Caracterização do entrevistado}

\begin{tabular}{|c|c|c|c|}
\hline Característica & Opção & Freqüência & Porcentagem \\
\hline \multirow[t]{2}{*}{ Sexo } & Masculino & 178 & 30,1 \\
\hline & Feminino & 413 & 69,9 \\
\hline \multirow[t]{3}{*}{ Estado Civl } & Solteiro(a) & 88 & 14,9 \\
\hline & Casado(a) & 404 & 68,4 \\
\hline & Outra situação & 99 & 16,8 \\
\hline \multirow[t]{2}{*}{ Se trabalha } & Sim & 274 & 46,4 \\
\hline & Não & 316 & 53,5 \\
\hline \multirow[t]{5}{*}{ Idade } & Até 20 anos & 14 & 2,4 \\
\hline & 21 a 30 anos & 81 & 13,7 \\
\hline & 31 a 40 anos & 120 & 20,3 \\
\hline & 41 a 50 anos & 136 & 23,0 \\
\hline & Mais que 50 anos & 240 & 40,6 \\
\hline \multirow[t]{5}{*}{ Grau de Instrução } & $\begin{array}{l}\text { Analfabeto ou primário } \\
\text { incompleto }\end{array}$ & 124 & 21,0 \\
\hline & $\begin{array}{l}\text { Primário completo ou } \\
\text { ginásio incompleto }\end{array}$ & 161 & 27,2 \\
\hline & $\begin{array}{l}\text { Ginásio completo ou } \\
\text { colegial incompleto }\end{array}$ & 100 & 16,9 \\
\hline & $\begin{array}{l}\text { Colegial completo ou } \\
\text { superior incompleto }\end{array}$ & 139 & 23,5 \\
\hline & Superior completo & 67 & 11,3 \\
\hline \multirow{5}{*}{$\begin{array}{l}\text { Número de } \\
\text { pessoas com } \\
\text { quem reside }\end{array}$} & Uma pessoa & 26 & 4,4 \\
\hline & Duas pessoas & 125 & 21,2 \\
\hline & Três pessoas & 144 & 24,4 \\
\hline & Quatro pessoas & 153 & 25,9 \\
\hline & $\begin{array}{l}\text { Cinco pessoas ou } \\
\text { mais }\end{array}$ & 143 & 24,2 \\
\hline \multirow[t]{7}{*}{ Renda familiar } & Até $\mathrm{R} \$ 500,00$ & 110 & 18,6 \\
\hline & $\begin{array}{l}\text { De } R \$ 501,00 \text { a } R \$ \\
1.000,00\end{array}$ & 171 & 28,9 \\
\hline & $\begin{array}{l}\text { De } R \$ 1.001,00 \text { a } R \$ \\
1.500,00\end{array}$ & 138 & 23,4 \\
\hline & $\begin{array}{l}\text { De } R \$ 1.501,00 \text { a } R \$ \\
2.000,00\end{array}$ & 67 & 11,3 \\
\hline & $\begin{array}{l}\text { De } R \$ 2.001,00 \text { a } R \$ \\
2.500,00\end{array}$ & 44 & 7,4 \\
\hline & $\begin{array}{l}\text { De } R \$ 2.501,00 \text { a } R \$ \\
3.000,00\end{array}$ & 16 & 2,7 \\
\hline & Mais de $\mathrm{R} \$ 3.000,00$ & 45 & 7,6 \\
\hline \multirow{2}{*}{$\begin{array}{l}\text { Propriedade do } \\
\text { imóvel onde } \\
\text { reside }\end{array}$} & Alugado & 139 & 23,5 \\
\hline & Próprio & 452 & 76.5 \\
\hline \multirow{2}{*}{$\begin{array}{l}\text { Se possui } \\
\text { computador na } \\
\text { residência }\end{array}$} & Não & 280 & 47,4 \\
\hline & Sim & 311 & 52,6 \\
\hline \multirow{3}{*}{$\begin{array}{l}\text { Número de } \\
\text { automóveis que } \\
\text { possui }\end{array}$} & Nenhum & 230 & 38,9 \\
\hline & Um & 276 & 46,7 \\
\hline & Dois ou mais & 85 & 14,4 \\
\hline
\end{tabular}


K - Comportamento do entrevistado em relação ao consumo de carne.

\begin{tabular}{|c|c|c|c|c|}
\hline Comportamento & \multicolumn{2}{|c|}{ Opção } & Freqüência & Porcentagem \\
\hline \multirow{3}{*}{$\begin{array}{l}\text { Estabelecimento onde } \\
\text { compra carne }\end{array}$} & \multicolumn{2}{|c|}{ Açougue } & 153 & 25,9 \\
\hline & \multicolumn{2}{|l|}{ Supermercado } & 290 & 49,1 \\
\hline & \multicolumn{2}{|l|}{ Ambos } & 148 & 25,0 \\
\hline \multirow{2}{*}{$\begin{array}{l}\text { Se compra em um } \\
\text { único estabelecimento }\end{array}$} & \multicolumn{2}{|l|}{ Sim } & 311 & 52,6 \\
\hline & \multicolumn{2}{|l|}{ Não } & 280 & 47,4 \\
\hline \multirow{4}{*}{$\begin{array}{l}\text { Número de dias na } \\
\text { semana em que } \\
\text { consome carne bovina }\end{array}$} & \multicolumn{2}{|l|}{ Um } & 65 & 11,0 \\
\hline & \multicolumn{2}{|l|}{ Dois } & 137 & 23,2 \\
\hline & \multicolumn{2}{|l|}{ Três } & 155 & 26,2 \\
\hline & \multicolumn{2}{|l|}{ Quatro ou mais } & 233 & 39,6 \\
\hline \multirow{11}{*}{$\begin{array}{l}\text { Motivos que levam a } \\
\text { escolher o } \\
\text { estabelecimento em } \\
\text { que compra a carne }\end{array}$} & \multirow{2}{*}{ Proximidade } & Sim & 205 & 34,7 \\
\hline & & Não & 386 & 65,3 \\
\hline & \multirow{2}{*}{$\begin{array}{l}\text { Confiança no } \\
\text { estabelecimento }\end{array}$} & Sim & 190 & 32,1 \\
\hline & & Não & 401 & 67,9 \\
\hline & \multirow{2}{*}{$\begin{array}{l}\text { Intensidade da } \\
\text { fiscalização }\end{array}$} & Sim & 23 & 3,9 \\
\hline & & Não & 568 & 96,1 \\
\hline & \multirow{2}{*}{$\begin{array}{l}\text { Qualidade da } \\
\text { carne }\end{array}$} & Sim & 199 & 33,7 \\
\hline & & Não & 392 & 66,3 \\
\hline & \multirow{2}{*}{ Preço baixo } & Sim & 190 & 32,1 \\
\hline & & Não & 401 & 67,9 \\
\hline & \multicolumn{2}{|l|}{ Outro } & 37 & 6,3 \\
\hline \multirow{8}{*}{ Conhecimento sobre: } & \multirow{2}{*}{$\begin{array}{l}\text { O Serviço de } \\
\text { Inspeção } \\
\text { Federal }\end{array}$} & Conhece & 347 & 58,7 \\
\hline & & $\begin{array}{l}\text { Não } \\
\text { conhece }\end{array}$ & 244 & 41,3 \\
\hline & \multirow{2}{*}{$\begin{array}{l}\text { As substâncias } \\
\text { utilizadas na } \\
\text { produção da } \\
\text { carne }\end{array}$} & Conhece & 320 & 54,1 \\
\hline & & $\begin{array}{l}\text { Não } \\
\text { conhece }\end{array}$ & 271 & 45,9 \\
\hline & As possíveis & Conhece & 397 & 32,6 \\
\hline & $\begin{array}{l}\text { provocadas pela } \\
\text { ingestão de } \\
\text { carne } \\
\text { contaminada }\end{array}$ & $\begin{array}{l}\text { Não } \\
\text { conhece }\end{array}$ & 194 & 67,2 \\
\hline & O papel da & Conhece & 437 & 73,9 \\
\hline & $\begin{array}{l}\text { vigilância } \\
\text { sanitária }\end{array}$ & $\begin{array}{l}\text { Não } \\
\text { conhece }\end{array}$ & 154 & 26,1 \\
\hline & 1 cal do comnra & Sim & 331 & 56,0 \\
\hline & Local de compra & Não & 260 & 44,0 \\
\hline & Carne com & Sim & 90 & 15,2 \\
\hline & embalagem & Não & 501 & 84,8 \\
\hline & Fiscalização & Sim & 435 & 73,6 \\
\hline & intensiva & Não & 156 & 26,4 \\
\hline & Marca do & Sim & 93 & 15,7 \\
\hline & $\begin{array}{l}\text { produtor de } \\
\text { carne }\end{array}$ & Não & 496 & 84,3 \\
\hline Se o item contribui para & Legislação & Sim & 174 & 29,4 \\
\hline $\begin{array}{l}\text { uma maior percepção } \\
\text { da qualidade do produto }\end{array}$ & rigorosa & Não & 417 & 70,6 \\
\hline & & Sim & 126 & 21,7 \\
\hline & $\begin{array}{l}\text { açougue ou } \\
\text { supermercado }\end{array}$ & Não & 463 & 78,3 \\
\hline & Preco alto & Sim & 42 & 7,1 \\
\hline & & Não & 549 & 92,9 \\
\hline & Certificado ou & Sim & 277 & 46,9 \\
\hline & selo & Não & 314 & 53,1 \\
\hline & Educação e & Sim & 222 & 37,6 \\
\hline & $\begin{array}{l}\text { conhecimento } \\
\text { do consumidor }\end{array}$ & Não & 369 & 62.4 \\
\hline
\end{tabular}




\section{L - Sintaxe utilizada no SAS e STATA para a análise do modelo.}

\begin{tabular}{|c|c|}
\hline Software SAS - Análise Ordered Probit & Software STATA - Regressão Poisson \\
\hline $\begin{array}{l}\text { data marfis; } \\
\text { infile "c:/tmafi.prn"; } \\
\text { input Quest Rank MmFm MmFa MmFb MaFa } \\
\text { MbFb MbFa MaFm MaFb MbFm Pb Pm Pa; } \\
\text { if n_<=5319 then p=0; } \\
\text { if pb=1 then p=8; } \\
\text { if pm=1 then p=12; } \\
\text { if pa=1 then p=16; } \\
\text { rank2=10-rank; } \\
\text { p2=p*p; } \\
\text { proc logistic descending; } \\
\text { model rank2=MmFm MmFa MmFb MaFa MbFb } \\
\text { MbFa MaFm MaFb MbFm p p2/noint; } \\
\text { output out=saida1 p=pr1 l=L u=U } \\
\text { stdxbeta=desv1 xbeta=est1 } \\
\text { predprobs=i; } \\
\text { test mmfb-mbfb=mmfm-mbfb; } \\
\text { test mbfm-mbfb=mmfm-mbfb; } \\
\text { test mafm-mmfm=mafa-mmfm; } \\
\text { test mmfa-mmfm=mafa-mmfm; } \\
\text { test mmfm-mbfb=mafa-mmfm; } \\
\text { run; }\end{array}$ & 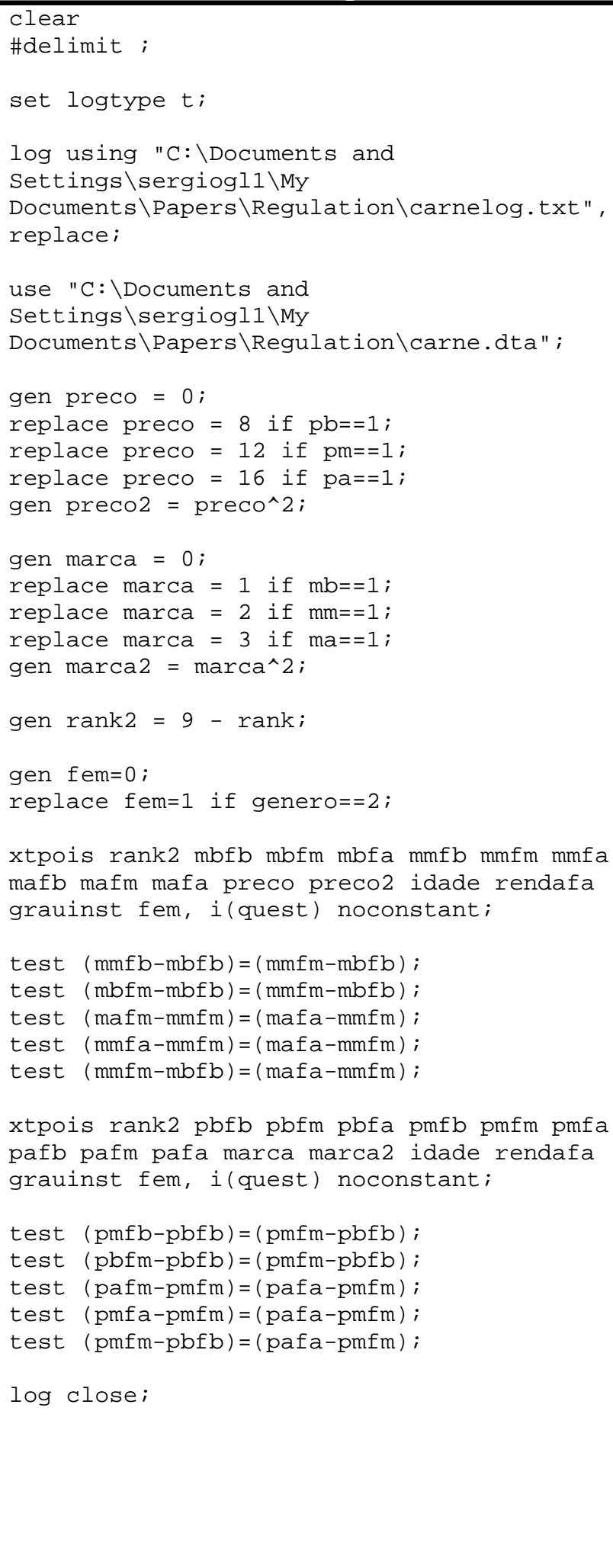 \\
\hline
\end{tabular}




\section{M - Resultados da análise entre marca e fiscalização}

a. Resultado da análise poisson e ordered probit entre marca e fiscalização

\begin{tabular}{|c|c|c|c|c|c|}
\hline Variável & Descrição & \multicolumn{2}{|c|}{ Poisson } & \multicolumn{2}{|c|}{ Ordered Probit } \\
\hline & & Coeficiente & $p>|z|$ & Coeficiente & $\mathrm{Pr}>\mathrm{Chi}^{2}$ \\
\hline Intercepto 2 & & & & 1,00 & 0,00 \\
\hline Intercepto 3 & & & & 1,68 & 0,00 \\
\hline Intercepto 4 & & & & 2,27 & 0,00 \\
\hline Intercepto 5 & & & & 2,88 & 0,00 \\
\hline Intercepto 6 & & & & 3,55 & 0,00 \\
\hline Intercepto 7 & & & & 4,38 & 0,00 \\
\hline Intercepto 8 & & & & 5,76 & 0,00 \\
\hline $\mathrm{MbFb}$ & Sem marca e sem fiscalização & $\beta_{1}=-0,65$ & 0,85 & $\beta_{1}^{\prime}=-7,72$ & 0,04 \\
\hline $\mathrm{MbFm}$ & Sem marca e fiscalização regular & $\beta_{2}=1,42$ & 0,00 & $\beta_{2}^{\prime}=-4,27$ & 0,24 \\
\hline $\mathrm{MbFa}$ & Sem marca e fiscalização intensiva & $\beta_{3}=1,89$ & 0,00 & $\beta_{3}^{\prime}=-2,93$ & 0,47 \\
\hline $\mathrm{MmFb}$ & Marca desconhecida e sem fiscalização & $\beta_{4}=1,15$ & 0,00 & $\beta_{4}^{\prime}=-4,98$ & 0,17 \\
\hline $\mathrm{MmFm}$ & Marca desconhecida e fiscalização regular & $\beta_{5}=1,86$ & 0,00 & $\beta_{5}^{\prime}=-3,15$ & 0,44 \\
\hline $\mathrm{MmFa}$ & Marca desconhecida e fiscalização intensiva & $\beta_{6}=1,88$ & 0,00 & $\beta_{6}^{\prime}=-2,88$ & 0,30 \\
\hline $\mathrm{MaFb}$ & Marca conhecida e sem fiscalização & $\beta_{7}=1,53$ & 0,00 & $\beta_{7}^{\prime}=-4,23$ & 0,73 \\
\hline $\mathrm{MaFm}$ & Marca conhecida e fiscalização regular & $\beta_{8}=1,73$ & 0,00 & $\beta_{8}^{\prime}=-3,43$ & 0,80 \\
\hline $\mathrm{MaFa}$ & Marca conhecida e fiscalização intensiva & $\beta_{9}=2,09$ & 0,00 & $\beta_{9}^{\prime}=-1,26$ & 0,83 \\
\hline Preço & Preço do produto & $\beta_{\text {preço }}=-0,05$ & 0,43 & $\beta_{\text {preço }}=0,17$ & 0,80 \\
\hline$(\text { Preço })^{2}$ & Preço do produto ao quadrado & $\beta_{\text {preço2 }}=0,00$ & 0,45 & $\beta_{\text {preço2 }}=-0,01$ & 0,83 \\
\hline Idade & Idade do entrevistado & $\beta_{\text {idade }}=-0,00$ & 0,94 & & \\
\hline Renda Familiar & Renda familiar do entrevistado & $\beta_{\text {renda }}=-0,00$ & 0,95 & & \\
\hline $\begin{array}{l}\text { Grau de } \\
\text { Instrução }\end{array}$ & Grau de instrução do entrevistado & $\beta_{\text {instrução }}=0,00$ & 0,92 & & \\
\hline Sexo & Sexo do entrevistado & $\beta_{\text {sexo }}=0,00$ & 0,98 & & \\
\hline
\end{tabular}

b. Teste das hipóteses de complementaridade entre marca e fiscalização

\begin{tabular}{|c|c|c|c|c|c|}
\hline Teste & Descrição do teste & Conclusão & Nível & $\begin{array}{l}\text { Poisson: } \\
\text { Prob. > } \mathrm{Chi}^{2}\end{array}$ & $\begin{array}{l}\text { Ordered } \\
\text { probit: } \\
\text { Prob. }>\mathrm{Chi}^{2} \\
\end{array}$ \\
\hline $\begin{array}{c}\left(\beta_{1}-\beta_{5}\right)>\left(\beta_{3}-\beta_{5}\right) \\
\text { Hipótese A }\end{array}$ & $\begin{array}{c}\text { Um aumento conjunto da intensidade da } \\
\text { marca e da fiscalização proporciona maior } \\
\text { percepção de qualidade do que um aumento } \\
\text { isolado da marca }\end{array}$ & $\begin{array}{l}\text { Fiscalização } \\
\text { complementa a } \\
\text { marca }\end{array}$ & $\begin{array}{l}\text { Baixo } \\
\text { para } \\
\text { médio }\end{array}$ & 0,0000 & 0,0007 \\
\hline $\begin{array}{c}\left(\beta_{1}-\beta_{5}\right)>\left(\beta_{9}-\beta_{5}\right) \\
\text { Hipótese A }\end{array}$ & $\begin{array}{l}\text { Um aumento conjunto da intensidade da } \\
\text { marca e da fiscalização proporciona maior } \\
\text { percepção de qualidade do que um aumento } \\
\text { isolado da fiscalização }\end{array}$ & $\begin{array}{l}\text { Marca } \\
\text { complementa a } \\
\text { fiscalização }\end{array}$ & $\begin{array}{l}\text { Baixo } \\
\text { para } \\
\text { médio }\end{array}$ & 0,0000 & 0,0378 \\
\hline $\begin{array}{c}\left(\beta_{4}-\beta_{1}\right)>\left(\beta_{7}-\beta_{1}\right) \\
\text { Hipótese B }\end{array}$ & $\begin{array}{c}\text { Um aumento conjunto da intensidade da } \\
\text { marca e da fiscalização proporciona maior } \\
\text { percepção de qualidade do que um aumento } \\
\text { isolado da marca }\end{array}$ & $\begin{array}{l}\text { Fiscalização } \\
\text { complementa a } \\
\text { marca }\end{array}$ & $\begin{array}{l}\text { Médio } \\
\text { para } \\
\text { alto }\end{array}$ & 0,0098 & 0,0000 \\
\hline $\begin{array}{c}\left(\beta_{4}-\beta_{1}\right)>\left(\beta_{2}-\beta_{1}\right) \\
\text { Hipótese B }\end{array}$ & $\begin{array}{l}\text { Um aumento conjunto da intensidade da } \\
\text { marca e da fiscalização proporciona maior } \\
\text { percepção de qualidade do que um aumento } \\
\text { exclusivo da fiscalização }\end{array}$ & $\begin{array}{l}\text { Marca } \\
\text { complementa a } \\
\text { fiscalização }\end{array}$ & $\begin{array}{l}\text { Médio } \\
\text { para } \\
\text { alto }\end{array}$ & 0,1223 & 0,0021 \\
\hline $\begin{array}{c}\left(\beta_{1}-\beta_{5}\right)>\left(\beta_{4}-\beta_{1}\right) \\
\text { Hipótese C }\end{array}$ & $\begin{array}{l}\text { O aumento da percepção de qualidade é } \\
\text { menor a um nível alto de intensidade de } \\
\text { marca e fiscalização }\end{array}$ & $\begin{array}{l}\text { O incremento da } \\
\text { percepção de } \\
\text { qualidade é } \\
\text { maior ao nível } \\
\text { baixo a médio } \\
\text { do que ao nível } \\
\text { médio a alto }\end{array}$ & $\begin{array}{l}\text { Baixo } \\
\text { para } \\
\text { médio e } \\
\text { médio } \\
\text { para } \\
\text { alto }\end{array}$ & 0,0000 & 0,0031 \\
\hline
\end{tabular}




\section{N - Resultados da análise entre preço e fiscalização}

a. Resultado da análise Poisson e Ordered Probit entre preço e fiscalização

\begin{tabular}{|c|c|c|c|c|c|}
\hline \multirow[t]{2}{*}{ Variável } & \multirow[t]{2}{*}{ Descrição } & \multicolumn{2}{|c|}{ Poisson } & \multicolumn{2}{|c|}{ Ordered Probit } \\
\hline & & Coeficiente & $p>|z|$ & Coeficiente & $\mathrm{Pr}>\mathrm{Chi}^{2}$ \\
\hline Intercepto 2 & & & & 1,00 & 0,00 \\
\hline Intercepto 3 & & & & 1,68 & 0,00 \\
\hline Intercepto 4 & & & & 2,27 & 0,00 \\
\hline Intercepto 5 & & & & 2,88 & 0,00 \\
\hline Intercepto 6 & & & & 3,55 & 0,00 \\
\hline Intercepto 7 & & & & 4,38 & 0,00 \\
\hline Intercepto 8 & & & & 5,76 & 0,00 \\
\hline $\mathrm{PbFb}$ & Preço baixo e sem fiscalização & $\beta_{1}=0,30$ & 0,47 & $\beta_{1}^{\prime}=-5,19$ & 0,02 \\
\hline $\mathrm{PbFm}$ & Preço baixo e fiscalização regular & $\beta_{2}=0,76$ & 0,01 & $\beta_{2}^{\prime}=-4,02$ & 0,04 \\
\hline $\mathrm{PbFa}$ & Preço baixo e fiscalização intensiva & $\beta_{3}=1,23$ & 0,00 & $\beta_{3}^{\prime}=-1,66$ & 0,00 \\
\hline $\mathrm{PmFb}$ & Preço médio e sem fiscalização & $\beta_{4}=0,64$ & 0,06 & $\beta_{4}^{\prime}=-4,42$ & 0,15 \\
\hline PmFm & Preço médio e fiscalização regular & $\beta_{5}=0,98$ & 0,02 & $\beta_{5}^{\prime}=-3,17$ & 0,00 \\
\hline $\mathrm{PmFa}$ & Preço médio e fiscalização intensiva & $\beta_{6}=1,22$ & 0,00 & $\beta_{6}^{\prime}=-2,48$ & 0,02 \\
\hline $\mathrm{PaFb}$ & Preço alto e sem fiscalização & $\beta_{7}=-0,69$ & 0,02 & $\beta_{7}^{\prime}=-7,26$ & 0,00 \\
\hline $\mathrm{PaFm}$ & Preço alto e fiscalização regular & $\beta_{8}=0,89$ & 0,01 & $\beta_{8}^{\prime}=-3,61$ & 0,00 \\
\hline $\mathrm{PaFa}$ & Preço alto e fiscalização intensiva & $\beta_{9}=1,04$ & 0,01 & $\beta_{9}^{\prime}=-2,87$ & 0,00 \\
\hline Marca & Preço do produto & $\beta_{\text {marca }}=0,50$ & 0,21 & $\beta_{\text {marca }}=-0,87$ & 0,53 \\
\hline$(\text { Marca })^{2}$ & Preço do produto ao quadrado & $\beta_{\text {marca2 }}=-0,10$ & 0,32 & $\beta_{\text {marca2 }}=-0,14$ & 0,69 \\
\hline Idade & Idade do entrevistado & $\beta_{\text {idade }}=0,00$ & 0,95 & & \\
\hline Renda Familiar & Renda familiar do entrevistado & $\beta_{\text {renda }}=-0,00$ & 0,96 & & \\
\hline $\begin{array}{l}\text { Grau de } \\
\text { Instrução }\end{array}$ & Grau de instrução do entrevistado & $\beta_{\text {instrução }}=0,00$ & 0,94 & & \\
\hline Sexo & Sexo do entrevistado & $\beta_{\text {sexo }}=-0,00$ & 0,98 & & \\
\hline
\end{tabular}

b. Teste das hipóteses de complementaridade entre preço e fiscalização

\begin{tabular}{|c|c|c|c|c|c|}
\hline Teste & Descrição do teste & Conclusão & Nível & $\begin{array}{l}\text { Poisson: } \\
\text { Prob. > Chi }\end{array}$ & $\begin{array}{l}\text { Ordered } \\
\text { probit: } \\
\text { Prob. }>\mathrm{Chi}^{2}\end{array}$ \\
\hline $\begin{array}{c}\left(\beta_{1}-\beta_{5}\right)>\left(\beta_{3}-\beta_{5}\right) \\
\text { Hipótese D }\end{array}$ & $\begin{array}{l}\text { Um aumento conjunto do preço e da } \\
\text { fiscalização proporciona maior percepção de } \\
\text { qualidade do que um aumento isolado do } \\
\text { preço }\end{array}$ & $\begin{array}{l}\text { Fiscalização } \\
\text { complementa o } \\
\text { preço }\end{array}$ & $\begin{array}{l}\text { Baixo } \\
\text { para } \\
\text { médio }\end{array}$ & 0,0029 & 0,0035 \\
\hline $\begin{array}{l}\left(\beta_{1}-\beta_{5}\right)>\left(\beta_{9}-\beta_{5}\right) \\
\quad \text { Hipótese D }\end{array}$ & $\begin{array}{l}\text { Um aumento conjunto do preço e da } \\
\text { fiscalização proporciona maior percepção de } \\
\text { qualidade do que um aumento isolado da } \\
\text { fiscalização }\end{array}$ & $\begin{array}{c}\text { Preço } \\
\text { complementa a } \\
\text { fiscalização }\end{array}$ & $\begin{array}{l}\text { Baixo } \\
\text { para } \\
\text { médio }\end{array}$ & 0,0567 & 0,0303 \\
\hline $\begin{array}{c}\left(\beta_{4}-\beta_{1}\right)>\left(\beta_{7}-\beta_{1}\right) \\
\text { Hipótese E }\end{array}$ & $\begin{array}{l}\text { Um aumento conjunto do preço e da } \\
\text { fiscalização proporciona maior percepção de } \\
\text { qualidade do que um aumento isolado do } \\
\text { preço }\end{array}$ & $\begin{array}{l}\text { Fiscalização } \\
\text { não } \\
\text { complementa o } \\
\text { preço } \\
\end{array}$ & $\begin{array}{l}\text { Médio } \\
\text { para } \\
\text { alto }\end{array}$ & $0,1797^{*}$ & $0,0864^{*}$ \\
\hline $\begin{array}{c}\left(\beta_{4}-\beta_{1}\right)>\left(\beta_{2}-\beta_{1}\right) \\
\text { Hipótese } E\end{array}$ & $\begin{array}{l}\text { Um aumento conjunto do preço e da } \\
\text { fiscalização proporciona maior percepção de } \\
\text { qualidade do que um aumento isolado da } \\
\text { fiscalização }\end{array}$ & $\begin{array}{c}\text { Preço não } \\
\text { complementa a } \\
\text { fiscalização }\end{array}$ & $\begin{array}{l}\text { Médio } \\
\text { para } \\
\text { alto }\end{array}$ & $0,1243^{*}$ & $0,3210^{*}$ \\
\hline $\begin{array}{c}\left(\beta_{1}-\beta_{5}\right)>\left(\beta_{4}-\beta_{1}\right) \\
\text { Hipótese F }\end{array}$ & $\begin{array}{l}\text { O aumento da percepção de qualidade é } \\
\text { menor a um nível alto de preço e fiscalização }\end{array}$ & $\begin{array}{l}\text { O incremento da } \\
\text { percepção de } \\
\text { qualidade é } \\
\text { maior ao nível } \\
\text { baixo a médio } \\
\text { do que ao nível } \\
\text { médio a alto }\end{array}$ & $\begin{array}{l}\text { Baixo } \\
\text { para } \\
\text { médio e } \\
\text { médio } \\
\text { para } \\
\text { alto }\end{array}$ & 0,0000 & 0,0000 \\
\hline
\end{tabular}




\section{O - Respostas dos agentes privados às questões fechadas}

\begin{tabular}{|c|c|c|c|}
\hline Resposta & Opção & Freqüência & Porcentagem \\
\hline \multirow{2}{*}{$\begin{array}{l}\text { Local de realização } \\
\text { da pesquisa }\end{array}$} & Supermercado & 15 & 34,1 \\
\hline & Açougue & 29 & 65,9 \\
\hline \multirow{2}{*}{$\begin{array}{l}\text { Se o consumidor se } \\
\text { preocupa com a } \\
\text { qualidade da carne }\end{array}$} & Sim & 40 & 90,9 \\
\hline & Não & 4 & 9,1 \\
\hline \multirow{2}{*}{$\begin{array}{l}\text { Se o consumidor } \\
\text { pagaria mais por uma } \\
\text { carne de melhor } \\
\text { qualidade }\end{array}$} & Sim & 33 & 75,0 \\
\hline & Não & 11 & 25,0 \\
\hline \multirow{2}{*}{$\begin{array}{l}\text { Se o estabelecimento } \\
\text { estaria disposto a } \\
\text { investir em marca } \\
\text { própria }\end{array}$} & Sim & 21 & 47,7 \\
\hline & Não & 23 & 52,3 \\
\hline \multirow{2}{*}{$\begin{array}{l}\text { Se o estabelecimento } \\
\text { investiria em } \\
\text { propaganda para } \\
\text { evidenciar a } \\
\text { qualidade da sua } \\
\text { carne }\end{array}$} & Sim & 32 & 72,7 \\
\hline & Não & 12 & 27,3 \\
\hline \multirow{3}{*}{$\begin{array}{l}\text { Qual é o nível de rigor } \\
\text { da legislação nacional } \\
\text { relacionada à garantia } \\
\text { da qualidade da carne }\end{array}$} & Alto & 23 & 52,3 \\
\hline & Médio & 12 & 27,3 \\
\hline & Baixo & 9 & 20,5 \\
\hline \multirow{3}{*}{$\begin{array}{l}\text { Qual é o grau de } \\
\text { eficiência da } \\
\text { fiscalização da } \\
\text { vigilância sanitária }\end{array}$} & Alto & 18 & 40,9 \\
\hline & Médio & 20 & 45,5 \\
\hline & Baixo & 6 & 13,6 \\
\hline
\end{tabular}




\section{P - Ações privadas e públicas sugeridas pelos estabelecimentos}

\begin{tabular}{|c|c|c|}
\hline No. & Ações dos Estabelecimentos & Ações do Governo \\
\hline 1 & Boca a boca, uma divulgação & Maior fiscalização por parte do governo \\
\hline 2 & $\begin{array}{l}\text { O povo deveria ser mais exigente quanto à } \\
\text { qualidade da carne }\end{array}$ & $\begin{array}{l}\text { Já desenvolveu, ao obrigar os frigoríficos a } \\
\text { desossarem as carnes para vender nos } \\
\text { açougues }\end{array}$ \\
\hline 3 & $\begin{array}{l}\text { Uma escolha melhor da compra de carne do } \\
\text { frigorífico }\end{array}$ & $\begin{array}{l}\text { O governo poderia ajudar diminuindo os juros, } \\
\text { incentivando o investimento dos açougues em } \\
\text { relação a qualidade }\end{array}$ \\
\hline 4 & $\begin{array}{l}\text { Comodidade, respeito, agilidade, atendimento, } \\
\text { qualidade na compra da carne e nos } \\
\text { equipamentos, limpeza(loja e produção), } \\
\text { preocupação com clientes e funcionários }\end{array}$ & $\begin{array}{l}\text { Fiscalização e desosso da carne (em certo } \\
\text { ponto já é feito) }\end{array}$ \\
\hline 5 & Variedade, qualidade da carne (temperatura) & Transporte adequado da carne \\
\hline \multirow[t]{2}{*}{6} & Marca da carne & Baixar preço \\
\hline & $\begin{array}{l}\text { Carimbo do SIF; só caminhão do Frigorífico } \\
\text { descarrega carnes em frente do açougue; } \\
\text { uniformes (avental); toda carne vem com carimbo } \\
\text { e a marca do frigorífico; conversa com os clientes } \\
\text { para explicar a importância de se comprar a carne } \\
\text { com o selo do SIF }\end{array}$ & $\begin{array}{l}\text { Divulgar, propaganda, educar, mostrar o que é } \\
\text { o SIF. }\end{array}$ \\
\hline 8 & 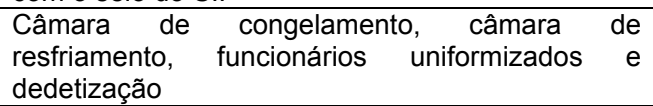 & $\begin{array}{l}\text { Diminuir os impostos para criar condições para } \\
\text { investir em qualidade }\end{array}$ \\
\hline 9 & $\begin{array}{l}\text { Carnes embaladas a vácuo; já recebem a carne } \\
\text { limpa, e se preciso é preparada aqui. Higiene, } \\
\text { uniforme com luvas. Toda carne contém o selo do } \\
\text { SIF. }\end{array}$ & $\begin{array}{l}\text { Falta conhecimento, reestruturação do } \\
\text { conhecimento com propagandas nas escolas. } \\
\text { Incentivo aos clientes para pedirem notas e } \\
\text { verificar a procedência }\end{array}$ \\
\hline 10 & $\begin{array}{l}\text { Carne fresca; quando a carne se torna escura é } \\
\text { retirada; utiliza-se o Kit completo de higiene, e o } \\
\text { tempo de permanência da carne no freezer é } \\
\text { pequeno }\end{array}$ & $\begin{array}{l}\text { Embalagens; desossadas; - legislação - tudo } \\
\text { separado em partes. }\end{array}$ \\
\hline 11 & $\begin{array}{l}\text { Educando e mostrando a qualidade, investindo em } \\
\text { lojas de grande porte para atrair clientes. }\end{array}$ & $\begin{array}{l}\text { Propaganda. Precisava mostrar o que é } \\
\text { qualidade, pois o cliente desconhece e } \\
\text { geralmente procura apenas preço, e isto não é } \\
\text { sinônimo de qualidade. }\end{array}$ \\
\hline 12 & $\begin{array}{l}\text { Mostrar, explicar como a carne é exposta. Higiene, } \\
\text { retirar os excessos, carne limpa e bem exposta. }\end{array}$ & $\begin{array}{l}\text { Propagandas, comer carne com educação, a } \\
\text { mídia prejudica a venda de carne. }\end{array}$ \\
\hline 13 & $\begin{array}{l}\text { Carne de } 2^{a} \text { fica exposta no balcão, enquanto que } \\
\text { a de } 1^{a} \text { fica no freezer. Todos os dias é cortada } \\
\text { carne nova, e no dia seguinte, a que sobrou é } \\
\text { moída }\end{array}$ & Mais fiscalização, inclusive com os fiscais \\
\hline 14 & $\begin{array}{l}\text { O cliente pode ter mais segurança comprando } \\
\text { carnes preparadas nas bandejas e embaladas a } \\
\text { vácuo. }\end{array}$ & Fiscalização mais eficiente nos frigoríficos. \\
\hline 15 & $\begin{array}{l}\text { Preocupação com a origem da carne, frigorífico } \\
\text { vistoriado e garantia da qualidade da carne. }\end{array}$ & Fiscalização em todos os estabelecimentos. \\
\hline 16 & Selo de qualidade & Fiscalização. \\
\hline 17 & $\begin{array}{l}\text { Em relação à qualidade de nossos produtos } \\
\text { comercializados (carne), há um grande } \\
\text { desenvolvimento quanto a garantir uma carne de } \\
\text { alta qualidade para os nossos consumidores, são } \\
\text { elas: as revisões diárias de todas as bandejas de } \\
\text { carne, sendo avaliada a sua cor, aparência, odor e } \\
\text { temperatura, sempre dentro de sua vida útil. }\end{array}$ & $\begin{array}{l}\text { Uma melhor vigilância quanto a abatedouros e } \\
\text { frigoríficos clandestinos e uma melhor } \\
\text { vigilância sanitária, garantindo, assim, que os } \\
\text { consumidores possam pagar um preço justo } \\
\text { por uma carne saudável e de ótima qualidade. }\end{array}$ \\
\hline 18 & $\begin{array}{l}\text { A demonstração do produto na frente do } \\
\text { consumidor, dando uma boa aparência ao produto } \\
\text { quanto à higiene, etc. }\end{array}$ & $\begin{array}{l}\text { Quanto a isso, na minha opinião, ele já vem } \\
\text { desenvolvendo uma boa ação, quanto as } \\
\text { qualidades da carne, a refrigeração e os } \\
\text { transportes. }\end{array}$ \\
\hline 19 & $\begin{array}{l}\text { Explicar que a carne é de boa qualidade, que a } \\
\text { empresa se preocupa em comprar carne } \\
\text { fiscalizada. }\end{array}$ & Fiscalização. \\
\hline 20 & $\begin{array}{l}\text { Divulgação interna de nossos produtos, como por } \\
\text { exemplo degustação. Formação de funcionários. }\end{array}$ & $\begin{array}{l}\text { Maior credibilidade para a agroindústria } \\
\text { nacional e investimento para o pequeno e } \\
\text { médio produtor. }\end{array}$ \\
\hline 21 & $\begin{array}{l}\text { Recebimento de carne todos os dias; cortar a } \\
\text { carne na frente do consumidor. }\end{array}$ & Fiscalização. \\
\hline
\end{tabular}




\begin{tabular}{|c|c|c|}
\hline No. & Ações dos Estabelecimentos & Ações do Governo \\
\hline 22 & $\begin{array}{l}\text { Maneira de trabalho, uniforme, higiene no local, } \\
\text { apresentação dos produtos e do estabelecimento. }\end{array}$ & $\begin{array}{l}\text { Campanhas publicitárias para conscientizar a } \\
\text { população a comprar em estabelecimentos } \\
\text { regularizados. }\end{array}$ \\
\hline 23 & Aparência, higiene e atendimento. & $\begin{array}{l}\text { Ralação ao preço elevado (diminuição de } \\
\text { impostos) }\end{array}$ \\
\hline 24 & $\begin{array}{l}\begin{array}{l}\text { Apresentação da carne fresca, mantendo a } \\
\text { higiene. }\end{array} \\
\end{array}$ & Não é necessário tomar nenhuma ação. \\
\hline 25 & $\begin{array}{l}\text { Higiene, conscientização do supermercado ao } \\
\text { consumidor. }\end{array}$ & $\begin{array}{l}\text { Conscientizar, tomar medidas de campanhas } \\
\text { de conscientização. }\end{array}$ \\
\hline 26 & $\begin{array}{l}\text { Mostrar a higiene do açougue e conhecer a origem } \\
\text { da carne }\end{array}$ & $\begin{array}{l}\text { Através de campanhas que eduquem o } \\
\text { consumidor a comprar apenas em } \\
\text { estabelecimentos regularizados. } \\
\end{array}$ \\
\hline 27 & Atendimento & Campanha de conscientização \\
\hline 28 & Conscientização do cliente & Campanha de conscientização. \\
\hline 29 & $\begin{array}{l}\text { Manter a higiene do local, e a mercadoria fica } \\
\text { exposta. }\end{array}$ & $\begin{array}{l}\text { Uma campanha de conscientização mostrando } \\
\text { e ensinando o consumidor a comprar em } \\
\text { estabelecimentos regularizados e carnes com } \\
\text { o selo do SIF. }\end{array}$ \\
\hline 30 & Tendo uma boa refrigeração & $\begin{array}{l}\text { Educar o povo a estar conhecendo a origem da } \\
\text { carne que consome. }\end{array}$ \\
\hline 31 & $\begin{array}{l}\text { Comprar carnes a cada } 02 \text { dias, para que a } \\
\text { aparência esteja boa. O animal tem que ser } \\
\text { macho, com partes traseiras grandes ( carne mais } \\
\text { macia). }\end{array}$ & $\begin{array}{l}\text { A carne já deveria ser embalada, mas com um } \\
\text { custo não muito caro, ou seja, o governo } \\
\text { deveria começar a exigir tais medidas dos } \\
\text { fornecedores do produto. }\end{array}$ \\
\hline 32 & $\begin{array}{l}\text { Pegar carne todos os dias para ter sempre carne } \\
\text { fresca. Investir em higiene do local. }\end{array}$ & Continuar a fiscalização, que já é boa. \\
\hline 33 & $\begin{array}{l}\text { Passar para o consumidor a idéia de qualidade da } \\
\text { carne, falando para ele sobre a qualidade, ou seja, } \\
\text { para que perceba que o açougue investe em } \\
\text { qualidade. Propaganda no boca a boca. }\end{array}$ & $\begin{array}{l}\text { Divulgar mais dentro do país a qualidade da } \\
\text { carne brasileira. }\end{array}$ \\
\hline 34 & Bom atendimento & Campanha de conscientização \\
\hline 35 & $\begin{array}{l}\text { Poderia ter uma campanha séria, uma fiscalização } \\
\text { rigorosa, e mais honestidade da fiscalização, e } \\
\text { uma campanha geral para mudar a lei, que o povo } \\
\text { ajude a fiscalizar, cobrar, exigir seus direitos e que } \\
\text { a lei funcione. }\end{array}$ & $\begin{array}{l}\text { Fazer cumprir a lei, serem honestos, serem } \\
\text { patriotas, vestirem a camisa do Brasil. }\end{array}$ \\
\hline 36 & Investir na higiene e na qualidade do produto. & $\begin{array}{l}\text { Fazer campanhas de divulgação nos } \\
\text { frigoríficos, demonstrando a qualidade da } \\
\text { carne brasileira, pois o produto brasileiro é o } \\
\text { melhor do mundo. Falta divulgação. }\end{array}$ \\
\hline 37 & $\begin{array}{l}\text { Preocupação com uma boa exposição da carne } \\
\text { mantendo o máximo de higiene no balcão e } \\
\text { funcionários. }\end{array}$ & $\begin{array}{l}\text { Não tenho visto nenhum trabalho direcionado à } \\
\text { venda de carne com selo de qualidade ou } \\
\text { coisa parecida }\end{array}$ \\
\hline 38 & Carne fresca (todos os dias) & $\begin{array}{l}\text { Colocar número correto na carne para não } \\
\text { enganar o cliente (muitos mudam o corte) }\end{array}$ \\
\hline 39 & $\begin{array}{l}\text { Selo do Sif, distribuição de jornais evidenciando a } \\
\text { procedência da carne }\end{array}$ & Propaganda para conscientizar o povo \\
\hline 40 & $\begin{array}{l}\text { Variedade de produtos, limpeza adequada, carne } \\
\text { fresca }\end{array}$ & $\begin{array}{l}\text { Investir em propaganda de conscientização } \\
\text { popular }\end{array}$ \\
\hline 41 & $\begin{array}{l}\text { Vender sempre carne fresca e manter a higiene do } \\
\text { local. }\end{array}$ & $\begin{array}{llll}\text { Deveria realizar uma campanha } & \text { de } \\
\text { conscientização para a população. } & & \\
\end{array}$ \\
\hline 42 & $\begin{array}{l}\text { Higiene no local, tanto no manuseio com as } \\
\text { carnes, quanto na aparência da loja. }\end{array}$ & $\begin{array}{l}\text { Deveria desenvolver uma campanha de } \\
\text { conscientização, para que a população possa } \\
\text { escolher comprar apenas em açougues } \\
\text { regularizados. }\end{array}$ \\
\hline 43 & $\begin{array}{l}\text { Higiene do local. Aposta em preparados orgânicos } \\
\text { e químicos que combatem a proliferação de } \\
\text { microorganismos. Uniformização da equipe. } \\
\text { Climatização do salão. Produto fiscalizado. } \\
\text { Frigoríficos idôneos. }\end{array}$ & $\begin{array}{l}\text { Não existe. Poderia fazer uma campanha } \\
\text { educadora para que o consumidor aprenda a } \\
\text { boicotar produtos de procedência ignorada. }\end{array}$ \\
\hline 44 & $\begin{array}{l}\text { Recebe somente com o grau certo, caminhão } \\
\text { limpo, higienizado. A carne fica exposta durante } 3 \\
\text { dias, e após, é considerado quebra. Utiliza-se } \\
\text { touca, máscara e avental. É proibido usar jóias, e } \\
\text { pega-se a carne somente com luvas. Na câmara } \\
\text { os funcionários usam capas, botas e calças } \\
\text { térmicas. }\end{array}$ & $\begin{array}{l}\text { Propaganda para educar o povo como deve } \\
\text { ser o procedimento correto para se vender a } \\
\text { carne, desde o abatedouro até } \quad \\
\text { supermercado. }\end{array}$ \\
\hline
\end{tabular}




\section{APÊNDICE}

\section{A. Descrição do modelo hedônico}

A teoria neoclássica da demanda assume que um consumidor racional sempre escolherá uma configuração preferida de bens a partir de um conjunto de alternativas viáveis. Sendo $Y$ a renda disponível ao consumidor, e $P_{i}$ , os preços dos bens $X_{i}$, com $i=1, \ldots, n$, o consumidor escolherá, sujeito a restrição orçamentária, i. e., uma combinação de bens $X^{*}$ que maximizará a função utilidade $U$,

$$
\begin{array}{r}
\text { Maximizar } \mathrm{U}=\mathrm{U}\left(\mathrm{X}_{1}, \mathrm{X}_{2}, \ldots, \mathrm{X}_{\mathrm{n}}\right) \\
\text { Sujeito a } \sum_{i=1}^{n} \mathrm{P}_{\mathrm{i}} \mathrm{X}_{\mathrm{i}}=\mathrm{Y} \text { (1) }
\end{array}
$$

No modelo desenvolvido por Lancaster (op.cit, 1971), os bens não são objetos imediatos de sua preferência ou utilidade, mas têm associados a eles atributos diretamente relevantes para o consumidor. Nessa formulação, a função utilidade é função do conjunto de atributos ou características do produto $\left(c_{j}\right)$, obtidas através de uma série de produtos. O consumidor, com base nos atributos, maximizará:

$$
U=U\left(c_{1}, c_{2}, \ldots, c_{m}\right)(2)
$$

sujeito à tecnologia de consumo que transforma o produto em atributo, i.e.,

onde

$$
c_{j i}=a_{j i} X_{i} \quad i=1, \ldots, n \text { e } j=1, \ldots, m(3)
$$

e à restrição orçamentária:

$$
\mathrm{c}_{\mathrm{j}}=\sum_{\mathrm{i}=1}^{\mathrm{n}} \mathrm{c}_{\mathrm{ji}}
$$

onde:

$$
\sum_{i=1}^{n} \mathrm{P}_{\mathrm{i}} \mathrm{X}_{\mathrm{i}}=\mathrm{Y}
$$

$\mathrm{c}_{1}, \mathrm{c}_{2}, \ldots, \mathrm{c}_{\mathrm{m}}$ são os atributos ou as características dos bens;

$X_{i}$ é a quantidade do i-ésimo bem;

$a_{\mathrm{ji}}$ é a quantidade da j-ésima característica em uma unidade do bem i.

Um dos primeiros estudos de modelos em que o consumidor adquiria produtos com base nas características foi desenvolvido por Waught (1977) e o primeiro modelo econômico de características foi publicado independentemente por Theil (1952) e Houthakker (1952). Ladd e Zober (1982) estenderam o modelo de Lancaster, assumindo que os compradores consomem produtos, com base nos serviços que estes oferecem. A utilidade total fica sendo determinada pelo total de serviços providos durante o seu consumo. Ravenswaay e Hoehn (op. cit.) posteriormente reformularam o modelo focando sobre um único produto. Esse modelo será utilizado neste trabalho e a base teórica é descrita a seguir.

Considere um produto $x_{1}$ oferecido em um mercado a um preço $p_{1}$. Também nesse mercado, estão presentes outras opções de produtos que, no total, compõem um vetor de alternativas de produtos ${ }^{54} \mathbf{x}=\left(x_{2}, \ldots, x_{i}\right)$, oferecidos a um vetor de preços correspondente a $\mathbf{p}=\left(p_{2}, \ldots, p_{i}\right)$. Com isso o consumidor pode expressar sua preferência através da maximização da função utilidade que, por sua vez, está sujeita a sua renda como foi visto na equação (1). $O$ produto $x_{1}$ também contém um vetor de $J$ atributos de qualidade $a_{1}=\left(a_{11}, \ldots, a_{i j}\right)$ e o somatório dos produtos $\mathbf{x}$ contém uma matriz de atributos: $\mathbf{a}=\mathbf{a}_{\mathrm{ij}}, \mathrm{i}=2, \ldots, \mathrm{I}$ e $\mathrm{j}=1, \ldots, \mathrm{J}$. Enquanto cada produto tem o mesmo conjunto de atributos associados a ele, a quantidade ou o nível de cada atributo é dependente do produto específico. Por exemplo, alguns produtos podem, relativamente, possuir grande quantidade de um atributo, enquanto, em outros, pode esse atributo estar ausente. O consumo de serviços é provido pelos produtos e seus respectivos atributos ${ }^{5}$.

onde:

$$
s_{k}=s_{k}\left(x_{1}, a_{1}, x, a\right), k=1, \ldots, K .(4)
$$

$\mathrm{s}_{\mathrm{k}}=$ serviço $\mathrm{k}$ oferecido pelo produto $\mathrm{x}_{1}$

$\mathrm{x}_{1}=$ produto analisado

$\mathbf{a}_{1}=$ vetor de atributos oferecido pelo produto $x_{1}$,

$\mathbf{x}=$ conjunto de produtos alternativos $a x_{1}$,

$\mathbf{a}=$ matriz do conjunto de atributos dos produtos alternativos $\mathbf{x}$

\footnotetext{
${ }^{54}$ Vetores e matrizes são expressos em negrito.

${ }^{55}$ Para um alimento, um atributo pode ser o nível de proteína, enquanto um exemplo de serviço pode ser o valor nutricional adicionado.
} 
A função utilidade, portanto, fica representada da seguinte maneira:

$$
\mathrm{U}=\mathrm{u}\left(\mathrm{s}_{1}, \ldots, \mathrm{s}_{\mathrm{k}}\right)(5)
$$

O consumidor maximizará a função utilidade $U$, sujeita à restrição orçamentária:

$$
\mathrm{p}_{1} \mathrm{x}_{1}+\mathbf{p}^{\prime} \mathbf{x} \leq \mathrm{m}(6)
$$

resultando na função demanda para $x_{1}$, isto é:

$$
\mathrm{x}_{1}=\mathrm{x}_{1}\left(\mathrm{p}_{1}, \mathrm{a}_{1}, \mathrm{p}, \mathrm{a}, \mathrm{m}\right)(7)
$$

Substituindo a função serviços (4) na função utilidade (5) e produtos na função serviço, obtemos a função utilidade indireta que será objeto deste estudo:

onde:

$$
\mathrm{V}=\mathrm{v}\left(\mathrm{p}_{1}, \mathbf{a}_{1}, \mathbf{p}, \mathbf{a}, \mathrm{m}\right)(8)
$$

$V=$ função utilidade indireta de $x_{1}$

$\mathrm{p}_{1}=$ preço do produto $\mathrm{x}_{1}$

$a_{1}=$ vetor de atributos oferecido pelo produto $x_{1}$,

$\mathbf{p}=$ preço dos produtos alternativos $a \mathrm{x}_{1}$,

$\mathbf{a}=$ matriz do conjunto de atributos dos produtos alternativos $\mathbf{x}$

$\mathrm{m}=$ renda do consumidor

Como se vê, a decisão de compra do consumidor é condicionada pelo nível de renda, pelos atributos que o produto possui, pelo preço do produto e pelos atributos e preços de todos os outros produtos. A Figura 21 mostra que o consumidor irá demandar o conjunto de atributos, no caso mecanismo forma e informal, que maximizará a sua utilidade através da sua curva de indiferença $I^{*}$, mais afastada da origem, que lhe proporciona a maior utilidade sujeita à sua restrição orçamentária, determinada pela renda e, conseqüentemente, pela fronteira de eficiência $^{56}$

Se a combinação $C$ se situa entre os dois produtos hipotéticos, o consumidor combinará uma quantidade de cada atributo para satisfazer a sua utilidade (DOUGLAS, 1992). Consumindo o produto hipotético $A$, até o ponto $D$, ele irá acumular a quantidade de $X_{1}$ do atributo mecanismo formal e $Y_{1}$ do atributo mecanismo informal. A partir do ponto $D$, ele começa a consumir o produto hipotético $B$, começando pelo ponto $E$ até alcançar a proporção C. A linha CD tem a mesma inclinação da reta representando o produto hipotético $B$ e, portanto, $C D=C E$. Portanto, a partir do ponto $D$, ele consome mais $Y_{2}-Y_{1}$ (de mecanismo formal) e $X_{2}-X_{1}$ (de mecanismo formal), atingindo o ponto $C$, maximizando sua utilidade.

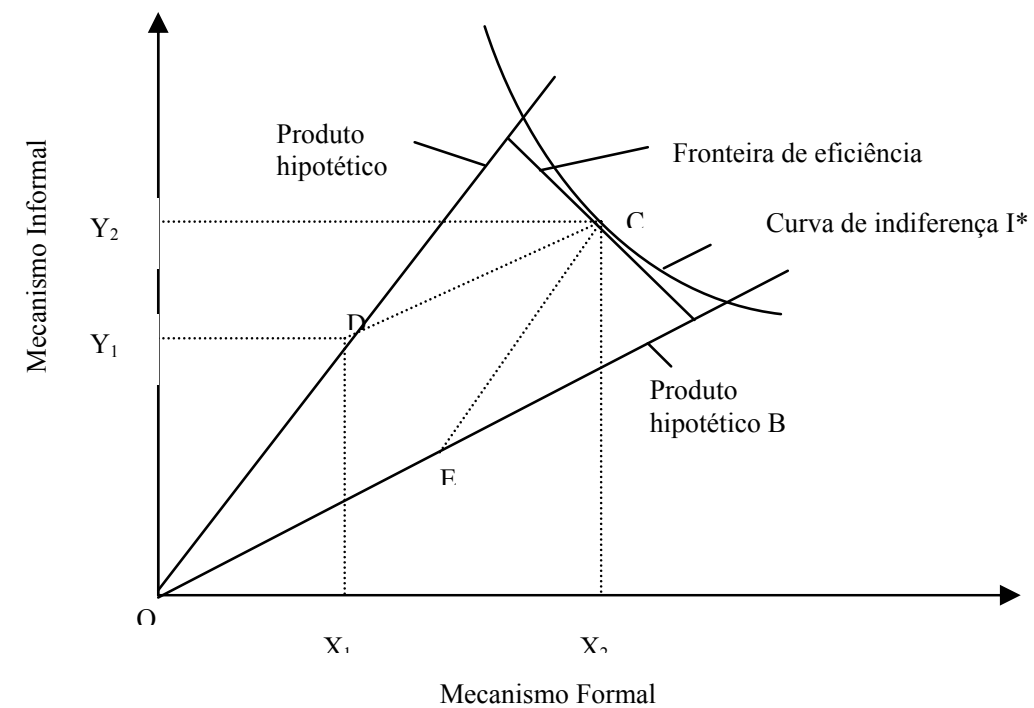

Figura 21. Maximização da utilidade por atributos

\footnotetext{
${ }^{56}$ É o limite mais distante atingível da combinação dos atributos desejável dada a restrição orçamentária.
} 